\title{
Genetic polymorphisms of the renin-angiotensin system : functional implications
}

Citation for published version (APA):

Spiering, W. (2004). Genetic polymorphisms of the renin-angiotensin system : functional implications. [Doctoral Thesis, Maastricht University]. Universiteit Maastricht. https://doi.org/10.26481/dis.20041112ws

Document status and date:

Published: 01/01/2004

DOI:

10.26481/dis.20041112ws

Document Version:

Publisher's PDF, also known as Version of record

\section{Please check the document version of this publication:}

- A submitted manuscript is the version of the article upon submission and before peer-review. There can be important differences between the submitted version and the official published version of record. People interested in the research are advised to contact the author for the final version of the publication, or visit the DOI to the publisher's website.

- The final author version and the galley proof are versions of the publication after peer review.

- The final published version features the final layout of the paper including the volume, issue and page numbers.

Link to publication

\footnotetext{
General rights rights.

- You may freely distribute the URL identifying the publication in the public portal. please follow below link for the End User Agreement:

www.umlib.nl/taverne-license

Take down policy

If you believe that this document breaches copyright please contact us at:

repository@maastrichtuniversity.nl

providing details and we will investigate your claim.
}

Copyright and moral rights for the publications made accessible in the public portal are retained by the authors and/or other copyright owners and it is a condition of accessing publications that users recognise and abide by the legal requirements associated with these

- Users may download and print one copy of any publication from the public portal for the purpose of private study or research.

- You may not further distribute the material or use it for any profit-making activity or commercial gain

If the publication is distributed under the terms of Article $25 \mathrm{fa}$ of the Dutch Copyright Act, indicated by the "Taverne" license above, 
Genetic polymorphisms of the renin-angiotensin system:

functional implications 
○ W. Spiering, Eindhoven 2004

ISBN 90-9018548-8

Coverdesign: A. Gericke, Datawyse

Production: Datawyse | Universitaire Pers Maastricht

Scientific studies in this thesis were supported by unrestricted research grants from Profileringsfonds, Academisch Ziekenhuis Maastricht and Merck Sharp \& Dohme B.V.

Printing of this thesis was financially supported by AstraZeneca B.V., Bayer B.V., Boehringer Ingelheim B.V., Bristol-Myers Squibb B.V., Menarini Farma Nederland B.V., Merck Sharp \& Dohme B.V., Novartis Pharma B.V., Novo Nordisk Farma B.V., Pfizer B.V., Servier Nederland B.V., SmithKline Beecham B.V., Yamanouchi Pharma B.V., and Zambon Nederland B.V. 


\section{Genetic polymorphisms of the renin-angiotensin system:}

functional implications

\section{Proefschrift}

ter verkrijging van de graad van doctor

aan de Universiteit Maastricht,

op gezag van de Rector Magnificus,

Prof.mr. G.P.M.F. Mols,

volgens het besluit van het College van Decanen,

in het openbaar te verdedigen

op vrijdag 12 november 2004 om 14.00 uur

door

Willem Spiering

geboren op 23 oktober 1971 te Arnhem 


\section{Promotor}

Prof.dr. P.W. de Leeuw

\section{Copromotor}

Dr. A.A. Kroon

\section{Beoordelingscommissie}

Prof.dr. H.A.J. Struijker Boudier (voorzitter)

Prof.dr. M.J.A.P. Daemen

Prof.dr. A.H.J. Danser (Erasmus Universiteit Rotterdam)

Prof.dr. G.J. Navis (Rijksuniversiteit Groningen)

Prof.dr. R.F.M. Vlietinck 
Neque enim disputari sine reprehensione potest.

Voor Helga 
Chapter 1 Outline of the thesis

Chapter 2 Genetics in hypertension

Chapter 3 Effects of the angiotensin-converting enzyme insertion/ deletion and angiotensin II type 1 receptor $\mathrm{A} 1166 \mathrm{C}$ polymorphisms on blood pressure in healthy normotensives

Chapter 4 Genetic influences on twenty-four hour blood pressure profiles in a hypertensive population

Chapter 5 Slow angiotensin-converting enzyme-related conversion of angiotensin I in plasma of hypertensive patients: relationship with the angiotensin-converting enzyme insertion/deletion polymorphism

Chapter 6 Genetic aspects of renal function in essential hypertension

Chapter 7 Angiotensin II sensitivity is associated with the angiotensin II type 1 receptor $A 1166 C$ polymorphism in essential hypertensives on a high sodium diet

Chapter 8 Genetic contribution to the acute effects of angiotensin II type 1 receptor blockade

Chapter 9 Genetic contribution to the chronic effects of angiotensin II type 1 receptor blockade

Chapter 10 General discussion

Summary 
Dankwoord

List of publications

Curriculum vitae 


\section{Abbreviations}

ABPM ambulatory blood pressure monitoring

ACE angiotensin-converting enzyme

ACTH adrenocorticotropic hormone

AGT angiotensinogen

AME apparent mineralocorticoid excess

Angl angiotensin I

Angll angiotensin II

ANOVA analysis of variance

ANP atrial natriuretic peptide

APRC active plasma renin concentration

ARR aldosterone-to-renin ratio

AT1R angiotensin II type 1 receptor

AT2R angiotensin II type 2 receptor

AT4R angiotensin II type 4 receptor

BMI body mass index

BPMD blood pressure modifying drug

DBP diastolic blood pressure

DMII diabetes mellitus type 2

DNA desoxy-ribonucleic acid

$\mathrm{ENaC}$ epithelial sodium channel

ERBF effective renal blood flow

ERPF effective renal plasma flow

FF filtration fraction

GRA glucocorticoid-remediable aldosteronism

GFR glomerular filtration rate

HR heart rate

I/D insertion/deletion

IQR interquartile range

MBP mean blood pressure

MR mineralocorticoid recepter

mRNA messenger ribonucleic acid

PAH para-aminohippurate

PCR polymerase chain reaction

PHAll pseudohypoaldosteronism type II

PP pulse pressure

QTL quantitative trait locus

RAOR recent African origin/replacement

RAS renin-angiotensin system

RIA radioimmunoassay 
RVR renal vascular resistance

SBP systolic blood pressure

SEM standard error of the mean

SNP single nucleotide polymorphism 


\section{Chapter 1}

Outline of the thesis 
Chapter 1 


\section{Outline of the thesis}

Essential hypertension is a common disorder, which affects $25-30 \%$ of the adult population, and up to $60-70 \%$ of those beyond the seventh decade of life.' Although seemingly symptomless it is in fact a silent killer, because it is by far the most important risk factor worldwide for total mortality. Its impact on the global burden of disease is higher than e.g. smoking, and alcohol. ${ }^{2}$

Although the clinical implications of hypertension are substantial our understanding of the disorder is strikingly low. The majority of patients with hypertension $(\approx 95 \%)$ suffers from primary or essential hypertension, which is an euphemism for not knowing the exact cause of the increased pressure. It is widely believed that essential hypertension is a multifactorial disorder caused by heterogeneous genetic and environmental factors. Hypertension aggregates with other cardiovascular risk factors, such as abdominal obesity, dyslipidemia, glucose intolerance, hyperinsulinemia, and hyperuricemia, possibly because of a common underlying cause. ${ }^{\prime}$

Already in 1831, Richard Bright stated that hypertension is a kidney disease. Accumulating evidence indeed shows that the kidney plays a central role in the pathophysiology of essential hypertension. Renal transplantation studies both in rats and in men, showed that transplantation of a kidney from a normotensive donor reduces the blood pressure in the recipient. ${ }^{3.4}$ Guyton and coworkers, in a series of neat experiments, showed that long-term blood pressure control is regulated by the pressure-natriuresis mechanism. Blood pressure rises when the kidney requires a higher than usual blood pressure to maintain extracellular fluid volume within normal limits. ${ }^{5}$ They demonstrated that in essential hypertension, pressure-natriuresis is abnormal because sodium excretion is the same as in normotension despite increased arterial pressure. Considerable evidence indicates that this resetting of the pressure-natriuresis curve plays a key role in causing hypertension, and is not merely an adaptation to increased blood pressure. Because human essential hypertension is a heterogeneous disease, it is likely that multiple neurohumoral and intrarenal defects contribute to abnormal pressure-natriuresis and increased blood pressure. ${ }^{6}$

The renin-angiotensin system (RAS) is the principal hormonal system that modulates both renal hemodynamics, i.e. glomerular filtration rate and renal blood flow, as well as tubular function. In this way the RAS both directly and indirectly regulates renal sodium handling. Secretion of renin is primarily regulated within the kidney by changes in either perfusion pressure or the delivery of sodium to the macula densa cells located in the distal tubules. Increased RAS activity shifts the pressure-natriuresis curve to the right, which can be reversed by blocking the RAS through angiotensin-converting enzyme (ACE) 
inhibition or angiotensin II type 1 receptor (AT1R) blockade. As in essential hypertension the pressure-natriuresis curve is also shifted to the right, it is tempting to assume that increased RAS activity is (at least partly) responsible for the increase in blood pressure in essential hypertension. ${ }^{7}$ However, increased RAS activity is not a pathognomonic finding in essential hypertension as both highrenin and low-renin forms of hypertension can be distinguished.

More and more evidence indicates that genetic factors play a prominent role in essential hypertension, and the molecular revolution has initiated an extensive search into these factors. This also was the major impetus for performing the studies which are described in this thesis. In chapter 2, the genetic aspects of both monogenic and essential hypertension are discussed. Furthermore, evolutionary aspects of blood pressure regulation are highlighted, as these are important to understand the contemporary epidemic outbreak of hypertension in the developed and developing world. Lastly, because of the central role of the RAS in blood pressure regulation, as indicated above, an overview of the RAS as we know it today, is presented. Since angiotensin II (AngII) is the effector hormone of the RAS, we were interested in polymorphisms that influence the generation and effect of this hormone. The mutant D allele of the ACE insertion/deletion (I/D) polymorphism is associated with higher circulating serum ACE levels ${ }^{8}$ and therefore, at least in theory, generates more Angll causing higher blood pressures and an increased incidence of cardiovascular disorders. ${ }^{\circ}$ On the other hand, the mutant C allele of the AT1R A1166C, polvmornhism is associated with a hjaher incidence of cardiovascular abnormalities ${ }^{10,11}$ and there is data to show that the interaction of Angll with the AT1R is altered due to this polymorphism. Taking these observations into account, our research has focused on the role of these polymorphisms in modulating the effects of Angll on the kidney and, indirectly, blood pressure. Chapter $\mathbf{3}$ addresses the effects of these polymorphisms on blood pressure in healthy normotensives. As this study indicated that at least the ACE I/D polymorphism is associated with higher blood pressures in normotensives, we then became interested in the role of these polymorphisms on blood pressure in a hypertensive population, which is discussed in chapter $\mathbf{4}$. Because phenotyping is very important in studying genotype-phenotype relationships, we chose to use high quality phenotyping of the blood pressure by means of 24 hour ambulatory blood pressure monitoring. In chapter $\mathbf{5}$ the conversion of Angl to Angll was studied to evaluate whether higher serum ACE levels in D allele carriers and their increased cardiovascular risk can be explained by increased Angll generation. Based on earlier studies which indicated that renal function is dependent upon both RAS activity ${ }^{12}$ and genetic factors, ${ }^{13}$ we set out to assess, as described in chapter 6, whether the ACE I/D and AT1R A1166C polymorphisms are associated with impaired renal function in essential hypertension. This is followed, in chapter 7 , by a study which investigated whether the AT1R A1166C polymorphism is associated with altered renal sensitivity to Angll. Because these studies indeed 
revealed an increased Angll sensitivity in C allele carriers, two pharmacogenetic studies were then initiated to study both the acute renal hemodynamic (Chapter 8) and long-term blood pressure (Chapter 9) effects of the AT1R antagonist losartan in relation to this polymorphism. Finally, in chapter 10, we summarize and discuss the different findings of our studies. 


\section{References}

1. Staessen JA, Wang J, Bianchi G, Birkenhager WH. Essential hypertension. Lancet 2003;361: 1629-41.

2. Ezzati M, Lopez AD, Rodgers A, Vander Hoorn S, Murray CJ. Selected major risk factors and global and regional burden of disease. Lancet 2002;360:1347-60.

3. Grisk O, Rettig R. Renal transplantation studies in genetic hypertension. News Physiol Sci 2001;16:262-5.

4. Guidi E, Menghetti D, Milani S, Montagnino G, Palazzi P, Bianchi G. Hypertension may be transplanted with the kidney in humans: a long-term historical prospective follow-up of recipients grafted with kidneys coming from donors with or without hypertension in their families. J Am Soc Nephrol 1996;7:1131-8.

5. Guyton AC. Long-term arterial pressure control: an analysis from animal experiments and computer and graphic models. Am J Physiol 1990;259:R865-77.

6. Hall JE, Guyton AC, Brands MW. Pressure-volume regulation in hypertension. Kidney Int Suppl 1996;55:S35-41.

7. Laragh J. Laragh's lessons in pathophysiology and clinical pearls for treating hypertension. Am J Hypertens 2001;14:186-94.

8. Rigat B, Hubert C, Alhenc-Gelas F, Cambien F, Corvol P, Soubrier F. An insertion/deletion polymorphism in the angiotensin I-converting enzyme gene accounting for half the variance of serum enzyme levels. J Clin Invest 1990;86:1343-6.

9. Tiret L, Bonnardeaux A, Poirier O, Ricard S, Marques-Vidal P, Evans A, Arveiler D, Luc G, Kee F, Ducimetiere P, et al. Synergistic effects of angiotensin-converting enzyme and angiotensin-II type 1 receptor gene polymorphisms on risk of myocardial infarction. Lancet 1994;344:910-3.

10. Bonnardeaux A, Davies E, Jeunemaitre X, Fery I, Charru A, Clauser E, Tiret L, Cambien F, Corvol P, Soubrier F. Angiotensin II type 1 receptor gene polymorphisms in human essential hypertension. Hypertension 1994;24:63-9.

11. Benetos A, Topouchian J, Ricard S, Gautier S, Bonnardeaux A, Asmar R, Poirier O, Soubrier F, Safar $\mathrm{M}$, Cambien F. Influence of angiotensin II type 1 receptor polymorphism on aortic stiffness in never-treated hypertensive patients. Hypertension 1995;26:44-7.

12. Hollenberg NK, Williams GH, Burger B, Ishikawa I, Adams DF. Blockade and stimulation of renal, adrenal, and vascular angiotensin II receptors with 1-Sar, 8-Ala angiotensin II in normal man. J Clin Invest 1976;57:39-46.

13. van Hooft IM, Grobbee DE, Derkx FH, de Leeuw PW, Schalekamp MA, Hofman A. Renal hemodynamics and the renin-angiotensin-aldosterone system in normotensive subjects with hypertensive and normotensive parents. N Engl J Med 1991;324:1305-11. 


\section{Chapter 2}

\section{Genetics in hypertension}

Wilko Spiering, Abraham A. Kroon, Peter W. de Leeuw To be published in Sem Vasc Med 
Chapter 2 


\section{Introduction}

In developed and developing countries, hypertension affects $25-30 \%$ of the adult population, and up to $60-70 \%$ of those beyond the seventh decade of life.' It is by far the most important risk factor for total mortality. ${ }^{2}$ It is now widely recognized that hypertension is a multifactorial trait caused by a complex combination of demographic, environmental, and genetic factors. ${ }^{3}$

There is substantial evidence for genetic influences on blood pressure. For instance twin studies documented greater concordance of blood pressures of monozygotic than dizygotic twins, ${ }^{4}$ and population studies demonstrate greater similarity of blood pressure within families than between families. ${ }^{5}$ This familial aggregation of blood pressure is not simply attributable to shared environmental factors since adoption studies show greater concordance of blood pressure among biological siblings than adoptive siblings living in the same household. ${ }^{6,7}$ Genetic heritability in blood pressure resemblances varies between $25 \%$ in pedigree studies to $65 \%$ in twin studies..$^{7-9}$ Nevertheless, part of the familial concordance can be explained by a shared environment, mostly dietary in nature. ${ }^{10}$ Finally, single genes can impart large effects on blood pressure as demonstrated by rare Mendelian forms of high and low blood pressure."1

The inheritance of hypertension has been debated for many years ever since Pickering and Platt clashed over the distribution of blood pressure in the population. Pickering argued that blood pressure, like other traits such as height or weight, was continuously distributed ${ }^{12}$ whereas Platt believed that the distribution was bimodal. ${ }^{13}$ Their views implied rather different inheritance mechanisms: on the one hand multiple genes and on the other a single (or major) gene controlling blood pressure. Pickering's polygenic model for blood pressure in the general population has now been widely accepted. Indeed, the model of multiple susceptibility genes with environmental interaction is one that can be applied to many common complex diseases including asthma, diabetes and ischemic heart disease. However, there are still some familial forms of hypertension which are inherited as single-gene disorders, but they constitute only a small proportion of all cases.

Although it is not well known which genes influence blood pressure variability between individuals, family studies show that the 'inherited part' of blood pressure ranges over the whole spectrum from low-normal blood pressure to severe hypertension. Next to this, 'hypertensinogenic' factors like obesitas, insulin resistance, alcohol, salt, etc. play a role. The actual blood pressure of a subject is the sum of a more or less fixed, inherited part and a more variable part that is influenced by the hypertensinogenic factors. 
Besides the independent effects of genetic and environmental factors on blood pressure height, interactions between these factors are present. The outcome of these effects influences intermediate phenotypes, like sympathetic activity, the renin-angiotensin system (RAS), the kallikrein-kinin system, endothelial factors, etc. These phenotypes influence, on their turn, other intermediate phenotypes like sodium-excretion, vascular reactivity and cardial contractility. The sum of these and many other intermediate phenotypes in the end defines total peripheral resistance and cardiac output and as a resultant the actual blood pressure (Figure 2.1). If we assume that every intermediate phenotype influencing blood pressure is by itself dependent upon one or more genes, one can see the enormous amount of genes involved in blood pressure regulation.

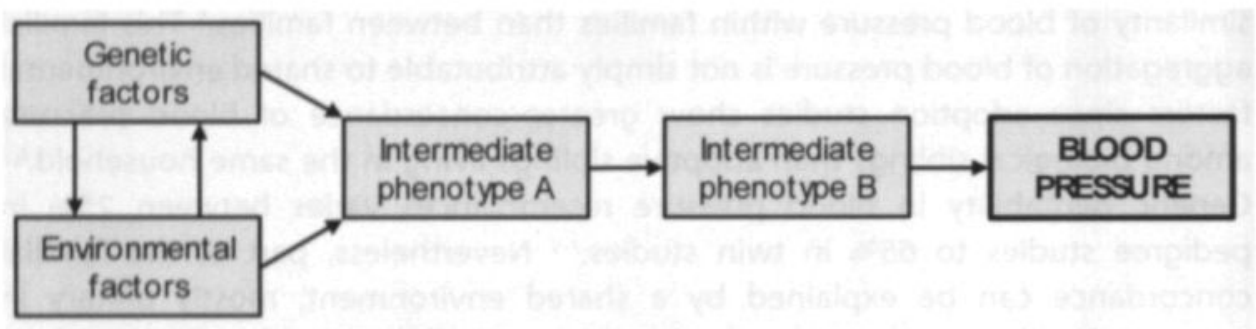

Figure 2.1. Factors influencing blood pressure.

\section{Evolutionary aspects}

The common disease:common variant hypothesis speculates that the gene variation underlying susceptibility to common heritable diseases existed within the founding population of contemporary humans.3.14,15 As this population expanded outwards from Africa, the ancient gene variation of these founders has been distributed globally. The disease susceptibility alleles included among this variation have persisted at moderate frequency, presumably because they have been neutral during the natural selection process, at least until the recent appearance of technological advancements creating the environment required for disease manifestation. This hypothesis is supported by evidence that the modern global population is the progeny of a recent $(\approx 100,000$ years) dispersal of a single sub-Saharan African founding population of relatively small size that replaced all other hominoids. The strongest genetic evidence in favor of this recent African origin/replacement (RAOR) scenario arises from studies of sequence variation in the mitochondrial DNA and in the non-recombining region of the $Y$ chromosome (NRY). Mitochondrial DNA reflects a matrilineal inheritance, whereas the NRY reflects a patrilineal inheritance. Investigation of both mitochondrial DNA and NRY variation indicates a single phylogenetic tree down which contemporary 
humans descended from common ancestors in Africa about 35 to 200,000 years ago. ${ }^{16,17}$ Because these 2 sources reflect separate genetic lineages, concordance between them has provided high credibility for the RAOR model of contemporary human origins. ${ }^{14}$ Estimates of the effective size of the ancestral population from which contemporary humans are descended indicate a number of about $10,000.18,19$ This relatively small number fits well in the common disease:common variant hypothesis, because recent expansion of the human population to its current size of 6 billion from a small group of founders implies substantial sharing of alleles, including those responsible for common diseases. ${ }^{14}$

Already forty years ago, Neel hypothesized that common complex genetic diseases of 'civilization' including obesity, hypertension, and diabetes type 2 (DMII) result from the exposure of a thrifty genotype to a prodigal environment. ${ }^{20}$ According to this concept, diseases of civilization result from a discordance between certain features of our present-day environment and our genetic makeup which evolved over time to fit the life of Paleolithic humans. This lifestyle involved a great deal of physical activity and a diet high in protein and potassium and low in fat and sodium. Due to the irregular availability of food, short periods of feast alternated with relatively longer periods of hunger. It is possible that many metabolic features of modern humans originally evolved as adaptation to such a lifestyle, and these features are now etiologic to modern diseases such as obesity, hypertension, and DMII. Thus, individuals who are genetically predisposed to low metabolic rates, sodium conservation, and rapid mobilization of insulin in response to a carbohydrate challenge would be genetically predisposed to obesity, salt-sensitive hypertension, and DMII when faced with a sedentary lifestyle and a high salt, energy-dense diet.

The cultural changes that have occurred over the past 10,000 years have far outpaced any possible genetic adaptations, especially since much of this cultural change has occurred only recently following to the first industrial revolution 200 years ago.21 The extremely slow pace of genetic evolution is revealed by biomolecular evidence indicating that humans and chimpanzees differ genetically by only $1.6 \%$, even though the hominoid-pongoid divergence occurred 7 million years ago. 22 If we assume that present-day hominoids are still faced with the same selection pressures that applied to humans during the many millennia of evolution, there are good reasons to believe that the genes relevant to the thrifty genotype are highly conserved in these species and probably represent the 'original version' of these genes common to early hominoids. Thus, individuals or populations in whom a large proportion of these ancestral thrifty genes remains conserved are more likely to express the disease phenotype on exposure to a rich environment than individuals or populations in whom less thrifty variants of these genes have recently developed. ${ }^{23}$ The idea of the thrifty genotype has substantial implications on our approach towards understanding and studying the genetic basis of these complex diseases. Currently, most investigators are attempting to 
find the mutations or genetic defects responsible for obesity, hypertension, or DMII. The thrifty-genotype hypothesis, however, implies that the genetic basis for these diseases is not to be found in recent mutations or genetic defects but rather lies in the conservation of the ancestral version of the relevant genes. Thus, while the original version of the thrifty genotype may confer increased susceptibility to hypertension or obesity, recent mutations resulting in a loss of thriftiness would protect the carrier from the deleterious effects of the current Western diet, rich in carbohydrates and salt. A fine example of this principle was recently provided by the study of the angiotensinogen (AGT) gene in hypertension. Jeunemaitre et al. reported a genetic variant of this gene, involving the substitution of threonine (T) for methionine $(\mathrm{M})$ at codon 235 , to be more common in hypertensives than in normotensive controls. ${ }^{24}$ Assuming that the rarer $T$ allele associated with hypertension was the novel form, they termed this variant M235T, suggesting that $M$ is the ancestral allele and $T$ the mutation. However, subsequent studies in Japanese $\mathrm{e}^{25}$ and African-Americans ${ }^{26}$ have revealed that this mutation is much more common in these populations than in whites, and other investigators have found this variant to be even more common in Nigerians, in whom it approaches a frequency above $90 \% .{ }^{27}$ Since the ancestors of present-day whites are believed to have migrated from Africa, it soon became apparent that the $T$ at codon 235 , associated with hypertension, is the wild type whereas the $M$ allele, associated with normotension, is the recent mutant. This idea was further supported by the demonstration that the $T$ at codon 235 is present in a variety of primates, including man's closest relative, the chimpanzee. ${ }^{28}$ This would indeed be in line with the concept that the original phylogenetically ancestral version of the AGT gene is associated with hypertension, whereas the recent mutation somehow decreases the risk for developing high blood pressure. It does not seem illogical to assume that this concept also holds for the many other genes involved in hypertension.

\section{Genetic studies in hypertension}

Three different approaches have been executed to investigate the genetic factors that contribute to hypertension: studies on rare genetic syndromes, linkage studies, and association studies.

\section{Studies on rare genetic syndromes}

With positional cloning disease genes are located using genome mapping techniques with only minimal information about the function of the gene or the basic biochemical defect. It uses genome-wide scans and linkage analyses in families affected with a disease to define an initial candidate region, which then may be narrowed considerably using fine mapping techniques. Screening for 
mutations in affected individuals may pinpoint the causative gene. With this method the causative mutations that underlie several monogenic or Mendelian disorders were identified. The advantage of this approach is that when a positive result is obtained, it provides an unambiguous explanation of the cause of the syndrome under investigation and often yields basic insights into pathophysiology. While the number of individuals with these syndromes will always be small, the implications of the findings can apply to much larger groups.

\section{Linkage studies}

In linkage studies statistical methods are used to locate genes contributing to disease or other phenotypes to approximate chromosomal regions. Genetic linkage analysis exploits the tendency of short chromosomal segments to be inherited intact from parents to offspring. This means that if a marker locus and a trait-influencing locus are physically close on a chromosome, the probability of a recombination event occurring between them during meiosis is low, and the two loci tend to be inherited together more often than would be expected from independent segregation. Genome-wide linkage analyses have identified chromosomal regions that influence interindividual variation in blood pressure levels or risk for essential hypertension on almost all different chromosomes (Table 2.1). Especially chromosomes 2, 3, 7, 15 and 17 repeatedly showed evidence for linkage with hypertension. Nevertheless, the specific genes and gene variations responsible for the observed effects remain to be identified. Candidate gene linkage analyses, in which the linkage of candidate genes with a specific phenotype is studied, have suggested that the genes for AGT, ${ }^{24} \alpha$-adducin, ${ }^{29}$ angiotensin-converting enzyme $(\mathrm{ACE}),{ }^{30,31}$ and angiotensin $\|$ type 1 receptor $(A T 1 R)^{32}$ are involved in the pathogenesis of essential hypertension.

\section{Association studies}

Once their chromosomal position has been determined by linkage studies, association (or case-control) studies are used for identifying genes implicated in specific phenotypes. These are well suited to genetic studies of complex traits because they can detect weak-to-moderate effects of genes on a trait. ${ }^{33}$ Association methods test for differences in allele frequencies at a marker locus between groups of individuals (e.g., cases and controls) to implicate specific alleles of that locus in contributing to a specific phenotype. True association between a marker locus and a disease locus may arise for two reasons: 1) the marker itself directly contributes to the disease; and 2) alleles at the marker locus are in linkage disequilibrium with alleles at the disease locus. Linkage disequilibrium is said to be present when certain haplotypes (i.e., linear arrangement of alleles at different loci on the same chromosome) occur more frequently in a population than would be expected by chance, based on the 
assumption of independent occurrence of alleles at each locus. Loose linkage between two loci will not result in an association in the population because recombination will occur with a sufficiently high frequency in the population to return alleles quickly to equilibrium. However, for tightly linked loci, linkage disequilibrium can persist over many generations, when one assumes a low mutation rate of both loci. The present-day population reflects the action of recombination through many past generations, and linkage disequilibrium mapping seeks to take advantage of this historical recombination to localize genes that influence traits of interest.

Table 2.1. Chromosomes linked to interindividual blood pressure variations or risk for essential hypertension.

\begin{tabular}{|c|l|}
\hline Chromosome & Reference(s) \\
\hline 1 & $196-198$ \\
2 & $198-204$ \\
3 & $200,201,205,206$ \\
5 & 198,201 \\
6 & 197,207 \\
7 & $197,198,201,208$ \\
8 & 198 \\
10 & 201 \\
11 & 200,206 \\
12 & 197,200 \\
14 & 199 \\
15 & $197,206,209,210$ \\
16 & 206 \\
17 & $70-72,206$ \\
18 & 70,211 \\
19 & $198,200,201$ \\
\hline
\end{tabular}

\section{Polymorphisms}

Approximately $90 \%$ of all variations in the human genome occur as single base pair substitutions. ${ }^{34}$ These single nucleotide polymorphisms (SNPs) by definition have a minor allele frequency greater than $1 \%$. This variation arises through a single mutation event in the history of the population. SNPs, as well as the less frequently occurring insertions and deletions, generally have two alleles in the population at large. Although in theory more than one substitution could occur at any single nucleotide, resulting in the formation of more than two alleles, the probability of such an event is extremely low. Consequently, SNPs are often considered and referred to as di (or bi)-allelic markers, representing the ancestral or wild type and the (mutant) variant form. The average number of nucleotide differences between a random pair of chromosomes drawn from the population is 
estimated at $1 / 1000$ base pairs. ${ }^{35,36}$ However, this estimate is likely to vary considerably across the genome. Indeed, a lower frequency of polymorphism is observed in coding regions (exons) versus non-coding regions (introns). This is presumably because of the effect of selection pressure to remove disadvantageous alleles. The majority of DNA sequence variations between human individuals is represented within populations. ${ }^{37}$ Comparisons among populations result in the addition of only a fractional increase in SNP diversity, although allele frequencies may differ across populations. This pattern reflects the fact that all human populations share a relatively recent common genetic heritage and that most common variation arose before the expansion of the human species into distinct contemporary populations.

\section{Mendelian forms of hypertension}

Molecular genetic studies have identified mutations in several genes in 6 Mendelian forms of hypertension (Table 2.2). These genes typically impart very large effects on blood pressure. Given the diversity of physiologic systems that affect blood pressure, it is perhaps surprising that the mutated gene products in almost all cases act in the same physiologic pathway in the kidney: altering net renal salt reabsorption. Each of these conditions features salt sensitivity with increased sodium and volume reabsorption by the kidney and low plasma renin activity. Furthermore, Mendelian forms of hypotension (e.g., Gitelman and Bartter syndrome) have been identified that increased our knowledge of blood pressure regulation. These syndromes will not be discussed here.

\section{Glucocorticoid-remediable aldosteronism}

Glucocorticoid-remediable aldosteronism (GRA) is an autosomal dominant trait, featuring early onset of hypertension with normal or elevated aldosterone levels despite suppressed plasma renin activity. ${ }^{38}$ Hypokalemia and metabolic alkalosis are variable associated findings, ${ }^{39}$ although normokalemia as a typical finding is also reported..$^{40}$ High levels of the abnormal adrenal steroids 18 -oxocortisol and 18-hydroxycortisol are a pathognomonic finding. The hallmark of this disease, however, is that exogenous glucocorticoids completely suppress aldosterone secretion.

GRA is caused by a gene duplication arising by unequal crossing over between two closely related genes involved in adrenal steroid biosynthesis. These genes encode aldosterone synthase (the rate limiting enzyme for aldosterone biosynthesis in adrenal glomerulosa) and steroid 11 -hydroxylase, an enzyme involved in cortisol biosynthesis, in the adrenal fasciculata where their expression is regulated by adrenocorticotropic hormone (ACTH).41,42 The resulting chimeric gene encodes a protein with aldosterone synthase enzymatic activity, of which 
the expression is regulated by $\mathrm{ACTH}$. Aldosterone synthase activity is thus expressed ectopically in the adrenal fasciculata under control of ACTH rather than angiotensin II (Angll), its normal hormonal regulator. As a consequence, aldosterone secretion becomes inexorably linked to cortisol secretion, and maintenance of normal cortisol levels results in constitutive aldosterone secretion, which leads to an expanded plasma volume, hypertension, and suppression of renin. Moreover, the increased lumen-negative potential resulting from increased electrogenic $\mathrm{Na}^{+}$reabsorption increases the driving force for secretion of $\mathrm{K}^{+}$and $\mathrm{H}^{+}$, accounting for the development of hypokalemia and metabolic alkalosis.

Table 2.2. Monogenic forms of hypertension.

\begin{tabular}{|c|c|c|c|}
\hline Syndrome & Phenotype & Mutation & Mechanism \\
\hline $\begin{array}{l}\text { Glucocorticoid remediable } \\
\text { aldosteronism (GRA) }\end{array}$ & $\begin{array}{l}\text { HT, } K \cdot \downarrow \text {, alkalosis, } \\
\text { PRA } \downarrow \text {, aldo } \\
\text { suppressible by } \\
\text { dexamethasone }\end{array}$ & $\begin{array}{l}\text { Chimerical gene } \\
\text { containing promoter } \\
\text { area of aldo-synthase } \\
\text { and coding region } \\
11 \beta \mathrm{H} \text { (dominant) }\end{array}$ & $\begin{array}{l}\text { Chimerical enzyme } \\
\text { regulated by ACTH }\end{array}$ \\
\hline $\begin{array}{l}\text { Apparent mineralocorticoid } \\
\text { excess (AME) }\end{array}$ & $\begin{array}{l}\text { HT, K॰ } \downarrow \text {, aldo } \downarrow \text {, } \\
\text { alkalosis, PRA } \downarrow \text {, } \\
\text { suppressible by } \\
\text { spironolactone }\end{array}$ & $\begin{array}{l}\text { Absence of } 11 \beta \mathrm{HSD} \\
\text { (recessive) }\end{array}$ & $\begin{array}{l}\text { Impaired conversion } \\
\text { of cortisol (activates } \\
\text { MR) to cortisone } \\
\text { (inactive at MR) }\end{array}$ \\
\hline $\begin{array}{l}\text { Hypertension exacerbated by } \\
\text { progonany }\end{array}$ & $\begin{array}{l}\mathrm{HT}, \mathrm{K} \cdot \downarrow \text {, aldo } \downarrow \text {, } \\
\text { aikaiusis, nof } \downarrow\end{array}$ & $\begin{array}{l}\text { Missense mutation } \\
\text { mineraiocorticoid } \\
\text { receptor (dominant) }\end{array}$ & $\begin{array}{l}\text { Steroids without } 21 \text { - } \\
\text { nydroxyi group } \\
\text { (progesterone) and } \\
\text { spironolactone } \\
\text { stimulate mutant } \\
\text { mineralocorticoid } \\
\text { receptor }\end{array}$ \\
\hline Liddle syndrome & $\begin{array}{l}\text { HT, K+ } \downarrow \text {, aldo } \downarrow \text {, } \\
\text { alkalosis, PRA } \downarrow\end{array}$ & $\begin{array}{l}\text { Mutations of } \beta \text { or } \gamma \\
\text { subunit of } \mathrm{ENaC} \\
\text { (dominant) }\end{array}$ & $\begin{array}{l}\text { Increased } \mathrm{ENaC} \\
\text { activity due to } \\
\text { reduced } \mathrm{ENaC} \\
\text { clearance }\end{array}$ \\
\hline $\begin{array}{l}\text { Pseudohypoaldosteronism } \\
\text { type } 2 \text { (Gordon's syndrome) }\end{array}$ & $\begin{array}{l}\mathrm{HT}, \mathrm{K}+\uparrow, \mathrm{PRA} \downarrow \text {, } \\
\text { normal renal } \\
\text { function }\end{array}$ & $\begin{array}{l}\text { Mutations in either of } \\
\text { WNK1 or WNK4 } \\
\text { (dominant) }\end{array}$ & $\begin{array}{l}\text { Volume-expanded } \\
\text { HT, probably due to } \\
\text { increased renal } \\
\text { tubular sodium } \\
\text { reabsorption }\end{array}$ \\
\hline $\begin{array}{l}\text { Hypertension with } \\
\text { brachydactyly }\end{array}$ & HT, brachydactyly & $\begin{array}{l}\text { Genes mapped to } \\
12 \mathrm{p} 11.2-12.2 \\
\text { (dominant) }\end{array}$ & Unknown \\
\hline
\end{tabular}

$\mathrm{HT}$ : hypertension; PRA: plasma renin activity; aldo: aldosterone; ENaC: epithelial sodium channel; WNK1/4: serine-threonine kinase 'with no lysine' type 1/4; MR: mineralocorticoid receptor

A wide range of blood pressure levels (including normotension) is found in affected GRA subjects. ${ }^{40}$ However, these differences are not related to environmental factors such as sodium intake or differences in steroid levels. It is 
hypothesized that chimeric gene expression is variable, with low blood pressure subjects having reduced gene expression. Furthermore, it is likely that the wide range in blood pressure levels in affected subjects involves interaction of other systems which control blood pressure. This hypothesis is supported by studies in two kindreds suggesting that blood pressure levels are reciprocally related to levels of urinary kallikrein excretion..$^{40}$

\section{Syndrome of apparent mineralocorticoid excess}

Patients with the apparent mineralocorticoid excess (AME) syndrome have the same phenotypical findings as patients consuming large amounts of licorice: volume expansion, low renin, low aldosterone, salt-sensitive (early onset) hypertension, with sometimes metabolic alkalosis and hypokalemia. No abnormal urinary steroid metabolites can be found. The hypertension can be well treated with thiazide diuretics, or spironolactone. As aldosterone is low or sometimes even undectable the response to the mineralocorticoid receptor (MR) antagonist spironolactone suggests the presence of another circulating mineralocorticoid. ${ }^{43}$ While biochemical investigation failed to identify an abnormal steroid in the circulation, affected patients showed impaired conversion of cortisol to cortisone due to absence of the enzyme $11 \beta$-hydroxysteroid dehydrogenase (11ßHSD).44 The significance of this finding remained obscure until the cloning of the MR.45 In vivo, cortisol circulates at concentrations up to 1000-fold higher than aldosterone, but almost all MR activation in vivo is mediated by aldosterone. However, the specificity of the MR for aldosterone in vivo is mediated indirectly by $11 \beta \mathrm{HSD}$ which 'protects' the MR from cortisol by metabolizing it to cortisone, which does not activate the MR. ${ }^{46,47}$ In AME, the absence of this enzyme allows cortisol to activate the MR, resulting in hypertension mediated by increased epithelial sodium channel (ENaC) activity. Confirmation of the pathogenesis of AME came with the cloning of $11 \beta \mathrm{HSD}-2$. This gene, expressed in the same cells of the nephron that express $\mathrm{ENaC}$, shows homozygous loss-of-function mutations in AME patients. ${ }^{48}$

These findings explain the pathogenesis of hypertension in AME. Chronic ingestion of large quantities of natural licorice results in hypertension with suppressed renin and aldosterone due to the action of a licorice metabolite, glycerrhetinic acid. ${ }^{47}$ This compound is a potent inhibitor of $11 \beta \mathrm{HSD}$, producing a phenocopy of AME. Similarly, overproduction of cortisol due to adenomas of the adrenal or pituitary glands, or due to inherited loss of the glucocorticoid receptor $^{49}$ is also complicated by hypertension associated with low renin and aldosterone levels. The hypertension in these settings may be explained by the high circulating cortisol levels outstripping the ability of $11 \beta \mathrm{HSD}$ to convert cortisol to cortisone, resulting in cortisol-mediated activation of the MR. 


\section{Hypertension exacerbated in pregnancy}

A mutation in the ligand binding domain of the MR causes an autosomal dominant form of hypertension that is markedly accelerated in pregnancy..$^{50}$ The missense mutation, MR S810L, was found in a single patient during a systematic screen of the MR in patients with early onset hypertension. Examination of the patient's family demonstrated that $810 \mathrm{~L}$ carriers all developed hypertension before age 20, a finding absent among their wild-type relatives. Biochemical investigation of the mutant receptor demonstrated partial activation in the absence of added steroid, but otherwise normal activation by aldosterone. Surprisingly, however, compounds that normally bind, but do not activate the MR are all potent agonists of the mutant receptor. This includes steroids lacking 21hydroxyl groups, such as progesterone, and clinically used antagonists of the MR, such as spironolactone. Since progesterone levels rise 100-fold during pregnancy, this observation suggested that patients harboring $810 \mathrm{~L}$ might develop severe hypertension in pregnancy. Indeed, all pregnancies among patients harboring this mutation have been complicated by dramatic acceleration of hypertension associated with complete suppression of the RAS. ${ }^{50}$

The mechanism by which $810 \mathrm{~L}$ allows MR activation by steroids lacking 21 hydroxyl groups has been examined by molecular modeling and site-directed mutagenesis. The results demonstrate that the $810 \mathrm{~L}$ residue in helix 5 of the ligand binding domain makes a new Van der Waals interaction with A773 in helix 3 , and that this interaction eliminates the requirement for the 21-hydroxyl group of aldosterone to interact with N770 in helix 3 . This helix 5-helix 3 interaction is highly conserved among diverse nuclear hormone receptors, suggesting its general role in receptor activation. ${ }^{50}$

\section{Liddle syndrome}

Liddle syndrome is characterized by autosomal dominant transmission of early onset hypertension associated with hypokalemic alkalosis, suppressed plasma renin activity, and low plasma aldosterone levels. Patients do not respond to spironolactone, but are well treatable with thiazide diuretics and triamterene.

The disease is caused by mutations in either the $\beta$ or the $\gamma$ subunit of the amiloride- and triamterene-sensitive $\mathrm{ENaC}$ that delete their cytoplasmic C termini. ${ }^{51.52}$ These mutations result in increased $\mathrm{ENaC}$ activity, ${ }^{53}$ largely attributable to an increase in the number of channels at the cell surface. ${ }^{54}$ Rare missense mutations in patients identified a segment in the C termini, PPPXY, that when mutated gave the same phenotype. ${ }^{55,56}$ Systematic site-directed mutagenesis of channel subunits indicates that mutations of any of these residues yields an increased number of channels at the cell surface and hence, increased channel activity. ${ }^{57}$ The increased number of channels is due to reduced clearance of ENaC from the cell surface with a dramatically longer half-life. ${ }^{58}$ 
Two lines of inquiry have suggested mechanisms for the prolonged half-life of mutant channels. Inhibition of endocytosis via clathrin-coated pits by dominantnegative dynamin induces a phenocopy of the electrophysiologic phenotype of Liddle syndrome, increasing $\mathrm{Na}^{+}$current by markedly prolonging the half-life of $\mathrm{ENaC}$ at the cell surface..$^{58}$ In parallel, two WW domain-containing proteins, Nedd4$1^{59}$ and Nedd4-260 have been identified that specifically interact with the PPPXY sequence of $\mathrm{ENaC}$ subunits. These proteins have ubiquitin ligase domains, suggesting that interaction with $\mathrm{ENaC}$ subunits leads to their ubiquitination, targeting $\mathrm{ENaC}$ for degradation. Consistent with this proposal, expression of dominant-negative Xenopus ${ }^{61}$ or mammalian Nedd4-2, ${ }^{60}$ containing the WW domain without the ubiquitin ligase domain, also prolongs the half-life of wildtype $\mathrm{ENaC}$. These findings indicate that an increased number of $\mathrm{ENaC}$ at the cell surface is sufficient to produce hypertension in humans.

\section{Pseudohypoaldosteronism type II}

Pseudohypoaldosteronism type II (PHAII), also known as Gordon hyperkalemiahypertension syndrome, is an autosomal dominant disease featuring hypertension with hyperkalemia despite normal glomerular filtration rate. Mild hyperchloremia, renal tubular acidosis, and suppressed plasma renin activity are variable associated findings. The clinical features of this disease are chloride dependent and completely corrected with thiazide diuretics, specific antagonists of the $\mathrm{Na}-\mathrm{Cl}$ cotransporter (NCCT) of the distal convoluted tubule..$^{62-64}$

After this syndrome had been mapped to chromosome 1q31-42, 12p13, and $17 p 11-q 21,65,66$ it was shown that PHAll is caused by mutations in either of two serine-threonine kinases, WNK1 and WNK4 (WNK: with $\boldsymbol{m o}$ lysine $(\boldsymbol{K})$ at a key catalytic residue). PHAll-causing mutations in WNK1 are large deletions in the first intron of the gene that appear to increase WNK1 expression. Mutations in WNK4 are missense mutations in highly conserved segments remote from the kinase domain. ${ }^{67}$

Both kinases are present in the kidney, with their expression being confined to the distal convoluted tubule, connecting tubule, and collecting duct. These nephron segments are known to play a key role in the regulation of salt, $\mathrm{K}^{+}$, and $\mathrm{pH}$ homeostasis.67 These findings implicate WNK1 and WNK4 in a previously unrecognized signaling pathway that regulates the balance between $\mathrm{Cl}$ reabsorption versus $\mathrm{K}^{+}$and $\mathrm{H}^{+}$secretion.

The $\mathrm{Cl}$ dependence of PHAll phenotypes, their sensitivity to thiazide diuretics, and the observation that they constitute a 'mirror image' of the phenotypes resulting from loss-of-function mutations in the thiazide-sensitive NCCT causing Gitelman's syndrome, ${ }^{68}$ suggest that PHAll could result from increased activity of the NCCT due either to loss of normal inhibition or constitutive activation by mutant WNK kinases. Wild-type WNK4 inhibits NCCT-mediated $\mathrm{Na}^{+}$-influx by reducing 
membrane expression of the cotransporter and WNK4 mutations found in patients with PHAll abrogate this inhibitory function. ${ }^{69}$

Linkage of PHAll to chromosome 1 in other families ${ }^{65}$ as well as the absence of mutations in WNK1 and WNK4 in many PHAll kindreds indicate that there must be one or more yet unidentified PHAll genes.

Like patients with PHAll, many individuals with common, essential hypertension have low plasma renin activity and respond well to thiazide diuretics, raising the possibility that variants in WNK1 and WNK4 may underlie blood pressure variation in the general population. Indeed, the WNK4 gene lies only $1 \mathrm{Mb}$ from locus D17S1299, the site showing the strongest linkage to blood pressure variation in the Framingham Heart Study population. ${ }^{70}$ This same chromosome segment has suggested linkage to hypertension in two other studies. ${ }^{71,72}$ It will be of interest to determine whether variants that alter WNK4 function account for this linkage.

\section{Hypertension with brachydactyly}

In 1973, Bilginturan described a Turkish family that suffered from brachydactyly (type E) and severe hypertension. ${ }^{73}$ The inheritance is autosomal dominant with $100 \%$ co-segregation of both phenotypes. The condition resembles essential hypertension. Renin, aldosterone, and norepinephrine responses are normal and no salt sensitivity is present. ${ }^{74}$ The response to antihypertensive drugs is unremarkable. ${ }^{75}$ Another feature is diminished baroreflex sensitivity with markedly impaired blood pressure buffering. ${ }^{76}$ Furthermore, the ventrolateral medulla may be compromised in these patients, because neurovascular anomalies are a regular finding. ${ }^{77}$ The gene(s) for this disease are mapped to chromosome 12p11.2-12.2..$^{78}$ Interestingly, the same locus was recently mapped in Chinese families with essential hypertension. ${ }^{79}$ The 3 -centimorgan region contains three candidate genes: the ATP-dependent potassium channel Kir6.1, its regulator the sulfonyl urea receptor SUR2, and the phosphodiesterase PDE3A. ${ }^{80}$ Screening of the coding regions revealed that none of these candidate genes harbor obvious mutations. ${ }^{81}$ Gene expression and physiological studies did not yield convincing results as well, making these genes unlikely to be the causative ones..$^{80}$ Affected subjects show a rearrangement on chromosome $12 \mathrm{p}$. The rearrangement is complex in that a deletion, reinsertion, and inversion have occurred. ${ }^{80}$ These findings indicate that probably more than one gene is responsible for the complex phenotype.

\section{Other monogenic syndromes}

Besides the syndromes discussed above in which hypertension is the most prominent phenotype, several other familial syndromes have been described in which hypertension is one of the phenotypes: pheochromocytoma due to multiple endocrine neoplasia type IIB (MEN-IIB) syndrome, Cushing syndrome, 
Conn syndrome, renal artery stenosis due to fibromuscular dysplasia, congenital adrenal hyperplasia, and Bardet-Biedl syndrome.

\section{Essential hypertension}

In contrast with the Mendelian forms of hypertension discussed above, essential hypertension is a polygenetic disorder. No major gene which could explain most of the genetic component of the disorder seems to exist. On the contrary, several genes have been found, which all play a minor role in the total genetic component. These minor effects can probably be explained by the many regulatory mechanisms that are involved in blood pressure regulation, whereby the effects of a 'disturbing' gene can be easily compensated for by other homeostatic systems. Association studies are the most frequently used tool in the search for genes involved in essential hypertension. However, a positive association of certain polymorphisms with (intermediate) phenotypes do not mean that there is a causal explanation for the relation between gene and phenotype, but rather indicate that there is a statististical relation between them. Further studies are then needed to exactly elucidate the pathophysiology between the genetic mutation and the phenotype.

In this chapter we will mainly focus at polymorphisms of the RAS, but polymorphisms in several other blood pressure regulating genes have been described that showed associations with hypertension: $\alpha$-adducin, ${ }^{29} \mathrm{G}$-protein beta3-subunit, ${ }^{82}$ endothelial nitric oxide synthase, ${ }^{83}$ beta2-adrenergic receptor, ${ }^{84}$ and beta-subunit of the epithelial sodium channel. ${ }^{85}$

\section{Renin-angiotensin system}

The RAS, a complex cascade of proteases, is well known for its regulation of blood pressure and fluid homeostasis. The enzymatic cascade by which Angll is produced starts with renin, an aspartyl protease, secreted by myoepitheloid cells of the glomerular afferent arteriole, which cleaves AGT to form the decapeptide Angl (Figure 2.2). Angl is then further cleaved by ACE, a 170-kd dipeptidyl carboxypeptidase, to produce the octapeptide Angll, the physiologically active component of the system.

ACE is primarily attached to cell membranes and contains two catalytic domains, which differ in their function. Whereas the C-terminal site is responsible for approximately $75 \%$ of Angll-forming capacity, the $\mathrm{N}$-terminal domain has major functions in the processing of bradykinin, neurotensin, and substance P. In addition, a testicular form ( $90 \mathrm{kd}$, with only one catalytic domain), which has an important function in sperm differentiation, has been identified. ${ }^{86}$ In contrast to 
renin secretion, which is an endocrine process, ACE is largely responsible for AnglII conversion. The enzyme is expressed in high concentrations on the luminal surface of vascular endothelial cells, from where it is shed into the plasma by posttranslational proteolytic cleavage at such a high rate that in the systemic circulation, renin, rather than ACE availability, is the rate-limiting factor for the production of Angll. ${ }^{87.88}$ However, as shown by Danser et al., the greatest fraction of Angll is formed within the tissues, where baseline ACE activity is much lower, but where it can be increased by enhanced expression on smooth muscle or inflammatory cells, as well as fibroblasts. ${ }^{89}$ ACE also inactivates bradykinin, a peptide able to promote the release of important vascular mediators, including nitric oxide, prostacyclin, and tissue plasminogen activator. ${ }^{90}$ In this way, ACE has broad-ranging effects for the entire vascular homeostasis.

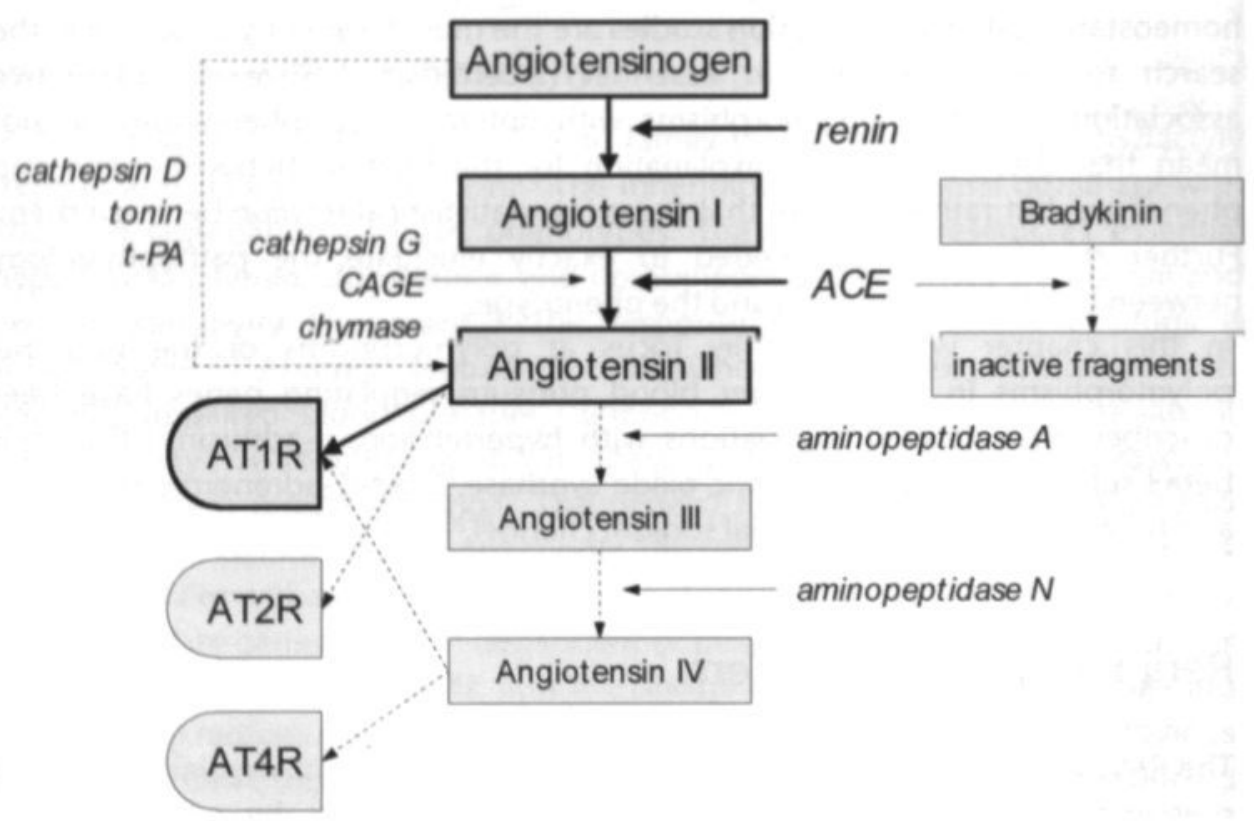

Figure 2.2. The renin-angiotensin system. The classic cascade of the renin-angiotensin system is shown in bold. Alternative side roads of the system is indicated by dotted arrows. ACE: angiotensin-converting enzyme, CAGE: chymostatin-sensitive angiotensin II-generating enzyme, t-PA: tissue plasminogen activator, AT1R: angiotensin II type 1 receptor, AT2R: angiotensin II type 2 receptor, AT4R: angiotensin II type 4 receptor.

Angll, the final effector of the system, causes vasoconstriction directly by stimulating the AT1R present on the vasculature and indirectly by increasing sympathetic tone and arginine vasopressin release. Chronically, Angll regulates blood pressure by modulating renal sodium and water reabsorption directly, by stimulating AT1R in the kidney, or indirectly, by stimulating the production and 
release of aldosterone from the adrenal glands, or stimulating the sensation of thirst in the central nervous system.

Further degradation (or processing) of Angll by aminopeptidase A and N produces AngllI (Ang2-8), and AnglV (Ang3-8), respectively. All these peptides are effective vasoconstrictors, though Anglll and AngIV are less potent than Angll.91,92

The actions of Angll result from its binding to specific receptors (AT1R and AT2R), which are classified by their differential affinities for various non-peptide antagonists. ${ }^{93}$ Though belonging to the same 7-transmembrane domain, Gprotein coupled-receptor family, the functions and signalling mechanisms of these receptor subtypes are quite different. While AT1R mediates the vasoconstrictive, proliferative and hypertrophy-promoting effects of Angll, AT2R stimulation promotes smooth muscle cell growth inhibition and phenotypic differentiation, vasodilation, natriuresis, and a decrease in extracellular matrix production.94.95 The AT1R preferentially binds Angll, while the AT2R preferentially binds AngllI. ${ }^{96}$ These receptors have a wide tissue-specific distribution, and are both present in the kidney, brain and adrenal glands. In general, AT1Rs are present in adult cardiovascular tissues, whereas AT2Rs are highly expressed in fetal life and decline rapidly after birth. ${ }^{97}$ AngIV preferentially interacts with another ATR: the AT4R. In contrast to the other ATRs this receptor does not seem to be a G-protein-coupled receptor..$^{98}$ It is widely distributed throughout the body.96.98 Suggested function of the AT4R subtype is (renal) vasodilatation. ${ }^{98,99}$

More recently, the presence of a renin receptor has been reported in the heart, brain, placenta, kidney, and liver. ${ }^{100}$ This receptor binds both renin and prorenin and binding increases the catalytic activity of renin to cleave AGT while rendering active prorenin.

Tissue RAS can be found in the brain, heart, vasculature, adipose tissue, gonads, pancreas, placenta, and kidney. ${ }^{101}$ The intrarenal RAS is hypothesized to regulate systemic blood pressure and various aspects of renal function such as local blood flow and sodium reabsorption, ${ }^{102}$ whereas in the brain it may facilitate neurotransmission and stimulate vasopressin release and sympathetic outflow. ${ }^{103,104}$ The tissue RAS concept is strongly supported by observations that hypertensive patients with normal or even low levels of systemic RAS activity can be effectively treated with inhibitors of the RAS. ${ }^{105}$

The RAS plays a key role in blood pressure regulation. Genes that encode components of the RAS are in turn thought to play a role in determining the genetic susceptibility to hypertension. Up to now, however, consistent associations between RAS genes and hypertension have been difficult to demonstrate. The inconsistencies in the association studies may arise from the inadequate power of small sample sizes, population structure, varying effects of several disease-predisposing variants, gene-environment interactions, or poor study design. Each of these factors can hinder the detection of a modest contribution of an individual locus to hypertension. 


\section{Angiotensinogen}

Jeunemaitre et al. showed that the AGT gene locus on chromosome 1q42-q43 was linked with hypertension in two large series of independently ascertained sibling pairs. ${ }^{24}$ Because of this linkage the AGT gene was further scanned, and it was found that in exon 2 of the gene a missense mutation exists, corresponding to a change from methionine $(M)$ to threonine $(T)$ at residue 235 of mature AGT. This M235T polymorphism was significantly associated with essential hypertension. Also, AGT levels were significantly associated with the genotype, with $\pi$ homozygotes exhibiting approximately $20 \%$ higher levels than MM homozygotes. ${ }^{24}$ Other studies demonstrated that the $235 \mathrm{~T}$ alleles are in linkage disequilibrium with allelic variants in the AGT promoter region (A-6G and A-20G), which may affect the basal rate of AGT transcription and could account for phenotypic variation in plasma AGT concentrations. 28,106-108 In line with the ACE insertion/deletion (I/D) polymorphism many linkage and association studies followed which reported conflicting results. ${ }^{26,109-111}$

Three meta-analyses concluded that the $235 \mathrm{~T}$ allele is associated with an increased risk (20-31\%) of hypertension. ${ }^{112-114}$ The meta-analysis of Staessen et al. suggested ethnic differences in the overall role of the $235 \mathrm{~T}$ allele as a hypertension marker, with positive associations noted for white individuals, but not for black individuals or Asians. ${ }^{113}$ In addition, the meta-analysis of Japanese association studies reported considerable heterogeneity and a wide variation in the $235 \mathrm{~T}$ allele frequencies $(60-83 \%)$ among control subjects. ${ }^{114}$

As discussed above it is plausible that not the $T$ but the $M$ allele is the mutant allele and that this mutation somehow is an evolutionary adaptation that decreases the risk for developing hypertension.

\section{Renin}

The human renin gene is located on $1 \mathrm{q} 32$, is $12.5 \mathrm{~kb}$ in length, and includes 10 exons and 9 introns. ${ }^{115}$ Renin is the rate-limiting factor of the RAS, plays a crucial role in the regulation of blood pressure, and its gene may therefore be an important candidate gene for hypertension. Strikingly enough several linkage studies showed the opposite. ${ }^{116-118}$ Several polymorphisms have been found, of which the Mbol dimorphism repeatedly showed associations with hypertension. ${ }^{119-121}$ However, a Japanese study could not confirm this. ${ }^{122}$

Fuchs et al. found a new SNP, C-5312T, located in the regulatory region of the renin gene. The level of renin transcription was $45 \%$ greater with the $-5312 \mathrm{~T}$ variant than with the $-5312 \mathrm{C}$ variant. ${ }^{123}$ Further studies should investigate whether this polymorphism is associated with plasma renin concentration, and/or increased blood pressure. 


\section{Angiotensin-converting enzyme}

The human ACE gene contains 26 exons and is located on chromosome 17q23. The structure of the gene suggests the duplication of an ancestral ACE gene. Exons 4-11 and 17-24, which encode the two homologous domains of the ACE molecule, are highly similar both in size and in sequence indicating a gene duplication event during evolution that may have occurred more than 600 million years ago. Both somatic and testicular ACE are derived from the same gene through the use of alternative promoters and differential splicing. ${ }^{124}$ The somatic ACE mRNA is transcribed from exons 1 to 26 , but exon 13 is spliced out. The testicular mRNA is transcribed from exons 13 to 26 using a testis-specific promoter in intron 12.125 The evolutionary conservation of these two forms of ACE indicates that both are functionally indispensable. ${ }^{126}$

The ACE gene is linked to hypertension in salt-loaded stroke-prone spontaneously hypertensive rats. ${ }^{127,128}$ Using gene targeting, Krege et al. constructed ACE -/- (i.e. homozygous null) mice and found that the blood pressure values of heterozygous male mice were 15 to $20 \mathrm{mmHg}$ less than normal. ${ }^{129}$ These and other studies focussed the attention to the human ACE gene as a potential candidate gene in human hypertension. A total of 78 molecular variants were identified for the human ACE gene. ${ }^{130}$ Among the 78 polymorphisms, the most prominent one is the insertion or deletion of a 287-basepair sequence in intron 16 of the gene. This Alu element was concluded to be an insertion (rather than a deletion) because its sequence has closest similarity to other human-specific Alu elements ${ }^{131}$ and PCR of chimpanzee DNA revealed a fragment consistent with a lack of an Alu. ${ }^{132}$ These data suggest that the Alu insertion occurred after the human-chimpanzee split. ${ }^{133}$ The intra-individual serum level of $A C E$ is rather stable. However, the interindividual variation is high. The ACE I/D polymorphism accounts for $47 \%$ of the total phenotypic variance of serum ACE. ${ }^{134}$ DD subjects have the highest, ID subjects intermediate, and II subjects the lowest concentrations of serum ACE. At least under some conditions, the genotype also is responsible for tissue ACE activity. Mizuiri et al. determined ACE mRNA in renal biopsy specimens obtained from healthy kidney donors. DD subjects had the highest number of ACE transcripts in $100 \mathrm{ng}$ of total RNA, compared to ID and II donors. ${ }^{135}$ The same investigators were also able to show similar patterns with regard to intrarenal ACE protein concentrations. ${ }^{136}$ In another study, cardiac ACE activity in patients who died of noncardiovascular disorders was significantly higher in DD subjects compared to ID and II subjects. ${ }^{137}$ Similar data were obtained in lymphocytes. ${ }^{138}$

Since the I/D polymorphism is an intronic marker, it may be functionally neutral but in strong linkage disequilibrium with another unidentified functional mutation within the ACE gene. Zhu et al. ${ }^{139}$ revealed two potential ancestral breakpoints in a 9-kb region of the 3'-region of the ACE gene that probably harbours a functional variant. This study suggests that the ACE I/D polymorphism may not be the functional quantitative trait locus (QTL) and the use of trans-ethnic 
mapping may help isolate the true functional QTL. The different degrees of linkage disequilibrium between the QTL and I/D polymorphism in different ethnic populations (e.g., Afro-Caribbeans, Caucasians, Chinese, Japanese) may account for some negative results in studies of ACE I/D genotype and cardiovascular disorders. ${ }^{140}$

The finding that serum ACE levels are (partly) genetically determined by the ACE I/D polymorphism, generated an enormous amount of association studies in which different cardiovascular phenotypes in different populations were investigated. Blood pressure and/or hypertension are the best studied phenotypes in relation to the ACE I/D polymorphism. Zee et al. were the first to report a positive association of the $A C E$ I/D polymorphism with essential hypertension in Caucasians. ${ }^{141}$ Hereafter, both positive ${ }^{142}$ and negative ${ }^{143-145}$ findings in Caucasians were reported. Two large, population-based studies found marginally significant linkage and association between blood pressure and the I/D polymorphism that was restricted to males. ${ }^{30,31}$ A genome scan for blood pressure from the Framingham Heart Study found strong evidence for a QTL on chromosome 17, close to the ACE gene. ${ }^{70}$ In patients of African descent, however, the associations of the ACE I/D polymorphism with blood pressure are usually positive. ${ }^{146-148}$ In Asian populations lastly, borderline significant, ${ }^{149}$ as well as no associations ${ }^{150,151}$ with hypertension are reported. Higaki et al. found significant associations between the ACE I/D polymorphism and essential hypertension only in Japanese men, ${ }^{152}$ as O'Donnell found in Caucasians. ${ }^{31}$

On the whole, studies in different countries give divergent results. Nevertheless, it appears that the association between the ACE I/D polymorphism and an increased risk of hypertension is consistently present in populations of African descent, while there might be a gender-specific association in Caucasians and Japanese.

\section{Angiotensin II type 1 receptor}

The human AT1R gene was cloned in $1992^{153}$ and is present as a single copy gene on human chromosome $3 q 22.154$ The gene spans more than $55 \mathrm{~kb}$ and comprises 5 exons and 4 introns. The entire coding region is located within exon 5. ${ }^{154,155}$ The gene is found to be highly polymorphic. Bonnardeaux et al. found 5 nonsense polymorphisms, of which the A1166C polymorphism was associated with hypertension. ${ }^{156}$ No evidence of linkage could be found in this study. A Finnish study, however, showed that of all the RAS genes as potential candidates, the AT1R gene was the only one whose locus was linked with hypertension. ${ }^{32}$ They also confirmed the previously described association of the A1166C polymorphism with hypertension, which others did as well. ${ }^{157.158}$ However, negative findings have also been reported. ${ }^{159-162}$

The AT1R A1166C polymorphism is located in the 3'-untranslated region (3'-UTR) of the gene. In this part of a gene mRNA stability is regulated. It is hypothesized that these regions play a role in changing gene expression in cardiovascular 
pathophysiology. ${ }^{163}$ The binding of AUF1, a protein that affects AT1R mRNA stability through binding to AU-rich regions of the 3'-UTR, is not affected by this polymorphism. ${ }^{164}$ As the promoter of a gene is important in gene function regulation, several studies searched for new polymorphisms in the promoter of the AT1R gene. ${ }^{165-168}$ Several new polymorphisms have been found, mostly in linkage disequilibrium with each other, but not with the $\mathrm{A} 1166 \mathrm{C}$ polymorphism in the 3'-UTR. ${ }^{165-167}$ One study showed a weak linkage disequilibrium between the mutant $A$ allele of the G-2228A promoter polymorphism and the mutant $C$ allele of the $\mathrm{A} 1166 \mathrm{C}$ polymorphism. ${ }^{168}$ However, in this study no association of any of the alleles with hypertension could be found. Takahashi et al. found an association of the promoter C-535T polymorphism with hypertension in Japanese, ${ }^{167}$ that could not be confirmed in Caucasians (described as C-521T). 165,168

\section{Angiotensin II type 2 receptor}

The human angiotensin II type 2 receptor (AT2R) gene is located on the $X$ chromosome (Xq22), spans about $5 \mathrm{~kb}$ and comprises two short noncoding exons, 2 introns and 1 coding exon (exon 3), which contains the entire protein coding region. ${ }^{169}$ Intron 1 contains transcriptional enhancers, and in vitro transcription is highest in constructs containing both intron 1 and exon 3.170 Animal studies suggest that the $A T 2 R$ plays an important role in the regulation of blood pressure. ${ }^{171,172}$ Three polymorphisms in the human AT2R gene, associated with cardiovascular abnormalities, have been described: the $\mathrm{T} 1334 \mathrm{C}$ polymorphism in the promoter region, ${ }^{173}$ the $\mathrm{G} 1675 \mathrm{~A}$ polymorphism within intron 1 near the region important for gene transcriptional activity, ${ }^{174}$ and the C3123A polymorphism within the 3'-UTR of exon 3.175 The G1675A polymorphism is associated with left ventricular structure in young males with early structural changes of the heart due to hypertension, ${ }^{174}$ whereas the $\mathrm{C} 3123 \mathrm{~A}$ polymorphism is associated with left ventricular structure in women with hypertrophic cardiomyopathy, but not in men, independently of the circulating RAS. ${ }^{176}$ Only 1 study focussed at hypertension as phenotype and described an association of the promoter T1334C polymorphism with hypertension in Chinese males. ${ }^{173}$

\section{Aldosterone}

The aldosterone synthase gene (CYP11B2) is located on $8 q 21$. The sequence of this gene is about $95 \%$ identical to its neighboring gene CYP11B1, encoding $11 \beta$ hydroxylase, in coding regions and $90 \%$ identical in introns. Both genes contain 9 exons and 8 introns and are arranged in tandem, $40 \mathrm{~kb}$ apart. The enzyme aldosterone synthase is the key rate-limiting enzyme in the final steps of aldosterone biosynthesis.

With respect to essential hypertension, studies have concentrated on 2 polymorphisms in the CYP11B2 gene. The C-344T SNP in the 5'-promoter region of 
the gene alters a putative recognition site for the transcription factor SF1. ${ }^{181}$ The immediate biologic importance of this is unclear: whereas binding of SF1 is reduced 4 -fold by the change from $C$ to $T$, there is no discernible effect on gene transcription studied in in vitro systems. ${ }^{182}$ Mutant $\mathrm{T}$ allele carriers have higher blood pressures, ${ }^{142,183-186}$ but this could not be confirmed in other studies. ${ }^{187-189}$ Aldosterone levels are increased in $\mathrm{T}$ allele carriers compared to $\mathrm{C}$ allele carriers, ${ }^{184,187}$ whereas Davies et al. found that the $T$ allele was associated with higher urinary aldosterone excretion. ${ }^{183}$ Inappropriate aldosterone production for the prevailing renin level might be an intermediate phenotypic expression of genetic variation at this locus. Lim et al. showed that more than $90 \%$ of hypertensives with an increased aldosterone-to-renin ratio (ARR) fail to suppress plasma aldosterone with salt loading and fludrocortisone.190 An increased frequency of the $T$ allele was reported in patients with raised ARR, ${ }^{191.193}$ but Tamaki et al. found that homozygosity for the $\mathrm{C}$ allele was associated with a higher ARR. ${ }^{194}$

The second polymorphism involves intron 2 of CYP11B2, which is replaced, in part, by the corresponding intron from CYP11B1. ${ }^{181}$ The C-344T and intron 2 polymorphisms are in linkage disequilibrium. ${ }^{181,191}$ Therefore positive associations of the intron 2 polymorphism with essential hypertension, 183,195 and with an increased ARR ${ }^{191.192}$ are in line with the findings with respect to the C-344T polymorphism.

\section{Summary}

As twin and adoption studies in the past already indicated, the genetic heritability in blood pressure resemblances is substantial: between 25-65\%. Growing evidence indicates that multiple genes are involved in blood pressure regulation, each having a modest effect on blood pressure. Although the genetic component of blood pressure heritability is substantial, environmental factors cannot be ruled out. The actual blood pressure of a subject is the resultant of a very complex play between many genetic, environmental and interacting factors. The thriftygenotype hypothesis implies that the genetic basis of contemporary modern diseases such as obesity, hypertension and diabetes mellitus is not to be found in recent mutations or genetic defects, but rather lies in the conservation of the ancestral version of the relevant genes. These genes are so-called thrifty genes that stem from African founders and that are needed to survive in a world with irregular availability of food (i.e. glucose) and sodium. In the last years, most progress in the study of genetic aspects of hypertension has been made by meticulously studying the several monogenic or Mendelian forms of hypertension. These findings also increased our knowledge of blood pressure regulation in the general population. Although the genes involved in these 
syndromes typically impart very large effects on blood pressure, the genes involved in essential hypertension mostly show modest effects. The extensive search for these genes revealed linkages with QTLs on almost all chromosomes. Candidate genes that showed significant linkage with hypertension are AGT, $\alpha$ adducin, ACE, and AT1R. Association studies are frequently hindered by aspects as underpoweredness, inhomogenously selected populations, publication bias, etc. Still, we may conclude that the following RAS polymorphisms are associated with hypertension: the M235T polymorphism in AGT, the insertion/deletion (I/D) polymorphism in ACE, the A1166C polymorphism in AT1R, and the C-344T polymorphism in aldosterone synthase. 


\section{References}

1. Staessen JA, Wang J, Bianchi G, Birkenhager WH. Essential hypertension. Lancet 2003;361: 1629-41.

2. Ezzati M, Lopez AD, Rodgers A, Vander Hoorn S, Murray CJ. Selected major risk factors and global and regional burden of disease. Lancet 2002;360:1347-60.

3. Risch N, Merikangas $\mathrm{K}$. The future of genetic studies of complex human diseases. Science 1996:273:1516-7.

4. Feinleib M, Garrison RJ, Fabsitz R, Christian JC, Hrubec Z, Borhani NO, Kannel WB, Rosenman R, Schwartz ת, Wagner JO. The NHLBI twin study of cardiovascular disease risk factors: methodology and summary of results. Am J Epidemiol 1977;106:284-5.

5. Longini IM, Jr., Higgins MW, Hinton PC, Moll PP, Keller JB. Environmental and genetic sources of familial aggregation of blood pressure in Tecumseh, Michigan. Am J Epidemiol 1984;120:131-44.

6. Biron P, Mongeau JG, Bertrand D. Familial aggregation of blood pressure in 558 adopted children. Can Med Assoc J 1976;115:773-4.

7. Rice T, Vogler GP, Perusse L, Bouchard C, Rao DC. Cardiovascular risk factors in a French Canadian population: resolution of genetic and familial environmental effects on blood pressure using twins, adoptees, and extensive information on environmental correlates. Genet Epidemiol 1989;6:571-88.

8. Borhani NO, Feinleib M, Garrison RJ, Christian JC, Rosenman RH. Genetic variance in blood pressure. Acta Genet Med Gemellol (Roma) 1976;25:137-44.

9. Smith TW, Turner CW, Ford MH, Hunt SC, Barlow GK, Stults BM, Williams RR. Blood pressure reactivity in adult male twins. Health Psychol 1987;6:209-20.

10. Harrap SB. Hypertension: genes versus environment. Lancet 1994;344:169-71.

11. Lifton RP, Gharavi AG, Geller DS. Molecular mechanisms of human hypertension. Cell 2001;104:545-56.

12. Pickering GW. Normotension and hypertension: the mysterious viability of the false. Am J Med 1978;65:561-3.

13. Platt R. Heredity in hypertension. Lancet 1963;i:899-904.

14. Doris PA. Hypertension genetics, single nucleotide polymorphisms, and the common disease:common variant hypothesis. Hypertension 2002;39:323-31.

15. Lander ES. The new genomics: global views of biology. Science 1996;274:536-9.

16. Underhill PA, Shen P, Lin AA, Jin L, Passarino G, Yang WH, Kauffman E, Bonne-Tamir B, Bertranpetit J, Francalacci P, Ibrahim M, Jenkins T, Kidd JR, Mehdi SQ Seielstad MT, Wells RS, Piazza A, Davis RW, Feldman MW, Cavalli-Sforza LL, Oefner PJ. Y chromosome sequence variation and the history of human populations. Nat Genet 2000;26:358-61.

17. Hammer MF. A recent common ancestry for human Y chromosomes. Nature 1995;378:376-8.

18. Harpending HC, Batzer MA, Gurven M, Jorde LB, Rogers AR, Sherry ST. Genetic traces of ancient demography. Proc Natl Acad SciU S A 1998;95:1961-7.

19. Zietkiewicz E, Yotova V, Jarnik M, Korab-Laskowska M, Kidd KK, Modiano D, Scozzari R, Stoneking M, Tishkoff S, Batzer M, Labuda D. Genetic structure of the ancestral population of modern humans. J Mol Evol 1998;47:146-55.

20. Neel JV. Diabetes mellitus: a thrifty genotype rendered detrimental by progress? Am J Hum Genet 1962;14:353-62.

21. Eaton SB, Konner $M$, Shostak $M$. Stone agers in the fast lane: chronic degenerative diseases in evolutionary perspective. Am J Med 1988;84:739-49.

22. Sibley CG, Ahlquist JE. The phylogeny of the hominoid primates, as indicated by DNA-DNA hybridization. J Mol Evol 1984:20:2-15.

23. Diamond JM. Human evolution. Diabetes running wild. Nature 1992;357:362-3.

24. Jeunemaitre X, Soubrier F, Kotelevtsev WV, Lifton RP, Williams CS, Charru A, Hunt SC, Hopkins PN, Williams RR, Lalouel JM, Corvol P. Molecular basis of human hypertension: role of angiotensinogen. Cell 1992;11:169-80. 
25. Hata A, Namikawa C, Sasaki M, Sato K, Nakamura T, Tamura K, Lalouel JM. Angiotensinogen as a risk factor for essential hypertension in Japan. JClin Invest 1994;93:1285-7.

26. Rotimi C, Morrison L, Cooper R, Oyejide C, Effiong E, Ladipo M, Osotemihen B, Ward R. Angiotensinogen gene in human hypertension. Lack of an association of the 235T allele among African Americans. Hypertension 1994;24:591-4.

27. Rotimi C, Puras A, Cooper R, McFarlane-Anderson N, Forrester T, Ogunbiyi O, Morrison L, Ward R. Polymorphisms of renin-angiotensin genes among Nigerians, Jamaicans, and African Americans. Hypertension 1996;27:558-63.

28. Inoue I, Nakajima T, Williams CS, Quackenbush J, Puryear R, Powers M, Cheng T, Ludwig EH, Sharma AM, Hata A, Jeunemaitre X, Lalouel JM. A nucleotide substitution in the promoter of human angiotensinogen is associated with essential hypertension and affects basal transcription in vitro. JClin Invest 1997;99:1786-97.

29. Cusi D, Barlassina C, Azzani T, Casari G, Citterio L, Devoto M, Glorioso N, Lanzani C, Manunta P, Righetti M, Rivera R, Stella P, Troffa C, Zagato L, Bianchi G. Polymorphisms of alpha-adducin and salt sensitivity in patients with essential hypertension. Lancet 1997;349:1353-7.

30. Fornage M, Amos Cl, Kardia S, Sing CF, Turner ST, Boerwinkle E. Variation in the region of the angiotensin-converting enzyme gene influences interindividual differences in blood pressure levels in young white males. Circulation 1998;97:1773-9.

31. O'Donnell CJ, Lindpaintner K, Larson MG, Rao VS, Ordovas JM, Schaefer EJ, Myers RH, Levy D. Evidence for association and genetic linkage of the angiotensin-converting enzyme locus with hypertension and blood pressure in men but not women in the Framingham Heart Study. Circulation 1998;97:1766-72.

32. Kainulainen K, Perola M, Terwilliger J, Kaprio J, Koskenvuo M, Syvanen AC, Vartiainen E, Peltonen L, Kontula K. Evidence for involvement of the type 1 angiotensin II receptor locus in essential hypertension. Hypertension 1999;33:844-9.

33. Greenberg DA. Linkage analysis of "necessary" disease loci versus "susceptibility" loci. Am J Hum Genet 1993;52:135-43.

34. Collins FS, Brooks LD, Chakravarti A. A DNA polymorphism discovery resource for research on human genetic variation. Genome Res 1998;8:1229-31.

35. Li WH, Sadler LA. Low nucleotide diversity in man. Genetics 1991;129:513-23.

36. Wang DG, Fan JB, Siao CJ, Berno A, Young P, Sapolsky R, Ghandour G, Perkins N, Winchester E, Spencer J, Kruglyak L, Stein L, Hsie L, Topaloglou T, Hubbell E, Robinson E, Mittmann M, Morris MS, Shen N, Kilburn D, Rioux J, Nusbaum C, Rozen S, Hudson TJ, Lander ES, et al. Large-scale identification, mapping, and genotyping of single-nucleotide polymorphisms in the human genome. Science 1998;280:1077-82.

37. Barbujani G, Magagni A, Minch E, Cavalli-Sforza LL. An apportionment of human DNA diversity. Proc Natl Acad Sci US A 1997;94:4516-9.

38. Sutherland DJ, Ruse JL, Laidlaw JC. Hypertension, increased aldosterone secretion and low plasma renin activity relieved by dexamethasone. Can Med Assoc J 1966;95:1109-19.

39. Rich GM, Ulick S, Cook S, Wang JZ, Lifton RP, Dluhy RG. Glucocorticoid-remediable aldosteronism in a large kindred: clinical spectrum and diagnosis using a characteristic biochemical phenotype. Ann Intern Med 1992;116:813-20.

40. Dluhy RG, Lifton RP. Glucocorticoid-remediable aldosteronism (GRA): diagnosis, variability of phenotype and regulation of potassium homeostasis. Steroids 1995;60:48-51.

41. Lifton RP, Dluhy RG, Powers M, Rich GM, Cook S, Ulick S, Lalouel JM. A chimaeric 11 betahydroxylase/aldosterone synthase gene causes glucocorticoid-remediable aldosteronism and human hypertension. Nature 1992;355:262-5.

42. Lifton RP, Dluhy RG, Powers M, Rich GM, Gutkin M, Fallo F, Gill JR, Jr., Feld L, Ganguly A, Laidlaw $J C$, et al. Hereditary hypertension caused by chimaeric gene duplications and ectopic expression of aldosterone synthase. Nat Genet 1992;2:66-74.

43. New MI, Levine LS, Biglieri EG, Pareira J, Ulick S. Evidence for an unidentified steroid in a child with apparent mineralocorticoid hypertension. J Clin Endocrinol Metab 1977;44:924-33.

44. Ulick S, Levine LS, Gunczler P, Zanconato G, Ramirez LC, Rauh W, Rosler A, Bradlow HL, New MI. A syndrome of apparent mineralocorticoid excess associated with defects in the peripheral metabolism of cortisol. J Clin Endocrinol Metab 1979;49:757-64. 
45. Arriza U, Weinberger C, Cerelli G, Glaser TM, Handelin BL, Housman DE, Evans RM. Cloning of human mineralocorticoid receptor complementary DNA: structural and functional kinship with the glucocorticoid receptor. Science 1987;237:268-75.

46. Funder JW, Pearce PT, Smith R, Smith Al. Mineralocorticoid action: target tissue specificity is enzyme, not receptor, mediated. Science 1988;242:583-5.

47. Stewart PM, Wallace AM, Valentino R, Burt D, Shackleton CH, Edwards CR. Mineralocorticoid activity of liquorice: 11-beta-hydroxysteroid dehydrogenase deficiency comes of age. Lancet 1987:2:821-4.

48. Mune T, Rogerson FM, Nikkila H, Agarwal AK, White PC. Human hypertension caused by mutations in the kidney isozyme of 11 beta-hydroxysteroid dehydrogenase. Nat Genet 1995;10:394-9.

49. Hurley DM, Accili D, Stratakis CA, Karl M, Vamvakopoulos N, Rorer E, Constantine K, Taylor SI, Chrousos GP. Point mutation causing a single amino acid substitution in the hormone binding domain of the glucocorticoid receptor in familial glucocorticoid resistance. $J$ Clin Invest 1991;87:680-6.

50. Geller DS, Farhi A, Pinkerton N, Fradley M, Moritz M, Spitzer A, Meinke G, Tsai FT, Sigler PB, Lifton RP. Activating mineralocorticoid receptor mutation in hypertension exacerbated by pregnancy. Science 2000;289:119-23.

51. Shimkets RA, Warnock DG, Bositis CM, Nelson-Williams C, Hansson JH, Schambelan M, Gill JR, Jr., Ulick S, Milora RV, Findling JW, Canessa CM, Rossier BC, Lifton RP. Liddle's syndrome: heritable human hypertension caused by mutations in the beta subunit of the epithelial sodium channel. Cell 1994;79:407-14.

52. Hansson JH, Nelson-Williams C, Suzuki H, Schild L, Shimkets R, Lu Y, Canessa C, Iwasaki T, Rossier B, Lifton RP. Hypertension caused by a truncated epithelial sodium channel gamma subunit: genetic heterogeneity of Liddle syndrome. Nat Genet 1995;11:76-82.

53. Schild L, Canessa CM, Shimkets RA, Gautschi I, Lifton RP, Rossier BC. A mutation in the epithelial sodium channel causing Liddle disease increases channel activity in the Xenopus laevis oocyte expression system. Proc Natl Acad Sci US A 1995;92:5699-703.

54. Snyder PM, Price MP, McDonald FJ, Adams CM, Volk KA, Zeiher BG, Stokes JB, Welsh MJ. Mechanism by which Liddle's syndrome mutations increase activity of a human epithelial $\mathrm{Na}+$ channel. Cell 1995;83:969-78.

55. Hansson JH, Schild L, Lu Y, Wilson TA, Gautschi I, Shimkets R, Nelson-Williams C, Rossier BC, Lifton RP. A de novo missense mutation of the beta subunit of the epithelial sodium channel causes hypertension and Liddle syndrome, identifying a proline-rich segment critical for regulation of channel activity. Proc Natl Acad SciU S A 1995;92:11495-9.

56. Inoue J, Iwaoka T, Tokunaga H, Takamune K, Naomi S, Araki M, Takahama K, Yamaguchi K, Tomita K. A family with Liddle's syndrome caused by a new missense mutation in the beta subunit of the epithelial sodium channel. J Clin Endocrinol Metab 1998;83:2210-3.

57. Schild L, Lu Y, Gautschi I, Schneeberger E, Lifton RP, Rossier BC. Identification of a PY motif in the epithelial $\mathrm{Na}$ channel subunits as a target sequence for mutations causing channel activation found in Liddle syndrome. Embo $\mathrm{J}$ 1996;15:2381-7.

58. Shimkets RA, Lifton RP, Canessa CM. The activity of the epithelial sodium channel is regulated by clathrin-mediated endocytosis. J Biol Chem 1997;272:25537-41.

59. Staub O, Dho S, Henry P, Correa J, Ishikawa T, McGlade J, Rotin D. WW domains of Nedd 4 bind to the proline-rich PY motifs in the epithelial Na+ channel deleted in Liddle's syndrome. Embo $J$ 1996;15:2371-80.

60. Kamynina E, Debonneville C, Bens M, Vandewalle A, Staub O. A novel mouse Nedd4 protein suppresses the activity of the epithelial Na+ channel. Faseb J 2001;15:204-14.

61. Abriel H, Loffing J, Rebhun JF, Pratt JH, Schild L, Horisberger JD, Rotin D, Staub O. Defective regulation of the epithelial $\mathrm{Na}+$ channel by Nedd4 in Liddle's syndrome. J Clin Invest 1999;103:667-73.

62. Schambelan M, Sebastian A, Rector FC, Jr. Mineralocorticoid-resistant renal hyperkalemia without salt wasting (type II pseudohypoaldosteronism): role of increased renal chloride reabsorption. Kidney Int 1981;19:716-27. 
63. Take C, Ikeda K, Kurasawa T, Kurokawa K. Increased chloride reabsorption as an inherited renal tubular defect in familial type II pseudohypoaldosteronism. N Engl J Med 1991;324:472-6.

64. Mayan H, Vered I, Mouallem M, Tzadok-Witkon M, Pauzner R, Farfel Z. Pseudohypoaldosteronism type II: marked sensitivity to thiazides, hypercalciuria, normomagnesemia, and low bone mineral density. J Clin Endocrinol Metab 2002;87:3248-54.

65. Mansfield TA, Simon DB, Farfel Z, Bia M, Tucci JR, Lebel M, Gutkin M, Vialettes B, Christofilis MA Kauppinen-Makelin R, Mayan H, Risch N, Lifton RP. Multilocus linkage of familial hyperkalaemia and hypertension, pseudohypoaldosteronism type II, to chromosomes 1q31-42 and 17p11-q21. Nat Genet 1997;16:202-5.

66. Disse-Nicodeme S, Achard JM, Desitter I, Houot AM, Fournier A, Corvol P, Jeunemaitre X. A new locus on chromosome 12p13.3 for pseudohypoaldosteronism type II, an autosomal dominant form of hypertension. Am J Hum Genet 2000;67:302-10.

67. Wilson FH, Disse-Nicodeme S, Choate KA, Ishikawa K, Nelson-Williams C, Desitter I, Gunel M, Milford DV, Lipkin GW, Achard JM, Feely MP, Dussol B, Berland Y, Unwin RJ, Mayan H, Simon DB, Farfel Z, Jeunemaitre X, Lifton RP. Human hypertension caused by mutations in WNK kinases. Science 2001;293:1107-12.

68. Simon DB, Nelson-Williams C, Bia MJ, Ellison D, Karet FE, Molina AM, Vaara I, Iwata F, Cushner HM, Koolen M, Gainza FJ, Gitleman HJ, Lifton RP. Gitelman's variant of Bartter's syndrome, inherited hypokalaemic alkalosis, is caused by mutations in the thiazide-sensitive $\mathrm{Na}-\mathrm{Cl}$ cotransporter. Nat Genet 1996;12:24-30.

69. Wilson FH, Kahle KT, Sabath E, Lalioti MD, Rapson AK, Hoover RS, Hebert SC, Gamba G, Lifton RP. Molecular pathogenesis of inherited hypertension with hyperkalemia: the $\mathrm{Na}-\mathrm{Cl}$ cotransporter is inhibited by wild-type but not mutant WNK4. Proc Natl Acad Sci U S A 2003;100:680-4.

70. Levy D, DeStefano AL, Larson MG, O'Donnell CJ, Lifton RP, Gavras H, Cupples LA, Myers RH. Evidence for a gene influencing blood pressure on chromosome 17. Genome scan linkage results for longitudinal blood pressure phenotypes in subjects from the framingham heart study. Hypertension 2000;36:477-83.

71. Baima J, Nicolaou M, Schwartz F, DeStefano AL, Manolis A, Gavras I, Laffer C, Elijovich F, Farrer L, Baldwin CT, Gavras H. Evidence for linkage between essential hypertension and a putative locus on human chromosome 17. Hypertension 1999;34:4-7.

72. Julier C, Delepine M, Keavney B, Terwilliger J, Davis S, Weeks DE, Bui T, Jeunemaitre X, Velho G, Froguel P, Ratcliffe P, Corvol P, Soubrier F, Lathrop GM. Genetic susceptibility for human familial essential hypertension in a region of homology with blood pressure linkage on rat chromosome 10. Hum Mol Genet 1997;6:2077-85.

73. Bilginturan N, Zileli S, Karacadag S, Pirnar T. Hereditary brachydactyly associated with hypertension. JMed Genet 1973;10:253-9.

74. Schuster H, Wienker TF, Toka HR, Bahring S, Jeschke E, Toka O, Busjahn A, Hempel A, Tahlhammer C, Oelkers W, Kunze J, Bilginturan N, Haller H, Luft FC. Autosomal dominant hypertension and brachydactyly in a Turkish kindred resembles essential hypertension. Hypertension 1996;28:108592.

75. Schuster H, Toka O, Toka HR, Busjahn A, Oztekin O, Wienker TF, Bilginturan N, Bahring S, Skrabal F, Haller H, Luft FC. A cross-over medication trial for patients with autosomal-dominant hypertension with brachydactyly. Kidney Int 1998;53:167-72.

76. Jordan J, Toka HR, Heusser K, Toka O, Shannon JR, Tank J, Diedrich A, Stabroth C, Stoffels M, Naraghi R, Oelkers W, Schuster H, Schobel HP, Haller H, Luft FC. Severely impaired baroreflexbuffering in patients with monogenic hypertension and neurovascular contact. Circulation 2000;102:2611-8.

77. Naraghi R, Schuster H, Toka HR, Bahring S, Toka O, Oztekin O, Bilginturan N, Knoblauch H, Wienker TF, Busjahn A, Haller H, Fahlbusch R, Luft FC. Neurovascular compression at the ventrolateral medulla in autosomal dominant hypertension and brachydactyly. Stroke 1997;28:1749-54.

78. Schuster H, Wienker TE, Bahring S, Bilginturan N, Toka HR, Neitzel H, Jeschke E, Toka O, Gilbert D, Lowe A, Ott J, Haller H, Luft FC. Severe autosomal dominant hypertension and brachydactyly in a unique Turkish kindred maps to human chromosome 12. Nat Genet 1996;13:98-100. 
79. Gong $M$, Zhang $H$, Schulz H, Lee YA, Sun K, Bahring S, Luft FC, Nurnberg P, Reis A, Rohde K, Ganten D, Hui R, Hubner N. Genome-wide linkage reveals a locus for human essential (primary) hypertension on chromosome 12p. Hum Mol Genet 2003;12:1273-7.

80. Bahring S, Rauch A, Toka O, Schroeder C, Hesse C, Siedler H, Fesus G, Haefeli WE, Busjahn A, Aydin A, Neuenfeld Y, Muhl A, Toka HR, Gollasch M, Jordan J, Luft FC. Autosomal-dominant hypertension with type e brachydactyly is caused by rearrangement on the short arm of chromosome 12. Hypertension 2004;43:471-6.

81. Luft FC, Toka O, Toka HR, Jordan J, Bahring S. Mendelian hypertension with brachydactyly as a molecular genetic lesson in regulatory physiology. Am J Physiol Regul Integr Comp Physiol 2003;285:R709-14.

82. Siffert W, Rosskopf D, Siffert G, Busch S, Moritz A, Erbel R, Sharma AM, Ritz E, Wichmann HE, Jakobs $\mathrm{KH}$, Horsthemke B. Association of a human G-protein beta3 subunit variant with hypertension. Nat Genet 1998;18:45-8.

83. Miyamoto Y, Saito Y, Kajiyama N, Yoshimura M, Shimasaki Y, Nakayama M, Kamitani S, Harada M, Ishikawa M, Kuwahara K, Ogawa E, Hamanaka I, Takahashi N, Kaneshige T, Teraoka H, Akamizu T, Azuma N, Yoshimasa Y, Yoshimasa T, Itoh H, Masuda I, Yasue H, Nakao K. Endothelial nitric oxide synthase gene is positively associated with essential hypertension. Hypertension 1998;32:3-8.

84. Timmermann B, Mo R, Luft FC, Gerdts E, Busjahn A, Omvik P, Li GH, Schuster H, Wienker TF, Hoehe MR, Lund-Johansen P. Beta-2 adrenoceptor genetic variation is associated with genetic predisposition to essential hypertension: The Bergen Blood Pressure Study. Kidney Int 1998;53:1455-60.

85. Baker EH, Dong YB, Sagnella GA, Rothwell M, Onipinla AK, Markandu ND, Cappuccio FP, Cook DG, Persu A, Corvol P, Jeunemaitre X, Carter ND, MacGregor GA. Association of hypertension with T594M mutation in beta subunit of epithelial sodium channels in black people resident in London. Lancet 1998;351:1388-92.

86. Mayer G. ACE genotype and ACE inhibitor response in kidney disease: a perspective. Am J Kidney Dis 2002;40:227-35.

87. Ardaillou R, Michel JB. The relative roles of circulating and tissue renin-angiotensin systems. Nephrol Dial Transplant 1999;14:283-6.

88. Hollenberg NK. Pharmacologic interruption of the renin-angiotensin system and the kidney: differential responses to angiotensin-converting enzyme and renin inhibition. J Am Soc Nephrol 1999;10 Suppl 11:\$239-42.

89. Danser AH, Koning MM, Admiraal PJ, Sassen LM, Derkx FH, Verdouw PD, Schalekamp MA. Production of angiotensins I and II at tissue sites in intact pigs. Am J Physiol 1992;263:H429-37.

90. Dzau VJ. Cell biology and genetics of angiotensin in cardiovascular disease. J Hypertens Suppl 1994;12:S3-10.

91. Moeller I, Allen AM, Chai SY, Zhuo J, Mendelsohn FA. Bioactive angiotensin peptides. J Hum Hypertens 1998;12:289-93.

92. Stroth $U$, Unger T. The renin-angiotensin system and its receptors. J Cardiovasc Pharmacol 1999;33 Suppl 1:S21-8.

93. Timmermans PB, Wong PC, Chiu AT, Herblin WF, Benfield P, Carini DJ, Lee RJ, Wexler RR, Saye JA, Smith RD. Angiotensin II receptors and angiotensin II receptor antagonists. Pharmacol Rev 1993;45:205-51.

94. Horiuchi M, Akishita M, Dzau VJ. Recent progress in angiotensin II type 2 receptor research in the cardiovascular system. Hypertension 1999;33:613-21.

95. Carey RM, Wang ZQ. Siragy HM. Role of the angiotensin type 2 receptor in the regulation of blood pressure and renal function. Hypertension 2000;35:155-63.

96. Wright JW, Krebs LT, Stobb JW, Harding JW. The angiotensin IV system: functional implications. Front Neuroendocrinol 1995; 16:23-52.

97. Shanmugam S, Llorens-Cortes C, Clauser E, Corvol P, Gasc JM. Expression of angiotensin II AT2 receptor mRNA during development of rat kidney and adrenal gland. Am J Physiol 1995;268:F92230.

98. Swanson GN, Hanesworth JM, Sardinia MF, Coleman JK, Wright JW, Hall KL, Miller-Wing AV, Stobb JW, Cook VI, Harding EC, et al. Discovery of a distinct binding site for angiotensin II (3-8), a putative angiotensin IV receptor. Regul Pept 1992;40:409-19. 
99. Fogo AB. New insights into the renin-angiotensin system and hypertensive renal disease. Curr Hypertens Rep 1999;1:187-94.

100. Nguyen G, Delarue F, Burckle C, Bouzhir L, Giller T, Sraer JD. Pivotal role of the renin/prorenin receptor in angiotensin II production and cellular responses to renin. J Clin Invest 2002;109: 1417-27.

101. Lavoie JL, Sigmund CD. Minireview: overview of the renin-angiotensin system-an endocrine and paracrine system. Endocrinology 2003;144:2179-83.

102. Navar LG, Imig JD, Zou L, Wang CT. Intrarenal production of angiotensin II. Semin Nephrol 1997;17:412-22.

103. Costa M, Majewski $\mathrm{H}$. Facilitation of noradrenaline release from sympathetic nerves through activation of ACTH receptors, beta-adrenoceptors and angiotensin II receptors. Br J Pharmacol 1988;95:993-1001.

104. Steckelings U, Lebrun C, Qadri F, Veltmar A, Unger T. Role of brain angiotensin in cardiovascular regulation. J Cardiovasc Pharmacol 1992;19 Suppl 6:S72-9.

105. Dzau VJ, Bernstein K, Celermajer D, Cohen J, Dahlof B, Deanfield J, Diez J, Drexler H, Ferrari R, van Gilst W, Hansson L, Hornig B, Husain A, Johnston C, Lazar H, Lonn E, Luscher T, Mancini J, Mimran A, Pepine C, Rabelink T, Remme W, Ruilope L, Ruzicka M, Schunkert H, Swedberg K, Unger T, Vaughan D, Weber M. The relevance of tissue angiotensin-converting enzyme: manifestations in mechanistic and endpoint data. Am J Cardiol 2001;88:1L-20L.

106. Jeunemaitre $X$, Inoue I, Williams C, Charru A, Tichet J, Powers M, Sharma AM, Gimenez-Roqueplo AP, Hata A, Corvol P, Lalouel JM. Haplotypes of angiotensinogen in essential hypertension. Am J Hum Genet 1997;60:1448-60.

107. Zhao YY, Zhou J, Narayanan CS, Cui Y, Kumar A. Role of C/A polymorphism at -20 on the expression of human angiotensinogen gene. Hypertension 1999;33:108-15.

108. Ishigami T, Umemura S, Tamura K, Hibi K, Nyui N, Kihara M, Yabana M, Watanabe Y, Sumida Y, Nagahara T, Ochiai H, Ishii M. Essential hypertension and 5' upstream core promoter region of human angiotensinogen gene. Hypertension 1997;30:1325-30.

109. Caulfield M, Lavender P, Farrall M, Munroe P, Lawson M, Turner P, Clark AJ. Linkage of the angiotensinogen gene to essential hypertension. N Engl J Med 1994;330:1629-33.

110. Caulfield M, Lavender P, Newell-Price J, Farrall M, Kamdar S, Daniel H, Lawson M, De Freitas P, Fogarty $\mathrm{P}, \mathrm{Clark} \mathrm{AJ}$. Linkage of the angiotensinogen gene locus to human essential hypertension in African Caribbeans. J Clin Invest 1995;96:687-92.

111. Fornage M, Turner ST, Sing CF, Boerwinkle E. Variation at the M235T locus of the angiotensinogen gene and essential hypertension: a population-based case-control study from Rochester, Minnesota. Hum Genet 1995;96:295-300.

112. Kunz R, Kreutz R, Beige J, Distler A, Sharma AM. Association between the angiotensinogen 235Tvariant and essential hypertension in whites: a systematic review and methodological appraisal. Hypertension 1997;30:1331-7.

113. Staessen JA, Kuznetsova T, Wang JG, Emelianov D, Vlietinck R, Fagard R. M235T angiotensinogen gene polymorphism and cardiovascular renal risk. J Hypertens 1999;17:9-17.

114. Kato N, Sugiyama T, Morita H, Kurihara $H$, Yamori $Y$, Yazaki $Y$. Angiotensinogen gene and essential hypertension in the Japanese: extensive association study and meta-analysis on six reported studies. J Hypertens 1999;17:757-63.

115. Hobart PM, Fogliano M, O'Connor BA, Schaefer IM, Chirgwin JM. Human renin gene: structure and sequence analysis. Proc Natl Acad Sci US A 1984;81:5026-30.

116. Naftilan AJ, Williams R, Burt D, Paul M, Pratt RE, Hobart P, Chirgwin J, Dzau VJ. A lack of genetic linkage of renin gene restriction fragment length polymorphisms with human hypertension. Hypertension 1989;14:614-8.

117. Zee RY, Ying LH, Morris BJ, Griffiths LR. Association and linkage analyses of restriction fragment length polymorphisms for the human renin and antithrombin III genes in essential hypertension. J Hypertens 1991;9:825-30.

118. Jeunemaitre $X$, Rigat B, Charru A, Houot AM, Soubrier F, Corvol P. Sib pair linkage analysis of renin gene haplotypes in human essential hypertension. Hum Genet 1992;88:301-6. 
119. Okura T, Kitami $Y$, Hiwada $K$. Restriction fragment length polymorphisms of the human renin gene: association study with a family history of essential hypertension. J Hum Hypertens 1993;7:457-61.

120. Frossard PM, Lestringant GG, Elshahat YI, John A, Obineche EN. An Mbol two-allele polymorphism may implicate the human renin gene in primary hypertension. Hypertens Res 1998;21:221-5.

121. Frossard PM, Kane JP, Malloy MJ, Bener A. Renin gene Mbol dimorphism is a discriminator for hypertension in hyperlipidaemic subjects. Hypertens Res 1999;22:285-9.

122. Fu Y, Katsuya T, Asai T, Fukuda M, Inamoto N, Iwashima Y, Sugimoto K, Rakugi H, Higaki J, Ogihara $\mathrm{T}$. Lack of correlation between Mbo I restriction fragment length polymorphism of renin gene and essential hypertension in Japanese. Hypertens Res 2001;24:295-8.

123. Fuchs S, Philippe J, Germain S, Mathieu F, Jeunemaitre X, Corvol P, Pinet F. Functionality of two new polymorphisms in the human renin gene enhancer region. $J$ Hypertens 2002;20:2391-8.

124. Kumar RS, Thekkumkara TJ, Sen GC. The mRNAs encoding the two angiotensin-converting isozymes are transcribed from the same gene by a tissue-specific choice of alternative transcription initiation sites. J Biol Chem 1991;266:3854-62.

125. Howard TE, Shai SY, Langford KG, Martin BM, Bernstein KE. Transcription of testicular angiotensinconverting enzyme (ACE) is initiated within the 12th intron of the somatic ACE gene. Mol Cell Biol 1990;10:4294-302.

126. Corvol P, Williams TA, Soubrier F. Peptidyl dipeptidase A: angiotensin I-converting enzyme. Methods Enzymol 1995;248:283-305.

127. Hilbert $P$, Lindpaintner $K$, Beckmann JS, Serikawa T, Soubrier F, Dubay C, Cartwright $P$, De Gouyon B, Julier C, Takahasi S, et al. Chromosomal mapping of two genetic loci associated with bloodpressure regulation in hereditary hypertensive rats. Nature 1991;353:521-9.

128. Jacob HJ, Lindpaintner K, Lincoln SE, Kusumi K, Bunker RK, Mao YP, Ganten D, Dzau VJ, Lander ES. Genetic mapping of a gene causing hypertension in the stroke-prone spontaneously

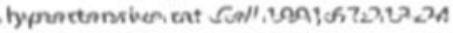

129. Krege JH, John SW, Langenbach LL, Hodgin JB, Hagaman JR, Bachman ES, Jennette JC, O'Brien DA, Smithies O. Male-female differences in fertility and blood pressure in ACE-deficient mice. Nature 1995;375:146-8.

130. Rieder MJ, Taylor SL, Clark AG, Nickerson DA. Sequence variation in the human angiotensin converting enzyme. Nat Genet 1999;22:59-62.

131. Batzer MA, Stoneking M, Alegria-Hartman M, Bazan H, Kass DH, Shaikh TH, Novick GE, loannou PA, Scheer WD, Herrera RJ, et al. African origin of human-specific polymorphic Alu insertions. Proc Natl Acad SciU S A 1994;91:12288-92.

132. Dufour C, Casane D, Denton D, Wickings J, Corvol P, Jeunemaitre X. Human-chimpanzee DNA sequence variation in the four major genes of the renin angiotensin system. Genomics 2000;69:14-26.

133. Niu T, Chen $X, X u X$. Angiotensin converting enzyme gene insertion/deletion polymorphism and cardiovascular disease: therapeutic implications. Drugs 2002;62:977-93.

134. Rigat B, Hubert C, Alhenc-Gelas F, Cambien F, Corvol P, Soubrier F. An insertion/deletion polymorphism in the angiotensin I-converting enzyme gene accounting for half the variance of serum enzyme levels. J Clin Invest 1990;86:1343-6.

135. Mizuiri S, Hemmi H, Kumanomidou H, Iwamoto M, Miyagi M, Sakai K, Aikawa A, Ohara T, Yamada $K$, Shimatake $H$, Hasegawa A. Angiotensin-converting enzyme (ACE) I/D genotype and renal ACE gene expression. Kidney Int 2001;60:1124-30.

136. Mizuiri S, Yoshikawa H, Tanegashima M, Miyagi M, Kobayashi M, Sakai K, Hayashi I, Aikawa A, Ohara T, Hasegawa A. Renal ACE immunohistochemical localization in NIDDM patients with nephropathy. Am J Kidney Dis 1998;31:301-7.

137. Danser AH, Schalekamp MA, Bax WA, van den Brink AM, Saxena PR, Riegger GA, Schunkert $H$. Angiotensin-converting enzyme in the human heart. Effect of the deletion/insertion polymorphism. Circulation 1995;92:1387-8.

138. Costerousse $O$, Allegrini J, Lopez M, Alhenc-Gelas $F$. Angiotensin I-converting enzyme in human circulating mononuclear cells: genetic polymorphism of expression in T-lymphocytes. Biochem J 1993;290:33-40. 
139. Zhu X, McKenzie CA, Forrester T, Nickerson DA, Broeckel U, Schunkert H, Doering A, Jacob HJ, Cooper RS, Rieder MJ. Localization of a small genomic region associated with elevated ACE. Am J Hum Genet 2000;67:1144-53.

140. McKenzie CA, Julier C, Forrester T, McFarlane-Anderson N, Keavney B, Lathrop GM, Ratcliffe PJ, Farrall M. Segregation and linkage analysis of serum angiotensin 1-converting enzyme levels: evidence for two quantitative-trait loci. Am J Hum Genet 1995;57:1426-35.

141. Zee RY, Lou YK, Griffiths LR, Morris BJ. Association of a polymorphism of the angiotensin Iconverting enzyme gene with essential hypertension. Biochem Biophys Res Commun 1992;184: 9-15.

142. Staessen JA, Wang JG, Brand E, Barlassina C, Birkenhager WH, Herrmann SM, Fagard R, Tizzoni L, Bianchi G. Effects of three candidate genes on prevalence and incidence of hypertension in a Caucasian population. J Hypertens 2001;19:1349-58.

143. Schmidt S, van Hooft IM, Grobbee DE, Ganten D, Ritz E. Polymorphism of the angiotensin I converting enzyme gene is apparently not related to high blood pressure: Dutch Hypertension and Offspring Study. J Hypertens 1993;11:345-8.

144. Gu XX, Spaepen M, Guo C, Fagard R, Amery A, Lijnen P, Cassiman JJ. Lack of association between the $\mathrm{V} / \mathrm{D}$ polymorphism of the angiotensin-converting enzyme gene and essential hypertension in a Belgian population. J Hum Hypertens 1994;8:683-5.

145. Vassilikioti S, Doumas M, Douma S, Petidis K, Karagiannis A, Balaska K, Vyzantiadis A, Zamboulis C. Angiotensin converting enzyme gene polymorphism is not related to essential hypertension in a Greek population. Am J Hypertens 1996;9:700-2.

146. Duru K, Farrow S, Wang JM, Lockette W, Kurtz T. Frequency of a deletion polymorphism in the gene for angiotensin converting enzyme is increased in African-Americans with hypertension. Am J Hypertens 1994;7:759-62.

147. Asamoah A, Yanamandra K, Thurmon TF, Richter R, Green R, Lakin T, Martin C. A deletion in the angiotensin converting enzyme (ACE) gene is common among African Americans with essential hypertension. Clin Chim Acta 1996;254:41-6.

148. Barley J, Blackwood A, Miller M, Markandu ND, Carter ND, Jeffery S, Cappuccio FP, MacGregor GA, Sagnella GA. Angiotensin converting enzyme gene I/D polymorphism, blood pressure and the renin-angiotensin system in Caucasian and Afro-Caribbean peoples. J Hum Hypertens 1996;10:315 .

149. Jeng JR, Harn HJ, Jeng CY, Yueh KC, Shieh SM. Angiotensin I converting enzyme gene polymorphism in Chinese patients with hypertension. Am J Hypertens 1997; 10:558-61.

150. Zaman MM, Yoshiike N, Date C, Yokoyama T, Matsumura Y, Ikemoto S, Tanaka H. Angiotensin converting enzyme genetic polymorphism is not associated with hypertension in a crosssectional sample of a Japanese population: the Shibata Study. J Hypertens 2001;19:47-53.

151. Sugiyama T, Morita H, Kato N, Kurihara H, Yamori Y, Yazaki Y. Lack of sex-specific effects on the association between angiotensin-converting enzyme gene polymorphism and hypertension in Japanese. Hypertens Res 1999;22:55-9.

152. Higaki J, Baba S, Katsuya T, Sato N, Ishikawa K, Mannami T, Ogata J, Ogihara T. Deletion allele of angiotensin-converting enzyme gene increases risk of essential hypertension in Japanese men : the Suita Study. Circulation 2000;101:2060-5.

153. Bergsma DJ, Ellis C, Kumar C, Nuthulaganti P, Kersten H, Elshourbagy N, Griffin E, Stadel JM, Aiyar $\mathrm{N}$. Cloning and characterization of a human angiotensin II type 1 receptor. Biochem Biophys Res Commun 1992;183:989-95.

154. Curnow KM, Pascoe L, White PC. Genetic analysis of the human type-1 angiotensin II receptor. Mol Endocrinol 1992;6:1113-8.

155. Guo DF, Furuta H, Mizukoshi M, Inagami T. The genomic organization of human angiotensin ॥ type 1 receptor. Biochem Biophys Res Commun 1994;200:313-9.

156. Bonnardeaux A, Davies E, Jeunemaitre X, Fery I, Charru A, Clauser E, Tiret L, Cambien F, Corvol P, Soubrier F. Angiotensin II type 1 receptor gene polymorphisms in human essential hypertension. Hypertension 1994;24:63-9.

157. Wang WY, Zee RY, Morris BJ. Association of angiotensin II type 1 receptor gene polymorphism with essential hypertension. Clin Genet 1997;51:31-4. 
158. Dzida G, Sobstyl J, Puzniak A, Golon P, Mosiewicz J, Hanzlik J. Polymorphisms of angiotensinconverting enzyme and angiotensin II receptor type 1 genes in essential hypertension in a Polish population. Med Sci Monit 2001;7:1236-41.

159. Castellano M, Muiesan ML, Beschi M, Rizzoni D, Cinelli A, Salvetti M, Pasini G, Porteri E, Bettoni G, Zulli R, Agabiti-Rosei E. Angiotensin II type 1 receptor A/C1166 polymorphism. Relationships with blood pressure and cardiovascular structure. Hypertension 1996;28:1076-80.

160. Schmidt S, Beige J, Walla-Friedel M, Michel MC, Sharma AM, Ritz E. A polymorphism in the gene for the angiotensin II type 1 receptor is not associated with hypertension. J Hypertens 1997; 15:1385-8.

161. Berge KE, Berg K. Polymorphisms at the angiotensinogen (AGT) and angiotensin II type 1 receptor (AT1R) loci and normal blood pressure. Clin Genet 1998;53:214-9.

162. Takami S, Katsuya T, Rakugi H, Sato N, Nakata Y, Kamitani A, Miki T, Higaki J, Ogihara T. Angiotensin II type 1 receptor gene polymorphism is associated with increase of left ventricular mass but not with hypertension. Am J Hypertens 1998;11:316-21.

163. Misquitta CM, lyer VR, Werstiuk ES, Grover AK. The role of 3'-untranslated region (3'-UTR) mediated mRNA stability in cardiovascular pathophysiology. Mol Cell Biochem 2001;224:53-67.

164. Pende A, Giacche M, Castigliola L, Contini L, Passerone G, Patrone M, Port JD, Lotti G. Characterization of the binding of the RNA-binding protein AUF1 to the human AT(1) receptor mRNA. Biochem Biophys Res Commun 1999;266:609-14.

165. Poirier O, Georges JL, Ricard S, Arveiler D, Ruidavets JB, Luc G, Evans A, Cambien F, Tiret L. New polymorphisms of the angiotensin II type 1 receptor gene and their associations with myocardial infarction and blood pressure: the ECTIM study. Etude Cas-Temoin de I'Infarctus du Myocarde. $J$ Hypertens 1998;16:1443-7.

166. Erdmann J, Riedel K, Rohde K, Folgmann I, Wienker T, Fleck E, Regitz-Zagrosek V. Characterization of polymorphisms in the promoter of the human angiotensin II subtype 1 (AT1) receptor gene. Ann Hum Genet 1999;63:369-74.

167. Takahashi N, Murakami H, Kodama K, Kasagi F, Yamada M, Nishishita T, Inagami T. Association of a polymorphism at the 5'-region of the angiotensin II type 1 receptor with hypertension. Ann Hum Genet 2000;64:197-205.

168. Zhang X, Erdmann J, Regitz-Zagrosek V, Kurzinger S, Hense HW, Schunkert H. Evaluation of three polymorphisms in the promoter region of the angiotensin II type I receptor gene. J Hypertens 2000;18:267-72.

169. Martin MM, Elton TS. The sequence and genomic organization of the human type 2 angiotensin II receptor. Biochem Biophys Res Commun 1995;209:554-62.

170. Warnecke C, Willich T, Holzmeister J, Bottari SP, Fleck E, Regitz-Zagrosek V. Efficient transcription of the human angiotensin II type 2 receptor gene requires intronic sequence elements. Biochem $J$ 1999;340:17-24.

171. Ichiki T, Labosky PA, Shiota C, Okuyama S, Imagawa Y, Fogo A, Niimura F, Ichikawa I, Hogan BL, Inagami T. Effects on blood pressure and exploratory behaviour of mice lacking angiotensin ॥ type-2 receptor. Nature 1995;377:748-50.

172. Tsutsumi $Y$, Matsubara $H$, Masaki $H$, Kurihara $H$, Murasawa S, Takai S, Miyazaki M, Nozawa $Y$, Ozono R, Nakagawa K, Miwa T, Kawada N, Mori Y, Shibasaki Y, Tanaka Y, Fujiyama S, Koyama Y, Fujiyama A, Takahashi $\mathrm{H}$, Iwasaka T. Angiotensin II type 2 receptor overexpression activates the vascular kinin system and causes vasodilation. J Clin Invest 1999;104:925-35.

173. Zhang $\mathrm{Y}$, Zhang KX, Wang GL, Huang W, Zhu DL. Angiotensin II type 2 receptor gene polymorphisms and essential hypertension. Acta Pharmacol Sin 2003;24:1089-93.

174. Schmieder RE, Erdmann J, Delles C, Jacobi J, Fleck E, Hilgers K, Regitz-Zagrosek V. Effect of the angiotensin II type 2-receptor gene (+1675 G/A) on left ventricular structure in humans. J Am Coll Cardiol 2001;37:175-82.

175. Katsuya T, Horiuchi M, Minami S, Koike G, Santoro NF, Hsueh AJ, Dzau VJ. Genomic organization and polymorphism of human angiotensin II type 2 receptor: no evidence for its gene mutation in two families of human premature ovarian failure syndrome. Mol Cell Endocrinol 1997;127:221-8.

176. Deinum J, van Gool JM, Kofflard MJ, ten Cate FJ, Danser AH. Angiotensin II type 2 receptors and cardiac hypertrophy in women with hypertrophic cardiomyopathy. Hypertension 2001;38: 1278-81. 
177. Miller RE, Vander AJ, Kowalczyk S, Geelhoed GW. Aldosterone secretion and plasma renin during renin infusion and acute salt depletion. Am J Physiol 1968;214:228-31.

178. Curnow KM, Tusie-Luna MT, Pascoe L, Natarajan R, Gu JL, Nadler JL, White PC. The product of the CYP11B2 gene is required for aldosterone biosynthesis in the human adrenal cortex. Mol Endocrinol 1991;5:1513-22.

179. Cicila GT, Rapp JP, Wang JM, St Lezin E, Ng SC, Kurtz TW. Linkage of 11 beta-hydroxylase mutations with altered steroid biosynthesis and blood pressure in the Dahl rat. Nat Genet 1993;3:346-53.

180. Curnow KM, Slutsker L, Vitek J, Cole T, Speiser PW, New MI, White PC, Pascoe L. Mutations in the CYP11B1 gene causing congenital adrenal hyperplasia and hypertension cluster in exons 6, 7, and 8. Proc Natl Acad Sci U S A 1993;90:4552-6.

181. White PC, Slutsker L. Haplotype analysis of CYP1 1B2. Endocr Res 1995;21:437-42.

182. Bassett $M H$, Zhang $Y$, Clyne $C$, White PC, Rainey WE. Differential regulation of aldosterone synthase and 11 beta-hydroxylase transcription by steroidogenic factor-1. $J$ Mol Endocrinol 2002;28:125-35.

183. Davies E, Holloway CD, Ingram MC, Inglis GC, Friel EC, Morrison C, Anderson NH, Fraser R, Connell JM. Aldosterone excretion rate and blood pressure in essential hypertension are related to polymorphic differences in the aldosterone synthase gene CYP11B2. Hypertension 1999;33: 703-7.

184. Paillard F, Chansel D, Brand E, Benetos A, Thomas F, Czekalski S, Ardaillou R, Soubrier F. Genotype-phenotype relationships for the renin-angiotensin-aldosterone system in a normal population. Hypertension 1999;34:423-9.

185. Brand E, Chatelain N, Mulatero P, Fery I, Curnow K, Jeunemaitre X, Corvol P, Pascoe L, Soubrier F. Structural analysis and evaluation of the aldosterone synthase gene in hypertension. Hypertension 1998;32:198-204.

186. Castellano M, Glorioso N, Cusi D, Sarzani R, Fabris B, Opocher G, Zoccali C, Golin R, Veglio F, Volpe M, Mantero F, Fallo F, Rossi GP, Barlassina C, Tizzoni L, Filigheddu F, Giacche M, Rossi F. Genetic polymorphism of the renin-angiotensin-aldosterone system and arterial hypertension in the Italian population: the GENIPER Project. J Hypertens 2003;21:1853-60.

187. Pojoga L, Gautier S, Blanc H, Guyene T, Poirier O, Cambien F, Benetos A. Genetic determination of plasma aldosterone levels in essential hypertension. Am J Hypertens 1998;11:856-60.

188. Tsujita Y, Iwai N, Katsuya T, Higaki J, Ogihara T, Tamaki S, Kinoshita M, Mannami T, Ogata J, Baba S. Lack of association between genetic polymorphism of CYP11B2 and hypertension in Japanese: the Suita Study. Hypertens Res 2001;24:105-9.

189. Matsubara M, Kikuya M, Ohkubo T, Metoki H, Omori F, Fujiwara T, Suzuki M, Michimata M, Hozawa A, Katsuya T, Higaki J, Tsuji I, Araki T, Ogihara T, Satoh H, Hisamichi S, Nagai K, Kitaoka H, Imai Y. Aldosterone synthase gene (CYP11B2) C-334T polymorphism, ambulatory blood pressure and nocturnal decline in blood pressure in the general Japanese population: the Ohasama Study. J Hypertens 2001;19:2179-84.

190. Lim PO, Dow E, Brennan G, Jung RT, MacDonald TM. High prevalence of primary aldosteronism in the Tayside hypertension clinic population. J Hum Hypertens 2000;14:311-5.

191. Nicod J, Bruhin D, Auer L, Vogt B, Frey FJ, Ferrari P. A biallelic gene polymorphism of CYP11B2 predicts increased aldosterone to renin ratio in selected hypertensive patients. $J$ Clin Endocrinol Metab 2003;88:2495-500.

192. Lim PO, Macdonald TM, Holloway C, Friel E, Anderson NH, Dow E, Jung RT, Davies E, Fraser R, Connell JM. Variation at the aldosterone synthase (CYP11B2) locus contributes to hypertension in subjects with a raised aldosterone-to-renin ratio. J Clin Endocrinol Metab 2002;87:4398-402.

193. Rossi E, Regolisti G, Perazzoli F, Negro A, Davoli S, Nicoli D, Sani C, Casali B. $-344 C / T$ polymorphism of CYP11B2 gene in Italian patients with idiopathic low renin hypertension. Am J Hypertens 2001;14:934-41.

194. Tamaki S, Iwai N, Tsujita Y, Kinoshita M. Genetic polymorphism of CYP11B2 gene and hypertension in Japanese. Hypertension 1999;33:266-70.

195. Zhu H, Sagnella GA, Dong Y, Miller MA, Onipinla A, Markandu ND, MacGregor GA. Contrasting associations between aldosterone synthase gene polymorphisms and essential hypertension in blacks and in whites. J Hypertens 2003;21:87-95. 
196. Thiel BA, Chakravarti A, Cooper RS, Luke A, Lewis S, Lynn A, Tiwari H, Schork NJ, Weder AB. A genome-wide linkage analysis investigating the determinants of blood pressure in whites and African Americans. Am J Hypertens 2003;16:151-3.

197. Hunt SC, Ellison RC, Atwood LD, Pankow JS, Province MA, Leppert MF. Genome scans for blood pressure and hypertension: the National Heart, Lung, and Blood Institute Family Heart Study. Hypertension 2002;40:1-6.

198. Rice T, Rankinen T, Province MA, Chagnon YC, Perusse L, Borecki IB, Bouchard C, Rao DC. Genome-wide linkage analysis of systolic and diastolic blood pressure: the Quebec Family Study. Circulation 2000;102:1956-63.

199. von Wowern F, Bengtsson $K$, Lindgren $C M$, Orho-Melander $M$, Fyhrquist F, Lindblad U, Rastam L, Forsblom C, Kanninen T, Almgren P, Burri P, Katzman P, Groop L, Hulthen UL, Melander O. A genome wide scan for early onset primary hypertension in Scandinavians. Hum Mol Genet 2003;12:2077-81.

200. Rice T, Rankinen T, Chagnon YC, Province MA, Perusse L, Leon AS, Skinner JS, Wilmore JH, Bouchard C, Rao DC. Genomewide linkage scan of resting blood pressure: HERITAGE Family Study. Health, Risk Factors, Exercise Training, and Genetics. Hypertension 2002;39:1037-43.

201. Cooper RS, Luke A, Zhu X, Kan D, Adeyemo A, Rotimi C, Bouzekri N, Ward R, Rorimi C. Genome scan among Nigerians linking blood pressure to chromosomes 2, 3, and 19. Hypertension 2002;40:629-33.

202. Zhu DL, Wang HY, Xiong MM, He X, Chu SL, Jin L, Wang GL, Yuan WT, Zhao GS, Boerwinkle E, Huang W. Linkage of hypertension to chromosome 2q14-q23 in Chinese families. 1 Hypertens 2001;19:55-61.

203. Atwood LD, Samollow PB, Hixson JE, Stern MP, MacCluer JW. Genome-wide linkage analysis of blood pressure in Mexican Americans. Genet Epidemiol 2001;20:373-82.

204. Hsueh WC, Mitchell BD, Schneider JL, Wagner MJ, Bell CJ, Nanthakumar E, Shuldiner AR. QTL. influencing blood pressure maps to the region of $\mathrm{PPH} 1$ on chromosome 2q31-34 in Old Order Amish. Circulation 2000;101:2810-6.

205. Perola M, Kainulainen K, Pajukanta P, Terwilliger JD, Hiekkalinna T, Ellonen P, Kaprio J, Koskenvuo M, Kontula K, Peltonen L. Genome-wide scan of predisposing loci for increased diastolic blood pressure in Finnish siblings. J Hypertens 2000;18:1579-85.

206. Xu X, Rogus JJ, Terwedow HA, Yang J, Wang Z, Chen C, Niu T, Wang B, Xu H, Weiss S, Schork NJ, Fang Z. An extreme-sib-pair genome scan for genes regulating blood pressure. Am J Hum Genet 1999;64:1694-701.

207. Caulfield M, Munroe P, Pembroke J, Samani N, Dominiczak A, Brown M, Benjamin N, Webster J, Ratcliffe P, O'Shea S, Papp J, Taylor E, Dobson R, Knight J, Newhouse S, Hooper J, Lee W, Brain N, Clayton D, Lathrop GM, Farrall M, Connell J. Genome-wide mapping of human loci for essential hypertension. Lancet 2003;361:2118-23.

208. Cheng LS, Davis RC, Raffel U, Xiang AH, Wang N, Quinones M, Wen PZ, Toscano E, Diaz J, Pressman S, Henderson PC, Azen SP, Hsueh WA, Buchanan TA, Rotter J. Coincident linkage of fasting plasma insulin and blood pressure to chromosome $7 q$ in hypertensive hispanic families. Circulation 2001;104:1255-60.

209. Weder AB, Delgado MC, Zhu X, Gleiberman L, Kan D, Chakravarti A. Erythrocyte sodium-lithium countertransport and blood pressure: a genome-wide linkage study. Hypertension 2003;41: 842-6.

210. Xu X, Yang J, Rogus J, Chen C, Schork N. Mapping of a blood pressure quantitative trait locus to chromosome 15q in a Chinese population. Hum Mol Genet 1999;8:2551-5.

211. Kristjansson K, Manolescu A, Kristinsson A, Hardarson T, Knudsen H, Ingason S, Thorleifsson G, Frigge ML, Kong A, Gulcher JR, Stefansson K. Linkage of essential hypertension to chromosome 18q. Hypertension 2002;39:1044-9. 


\section{Chapter 3}

Effects of the angiotensin-converting enzyme insertion/deletion and angiotensin II type 1 receptor $\mathrm{A} 1166 \mathrm{C}$ polymorphisms on blood pressure in healthy normotensives

Léon H. Henskens, Wilko Spiering, Henri E. Stoffers, Frank L. Soomers, Robert F. Vlietinck, Peter W. de Leeuw, Abraham A. Kroon

J Hypertens 2003;21:81-6. 


\section{Abstract}

\section{Background}

Several studies have assessed the relationship between the angiotensin-converting enzyme (ACE) insertion/deletion (I/D) or angiotensin II type 1 receptor (AT1R) A1166C polymorphisms and blood pressure. Since most data have been obtained in selected populations, the present study was performed in a healthy normotensive primary care population. The objective was to investigate the individual effects of the aforementioned polymorphisms and their interaction on blood pressure.

\section{Methods}

This cross-sectional study included 203 healthy subjects. Office blood pressure was measured and polymorphisms were genotyped. Polymorphism interaction was tested using the following model: systolic blood pressure (SBP) (or diastolic blood pressure (DBP)) $=b_{0}+b_{1} X+b_{2} Y+b_{3} X Y$, in which $X$ and $Y$ represent the polymorphisms' risk alleles.

\section{Results}

The ACE I/D polymorphism was associated with SBP $(P=0.002)$ and DBP $(P=0.004)$; highest pressures tracked with the DD genotype. Furthermore, in multiple linear regression analysis the ACE D allele was associated with SBP $(P=0.005)$ and DBP $(P=0.001)$, when adjusted for body mass index and age. With respect to the AT1R A1166C polymorphism, SBP was highest in the $C C$ genotype $(P=0.025)$. In linear regression analysis the $C$ allele was not associated with SBP. No synergistic effect of ACE D and AT1R C alleles on blood pressure was found. Nevertheless, highest DBP tracked with the DDCC combination in comparison with other homozygous allele combinations $(P=0.030)$.

\section{Conclusion}

This study confirmed an association of the ACE I/D and AT1R A1166C polymorphisms with blood pressure in a healthy normotensive primary care population. Although synergistic effect of both polymorphisms on blood pressure does not seem to be present, an additive effect on DBP is likely. 


\section{Introduction}

Hypertension is a multifactorial complex trait.' Twin and family studies suggest that approximately $25 \%$ to $65 \%$ of blood pressure variations arise from genes. ${ }^{2-4}$ Since multiple transplantation studies in animals and in humans have shown that the inherited tendency to hypertension predominantly resides in the kidney, 5.6 and because the renin-angiotensin system (RAS) plays a central role in the regulation of kidney function and blood pressure, the search for genes associated with hypertension has predominantly focused on the RAS. Two well studied genetic polymorphisms of the RAS are the angiotensin-converting enzyme (ACE) insertion/deletion (I/D) polymorphism and the angiotensin II (Angll) type 1 receptor (AT1R) A1166C polymorphism. The D allele of the ACE I/D polymorphism correlates with a higher plasma ACE activity and behaves as a marker of atherosclerotic cardiovascular complications, in particular myocardial infarction." 11 Its association with hypertension, however, is not beyond dispute. ${ }^{12,13}$ On the other hand, the presence of the C allele of the AT1R A1166C polymorphism is associated with aortic stiffness ${ }^{14,15}$ and essential hypertension. ${ }^{16,17}$ Our group has shown that patients with the CC genotype exhibit increased sensitivity to Angll,18 a finding which has been corroborated by other observations. ${ }^{19}$

A synergistic relationship between the presence of the D allele of the ACE I/D polymorphism and one or two $C$ alleles of the AT1R A1166C polymorphism has been observed in terms of blood pressure variation and myocardial infarction, 20-22 but again, results are conflicting. ${ }^{23-28}$ However, most data with regard to the potential hypertensive effect of genetic polymorphisms, alone or in combination, have been obtained in selected populations, which are potentially confounded by referral bias. Furthermore, in most studies dealing with the effect of genetic polymorphisms on blood pressure, results may have been influenced by preexisting cardiovascular morbidity and antihypertensive treatment. Therefore, the present study aimed to assess the effect of the two aforementioned polymorphisms and their interaction on blood pressure in healthy normotensive subjects who were drawn from a primary care practice.

\section{Methods}

\section{Subjects}

Enrollment of subjects for this cross-sectional study started in October 1997 and lasted until January 2001. All participants were recruited from a General Practice in Kerkrade, The Netherlands. This academic group practice takes part in the Registration Network Family Practice ${ }^{29}$ which provides an interregional long-term 
and thorough recording of morbidity based on the International Classification of Primary Care. The practice has a list of $\mathbf{4 2 0 0}$ subjects, among which more than 300 patients with hypertension. All subjects included were healthy normotensive controls of an ongoing study on cardiovascular risk. Before entering the study, subjects were matched for age and sex with a chronically treated hypertensive cohort, and inclusion was validated by thorough analysis of the subjects' records combined with additional measurements of blood pressure and risk indicators. Reasons for exclusion were the presence of hypertension, diabetes mellitus, myocardial infarction, angina pectoris, cerebrovascular disease, intermittent claudication and use of cardiovascular medication.

Blood pressure was measured after 10 minutes of rest in sitting position, using a sphygmomanometer. All measurements were performed in the office by one of the authors (L.H.). Hypertension was defined as systolic blood pressure (SBP) $\geq 160$ $\mathrm{mmHg}$ and/or diastolic blood pressure $(D B P) \geq 95 \mathrm{mmHg}$ according to the Guidelines on Hypertension for Dutch General Practitioners. ${ }^{30}$ Blood samples were drawn for serum creatinine, uric acid, total cholesterol and glucose levels. Creatinine clearance was calculated using Cockcroft's formula. ${ }^{31}$

Participants gave informed consent and the study was approved by the Medical Ethics Committee of the University Hospital Maastricht.

\section{Genetic analysis}

DNA was extracted from whole blood using the QIAamp Blood Kit (Qiagen Inc., Valencia, CA, USA). The ACE I/D polymorphism was detected using the technique described by Rigat et al. ${ }^{32}$ A second PCR was performed to avoid misidentification of ID as DD. ${ }^{33}$ The AT1R A1166C polymorphism was genotyped by means of mutagenically separated PCR, as described earlier. ${ }^{18}$

\section{Statistical analysis}

Differences between genotype groups were tested with One-Way analysis of variance (ANOVA), using Bonferroni's method for post hoc multiple comparisons between genotype classes. Genotype frequencies between groups were compared using a Chi-Square test and tests for Hardy-Weinberg equilibrium were carried out using standard methods. ${ }^{34}$ With linear regression analysis determinants of blood pressure were investigated. Effects of the genotypes, represented by dummy-variables, were assessed using the deviation from mean coding approach. ${ }^{35}$ The interaction between both polymorphisms on blood pressure was tested using the following model: SBP (or DBP) $=b_{0}+b_{1} X+b_{2} Y+$ $b_{3} X Y$, in which $b$ represents a constant variable, $X$ the risk allele of polymorphism $X, Y$ the risk allele of polymorphism $Y$, and $X Y$ the interaction between the two. A post hoc analysis, in which subjects were divided in a true normotensive group 
(SBP<130 $\mathrm{mmHg}$ and $\mathrm{DBP}<85 \mathrm{mmHg}$ ) and a borderline hypertensive group ( $S B P \geq 130 \mathrm{mmHg}$ and $\mathrm{DBP} \geq 85 \mathrm{mmHg}$ ), was carried out to assess whether associations were similar or not in both groups. The study had a power of 0.8 to detect a difference between groups of 10 and $5 \mathrm{mmHg}$ in mean SBP and DBP, respectively. Unless indicated otherwise, data are expressed as means \pm standard error of the mean (SEM). A P-value less than 0.05 was considered statistically significant. Statistical analyses were performed using SPSS 11.0 for Windows (SPSS Inc., Chicago, IL, USA).

\section{Results}

\section{General characteristics}

Altogether, 203 subjects were included in the study. Characteristics of the study population genotyped for the ACE I/D and the AT1R A1166C polymorphisms are summarized in Table 3.1 and Table 3.2, respectively. The determination of the genotypes failed in 6 subjects for the ACE I/D polymorphism and in 5 subjects for the AT1R A1166C polymorphism. So, in 197 subjects both polymorphisms were successfully determined. With respect to the ACE I/D polymorphism no significant differences between the three different genotypes were found, with the exception of uric acid concentration, which was higher in DD subjects compared to ID subjects $(P<0.05$; Table 3.1$)$. With respect to the AT1R A1166C polymorphism, cholesterol levels were higher in AA subjects compared to AC subjects $(P<0.05)$, but otherwise no significant differences between genotypes were found (Table 3.2). Genotype frequencies of both polymorphisms were in Hardy-Weinberg equilibrium.

\section{Blood pressure and separate polymorphisms}

For the ACE I/D polymorphism SBP and DBP were significantly different between the genotype groups, $P=0.002$ and $P=0.004$, respectively (Table 3.1 ). Post hoc comparison of the ACE genotype classes showed a significantly higher SBP in DD homozygotes (138 $\pm 2 \mathrm{mmHg}$ ) compared to both ID heterozygotes $(130 \pm 1 \mathrm{mmHg}$, $P=0.002)$. The difference between $D D$ and II homozygotes $(132 \pm 2 \mathrm{mmHg})$ was borderline significant: $P=0.08$. DBP was significantly higher in DD homozygotes $(81 \pm 1 \mathrm{mmHg})$ compared to both ID heterozygotes $(77 \pm 1 \mathrm{mmHg}, P=0.006)$ and II homozygotes $(77 \pm 1 \mathrm{mmHg}, P=0.015)$. In simple linear regression analysis body mass index $(\mathrm{BMI})$ and age proved to be independent predictors of blood pressure. Multiple linear regression analysis confirmed the association of the ACE D allele with SBP ( $\left.R^{2}=0.048 ; P=0.005\right)$ and $D B P\left(R^{2}=0.058 ; P=0.001\right)$ when adjusted for $B M I$ and age. This was also true for both SBP $(\beta=0.291 ; P<0.001)$ and $D B P(\beta=0.238$; $P=0.001$ ) when using the deviation from mean coding approach. No association 
between the ACE D allele and BMI or age was found. In the post hoc analysis these associations were found in both the normotensive group and in the group of subjects with borderline hypertension.

Table 3.1. Characteristics of the study population genotyped for the ACE I/D polymorphism.

\begin{tabular}{|c|c|c|c|c|}
\hline Parameter & II & ID & DD & Pvalue: \\
\hline Number, $n$ (\%) & $46(23.4)$ & $98(49.7)$ & $53(26.9)$ & $0.999 b$ \\
\hline Males/females, $n$ & $17 / 29$ & $46 / 52$ & $30 / 23$ & $0.148^{b}$ \\
\hline Age, years & $63 \pm 2$ & $65 \pm 1$ & $62 \pm 2$ & 0.291 \\
\hline $\mathrm{BMI}, \mathrm{kg} / \mathrm{m}^{2}$ & $27.3 \pm 0.6$ & $26.9 \pm 0.5$ & $27.4 \pm 0.7$ & 0.765 \\
\hline Waist/hip ratio & $0.92 \pm 0.01$ & $0.92 \pm 0.01$ & $0.92 \pm 0.01$ & 0.993 \\
\hline $\mathrm{SBP}, \mathrm{mmHg}$ & $132 \pm 2$ & $130 \pm 1$ & $138 \pm 2^{t}$ & 0.002 \\
\hline $\mathrm{DBP}, \mathrm{mmHg}$ & $77 \pm 1$ & $77 \pm 1$ & $81 \pm 1^{* 1}$ & 0.004 \\
\hline Heart rate, beats $/ \mathrm{min}$ & $75 \pm 2$ & $75 \pm 1$ & $75 \pm 1$ & 0.997 \\
\hline Smoking, packyears & $21.3 \pm 4.2$ & $26.9 \pm 3.3$ & $25.9 \pm 5.1$ & 0.646 \\
\hline $\mathrm{CC}, \mathrm{mL} / \mathrm{min}$ & $81.2 \pm 3.6$ & $74.9 \pm 2.7$ & $79.3 \pm 3.5$ & 0.328 \\
\hline Uric acid, $\mathrm{mmol} / \mathrm{L}$ & $0.30 \pm 0.01$ & $0.29 \pm 0.01$ & $0.33 \pm 0.01$ & 0.011 \\
\hline Cholesterol, $\mathrm{mmol} / \mathrm{L}$ & $5.54 \pm 0.16$ & $5.69 \pm 0.13$ & $5.72 \pm 0.15$ & 0.701 \\
\hline Glucose, $\mathrm{mmol} / \mathrm{L}$ & $5.85 \pm 0.26$ & $5.51 \pm 0.09$ & $5.72 \pm 0.14$ & 0.224 \\
\hline
\end{tabular}

Subjects with the CC genotype of the AT1R A1166C polymorphism had a significantly higher SBP compared to AC subjects $(141 \pm 3 \mathrm{mmHg}$ vs. $131 \pm 2 \mathrm{mmHg}$, $P=0.02$, Table 3.2). However, after adjustment for $B M I$ and age no association was found between the AT1R C allele and SBP. This was also true when the normotensive and borderline hypertensive group were considered respectively.

\section{Interaction of both polymorphisms}

Table 3.3 shows the interaction of the ACE I/D and the AT1R A1166C alleles on blood pressure in this population. No interaction of the ACE D and the AT1R C alleles on SBP $(P=0.475)$ or DBP $(P=0.688)$ was found in the linear regression model for interaction as described above. Since this finding does not exclude an additive effect of both alleles and because there is uncertainty with respect to the pattern of inheritance (recessive, co-dominant or dominant), we decided to re-analyse these data using homozygous allele combinations only, i.e. IIAA, IICC, DDAA and DDCC. With this approach, we found that the highest DBP tracked with the homozygous DDCC allele combination (Figure 3.1) when compared to the other homozygous allele combinations $(P=0.03)$. 
Table 3.2. Characteristics of the study population genotyped for the ATIR A1166C polymorphism.

\begin{tabular}{|c|c|c|c|c|}
\hline Parameter & AA & $A C$ & $\mathrm{CC}$ & Avalue* \\
\hline Number, $n(\%)$ & $104(52.5)$ & $77(38.9)$ & $17(8.6)$ & $0.879 b$ \\
\hline Males/females, $n$ & $53 / 51$ & $33 / 44$ & $8 / 9$ & $0.558^{\circ}$ \\
\hline Age, years & $65 \pm 1$ & $63 \pm 1$ & $62 \pm 3$ & 0.312 \\
\hline $\mathrm{BMI}, \mathrm{kg} / \mathrm{m}^{2}$ & $26.8 \pm 0.5$ & $27.0 \pm 0.5$ & $28.6 \pm 0.9$ & 0.303 \\
\hline Waist/hip ratio & $0.92 \pm 0.01$ & $0.91 \pm 0.01$ & $0.95 \pm 0.02$ & 0.395 \\
\hline $\mathrm{SBP}, \mathrm{mmHg}$ & $133 \pm 1$ & $131 \pm 2$ & $141 \pm 3$ & 0.025 \\
\hline $\mathrm{DBP}, \mathrm{mmHg}$ & $78 \pm 1$ & $78 \pm 1$ & $78 \pm 2$ & 0.963 \\
\hline Heart rate, beats $/$ min & $76 \pm 1$ & $74 \pm 1$ & $73 \pm 3$ & 0.551 \\
\hline Smoking, packyears & $30.4 \pm 3.9$ & $21.3 \pm 3.1$ & $24.5 \pm 4.2$ & 0.172 \\
\hline $\mathrm{CC}, \mathrm{mL} / \mathrm{min}$ & $76.0 \pm 2.8$ & $78.0 \pm 2.8$ & $83.1 \pm 4.6$ & 0.524 \\
\hline Uric acid, $\mathrm{mmo} / \mathrm{l}$ & $0.30 \pm 0.01$ & $0.29 \pm 0.01$ & $0.33 \pm 0.02$ & 0.324 \\
\hline Cholesterol, $\mathrm{mmol} / \mathrm{L}$ & $5.83 \pm 0.11$ & $5.36 \pm 0.14^{*}$ & $5.94 \pm 0.27$ & 0.016 \\
\hline Glucose, $\mathrm{mmol} / \mathrm{L}$ & $5.61 \pm 0.11$ & $5.64 \pm 0.16$ & $5.85 \pm 0.11$ & 0.709 \\
\hline
\end{tabular}

Table 3.3. Interaction of ACE I/D and AT1R A1166C polymorphisms on blood pressure.

\begin{tabular}{|c|c|c|c|c|}
\hline \multirow[b]{2}{*}{ ACE I/D } & & \multicolumn{3}{|c|}{ AT1R A1166C } \\
\hline & & AA & AC & cC \\
\hline \multirow[t]{2}{*}{ ॥ } & SBP & $133 \pm 4$ & $128 \pm 3$ & $145 \pm 5$ \\
\hline & DBP & $76 \pm 1$ & $77 \pm 2$ & $78 \pm 3$ \\
\hline \multirow[t]{2}{*}{ ID } & SBP & $130 \pm 2$ & $129 \pm 3$ & $138 \pm 6$ \\
\hline & DBP & $78 \pm 1$ & $77 \pm 1$ & $73 \pm 3$ \\
\hline \multirow[t]{2}{*}{ DD } & SBP & $140 \pm 2$ & $135 \pm 3$ & $141 \pm 5$ \\
\hline & DBP & $81 \pm 1$ & $80 \pm 2$ & $82 \pm 3$ \\
\hline
\end{tabular}

SBP: systolic blood pressure; DBP: diastolic blood pressure. All pressures expressed in $\mathrm{mmHg}$.

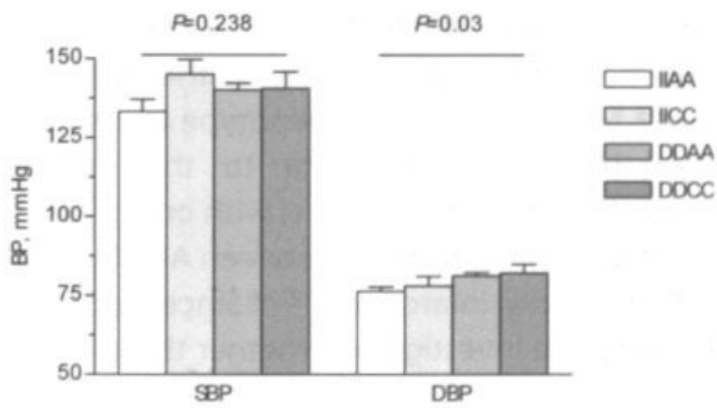

Figure 3.1. Effects of homozygous allele combinations of the ACE I/D and AT1R A1166C polymorphisms on blood pressure. 


\section{Discussion}

In the present study we investigated the individual and interactive influences of two polymorphisms of the RAS in normotensive healthy subjects drawn from a primary care setting. Our data show an association of the ACE I/D polymorphism with both SBP and DBP and a relation of the AT1R A1166C polymorphism with SBP only. Whereas there does not seem to be synergy between both polymorphisms, our results indicate an additive effect on DBP, as the highest pressure tracked with the presence of two D alleles of the ACE gene in combination with two AT1R C alleles.

Several studies investigated the association between the ACE I/D polymorphism and blood pressure, yielding conflicting results. ${ }^{8,10.36-41}$ However, most negative studies assessed the association by taking hypertension as a qualitative trait, rather than using blood pressure as a continuous, quantitative trait. 10,39,41 Furthermore, results could have been influenced by pre-existing cardiovascular morbidity and medication influencing blood pressure (since the majority of studies was conducted in hypertensive populations) and, potentially, by referral bias. The association between ACE genotype and blood pressure in the present study is in agreement with the findings by Uemura et al. ${ }^{37}$ and data from the Framingham Heart Study. ${ }^{36}$ Recently, a Japanese study ${ }^{38}$ reported identical results, suggesting that the action of the polymorphism may be homogeneous throughout ethnic groups. Since it has been shown that the $D$ allele is associated with higher levels of $A C E,{ }^{42}$ an association of the ACE I/D polymorphism with blood pressure could be explained by an increase in local Angll levels. So far, however, no study has provided evidence to support this notion.

Although in the present study highest SBP tracked with CC homozygosity for the AT1R A1166C polymorphism, the C allele was not significantly associated with SBP in linear regression analysis. Nevertheless, Hingorani et al.43 observed a significantly higher SBP and DBP in the presence of two AT1R C alleles. Others also found an association of the AT1R A1166C polymorphism with essential hypertension and aortic stiffness, particularly in the face of increased SBP.14-17 Moreover, our group ${ }^{18}$ found that the CC genotype is associated with increased sensitivity to Angll. This may contribute to the increased incidence of cardiovascular abnormalities found in subjects with one or two C alleles.

Several studies have shown an interaction between ACE D and ATIR C alleles with respect to the risk of myocardial infarction. ${ }^{20-22,44}$ Since blood pressure also may be related to multiple genes, we investigated whether there is a synergistic effect of the ACE D and ATIR C alleles on blood pressure. An interaction in the sense of synergy, however, was not present in our population. Nevertheless, an additive effect was found. Analysing only homozygous allele combinations, we found an 
effect of both genes on DBP with the highest pressure in subjects with the DDCC allele combination. The effect was most pronounced when adding an ACE D allele (IIAA vs. DDAA and IICC vs. DDCC), but, also the addition of an ATIR C allele (IIAA vs. IICC and DDAA vs. DDCC) seemed to increase DBP. This is more or less in line with a recently published prospective study's that found an 'epistatic' interaction of the ACE I/D polymorphism with both the aldosterone synthase and $\alpha$-adducin polymorphisms on the development of hypertension. Particularly in the case of homozygosity of the ACE D allele, the risk of developing hypertension during 12 years of follow-up increased significantly.

In conclusion, this study confirmed an association of the ACE I/D polymorphism on blood pressure in a healthy normotensive primary care population. A synergistic effect between the ACE I/D and the AT1R A1166C polymorphisms on blood pressure could not be shown, though an additive effect on DBP is very likely. This study supports the notion that further research is necessary to explore the role of multiple genetic markers with respect to cardiovascular risk in a general population. 


\section{References}

1. Lander ES, Schork NJ. Genetic dissection of complex traits. Science 1994;265:2037-48.

2. Borhani NO, Feinleib M, Garrison RJ, Christian JC, Rosenman RH. Genetic variance in blood pressure. Acta Genet Med Gemellol (Roma) 1976;25:137-44.

3. Rice T, Vogler GP, Perusse L, Bouchard C, Rao DC. Cardiovascular risk factors in a French Canadian population: resolution of genetic and familial environmental effects on blood pressure using twins, adoptees, and extensive information on environmental correlates. Genet Epidemiol 1989;6:571-88.

4. Smith TW, Turner CW, Ford MH, Hunt SC, Barlow GK, Stults BM, Williams RR. Blood pressure reactivity in adult male twins. Health Psychol 1987;6:209-20.

5. Woolfson RG, de Wardener HE. Primary renal abnormalities in hereditary hypertension. Kidney Int 1996:50:717-31.

6. Guidi E, Menghetti D, Milani S, Montagnino G, Palazzi P, Bianchi G. Hypertension may be transplanted with the kidney in humans: a long-term historical prospective follow-up of recipients grafted with kidneys coming from donors with or without hypertension in their families. J Am Soc Nephrol 1996;7:1131-8.

7. Tiret L, Rigat B, Visvikis S, Breda C, Corvol P, Cambien F, Soubrier F. Evidence, from combined segregation and linkage analysis, that a variant of the angiotensin I-converting enzyme (ACE) gene controls plasma ACE levels. Am J Hum Genet 1992;51:197-205.

8. Cambien F. The angiotensin-converting enzyme (ACE) genetic polymorphism: its relationship with plasma ACE level and myocardial infarction. Clin Genet 1994;46:94-101.

9. Samani NJ, Thompson JR, O'Toole L, Channer K, Woods KL. A meta-analysis of the association of the deletion allele of the angiotensin-converting enzyme gene with myocardial infarction. Circulation 1996;94:708-12.

10. Agerholm-Larsen B, Nordestgaard BG. Tybjaerg-Hansen A. ACE gene polymorphism in cardiovascular disease: meta-analyses of small and large studies in whites. Arterioscler Thromb VasC Biol 2000;20:484-92.

11. Keavney B, McKenzie C, Parish S, Paimer A, Clark S, Youngman L, Delepine M, Lathrop M, Peto R, Collins R. Large-scale test of hypothesised associations between the angiotensin-convertingenzyme insertion/deletion polymorphism and myocardial infarction in about 5000 cases and 6000 controls. International Studies of Infarct Survival (ISIS) Collaborators. Lancet 2000;355:43442.

12. Staessen JA, Wang JG, Ginocchio G, Petrov V, Saavedra AP, Soubrier F, Vlietinck R, Fagard R. The deletion/insertion polymorphism of the angiotensin converting enzyme gene and cardiovascular-renal risk. J Hypertens 1997;15:1579-92.

13. Tiret L, Blanc $H$, Ruidavets JB, Arveiler $D$, Luc $G$, Jeunemaitre $X$, Tichet J, Mallet $C$, Poirier $O$, Plouin $\mathrm{PF}$, Cambien $\mathrm{F}$. Gene polymorphisms of the renin-angiotensin system in relation to hypertension and parental history of myocardial infarction and stroke: the PEGASE study. Projet d'Etude des Genes de I'Hypertension Arterielle Severe a moderee Essentielle. J Hypertens 1998;16:37-44.

14. Benetos A, Topouchian J, Ricard S, Gautier S, Bonnardeaux A, Asmar R, Poirier O, Soubrier F, Safar $\mathrm{M}$, Cambien $\mathrm{F}$. Influence of angiotensin II type 1 receptor polymorphism on aortic stiffness in never-treated hypertensive patients. Hypertension 1995;26:44-7.

15. Benetos A, Gautier S, Ricard S, Topouchian J, Asmar R, Poirier O, Larosa E, Guize L, Safar M, Soubrier F, Cambien F. Influence of angiotensin-converting enzyme and angiotensin II type 1 receptor gene polymorphisms on aortic stiffness in normotensive and hypertensive patients. Circulation 1996;94:698-703.

16. Bonnardeaux A, Davies E, Jeunemaitre X, Fery I, Charru A, Clauser E, Tiret L, Cambien F, Corvol P, Soubrier F. Angiotensin II type 1 receptor gene polymorphisms in human essential hypertension. Hypertension 1994:24:63-9.

17. Wang WY, Zee RY, Morris BJ. Association of angiotensin II type 1 receptor gene polymorphism with essential hypertension. Clin Genet 1997;51:31-4. 
18. Spiering W, Kroon AA, Fuss-Lejeune MM, Daemen MU, de Leeuw PW. Angiotensin II sensitivity is associated with the angiotensin II type 1 receptor $A(1166) C$ polymorphism in essential hypertensives on a high sodium diet. Hypertension 2000;36:411-6.

19. van Geel PP, Pinto YM, Voors AA, Buikema H, Oosterga M, Crijns HJ, van Gilst WH. Angiotensin II type 1 receptor $\mathrm{A} 1166 \mathrm{C}$ gene polymorphism is associated with an increased response to angiotensin II in human arteries. Hypertension 2000;35:717-21.

20. Tiret L, Bonnardeaux A, Poirier O, Ricard S, Marques-Vidal P, Evans A, Arveiler D, Luc G, Kee F, Ducimetiere P, et al. Synergistic effects of angiotensin-converting enzyme and angiotensin- 11 type 1 receptor gene polymorphisms on risk of myocardial infarction. Lancet 1994;344:910-3.

21. Alvarez R, Reguero JR, Batalla A, Iglesias-Cubero G, Cortina A, Alvarez V, Coto E. Angiotensinconverting enzyme and angiotensin II receptor 1 polymorphisms: association with early coronary disease. Cardiovasc Res 1998:40:375-9.

22. Fatini C, Abbate R, Pepe G, Battaglini B, Gensini F, Ruggiano G, Gensini GF, Guazzelli R. Searching for a better assessment of the individual coronary risk profile. The role of angiotensin-converting enzyme, angiotensin II type 1 receptor and angiotensinogen gene polymorphisms. Eur Heart $J$ 2000;21:633-8.

23. Zee RY, Lou YK, Griffiths LR, Morris BJ. Association of a polymorphism of the angiotensin Iconverting enzyme gene with essential hypertension. Biochem Biophys Res Commun 1992;184: 9-15.

24. Castellano M, Muiesan ML, Beschi M, Rizzoni D, Cinelli A, Salvetti M, Pasini G, Porteri E, Bettoni G, Zulli R, Agabiti-Rosei E. Angiotensin II type 1 receptor A/C1166 polymorphism. Relationships with blood pressure and cardiovascular structure. Hypertension 1996;28:1076-80.

25. Schmidt S, Beige J, Walla-Friedel M, Michel MC, Sharma AM, Ritz E. A polymorphism in the gene for the angiotensin II type 1 receptor is not associated with hypertension. $J$ Hypertens 1997;15: $1385-8$.

26. Gardemann A, Nguyen QD, Humme J, Stricker J, Katz N, Tillmanns H, Hehrlein FW, Rau M, Haberbosch W. Angiotensin II type 1 receptor A1166C gene polymorphism. Absence of an association with the risk of coronary artery disease and myocardial infarction and of a synergistic effect with angiotensin-converting enzyme gene polymorphism on the risk of these diseases. Eur Heart J 1998;19:1657-65.

27. Stefansson B, Ricksten A, Rymo L, Aurell M, Herlitz H. Angiotensin-converting enzyme gene I/D polymorphism in malignant hypertension. Blood Press 2000;9:104-9.

28. Steeds RP, Wardle A, Smith PD, Martin D, Channer KS, Samani NJ. Analysis of the postulated interaction between the angiotensin II sub-type 1 receptor gene A1166C polymorphism and the insertion/deletion polymorphism of the angiotensin converting enzyme gene on risk of myocardial infarction. Atherosclerosis 2001;154:123-8.

29. Metsemakers JF, Hoppener P, Knottnerus JA, Kocken RJ, Limonard CB. Computerized health information in The Netherlands: a registration network of family practices. $\mathrm{Br} J \mathrm{Gen}$ Pract 1992;42:102-6.

30. Walma EP, Grundmeijer HG, Thomas S, Prins A, van den Hoogen JP, van der Laan JR. NHGstandaard hypertensie. Huisarts Wet 1997;40:598-617.

31. Cockcroft DW, Gault MH. Prediction of creatinine clearance from serum creatinine. Nephron 1976;16:31-41.

32. Rigat B, Hubert C, Corvol P, Soubrier F. PCR detection of the insertion/deletion polymorphism of the human angiotensin converting enzyme gene (DCP1) (dipeptidyl carboxypeptidase 1). Nucleic Acids Res 1992;20:1433.

33. Shanmugam V, Sell KW, Saha BK. Mistyping ACE heterozygotes. PCR Methods Appl 1993;3:120-1.

34. Falconer DS. Introduction to quantitative genetics. 3rd ed. Essex: Longman; 1989.

35. Hosmer DW, Lemeshow S. Interpretation of the fitted logistic regression model. In: Applied logistic regression. 2nd ed. New York: Wiley-Interscience; 2000:47-90.

36. O'Donnell CJ, Lindpaintner K, Larson MG, Rao VS, Ordovas JM, Schaefer EJ, Myers RH, Levy D. Evidence for association and genetic linkage of the angiotensin-converting enzyme locus with hypertension and blood pressure in men but not women in the Framingham Heart Study. Circulation 1998;97:1766-72. 
37. Uemura K, Nakura J, Kohara K, Miki T. Association of ACE I/D polymorphism with cardiovascular risk factors. Hum Genet 2000;107:239-42.

38. Zaman MM, Yoshiike N, Date C, Yokoyama T, Matsumura Y, Ikemoto S, Tanaka H. Angiotensin converting enzyme genetic polymorphism is not associated with hypertension in a crosssectional sample of a Japanese population: the Shibata Study.J Hypertens 2001;19:47-53.

39. Jeunemaitre X, Lifton RP, Hunt SC, Williams RR, Lalouel JM. Absence of linkage between the angiotensin converting enzyme locus and human essential hypertension. Nat Genet 1992;1:72-5.

40. Berge KE, Berg K. No effect of insertion/deletion polymorphism at the ACE locus on normal blood pressure level or variability. Clin Genet 1994;45:169-74.

41. Kiema TR, Kauma H, Rantala AO, Lilja M, Reunanen A, Kesaniemi YA, Savolainen MJ. Variation at the angiotensin-converting enzyme gene and angiotensinogen gene loci in relation to blood pressure. Hypertension 1996;28:1070-5.

42. Rigat B, Hubert C, Alhenc-Gelas F, Cambien F, Corvol P, Soubrier F. An insertion/deletion polymorphism in the angiotensin l-converting enzyme gene accounting for half the variance of serum enzyme levels. J Clin Invest 1990;86:1343-6.

43. Hingorani AD, Jia $H$, Stevens PA, Hopper R, Dickerson JE, Brown MJ. Renin-angiotensin system gene polymorphisms influence blood pressure and the response to angiotensin converting enzyme inhibition. J Hypertens 1995;13:1602-9.

44. Rice GI, Foy CA, Grant PJ. Angiotensin converting enzyme and angiotensin II type 1-receptor gene polymorphisms and risk of ischaemic heart disease. Cardiovasc Res 1999;41:746-53.

45. Staessen JA, Wang JG, Brand E, Barlassina C, Birkenhager WH, Herrmann SM, Fagard R, Tizzoni L, Bianchi G. Effects of three candidate genes on prevalence and incidence of hypertension in a Caucasian population. J Hypertens 2001;19:1349-58. 


\section{Chapter 4}

\section{Genetic influences on twenty-four hour blood pressure profiles in a hypertensive population}

Wilko Spiering, Sergio A. Rodríguez Hernández, Abraham A. Kroon, Iris M. Zwaan, Peter W. de Leeuw 


\section{Abstract}

\section{Background}

Data on the association of the angiotensin-converting enzyme (ACE) insertion/deletion (I/D) and angiotensin II type 1 receptor (AT1R) A1166C polymorphisms with hypertension are conflicting. In most studies, however, the qualitative phenotype (hypertension), rather than the quantitative phenotype (the level of blood pressure (BP)) was used. Furthermore, most studies have focused on office BP only. The objective was to investigate the association of BP with the ACE I/D and AT1R A1166C polymorphisms by means of both office and ambulatory blood pressure monitoring (ABPM).

\section{Methods}

From 348 hypertensive patients in whom 24 hour BP profiles were measured with a Spacelabs 90207 device, BP data were analysed. The ACE I/D and AT1R A1166C polymorphism were determined using PCR.

\section{Results}

Office BP did not differ between the various ACE or AT1R genotype groups. However, ambulatory BP (systolic, diastolic, and mean) and BP load were positively associated with the ACE I/D polymorphism. This was true for values obtained during the initial hour, as well as for those during daytime (9:00 AM-9:00 PM), nighttime (1:00 AM-6:00 AM) and 24 hours. An 'allele dose effect' for both BP and BP load was found. There were no differences in heart rate, BP variability, and amount of dipping. The AT1R A1166C polymorphism showed no consistent association with blood pressure (load).

\section{Conclusion}

From these data we conclude that frequent measuring of blood pressure by ABPM is crucial to find an association of the ACE D allele with various aspects of blood pressure. 


\section{Introduction}

Given the pivotal role of angiotensin II (AngII) in blood pressure regulation, the genes coding for angiotensin-converting enzyme (ACE) and the angiotensin II type 1 receptor (AT1R) are among the prime candidates to determine the severity of hypertension. Indeed, some studies have found a positive association between the ACE insertion/deletion (I/D) polymorphism and hypertension. ${ }^{1,2}$ Other studies, however, failed to confirm this association. ${ }^{3.4} \mathrm{~A}$ meta-analysis by Staessen et al. led to the conclusion that the $D$ allele of this polymorphism is not associated with hypertension per se, but rather behaves as a marker of atherosclerotic cardiovascular complications. ${ }^{5}$ Fewer studies have addressed the association between the AT1R A1166C polymorphism with blood pressure, and these also showed conflicting results. ${ }^{6.8}$

However, most of these studies assessed associations by taking hypertension as a qualitative trait, rather than using blood pressure as a continuous quantitative trait. Moreover, in almost all studies office blood pressure measurements were used, instead of more informative 24 hour ambulatory blood pressure measurements (ABPM).

Since ABPM data correlate better with target organ damage than does blood pressure determined in the examiners office, ${ }^{9-11}$ one could hypothesize that ABPM data are also superior to office measurements for evaluating the possible association between blood pressure and the ACE I/D and AT1R A1166C polymorphisms. ABPM has the additional advantage of providing detailed information about blood pressure load, variability, and dipping. Therefore, in the present study we investigated the association of the ACE I/D and AT1R A1166C polymorphisms with both office and ambulatory blood pressure measurements in treated and untreated essential hypertensive patients. We also assessed the association of other ABPM derivatives like blood pressure load, variability, and dipping with these polymorphisms. Finally, we tested whether such associations are gender dependent, as was suggested by some recent studies.12,13

\section{Methods}

\section{Patients}

Patients were selected from our outpatient department in a 14 months period. They were drawn from a larger group of patients, all of whom had been referred to our clinic for evaluation of their hypertension. As part of the work-up we routinely perform 24 hour ABPM in such patients to exclude 'white coat' hypertension. To be eligible for the present study, patients had to have 
uncomplicated essential hypertension without comorbid conditions. Patients with proven renal artery stenosis on renal angiography were excluded. Altogether, 348 patients qualified for inclusion in the study and all gave written informed consent to participate. ABPM measurements were performed in 144 untreated patients and 204 patients who used blood pressure modifying drugs (BPMD, i.e. either antihypertensives or other agents that could potentially influence blood pressure such as non-steroidal anti-inflammatory drugs). The study was approved by the Medical Ethics Committee of the University Hospital Maastricht.

\section{Blood pressure measurements}

Office blood pressure measurements as used in this study were based on the average of three duplicate readings obtained during the last three visits to the clinic prior to ABPM. Patients were always seen by their own doctor. Measurements were performed in the seating position after 10 minutes of rest. After these three visits ABPM was performed using the SpaceLabs 90207 device (SpaceLabs ${ }^{\mathrm{T} M}$, Redmond, WA, USA). Patients were always monitored during normal daily activity. For calibration, the device was connected to a mercury sphygmomanometer with an Y-tube. Three consecutive measurements were taken, 2 to 3 minutes apart, in a seated position, and calibrated to the monitor readings. The device was used only if measurements differed by $\leq 5 \mathrm{mmHg}$. from the sphygmomanometer. Ambulatory blood pressure recordings were obtained every 15 minutes during daytime (7:00 AM-11:00 PM) and every 30 minutes during nighttime (11:00 PM-7:00 AM). Blood pressure data were transferred into a personal computer and analysed by the dabl" ABPM program (ECF Medical Ltd., Dublin, Ireland) for the following derivatives: time weighted mean blood pressure, load, leese, blood pressure variability (standard deviation of mean blood pressure, coefficient of variation, root mean square of successive deviations), number of load events, number of leese events, maximum load duration, and maximum leese duration. All these variables were calculated for the initial hour, daytime (defined as the period from 9:00 AM to 9:00 PM less the initial hour), and nighttime (defined as the period from 1:00 AM to 6:00 AM). Mean, load, and leese were also determined for the entire 24 hour period. Lastly, the percentage dipping was calculated. All analyses were applied to systolic blood pressure (SBP), diastolic blood pressure (DBP), mean blood pressure (MBP), pulse pressure (PP), and heart rate (HR), but only when data were valid (i.e. when $M B P>0$ and $S B P>M B P>D B P$ ). For definition of these variables see appendix.

\section{Genetic analysis}

DNA was extracted from whole blood using the QIAamp ${ }^{5}$ Blood Kit (Qiagen Inc., Valencia, CA, USA). The ACE I/D polymorphism was detected using the technique described by Rigat et al. ${ }^{14} \mathrm{~A}$ second PCR was performed to avoid misidentification 
of ID as DD.15 The AT1R A1166C polymorphism was genotyped by means of mutagenically separated PCR, as described earlier. ${ }^{16}$

\section{Statistical analysis}

The calculation of allele frequencies to test for Hardy-Weinberg equilibrium was carried out using standard methods ${ }^{17}$ and Chi-Square test was used to compare expected with observed frequencies. One-Way analysis of variance (ANOVA) was used to compare differences between the genotype groups of each polymorphism. When this revealed significant differences, data were further tested by post hoc comparisons with Bonferroni correction for multiple testing to assess between which groups significant differences existed. To explore the possible inheritance model, data were analysed assuming either a recessive (II+ID vs. $D D$ or $A A+A C$ vs. $C C$ ), an additive (II vs. ID vs. $D D$ or $A A$ vs. $A C$ vs. $C C$ ), or a dominant (II vs. ID+DD or $A A$ vs. $A C+C C$ ) effect of the $D$ allele and $C$ allele, respectively. The study had a power of 0.9 to detect a difference in mean 24 hour blood pressure of $3 \mathrm{mmHg}$ between groups. Results are expressed as means \pm standard error of the mean (SEM). A P-value of less than 0.05 was considered to be statistically significant. Statistical analyses were performed using SPSS 11.0 for Windows (SPSS Inc., Chicago, IL, USA).

\section{Results}

\section{Baseline characteristics}

The baseline characteristics of the genotype groups of the ACE I/D and the AT1R A1166C polymorphisms are summarized in Table 4.1 and 4.2 , respectively. The genotype groups of both polymorphisms were in Hardy-Weinberg equilibrium. With respect to both polymorphisms patients in the various genotype groups were comparable for age, gender, treatment status, and renal function (as assessed by serum creatinine). Body mass index (BMI), however, was significantly higher in the DD patients compared to the other groups. Importantly, systolic and diastolic office blood pressures did not differ between the various genotype groups.

\section{ACE I/D polymorphism and ABPM data}

\section{Initial hour}

During the first hour of blood pressure registration, a significant effect of genotype was demonstrable on DBP (Figure 4.1B), a borderline significant effect on SBP ( $P=0.09$; Figure 4.1A) and MBP $(P=0.06)$, and not on PP and HR. In the post hoc comparison DBP was significantly higher in DD patients than in ID (104 \pm 1 vs. 
$100 \pm 1 \mathrm{mmHg} ; P<0.05$; Figure 4.1B), and than in II patients $(104 \pm 1$ vs. $99 \pm 2 \mathrm{mmHg}$; $P<0.05$; Figure 4.1B). Diastolic blood pressure load as well as maximum diastolic load duration were also significantly higher in DD as compared to ID and II patients.

Table 4.1. Characteristics of the study population with respect to ACE I/D polymorphism.

\begin{tabular}{|c|c|c|c|c|}
\hline & Total & II & ID & DD \\
\hline Number, $\boldsymbol{n}(\%)$ & $348(100)$ & $72(20.7)$ & $168(48.3)$ & $108(31.0)$ \\
\hline Males/females, $\boldsymbol{n}$ & $125 / 223$ & $24 / 48$ & $56 / 112$ & $45 / 63$ \\
\hline Treated/untreated, $n$ & $204 / 144$ & $39 / 33$ & $105 / 63$ & $60 / 48$ \\
\hline Age, years & $53 \pm 1$ & $51 \pm 2$ & $54 \pm 1$ & $53 \pm 1$ \\
\hline $\mathrm{BMI}, \mathrm{kg} / \mathrm{m}^{2}$ & $27.7 \pm 0.3$ & $26.6 \pm 0.4$ & $27.2 \pm 0.5$ & $29.5 \pm 0.7^{*+}$ \\
\hline Creatinine, $\mu \mathrm{mol} / \mathrm{L}$ & $86 \pm 1$ & $84 \pm 3$ & $86 \pm 2$ & $86 \pm 2$ \\
\hline Office SBP, $m m H g$ & $168 \pm 2$ & $165 \pm 3$ & $171 \pm 2$ & $166 \pm 3$ \\
\hline Office DBP, $\mathrm{mmHg}$ & $98 \pm 1$ & $97 \pm 1$ & $97 \pm 1$ & $99 \pm 2$ \\
\hline
\end{tabular}

n: number; BMI: body mass index; SBP: systolic blood pressure; DBP: diastolic blood pressure; $* P<0.05$ vs. II; $+P<0.05$ vs. ID.

Table 4.2. Characteristics of the study population with respect to AT1R A1166C polymorphism.

\begin{tabular}{|c|c|c|c|c|}
\hline & Total & AA & AC & CC \\
\hline Number, $n$ (\%) & $348(100)$ & $176(50.6)$ & $144(41.4)$ & $28(8.0)$ \\
\hline Males/females, $n$ & $125 / 223$ & $58 / 118$ & $54 / 90$ & $13 / 15$ \\
\hline Treated/untreated, $n$ & $204 / 144$ & $107 / 69$ & $78 / 66$ & $19 / 9$ \\
\hline Age, years & $53 \pm 1$ & $54 \pm 1$ & $52 \pm 1$ & $53 \pm 3$ \\
\hline $\mathrm{BMI}, \mathrm{kg} / \mathrm{m}^{2}$ & $27.7 \pm 0.3$ & $27.5 \pm 0.5$ & $27.8 \pm 0.5$ & $28.3 \pm 1.3$ \\
\hline Creatinine, $\mu \mathrm{mol} / \mathrm{L}$ & $86 \pm 1$ & $86 \pm 2$ & $84 \pm 2$ & $92 \pm 5$ \\
\hline Office SBP, $m m H g$ & $168 \pm 2$ & $167 \pm 2$ & $169 \pm 3$ & $173 \pm 5$ \\
\hline Office DBP, $m m H g$ & $98 \pm 1$ & $98 \pm 1$ & $97 \pm 1$ & $100 \pm 3$ \\
\hline
\end{tabular}

n: number; BMI: body mass index; SBP: systolic blood pressure; DBP: diastolic blood pressure.

\section{Daytime (9:00 AM-9:00 PM)}

For daytime pressures, significant relationships existed between genotype and SBP (Figure 4.1A), DBP (Figure 4.1B), and MBP. SBP was markedly higher in DD patients than in ID and II patients $(155 \pm 2$ vs. $149 \pm 2$ and $146 \pm 2 \mathrm{mmHg}$, respectively; $P<0.05)$. The same was true for DBP $(97 \pm 1$ vs. $92 \pm 1$ and $92 \pm 2 \mathrm{mmHg}$, respectively; $P<0.05)$ and $M B P(117 \pm 1$ vs. $112 \pm 1$ and $110 \pm 2 \mathrm{mmHg}$, respectively; $P<0.05)$. PP and HR did not differ between groups. Systolic, diastolic and mean blood pressure load (Figure 4.1C), as well as maximum systolic and mean load duration were significantly higher in DD patients compared to II patients. Systolic load events were significantly higher in DD patients in comparison to II patients. 


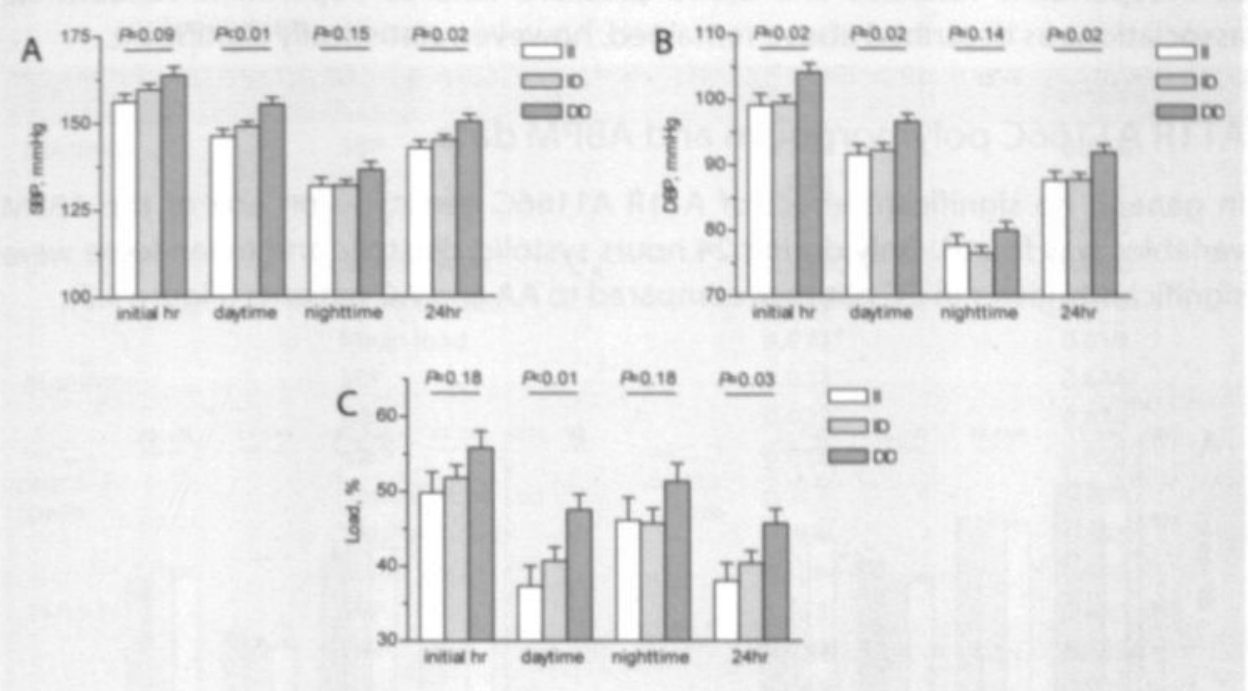

Figure 4.1 A. SBP during initial hour, daytime, nighttime, and 24 hours with respect to ACE VD polymorphism.

B. DBP during initial hour, daytime, nighttime, and 24 hours with respect to ACE VD polymorphism.

C. Blood pressure load during initial hour, daytime, nighttime, and 24 hours with respect to ACE I/D polymorphism.

Daytime (9:00 AM-9:00 PM, less initial hour), nighttime (1:00 AM-6:00 AM). P-values between groups as tested by One-Way ANOVA.

Nighttime (1:00 AM-6:00 AM)

During nighttime, only tendencies for higher systolic (Figure 4.1A), diastolic (Figure 4.1B), and mean blood pressures in DD individuals compared to II patients were found, but these were not significant. The same was found for systolic, diastolic, and mean blood pressure load (higher in DD individuals compared to II patients).

\section{4 hours}

As shown in Figure 4.1, twenty-four hour blood pressure and load were also significantly related to genotype, no matter whether systolic, diastolic or mean blood pressure (load) was taken as variable, with again higher values in DD patients compared to II patients. The systolic, diastolic and mean blood pressures in DD patients were also significantly higher compared to ID patients. Blood pressure variability over 24 hours and the degree of nocturnal dipping were not different between the genotype groups.

Since BMI appeared to be significantly higher in DD patients compared to II and ID patients (Table 4.2), we evaluated the relationship between blood pressure and $A C E ~ I / D$ genotype again in a multivariate regression model with genotype and BMI 
as independent variables and blood pressure data as dependent variable. All associations as described above remained, however, statistically significant.

\section{AT1R A1166C polymorphism and ABPM data}

In general no significant effect of AT1R A1166C genotype on any of the ABPM variables was found. Only during 24 hours systolic, diastolic and mean leese were significantly lower in CC patients compared to AA and AC patients (Figure 4.2).
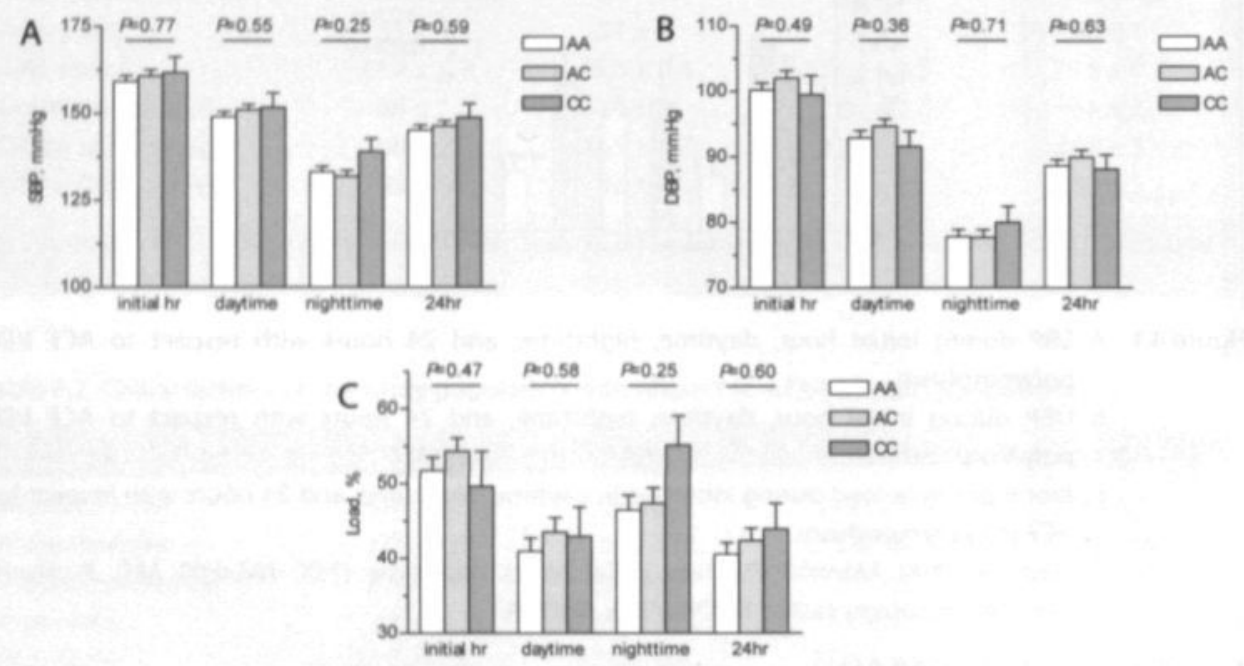

Figure 4.2 A. DBP during initial hour, daytime, nighttime, and 24 hours with respect to AT1R A1166C polymorphism.

B. SBP during initial hour, daytime, nighttime, and 24 hours with respect to AT1R A1166C polymorphism.

C. Blood pressure load during initial hour, daytime, nighttime, and 24 hours with respect to AT1R A1166C polymorphism.

Daytime (9:00 AM-9:00 PM, less initial hour), nighttime (1:00 AM-6:00 AM). P-values between groups as tested by One-Way ANOVA.

\section{Effect of treatment status and gender}

When ABPM data were analysed separately for those using or not using BPMD (BPMD+ and BPMD-, respectively), the associations as described above were apparent in both groups. When broken down by gender, there was a tendency for males to show more positive associations of the ACE I/D polymorphism with ABPM derivatives than females (Table 4.3). 
Table 4.3. P-values, according to gender, of associations of different ABPM derivatives with ACE VD polymorphism.

\begin{tabular}{|c|c|c|c|}
\hline & & Males & Females \\
\hline \multirow[t]{6}{*}{ Daytime } & SBP & $0.146 !$ & 0.010 \\
\hline & DBP & 0.042 & 0.123 \\
\hline & MBP & $0.053^{\prime}$ & 0.029 \\
\hline & Systolic load & $0.109 t$ & 0.020 \\
\hline & Diastolic load & $0.031^{*}$ & 0.240 \\
\hline & Mean load & $0.021^{*}$ & 0.059 \\
\hline \multirow[t]{6}{*}{ Nighttime } & SBP & $0.021^{\circ}$ & 0.644 \\
\hline & DBP & 0.023 & 0.818 \\
\hline & MBP & $0.016^{\circ}$ & 0.892 \\
\hline & Systolic load & 0.067 & 0.307 \\
\hline & Diastolic load & 0.066 & 0.867 \\
\hline & Mean load & 0.126 & 0.650 \\
\hline \multirow[t]{6}{*}{24 hours } & SBP & 0.093 & 0.050 \\
\hline & DBP & $0.033^{\circ}$ & 0.235 \\
\hline & MBP & $0.039^{\prime}$ & 0.102 \\
\hline & Systolic load & 0.138 & 0.058 \\
\hline & Diastolic load & $0.019^{*}$ & 0.471 \\
\hline & Mean load & 0.028 & 0.171 \\
\hline
\end{tabular}

\section{Inheritance model}

The positive associations of the ACE I/D polymorphism on blood pressure and blood pressure load were significant in all three models, but the most significant results were found in the recessive inheritance model.

\section{Discussion}

The present study shows that, when blood pressure is measured by means of ABPM, a clear, allele-dependent, association of the ACE I/D polymorphism with blood pressure can be found in patients with uncomplicated essential hypertension. The AT1R A1166C polymorphism, on the other hand, shows no consistent relationship with ABPM data.

The absence of an association between office blood pressure and the ACE I/D polymorphism is in agreement with the meta-analysis by Staessen et al. who concluded that the $D$ allele of the ACE I/D polymorphism is not associated with hypertension, but behaves as a marker of atherosclerotic cardiovascular complications and diabetic nephropathy. ${ }^{5}$ In almost all studies included in this 
meta-analysis office blood pressures were used instead of ABPM. Only a few studies addressed the association of the ACE I/D polymorphism with ambulatory measured blood pressure with both negative ${ }^{18-24}$ and positive findings. ${ }^{25-27}$ All these studies were relatively small and used 'standard' 24 hour ABPM parameters like daytime, nighttime and 24 hour blood pressure, rather than the more sophisticated ABPM derivatives like load, leese, variability, dipping, etc.

Recently, Matsubara et al. published data of a large Japanese general population cohort. ${ }^{28}$ In this cohort, 803 subjects were phenotyped for their blood pressures by means of the fully automatic device ABPM-630. The association of ambulatory blood pressure values with the ACE I/D polymorphism could not be confirmed. The conclusions of this study should be interpretated carefully. Firstly, the ABPM630 device, used in this study, is not validated by the British Hypertension Society. So, whether blood pressures values of this study are reliable is disputable. Secondly, although there was a Hardy-Weinberg equilibrium of this population, the allelic frequency of the D allele was low: $31.5 \%$ (compared to $55.2 \%$ in our study). Although this is a common finding in Japanese studies, this frequency is even lower than in other Japanese population studies. 29,30 This in combination with an unvalidated ambulatory blood pressure measuring device could theoretically harm the power (which is not mentioned) to find statistical differences. On the contrary, an even larger Japanese general population cohort dia' tinnd thie association of the ACE I/D polymorphism with hypertension, but only in men and not in females. ${ }^{29}$ Interestingly, gender-specific analyses of the study of Matsubara revealed a tendency of a higher prevalence of hypertension and a high odds ratio for the male DD genotype.

The maximal differences in blood pressure are to be expected between II and DD patients (largest genetic contrast). In the present study the differences in blood pressure between II and DD patients were 8-11 $\mathrm{mmHg}$ for SBP and 5-7 $\mathrm{mmHg}$ for DBP. Given this relatively small difference, earlier studies probably did not have enough power to find the association. Still, this small genotype effect may be of importance since, for instance, the Syst-Eur Trial recently showed that a $10 \mathrm{mmHg}$ higher 24 hour SBP is associated with an increased risk for various cardiovascular outcome measures ( $23 \%$ for total mortality; $47 \%$ for stroke) in older patients with systolic hypertension. ${ }^{31}$ So, such differences in blood pressure between genotypes as measured in the present study may have a major impact on cardiovascular morbidity and mortality.

Although we were able to show strong associations of ABPM derived blood pressure data with the ACE I/D polymorphism, it should be emphasized that these data were obtained in a rather selected cohort of hypertensive patients with, consequently, a narrow range of blood pressure at higher levels. Therefore, our results cannot simply be extrapolated to other patient groups or to normotensives. Further studies in subjects from a general population are needed to establish whether our findings also apply to the population at large. 
Several studies indicated that the association of the ACE gene locus with blood pressure is gender-dependent.12.13.32 Although in our group of untreated patients the subgroups of males $(n=58)$ and females $(n=86)$ were relatively small, our data confirm that there is a gender difference in the association of blood pressure with the ACE I/D polymorphism: in males the association was more prominent than in women. As for now, one can only speculate how the gender-specific impact of a polymorphism located on an autosomal chromosome can be explained. It could be that the ACE I/D polymorphism is in linkage disequilibrium with a functional mutation nearby which has a close interaction with a specific locus on chromosome $\mathrm{Y}$. The latter was suggested by Kreutz et al. to explain the sexdifferences in salt-loaded blood pressure levels among spontaneously hypertensive rats. ${ }^{33}$ Another explanation could be gender-specific regulation of the renin-angiotensin system (RAS), as proposed by Danser and Schunkert. ${ }^{34}$ For instance, in males renin and prorenin are $\approx 30 \%$ and $50 \%$ higher, respectively, than in women. ${ }^{35}$ As a corollary, males with the DD genotype (with higher circulating levels of ACE) may generate more Angl and Angll than females with the same genotype. It is also possible that androgens potentiate the contribution of the RAS to blood pressure. ${ }^{36}$ Finally, it may be that estrogens (during the premenopausal period) protect women against the negative effects of the ACE DD genotype, thus masking any gene-related blood pressure increase. If the latter is true, this protective effect should disappear after menopause. Although this study was not designed to address this issue, it was found that indeed in premenopausal women the relation between ACE I/D genotype and blood pressure (load) was absent, in contrary to postmenopausal women in which this association was prominent. Larger studies, especially designed to address this issue are needed to confirm this finding.

Our data further indicate that the effect of the ACE I/D polymorphism on blood pressure is more prominent for diastolic blood pressure than for systolic or pulse pressure. This is in agreement with the Framingham Heart Study data, where in a large cohort $(n=3095)$ associations with the ACE I/D polymorphism were even absent for systolic and pulse pressure. ${ }^{13}$

It is controversial whether the AT1R A1166C polymorphism is associated with blood pressure. After the first publication of Bonnardeaux et al. ${ }^{6}$ both positive ${ }^{37-41}$ and negative ${ }^{7,8,42,43}$ studies have been published. All of these addressed the relation with office blood pressure. Although we had expected to find higher blood pressure levels in patients with the CC genotype, we could not confirm this. Only during 24 hours systolic, diastolic and mean leese were significantly lower in CC patients compared to AA and AC patients. As these were the only associations with the AT1R A1166C polymorphism it should be concluded from this study that this polymorphism is not associated with ABPM derived blood pressure values. Earlier work of our group has shown that the $C$ allele of this polymorphism is associated with an increased sensitivity for Angll. ${ }^{16}$ Probably the effects of the 
AT1R A1166C polymorphism on cardiovascular function is (partly) blood pressure independent.

In summary, this study shows that ABPM is an useful tool to investigate the association of blood pressure with genetic polymorphisms. A positive association of the ACE I/D polymorphism with blood pressure and blood pressure load can be found. These associations are most prominent for DBP and for males. The AT1R A1166C polymorphism shows no allele-dependent association with blood pressure. Our data further illustrate once more that 'high-fidelity' phenotyping (ABPM instead of casual measurements) is an absolute prerequisite in studies on the genotype-phenotype relationships in hypertension. 


\section{Appendix}

Time weighted mean blood pressure:

ABPMs consist of samples taken over 24 hours. However they are not always taken at regular intervals (e.g. a patient might accidentally or deliberately take an extra reading or a reading might be missed). To calculate the relevant mean over a certain timeframe this must be taken into account. Each reading therefore represents a timeframe from halfway from its preceding reading to halfway to its succeeding reading. As for the first and last readings of each timeperiod this will give errors, the software program uses a frequency of one reading every 30 minutes $(0.556 \mathrm{kHz})$ to also calculate these timeframes. Missed readings are dealt with by allowing compensation for singletons. The maximum weight for one side (to preceding or succeeding reading) is therefore the period.

Load:

Area of the curve above an upper limit of normality (daytime: 135/90, nighttime: 120/70) expressed as a percentage of the area of the curve above an average of normality (daytime: 122/78, nighttime: 105/60) where values below the upper limit are regarded as being at that limit.

Leese:

Area of the curve below a lower limit of normality (daytime: 110/66, nighttime: 90/50) expressed as a percentage of the area of the curve below an average of normality (daytime: 122/78, nighttime: 105/60) where values above the lower limit are regarded as being at that limit.

Number of load events:

Distinct occasions when curve goes above normal.

Number of leese events:

Distinct occasions when curve goes below normal.

Maximum load duration:

Longest period when curve is continuously above normal.

Maximum leese duration:

Longest period when curve is continuously below normal.

Percentage dipping:

(daytime value less nighttime value)/(daytime value)·100. 


\section{References}

1. Lander ES, Schork NJ. Genetic dissection of complex traits. Science 1994;265:2037-48.

2. Borhani NO, Feinleib M, Garrison RJ, Christian JC, Rosenman RH. Genetic variance in blood pressure. Acta Genet Med Gemellol (Roma) 1976;25:137-44.

3. Rice T, Vogler GP, Perusse L, Bouchard C, Rao DC. Cardiovascular risk factors in a French Canadian population: resolution of genetic and familial environmental effects on blood pressure using twins, adoptees, and extensive information on environmental correlates. Genet Epidemiol 1989;6:571-88.

4. Smith TW, Turner CW, Ford MH, Hunt SC, Barlow GK, Stults BM, Williams RR. Blood pressure reactivity in adult male twins. Health Psychol 1987;6:209-20.

5. Woolfson RG, de Wardener HE. Primary renal abnormalities in hereditary hypertension. Kidney Int 1996;50:717-31.

6. Guidi E, Menghetti D, Milani S, Montagnino G, Palazzi P, Bianchi G. Hypertension may be transplanted with the kidney in humans: a long-term historical prospective follow-up of recipients grafted with kidneys coming from donors with or without hypertension in their families. J Am Soc Nephrol 1996;7:1131-8.

7. Tiret L, Rigat B, Visvikis S, Breda C, Corvol P, Cambien F, Soubrier F. Evidence, from combined segregation and linkage analysis, that a variant of the angiotensin I-converting enzyme (ACE) gene controls plasma ACE levels. Am J Hum Genet 1992;51:197-205.

8. Cambien F. The angiotensin-converting enzyme (ACE) genetic polymorphism: its relationship with plasma ACE level and myocardial infarction. Clin Genet 1994;46:94-101.

9. Samani NJ, Thompson JR, O'Toole L, Channer K. Woods KL. A meta-analysis of the association of the deletion allele of the angiotensin-converting enzyme gene with myocardial infarction. Circulation 1996:94:708-12.

10. Agerholm-Larsen B, Nordestgaard BG, Tybjaerg-Hansen A. ACE gene polymorphism in cardiovascular disease: meta-analyses of small and large studies in whites. Arterioscler Thromb Vasc Biol 2000;20:484-92.

11. Keavney B, McKenzie C, Parish S, Palmer A, Clark S, Youngman L, Delepine M, Lathrop M, Peto R, Collins R. Large-scale test of hypothesised associations between the angiotensin-convertingenzyme insertion/deletion polymorphism and myocardial infarction in about 5000 cases and 6000 controls. International Studies of Infarct Survival (ISIS) Collaborators. Lancet 2000;355:434-42.

12. Staessen JA, Wang JG, Ginocchio G, Petrov V, Saavedra AP, Soubrier F, Vlietinck R, Fagard R. The deletion/insertion polymorphism of the angiotensin converting enzyme gene and cardiovascular-renal risk. J Hypertens 1997;15:1579-92.

13. Tiret L, Blanc $H$, Ruidavets JB, Arveiler D, Luc G, Jeunemaitre X, Tichet J, Mallet C, Poirier O, Plouin PF, Cambien F. Gene polymorphisms of the renin-angiotensin system in relation to hypertension and parental history of myocardial infarction and stroke: the PEGASE study. Projet d'Etude des Genes de I'Hypertension Arterielle Severe a moderee Essentielle. J Hypertens 1998;16:37-44.

14. Benetos A, Topouchian J, Ricard S, Gautier S, Bonnardeaux A, Asmar R, Poirier O, Soubrier F, Safar $\mathrm{M}$. Cambien F. Influence of angiotensin II type 1 receptor polymorphism on aortic stiffness in never-treated hypertensive patients. Hypertension 1995;26:44-7.

15. Benetos A, Gautier S, Ricard S, Topouchian J, Asmar R, Poirier O, Larosa E, Guize L, Safar M, Soubrier F, Cambien F. Influence of angiotensin-converting enzyme and angiotensin II type 1 receptor gene polymorphisms on aortic stiffness in normotensive and hypertensive patients. Circulation 1996:94:698-703.

16. Bonnardeaux A, Davies E, Jeunemaitre X, Fery I, Charru A, Clauser E, Tiret L, Cambien F, Corvol P, Soubrier $F$. Angiotensin II type 1 receptor gene polymorphisms in human essential hypertension. Hypertension 1994:24:63-9.

17. Wang WY, Zee RY, Morris BJ. Association of angiotensin II type 1 receptor gene polymorphism with essential hypertension. Clin Genet 1997;51:31-4. 
18. Spiering W, Kroon AA, Fuss-Lejeune MM, Daemen MU, de Leeuw PW. Angiotensin II sensitivity is associated with the angiotensin II type 1 receptor $A(1166) C$ polymorphism in essential hypertensives on a high sodium diet. Hypertension 2000;36:411-6.

19. van Geel PP, Pinto YM, Voors AA, Buikema $H$, Oosterga M, Crijns HJ, van Gilst WH. Angiotensin II type 1 receptor $A 1166 C$ gene polymorphism is associated with an increased response to angiotensin II in human arteries. Hypertension 2000;35:717-21.

20. Tiret L, Bonnardeaux A, Poirier O, Ricard S, Marques-Vidal P, Evans A, Arveiler D, Luc G, Kee F, Ducimetiere P, et al. Synergistic effects of angiotensin-converting enzyme and angiotensin- II type 1 receptor gene polymorphisms on risk of myocardial infarction. Lancet 1994:344:910-3.

21. Alvarez R, Reguero JR, Batalla A, Iglesias-Cubero G, Cortina A, Alvarez V, Coto E. Angiotensinconverting enzyme and angiotensin II receptor 1 polymorphisms: association with early coronary disease. Cardiovasc Res 1998;40:375-9.

22. Fatini C, Abbate R, Pepe G, Battaglini B, Gensini F, Ruggiano G, Gensini GF, Guazzelli R. Searching for a better assessment of the individual coronary risk profile. The role of angiotensin-converting enzyme, angiotensin II type 1 receptor and angiotensinogen gene polymorphisms. Eur Heart J 2000;21:633-8.

23. Zee RY, Lou YK, Griffiths LR, Morris BJ. Association of a polymorphism of the angiotensin Iconverting enzyme gene with essential hypertension. Biochem Biophys Res Commun 1992;184: 9-15.

24. Castellano M, Muiesan ML, Beschi M, Rizzoni D, Cinelli A, Salvetti M, Pasini G, Porteri E, Bettoni G. Zulli R, Agabiti-Rosei E. Angiotensin II type 1 receptor A/C1166 polymorphism. Relationships with blood pressure and cardiovascular structure. Hypertension 1996;28:1076-80.

25. Schmidt S, Beige J, Walla-Friedel M, Michel MC, Sharma AM, Ritz E. A polymorphism in the gene for the angiotensin II type 1 receptor is not associated with hypertension. J Hypertens 1997;15:1385-8.

26. Gardemann A, Nguyen QD, Humme J, Stricker J, Katz N, Tillmanns H, Hehrlein FW, Rau M, Haberbosch W. Angiotensin II type 1 receptor A1166C gene polymorphism. Absence of an association with the risk of coronary artery disease and myocardial infarction and of a synergistic effect with angiotensin-converting enzyme gene polymorphism on the risk of these diseases. Eur Heart J 1998;19:1657-65.

27. Stefansson B, Ricksten A, Rymo L, Aurell M, Herlitz H. Angiotensin-converting enzyme gene I/D polymorphism in malignant hypertension. Blood Press 2000;9:104-9.

28. Steeds RP, Wardle A, Smith PD, Martin D, Channer KS, Samani NJ. Analysis of the postulated interaction between the angiotensin II sub-type 1 receptor gene A1166C polymorphism and the insertion/deletion polymorphism of the angiotensin converting enzyme gene on risk of myocardial infarction. Atherosclerosis 2001;154:123-8.

29. Metsemakers JF, Hoppener P, Knottnerus JA, Kocken RJ, Limonard CB. Computerized health information in The Netherlands: a registration network of family practices. $\mathrm{Br} J \mathrm{Gen}$ Pract 1992;42:102-6.

30. Walma EP, Grundmeijer HG, Thomas S, Prins A, van den Hoogen JP, van der Laan JR. NHGstandaard hypertensie. Huisarts Wet 1997;40:598-617.

31. Cockcroft DW, Gault MH. Prediction of creatinine clearance from serum creatinine. Nephron 1976;16:31-41.

32. Rigat B, Hubert C, Corvol P, Soubrier F. PCR detection of the insertion/deletion polymorphism of the human angiotensin converting enzyme gene (DCP1) (dipeptidyl carboxypeptidase 1). Nucleic Acids Res 1992;20:1433.

33. Shanmugam V, Sell KW, Saha BK. Mistyping ACE heterozygotes. PCR Methods Appl 1993;3:120-1.

34. Falconer DS. Introduction to quantitative genetics. 3rd ed. Essex: Longman; 1989.

35. Hosmer DW, Lemeshow S. Interpretation of the fitted logistic regression model. In: Applied logistic regression. 2nd ed. New York: Wiley-Interscience; 2000:47-90.

36. O'Donnell CJ, Lindpaintner K, Larson MG, Rao VS, Ordovas JM, Schaefer EJ, Myers RH, Levy D. Evidence for association and genetic linkage of the angiotensin-converting enzyme locus with hypertension and blood pressure in men but not women in the Framingham Heart Study. Circulation 1998;97:1766-72. 
37. Uemura K, Nakura J, Kohara K, Miki T. Association of ACE I/D polymorphism with cardiovascular risk factors. Hum Genet 2000;107:239-42.

38. Zaman MM, Yoshiike N, Date C, Yokoyama T, Matsumura Y, Ikemoto S, Tanaka H. Angiotensin converting enzyme genetic polymorphism is not associated with hypertension in a crosssectional sample of a Japanese population: the Shibata Study. J Hypertens 2001;19:47-53.

39. Jeunemaitre X, Lifton RP, Hunt SC, Williams RR, Lalouel JM. Absence of linkage between the angiotensin converting enzyme locus and human essential hypertension. Nat Genet 1992;1:72-5.

40. Berge KE, Berg K. No effect of insertion/deletion polymorphism at the ACE locus on normal blood pressure level or variability. Clin Genet 1994;45:169-74.

41. Kiema TR, Kauma H, Rantala AO, Lilja M, Reunanen A, Kesaniemi YA, Savolainen MJ. Variation at the angiotensin-converting enzyme gene and angiotensinogen gene loci in relation to blood pressure. Hypertension 1996;28:1070-5.

42. Rigat B, Hubert C, Alhenc-Gelas F, Cambien F, Corvol P, Soubrier F. An insertion/deletion polymorphism in the angiotensin l-converting enzyme gene accounting for half the variance of serum enzyme levels. J Clin Invest 1990;86:1343-6.

43. Hingorani AD, Jia $H$, Stevens PA, Hopper R, Dickerson JE, Brown MJ. Renin-angiotensin system gene polymorphisms influence blood pressure and the response to angiotensin converting enzyme inhibition. J Hypertens 1995;13:1602-9.

44. Rice GI, Foy CA, Grant PJ. Angiotensin converting enzyme and angiotensin II type 1-receptor gene polymorphisms and risk of ischaemic heart disease. Cardiovasc Res 1999;41:746-53.

45. Staessen JA, Wang JG, Brand E, Barlassina C, Birkenhager WH, Herrmann SM, Fagard R, Tizzoni L, Bianchi G. Effects of three candidate genes on prevalence and incidence of hypertension in a Caucasian population. J Hypertens 2001;19:1349-58. 


\section{Chapter 5}

Slow angiotensin-converting enzymerelated conversion of angiotensin I in plasma of hypertensive patients: relationship with the angiotensinconverting enzyme insertion/deletion polymorphism

Wilko Spiering, Paul M. Schiffers, Abraham A. Kroon, Peter W. de Leeuw Submitted for publication 


\section{Abstract}

\section{Background}

It is still unknown whether D allele carriers of the angiotensin-converting enzyme (ACE) insertion/deletion (I/D) polymorphism exhibit enhanced conversion of angiotensin I (Angl). Therefore, we conducted an in vitro study in which the plasmatic conversion of Angl over time in relation to the $A C E$ I/D polymorphism was investigated. Both the immediate and the long-term conversion were studied.

\section{Methods}

In $14 \mathrm{II}, 16 \mathrm{ID}$, and $16 \mathrm{DD}$ hypertensives, changes in Angl and Angll concentrations were measured at $0,60,120$ and $180 \mathrm{~min}$ after blood withdrawal. Similar experiments were performed after adding either excess Angl or enalaprilate to the plasma at baseline.

\section{Results}

Over a period of three hours, II and ID subjects showed a significant decline in Angl levels compared to baseline (at maximum $16 \%$ and $19 \%$, respectively; $P<0.05$ ), whereas DD subjects showed no significant change. After adding exogenous Angl, all genotype groups immediately metabolized more than $90 \%$ of the peptide, but continued to show significant decreases of about $50 \%$ in Angl as compared to baseline over the next few hours. No changes in Angl were observed in enalaprilate-treated plasma. Angll levels decreased in DD subjects both with (at maximum -18\%; $P<0.05$ ) and without (at maximum -37\%; $P<0.05$ ) exogenous Angl but not in the others. No changes in any group were seen in the enalaprilate experiments.

\section{Conclusion}

Our data show that following the immediate conversion of Angl, a secondary phase of slow conversion is demonstrable. While the initial phase does not differ between the three genotype groups, the slow conversion of Angl does with the lowest conversion occurring in $\mathrm{DD}$ patients. The difference can be overcome at higher prevailing concentrations of Angl. 


\section{Introduction}

Since individuals who are homozygous for the deletion variant (DD) of the angiotensin-converting enzyme (ACE) gene express about $50 \%$ higher levels of the enzyme than II subjects, ${ }^{1}$ it is tempting to hypothesize that they also have increased conversion of angiotensin I (Angl). Indirect support for this hypothesis comes from epidemiological studies which show that a number of hypertensive and atherosclerotic complications occur more frequently in DD patients. ${ }^{2-13}$ This would at least be compatible with enhanced formation of Angll, a peptide with known deleterious effects on the cardiovascular system. However, studies which compared the vasoconstrictor responses to Angl in subjects with the different genotypes have produced conflicting results. While some investigators reported enhanced pressor responses to Angl in DD subjects, 14,15 others failed to confirm this. ${ }^{16,17}$ The fact that $D$ allele carriers do not exhibit a compensatory suppression of circulating renin ${ }^{18}$ even argues against increased generation of Angll from Angl. Since the results of in vivo studies may be confounded by many variables that cannot be adequately controlled, it seems preferable in this respect to assess potential differences in Angl conversion between individuals with different genotypes under in vitro conditions. Of note, some investigators have reported that ACE itself is functionally similar in the three genotypes, 19,20 but they all used artifical substrates. Because kinetic parameters for ACE may be somewhat different with Angl as substrate, there is a case for studying the spontaneous plasmatic conversion of Angl into Angll. However, given the low concentrations of angiotensins in plasma which are well below the $K_{M}$ value for the enzymatic reaction between $A C E$ and Angl, the rate of conversion in normal plasma must be independent of Angl levels. This, together with the fact that metabolization of Angl into Angll is a fast process taking place within seconds to minutes, would make it unlikely to see major differences in plasmatic Angl conversion in relation to genotype. Consequently, if there are differences in the degree of Angl conversion between individuals, one would have to invoke another mechanism of conversion, possibly occurring at a slower pace. This led us to hypothesize that there might be a secondary, slower, conversion phase which either or not is related to ACE itself and which could lead to differences between patient groups. To put this to the test, we followed changes in Angl concentrations over a prolonged period of time in plasma which was maintained in a waterbath at a constant temperature of $37^{\circ} \mathrm{C}$ and to which a renin-inhibitor had been added. Plasma samples were either untreated or spiked with an excess of exogenous Angl. Although changes in the concentration of Angl were taken as the primary outcome variable, we also measured Angll concentrations at the various time points. 


\section{Methods}

\section{Patients}

Patients were randomly selected from a genetic database of hypertensive patients genotyped for the ACE insertion/deletion (I/D) polymorphism. All selected patients (14 II, 16 ID, 16 DD) gave written informed consent (both genotyping and blood withdrawal) to participate in the study. Antihypertensive medication had been stopped 3 weeks prior to blood withdrawal. Patients refrained from nicotine, alcohol, caffeine and caffeine-like substances from 8:00 PM the evening before blood withdrawal. The study was approved by the Medical Ethics Committee of the University Hospital Maastricht.

\section{Genetic analysis}

DNA was extracted from whole blood using the QIAamp Blood Kit (Qiagen Inc., Valencia, CA, USA). The ACE I/D polymorphism was detected using the technique described by Rigat et al.21 A second PCR was performed to avoid misidentification of ID as DD. ${ }^{22}$

\section{Biochemical measurements}

Venous blood $(40 \mathrm{~mL})$ was collected into polystyrene tubes containing $2 \mathrm{~mL}$ of sampling buffer (composition: $7 \% \mathrm{w} / \mathrm{v}$ trisodium citrate, $35 \mathrm{mmol} / \mathrm{L}$ ophenanthroline (Sigma P9375), 0.04 mmol/L renin-inhibitor (Sigma C9415)). After withdrawal, blood was rapidly centrifuged at $37^{\circ} \mathrm{C}$ at $3000 \mathrm{rpm}$ for $15 \mathrm{~min}$. The supernatant was then distributed in 4 parts $(\mathrm{t}=0, \mathrm{t}=60, \mathrm{t}=120$ and $\mathrm{t}=180 \mathrm{~min})$ and incubated at $37^{\circ} \mathrm{C}$. The conversion from Angl to Angll was stopped in different tubes at baseline $(t=0)$ and at 60,120 and 180 min by adding enalaprilate $(0.5 \mathrm{~mL}$, $0.25 \mathrm{mmol} / \mathrm{L}$ ). Subsequently, plasma was quickly frozen in liquid nitrogen and stored until assay. A second series had the same work up, but contained $150 \mathrm{pg}$ Angl per $\mathrm{mL}$ blood $(=115.7 \mathrm{pmol} / \mathrm{L})$ that was added at baseline. Angl and Angll were determined by standard radioimmunoassay (Peninsula Laboratories Europe, St. Helens, UK) following C-18 Sep-Pak (Waters-Millipore) extraction of the peptides. Intra- and intercoefficients of variation of all assays were $<10 \%$. Crossreactivity of antibodies for Angl and Angll assays were $<0.2 \%$. All samples from the same individual were assayed in a single run. To assess whether changes in Angl were dependent on $A C E$, a control experiment was performed as follows. Venous blood samples from $8 \mathrm{II}, 10 \mathrm{ID}$, and $11 \mathrm{DD}$ subjects were collected in sampling buffers to which enalaprilate $(0.5 \mathrm{~mL}, 0.25 \mathrm{mmol} / \mathrm{L})$ had been added. After isolating plasma, Angl and Angll were again measured at 0, 120, and $180 \mathrm{~min}$. 


\section{Statistical analysis}

Data are shown as medians and interquartile ranges (IQR). Both absolute and relative changes of Angl conversion are shown. Relative changes are expressed as the percentage change compared to baseline. Because of small samples sizes $(n<20)$ non-parametric tests were used. The Chi-Square test was applied to compare categorical data (e.g. gender) between genotype groups. Wilcoxon Signed Rank test was used for differences within groups. To compare data between groups (II, ID, and DD) a two step approach was taken. First, overall differences between groups were evaluated by means of Kruskall-Wallis analysis of variance. When these analyses revealed a significant effect of genotype, data were further tested by pairwise comparisons using the Mann-Whitney $U$ test. A P. value of less than 0.05 was considered to be statistically significant. Statistical analyses were performed using SPSS 11.0 for Windows (SPSS Inc., Chicago, IL, USA).

\section{Results}

\section{Subjects}

A total of 46 subjects (17 males and 29 females) were selected: 14 II, 16 ID, and 16 DD. The overall median age was $53($ IQR 49,63$)$ years. There were no significant differences in gender and age between the groups.

\section{Conversion of endogenous Angl}

At baseline, plasma Angl levels were comparable between the genotype groups (II: $7.28 \mathrm{pmol} / \mathrm{L}$; ID: $9.78 \mathrm{pmol} / \mathrm{L} ; \mathrm{DD}: 8.66 \mathrm{pmol} / \mathrm{L} ; P=0.66)$, and so were plasma Angll levels (II: $7.27 \mathrm{pmol} / \mathrm{L}$; ID: $6.80 \mathrm{pmol} / \mathrm{L}$; DD: $6.17 \mathrm{pmol} / \mathrm{L} ; P=0.85$ ). However, II and ID subjects showed a significant decline in Angl levels at 120 and 180 min compared to baseline $(P<0.05)$, whereas in DD subjects only small changes were found which were not statistically significant (Figure 5.1).

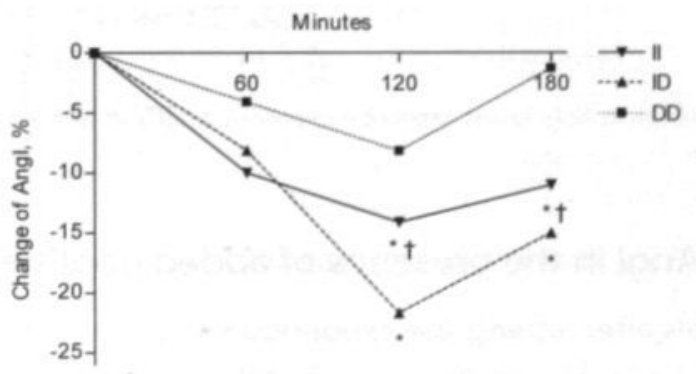

Figure 5.1. Relative change in Angl levels without exogenous Angl. ${ }^{*} P<0.05$ vs. baseline; ${ }^{+} P<0.05$ vs. DD. 
At 120 and 180 min Angl levels were significantly lower in II subjects (5.97 and 6.79 $\mathrm{pmol} / \mathrm{L}$, respectively) than in DD subjects (8.51 and $9.27 \mathrm{pmol} / \mathrm{L}$, respectively; $P<0.05$ vs. II). No significant differences for Angl levels were found between II and ID. The maximum decreases in Angl concentrations in II and ID subjects were reached at $120 \mathrm{~min}$ (16 and 19\%, respectively; Figure 5.1). DD subjects showed a significant decrease in Angll at 60 (-19.7\%), $120(-17.4 \%)$ and $180(-37.4 \%) \mathrm{min}$ compared to baseline (all: $P<0.05$; Figure 5.2). In II and ID subjects, on the other hand, no significant changes in Angll occurred (Figure 5.2). The control experiment, in which the effect of inhibition of converting enzyme was tested, showed no significant changes in either Angl or Angll levels during the $180 \mathrm{~min}$ of the experiment in any of the genotype groups (Figures 5.3 and 5.4), suggesting that under the conditions of study the decreases in Angl concentrations were related to conversion by $A C E$.

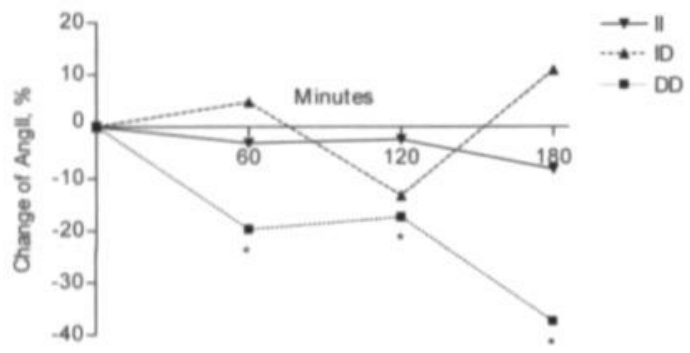

Figure 5.2. Relative change in Angll levels without exogenous Angl. ${ }^{*} P<0.05$ vs. baseline.

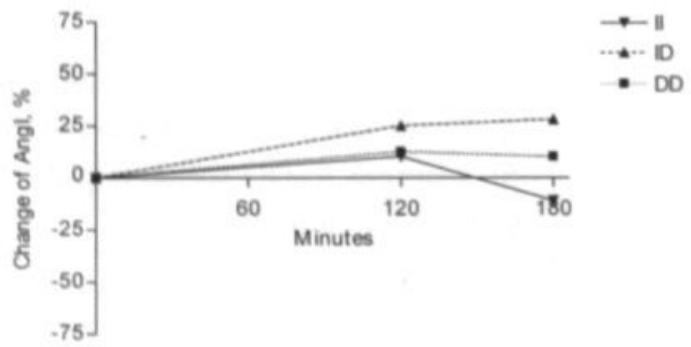

Figure 5.3. Relative change in Angl levels without exogenous Angl and with enalaprilate.

\section{Conversion of Angl in the presence of added peptide}

Baseline Angl levels after adding the exogenous Angl were about $15 \mathrm{pmol} / \mathrm{L}$ in all genotype groups. Since $150 \mathrm{pg} / \mathrm{mL}(=115.6 \mathrm{pmol} / \mathrm{L})$ had been added to the tubes, all groups had immediately converted more than $87 \%$ of the excess Angl within the first few seconds during which the plasma was processed. All genotype 
groups showed a significant decrease of about $50 \%$ in Angl at 60, 120 and $180 \mathrm{~min}$ as compared to baseline (Figure 5.5). This decrease was not significantly different between the groups. DD subjects showed a significant decrease in Angll at 180 $\min (-18.2 \%)$ compared to baseline $(P<0.05$, Figure 5.6$)$. Angll did not significantly change in II and ID subjects.

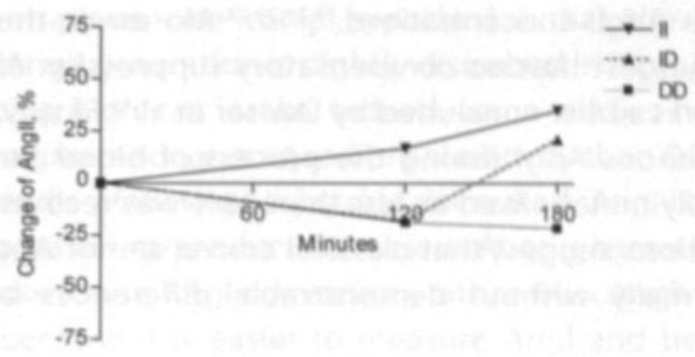

Figure 5.4. Relative change in Angll levels without exogenous Angl and with enalaprilate.

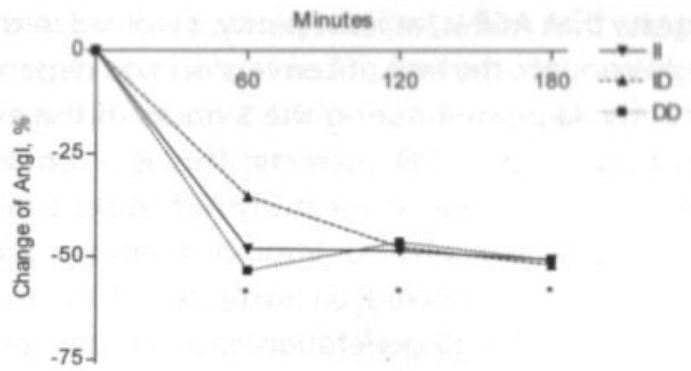

Figure 5.5. Relative change in Angl levels with exogenous Angl. " $P<0.05$ vs. baseline.

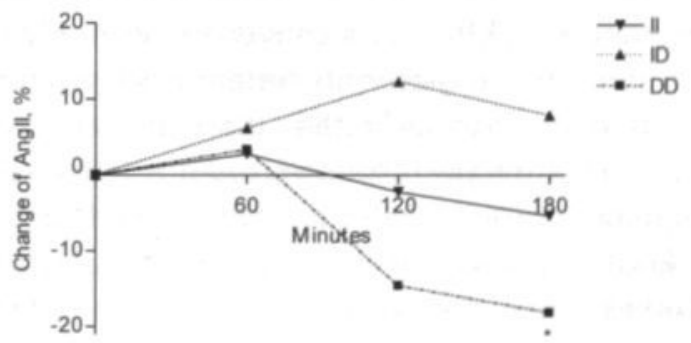

Figure 5.6. Relative change in Angll levels with exogenous Angl. ${ }^{*} P<0.05$ vs. baseline. 


\section{Discussion}

This study investigated spontaneous changes in Angl concentrations in plasma in relation to the ACE I/D polymorphism. Baseline plasma levels of Angl and Angll were comparable in the three genotype groups which is in line with earlier studies demonstrating that the higher ACE levels in D allele carriers do not lead to higher circulating plasma Angll concentrations. ${ }^{14-16,23.24}$ Moreover, the comparable Angl levels indirectly suggest that no compensatory suppression of renin occurs in D allele carriers, as was earlier concluded by Danser et al. ${ }^{18}$ Finally, when plasma was spiked with exogenous Angl during the process of blood sampling, the excess peptide was rapidly metabolized as less than $13 \%$ was recovered after one hour. All these observations suggest that classical conversion of Angl as it is known to us, occurred normally without demonstrable differences between genotype groups.

The results of our experiments further show that over a prolonged period of time additional changes in peptide levels occur. Although such changes could, in theory, be non-specific they could be prevented by adding enalaprilate to the test medium. This suggests that ACE is, at least partly, involved in the slow conversion of Angl. Interestingly enough, the rate of conversion was dependent on genotype. While Angl significantly decreased during the 3 hours of the experiment in II and ID carriers, it hardly changed in DD subjects. This is a remarkable finding and indicates that under the conditions of our study ACE in DD subjects, if anything, is working at a slower rate. At first sight, our findings seem to be in contrast with the results of two studies which showed an increased Angl-II conversion. ${ }^{14.25}$ For instance, Ueda et al. studied Angll generation and systemic pressor responses in normotensive men. They provided evidence for enhanced Angl-II conversion in DD subjects as compared to subjects with the II genotype. However, statistical significance for the difference between II and DD subjects was obtained only at the highest Angl dose $(20 \mathrm{ng} / \mathrm{kg} / \mathrm{min})$ that was tested, leading the authors to conclude that $\mathrm{D}$ allele-related effects on conversion will only be observed under conditions in which the renin-angiotensin system is stimulated. ${ }^{14}$ Another group of investigators focused on vascular, rather than circulating or systemic AngI-II conversion, by studying contractile responses to Angl and Angll in preparations of human internal mammary arteries in vitro. Combining ID and DD patients, they found increased Angl-II conversion in this group compared to II patients. However, other studies, using the systemic, ${ }^{16}$ forearm ${ }^{15,24}$ and isolated arteries ${ }^{17}$ model failed to find increased Angl-II conversion. Interestingly, when we added an extra amount of Angl to obtain high normal levels $(\approx 15 \mathrm{pmol} / \mathrm{L})$, plasma samples of DD subjects showed the same decline in Angl as II and ID subjects. A possible explanation for this phenomenon could be that plasma of DD subjects contains a factor which blocks the slow conversion phase of Angl at relatively low concentrations of this peptide but loses its power when Angl rise. This could be 
the case when the unknown factor is a weak competitive inhibitor of the binding of Angl to ACE.

The plasma levels of Angl that we obtained after adding exogenous Angl were well within the range that one could expect during sodium restriction or after diuretic treatment. Conversely, baseline levels were as one would expect on a liberal salt intake. Since conversion of Angl in DD subjects seems to be slower at low plasma concentrations, one could hypothesize that the balance between volume status and Angll generation is slightly disturbed in II subjects as compared to DD subjects during high salt intake. Indeed, some studies have shown that II individuals display a greater degree of sodium sensitivity than DD subjects. ${ }^{26,27}$ In enzyme kinetic studies, following substrate decrease (=Angl conversion) has the same meaning as measuring product increase (=Angll generation). In this study, we deliberately chose to use Angl conversion, rather than Angll generation as the primary outcome because it is easier to measure Angl and because we cannot exclude generation of other angiotensins, which would escape our assay system. However, for the sake of completeness we also followed changes in Angll concentrations and, surprisingly, found these to remain unchanged in II and ID subjects but to decrease in DD patients, at least when ACE was not blocked. In the enalaprilate experiments no changes in Angll whatsoever were apparent in any of the groups. This suggests that any new formation of Angll is immediately followed by removal of the octapeptide. While this latter process may be slow in persons carrying the II or ID genotype, it apparently occurs much more quickly in DD individuals. Our data further indicate that this process is dependent upon normally functioning $A C E$ and raises the question whether $A C E$ itself is not responsible for enhanced degradation of Angll. Further experiments are needed, however, to explore this issue in greater detail.

As any in vitro study, the present one also has its limitations. We only focussed on soluble ACE activity and, hence, the role of membrane-bound ACE in Angl-II conversion remains unclear. In vivo, membrane-bound ACE is probably more important for Angl-II conversion than soluble ACE. Accordingly, the rate of the slow Angl conversion may be different at the tissue level.

In conclusion, this study shows that the DD genotype of the ACE I/D polymorphism, at least at low plasma concentrations of Angl, is associated with a slower secondary conversion of this peptide. This could mean that the increased plasma ACE levels that are seen in D allele carriers serve as a compensatory mechanism to allow for sufficient ongoing conversion of Angl into Angll. 


\section{References}

1. Rigat B, Hubert C, Alhenc-Gelas F, Cambien F, Corvol P, Soubrier F. An insertion/deletion polymorphism in the angiotensin I-converting enzyme gene accounting for half the variance of serum enzyme levels. J Clin Invest 1990;86:1343-6.

2. Cambien F, Poirier O, Lecerf L, Evans A, Cambou JP, Arveiler D, Luc G, Bard JM, Bara L, Ricard S, Tiret L, Amouyel P, Alhenc-Gelas F, Soubrier F. Deletion polymorphism in the gene for angiotensin-converting enzyme is a potent risk factor for myocardial infarction. Nature 1992;359:641-4.

3. Bengtsson K, Orho-Melander M, Lindblad U, Melander O, Bog-Hansen E, Ranstam J, Rastam L, Groop L. Polymorphism in the angiotensin converting enzyme but not in the angiotensinogen gene is associated with hypertension and type 2 diabetes: the Skaraborg Hypertension and diabetes project. J Hypertens 1999;17:1569-75.

4. Gardemann A, Fink M, Stricker J, Nguyen QD, Humme J, Katz N, Tillmanns H, Hehrlein FW, Rau M, Haberbosch W. ACE I/D gene polymorphism: presence of the ACE D allele increases the risk of coronary artery disease in younger individuals. Atherosclerosis 1998;139:153-9.

5. Lindpaintner K, Pfeffer MA, Kreutz R, Stampfer MJ, Grodstein F, LaMotte F, Buring J, Hennekens $\mathrm{CH}$. A prospective evaluation of an angiotensin-converting-enzyme gene polymorphism and the risk of ischemic heart disease. N Engl J Med 1995;332:706-11.

6. Ledru F, Blanchard D, Battaglia S, Jeunemaitre X, Courbon D, Guize L, Guermonprez JL, Ducimetiere $\mathrm{P}$, Diebold $\mathrm{B}$. Relation between severity of coronary artery disease, left ventricular function and myocardial infarction, and influence of the ACE I/D gene polymorphism. Am J Cardiol 1998;82:160-5.

7. Iwai N, Ohmichi N, Nakamura Y, Kinoshita M. DD genotype of the angiotensin-converting enzyme gene is a risk factor for left ventricular hypertrophy. Circulation 1994;90:2622-8.

8. Castellano M, Muiesan ML, Rizzoni D, Beschi M, Pasini G, Cinelli A, Salvetti M, Porteri E, Bettoni G, Kreutz R, et al. Angiotensin-converting enzyme I/D polymorphism and arterial wall thickness in a general population. The Vobarno Study. Circulation 1995;91:2721-4.

9. Amouyel P, Richard F, Cottel D, Amant C, Codron V, Helbecque N. The deletion allele of the angiotensin I converting enzyme gene as a genetic susceptibility factor for cognitive impairment. Neurosci Lett 1996;217:203-5.

10. Marre M, Jeunemaitre X, Gallois Y, Rodier M, Chatellier G, Sert C, Dusselier L, Kahal Z, Chaillous L. Halimi S, Muller A, Sackmann H, Bauduceau B, Bled F, Passa P, Alhenc-Gelas F. Contribution of genetic polymorphism in the renin-angiotensin system to the development of renal complications in insulin-dependent diabetes: Genetique de la Nephropathie Diabetique (GENEDIAB) study group. J Clin Invest 1997;99:1585-95.

11. Kim DK, Kim JW, Kim S, Gwon HC, Ryu JC, Huh JE, Choo JA, Choi Y, Rhee CH, Lee WR. Polymorphism of angiotensin converting enzyme gene is associated with circulating levels of plasminogen activator inhibitor-1. Arterioscler Thromb Vasc Biol 1997;17:3242-7.

12. Montgomery H, Clarkson P, Barnard M, Bell J, Brynes A, Dollery C, Hajnal J, Hemingway $\mathrm{H}$, Mercer D, Jarman P, Marshall R, Prasad K, Rayson M, Saeed N, Talmud P, Thomas L, Jubb M, World M, Humphries S. Angiotensin-converting-enzyme gene insertion/deletion polymorphism and response to physical training. Lancet 1999;353:541-5.

13. Gumprecht J, Zychma MJ, Grzeszczak W, Zukowska-Szczechowska E. Angiotensin 1-converting enzyme gene insertion/deletion and angiotensinogen M235T polymorphisms: risk of chronic renal failure. End-Stage Renal Disease Study Group. Kidney Int 2000;58:513-9.

14. Ueda S, Elliott HL, Morton JJ, Connell JM. Enhanced pressor response to angiotensin I in normotensive men with the deletion genotype (DD) for angiotensin-converting enzyme. Hypertension 1995;25:1266-9.

15. van Dijk MA, Kroon I, Kamper AM, Boomsma F, Danser AH, Chang PC. The angiotensin-converting enzyme gene polymorphism and responses to angiotensins and bradykinin in the human forearm. J Cardiovasc Pharmacol 2000;35:484-90. 
16. Lachurie ML, Azizi M, Guyene $\pi$, Alhenc-Gelas F, Menard J. Angiotensin-converting enzyme gene polymorphism has no influence on the circulating renin-angiotensin-aldosterone system or blood pressure in normotensive subjects. Circulation 1995;91:2933-42.

17. Steeds RP, Toole LO, Channer KS, Morice AH. Human vascular reactivity and polymorphisms of the angiotensin-converting enzyme and the angiotensin type 1 receptor genes. J Vasc Res 1999:36:445-55.

18. Danser AH, Derkx FH, Hense HW, Jeunemaitre X, Riegger GA. Schunkert H. Angiotensinogen (M235T) and angiotensin-converting enzyme (I/D) polymorphisms in association with plasma renin and prorenin levels. J Hypertens 1998;16:1879-83.

19. Morris BJ, Monaghan JC, Perich R, Stokes GS, Jackson B, Schrader AP. Genotypic influence on plasma dipeptidyl carboxypeptidase-1 activity in hypertensives. Clin Exp Pharmacol Physiol 1994:21:343-6.

20. Faure-Delanef L, Baudin B, Beneteau-Burnat B, Beaudoin JC, Giboudeau J, Cohen D. Plasma concentration, kinetic constants, and gene polymorphism of angiotensin I-converting enzyme in centenarians. Clin Chem 1998;44:2083-7.

21. Rigat B, Hubert C, Corvol P, Soubrier F. PCR detection of the insertion/deletion polymorphism of the human angiotensin converting enzyme gene (DCP1) (dipeptidyl carboxypeptidase 1). Nucleic Acids Res 1992:20:1433.

22. Shanmugam V, Sell KW, Saha BK. Mistyping ACE heterozygotes. PCR Methods Appl 1993;3:120-1.

23. Chadwick IG, OToole L, Morice AH, Yeo WW, Jackson PR, Ramsay LE. Pressor and hormonal responses to angiotensin I infusion in healthy subjects of different angiotensin-converting enzyme genotypes. J Cardiovasc Pharmacol 1997;29:485-9.

24. Danser AH, Deinum J, Osterop AP, Admiraal PJ, Schalekamp MA. Angiotensin I to angiotensin II conversion in the human forearm and leg. Effect of the angiotensin converting enzyme gene insertion/deletion polymorphism. J Hypertens 1999;17:1867-72.

25. Buikema H, Pinto YM, Rooks G, Grandjean JG, Schunkert H, van Gilst WH. The deletion polymorphism of the angiotensin-converting enzyme gene is related to phenotypic differences in human arteries. Eur Heart J 1996;17:787-94.

26. Hiraga H, Oshima T, Watanabe M, Ishida M, Ishida T, Shingu T, Kambe M, Matsuura H, Kajiyama G. Angiotensin 1-converting enzyme gene polymorphism and salt sensitivity in essential hypertension. Hypertension 1996;27:569-72.

27. Poch E, Gonzalez D, Giner V, Bragulat E, Coca A, de La Sierra A. Molecular basis of salt sensitivity in human hypertension. Evaluation of renin-angiotensin-aldosterone system gene polymorphisms. Hypertension 2001;38:1204-9. 


\section{Chapter 6}

\section{Genetic aspects of renal function in essential hypertension}

Wilko Spiering, Abraham A. Kroon, Peter W. de Leeuw 


\section{Abstract}

\section{Background}

A consistent finding in hypertensive patients is a reduced renal blood flow, which declines progressively with age. The pathophysiological background of this phenomenon has not been fully elucidated but likely includes the renin-angiotensin system. The present study was conducted to investigate whether renal hemodynamics in essential hypertensive patients depend on genetic factors related to the generation (angiotensin-converting enzyme (ACE) insertion/deletion (I/D) polymorphism) and effect (angiotensin II (AngII) type 1 receptor (AT1R) A1166C polymorphism) of Angll.

\section{Methods}

Effective renal plasma flow (ERPF), glomerular filtration rate (GFR), filtration fraction (FF), blood pressure, as well as renin, Angll, aldosterone, and ACE were studied in 212 essential hypertensives on a standardized low salt diet genotyped for the AT1R A1166C and ACE I/D polymorphisms.

\section{Results}

Mean age was $50 \pm 1$ years and comparable in all genotype groups. ERPF in AT1R CC patients $\left(338 \pm 17 \mathrm{~mL} / \mathrm{min} / 1.73 \mathrm{~m}^{2}\right)$ was significantly lower compared to $A A$ patients $\left(400 \pm 11 \mathrm{~mL} / \mathrm{min} / 1.73 \mathrm{~m}^{2} ; P<0.05\right)$ and so was GFR $\left(105 \pm 4 \mathrm{~mL} / \mathrm{min} / 1.73 \mathrm{~m}^{2}\right.$ vs. $111 \pm 2$ $\left.\mathrm{mL} / \mathrm{min} / 1.73 \mathrm{~m}^{2} ; P<0.05\right)$. FF was significantly higher in CC patients $(0.32 \pm 0.01)$ compared to $A A$ patients $(0.30 \pm 0.01 ; P<0.05)$. The ACE $1 / D$ polymorphism showed no association with renal function, as well as no significant interaction with the AT1R A1166C polymorphism. Besides the association of the ACE I/D polymorphism with ACE levels, no genotype effects on hormonal characteristics were found. The age-related decline in ERPF was comparable in all genotype groups but with a significantly lower intercept in CC patients.

\section{Conclusion}

The $C$ allele of the AT1R A $1166 C$ polymorphism is associated with impaired renal function. 


\section{Introduction}

One of the most consistent findings in hypertensive patients is a reduced renal blood flow (RBF).' Moreover, compared to normotensives, the age-related decline in $\mathrm{RBF}$ is markedly exaggerated in hypertension. ${ }^{1.2}$ Although the mechanisms which are responsible for these abnormalities have not been fully elucidated, several lines of evidence point towards increased intrarenal activity of the reninangiotensin system (RAS). ${ }^{3.4}$ Recently, we demonstrated that in hypertensive patients with the CC genotype of the angiotensin II (AngII) type 1 receptor (AT1R) A $1166 \mathrm{C}$ polymorphism, an increased renal sensitivity to Angl|5 and blunted (renal) responses to an AT1R antagonist ${ }^{6.7}$ can be found. Other studies have shown that this polymorphism is associated with diabetic nephropathy ${ }^{8}$ and the time from onset to end-stage renal disease.9.10 Except for increased sensitivity to Angll, enhanced production of this peptide may also be involved. In this respect it is noteworthy that the $D$ allele of the angiotensin-converting enzyme (ACE) insertion/deletion (I/D) polymorphism has also been found to be associated with diabetic ${ }^{11}$ and hypertensive nephropathy, ${ }^{12}$ and progression to chronic renal failure in (mainly) glomerular diseases.13,14 Moreover, it was found that both polymorphisms work synergistically as blood pressure variation and the risk for myocardial infarction is concerned. ${ }^{15,16}$ These findings prompted us to study renal hemodynamics, and in particular their relationship with age, in essential hypertensives in relation to these two polymorphisms. We hypothesized that both the AT1R C allele and ACE D allele are associated with impaired renal function.

\section{Methods}

\section{Patients}

All hypertensive patients who were referred for evaluation of their hypertension to the Hypertension Research Unit of the University Hospital Maastricht (secondary/tertiary referral center) between 1996 to 2002 underwent a detailed history and physical examination by an internist, followed by several laboratory assessments which included evaluation of renal plasma flow and glomerular filtration rate by means of para-aminohippurate (PAH) and inulin respectively. In addition, they were genotyped for the AT1R A $1166 C$ and ACE I/D polymorphisms. Patients entered the study if they fulfilled all the inclusion criteria: age between 18 and 80 years, Caucasian, hypertension according to World Health OrganizationInternational Society of Hypertension criteria ${ }^{17}$, able to stop antihypertensive medication for 3 weeks. Exclusion criteria were secondary hypertension, congestive heart failure (New York Heart Association classes II through IV), hepatic 
( $\geq$ Child-Pugh B) or renal insufficiency (creatinine clearance $<60 \mathrm{~mL} / \mathrm{min}$ ). In case of clinical suspicion of renal artery stenosis, renal angiography was performed. Detailed hormonal evaluation was conducted if clinical or biochemical signs suggested an endocrine form of hypertension. The protocol was approved by the Hospital Ethics Committee and all patients gave written informed consent. A total of 253 patients were studied during this time period.

\section{Genetic analysis}

DNA was extracted from whole blood using the QIAamp ${ }^{*}$ Blood Kit (Qiagen Inc., Valencia, CA, USA). The ACE I/D polymorphism was detected using the technique described by Rigat et al. ${ }^{18} \mathrm{~A}$ second PCR was performed to avoid misidentification of ID as DD. ${ }^{19}$ The AT1R A1166C polymorphism was genotyped by means of mutagenically separated PCR, as described earlier. ${ }^{5}$

\section{Renal function measurements}

Renal hemodynamics, i.e. effective renal plasma flow (ERPF) and glomerular filtration rate (GFR) were measured as the clearance of PAH (Merck Sharp \& Dohme, West Point, PA, USA) and inulin (Inutest, Laevosan Gesellschaft, Linz, Austria) respectivelv, using the continuous infusion method ${ }^{20}$ Both variables were corrected for body surface area and expressed as $\mathrm{mL} / \mathrm{min} / 1.73 \mathrm{~m}^{2}$. Effective renal blood flow (ERBF) was calculated using the formula: ERPF/(1-hematocrit). Filtration fraction (FF) was calculated as GFR/ERPF. Renal vascular resistance (RVR) was calculated according to the formula: (mean blood pressure/ERBF) 80,000 and expressed in dynes.sec. $\mathrm{cm}^{-5}$. Patients were investigated after a standardized low (55 mmol $\mathrm{Na}^{+} /$day) salt diet for 7 days, with a fixed potassium intake of 80 mmol/day. Compliance with the diet was checked by measuring sodium, potassium and creatinine output in a 24 hour urine collection obtained during the last day of the dietary period. A standardized low salt diet was chosen to: a) minimize the interindividual effects of sodium concentration on renal function, and b) obtain a situation of 'Angll dependent' renal function due to increased endogenous Angll levels. Antihypertensive medication had been stopped two weeks prior to the start of dietary intervention. Patients refrained from nicotine, alcohol, caffeine and caffeine-like substances from 8:00 PM the evening before the measurements. Clearance studies started at 8:30 AM after an overnight fast and patients remained supine during the entire session. In both arms an antecubital vein was cannulated with a $20 \mathrm{G}$ cannula. The one in the right arm was used for the infusion of PAH and inulin, whereas the cannula in the left arm was used for blood sampling. To ensure diuresis, subjects consumed $200 \mathrm{~mL}$ of water every hour until the last blood samples had been drawn. After a two-hour equilibration period, necessary to reach steady state plasma concentrations of PAH and inulin, 4 blood samples were taken with 15 minutes interval for the measurements of $\mathrm{PAH}$, inulin, 
and hematocrit. Systolic blood pressure (SBP), diastolic blood pressure (DBP), mean blood pressure (MBP) and heart rate (HR) were measured at a 3-minute time interval by a semi-automatic oscillometric device (Dinamap Vital Signs Monitor 1846 , Critikon, Tampa, FL, USA). In a subset of patients $(n=93)$ blood samples were drawn for determination of active plasma renin concentration (APRC), Angll, aldosterone, and ACE. All samples were stored at $-80^{\circ} \mathrm{C}$ until assay.

\section{Assay methods}

APRC was measured by a two-site direct immunoassay (Nichols Institute Diagnostics, San Juan Capistrano, CA, USA). ${ }^{21}$ For measuring Angll, blood samples were collected in tubes containing an inhibitor solution to prevent in vitro generation and degradation of this peptide,,$^{22}$ and spun immediately in a cooled centrifuge. Subsequently, the plasma was quickly frozen in liquid nitrogen. Hereafter, Angll was determined by 1251 radioimmunoassay (RIA) following extraction from plasma. Aldosterone was assayed by means of a solid-phase protein binding RIA (Diagnostic Products Corporation, Los Angeles, CA, USA). ${ }^{23}$ ACE, PAH and inulin levels were measured spectrophotometrically. 20.24 Intra- and interassay coefficients of variation of all assays were $<10 \%$. All samples from the same individual were assayed in a single run.

\section{Statistical analysis}

For each variable, normality in each genotype group was tested using Kolmogorov-Smirnov (with Lilliefors significance correction) or Shapiro-Wilk's test $(n<50)$ when applicable. When these tests indicated that data were not normally distributed, natural logarithmic transformation was applied. When after this transformation data were still not normally distributed, non-parametric tests were used for analysis. Comparisons of means were performed using One-Way analysis of variance or Kruskal-Wallis when appropriate. When these analyses yielded significant differences, further testing between genotype groups was done with Student's $t$-test or Mann-Whitney $U$ test with Bonferroni correction for multiple testing. The Chi-Square test was used for comparison of proportions. With simple linear regression analysis, determinants of renal function (i.e. ERPF, GFR and FF) were investigated. Effects of the genotypes, represented by dummy-variables, were assessed using the deviation from mean coding approach, ${ }^{25}$ which does not imply any genetic hypothesis. The interaction between both polymorphisms on renal function was tested using the following model: ERPF (or GFR, or FF) $=b_{0}+$ $b_{1} X+b_{2} Y+b_{3} X Y$, in which $b_{0}$ represents a constant variable, $X$ the risk allele of polymorphism $X, Y$ the risk allele of polymorphism $Y$, and $X Y$ the interaction between the two. The study had a power of $>0.75$ to detect a difference between the different genotype groups of 63 and $13 \mathrm{~mL} / \mathrm{min} / 1.73 \mathrm{~m}^{2}$ in mean ERPF and GFR, respectively. Results are expressed as means \pm standard error of the mean 
(SEM). A P-value of less than 0.05 was considered to be statistically significant. Statistical analyses were performed using SPSS 11.0 for Windows (SPSS Inc., Chicago, IL, USA).

\section{Results}

\section{Characteristics of the patients}

Forty-one of the 253 patients exhibited some degree of renal artery stenosis and were, therefore, excluded for further analysis. The remaining 212 patients included 114 men (54\%) and were comparable for sex, age, body mass index (BMI), blood pressure, HR and plasma creatinine with respect to both polymorphisms (Tables 6.1 and 6.2).

Table 6.1. Characteristics of the study population with respect to AT1R A1166C polymorphism.

\begin{tabular}{lccc} 
& AA & AC & CC \\
\hline Number, $n$ (\%) & $114(53.8)$ & $72(34.0)$ & $26(12.3)$ \\
Males/females, $n$ & $58 / 56$ & $41 / 31$ & $15 / 11$ \\
Age, years & $50 \pm 1$ & $50 \pm 1$ & $52 \pm 3$ \\
BMI, $\mathrm{kg} / \mathrm{m}^{2}$ & $27.0 \pm 0.4$ & $27.4 \pm 0.5$ & $26.6 \pm 0.9$ \\
$\mathrm{SBP}, \mathrm{mmHg}$ & $159 \pm 5$ & $173 \pm 6$ & $160 \pm 5$ \\
$\mathrm{DBP}, \mathrm{mmHg}$ & $91 \pm 2$ & $95 \pm 3$ & $93 \pm 3$ \\
Heart rate, beats/min & $66 \pm 2$ & $68 \pm 2$ & $65 \pm 2$ \\
Serum creatinine, $\mu$ mol/ & $84 \pm 2$ & $83 \pm 2$ & $86 \pm 4$ \\
n: number; BMl: body mass index; SBP; systolic blood pressure; DBP: diastolic blood pressure.
\end{tabular}

Table 6.2. Characteristics of the study population with respect to ACE I/D polymorphism.

\begin{tabular}{lccc|}
\hline & II & ID & DD \\
\hline Number, $n$ (\%) & $28(13.2)$ & $115(54.2)$ & $69(32.5)$ \\
Males/females, $n$ & $12 / 16$ & $57 / 58$ & $45 / 24$ \\
Age, years & $51 \pm 3$ & $49 \pm 1$ & $53 \pm 1$ \\
$\mathrm{BML}, \mathrm{kg} / \mathrm{m}^{2}$ & $27.3 \pm 0.8$ & $26.8 \pm 0.4$ & $27.6 \pm 0.5$ \\
$\mathrm{SBP}, \mathrm{mmHg}$ & $155 \pm 7$ & $166 \pm 4$ & $165 \pm 6$ \\
$\mathrm{DBP}, \mathrm{mmHg}$ & $90 \pm 4$ & $94 \pm 2$ & $94 \pm 2$ \\
Heart rate, beats/min & $65 \pm 2$ & $65 \pm 2$ & $68 \pm 2$ \\
Serum creatinine, $\mu$ mol/ & $82 \pm 4$ & $82 \pm 2$ & $88 \pm 2$ \\
n: number; BMl: body mass index; SBP: systolic blood pressure; DBP: diastolic blood pressure.
\end{tabular}




\section{Renal hemodynamics and hormonal characteristics}

\section{Whole population}

Mean ERPF for the whole population was $384 \pm 8 \mathrm{~mL} / \mathrm{min} / 1.73 \mathrm{~m}^{2}$. Independent determinants of ERPF were age $\left(R^{2}=0.142 ; P<0.001\right)$, gender $\left(R^{2}=0.022 ; P=0.032\right)$, BMI $\left(R^{2}=0.039 ; P=0.004\right)$, SBP $\left(R^{2}=0.068 ; P=0.037\right)$, and AT1 $C$ allele $\left(R^{2}=0.028\right.$; $P=0.014)$. Mean GFR for the whole population was $110 \pm 2 \mathrm{~mL} / \mathrm{min} / 1.73 \mathrm{~m}^{2}$. Independent determinants of GFR (after logarithmic transformation) were age $\left(R^{2}=0.16 ; P<0.001\right)$, gender $\left(R^{2}=0.027 ; P=0.018\right), B M I\left(R^{2}=0.042 ; P=0.003\right)$, and $A T 1 R$ $C$ allele $\left(R^{2}=0.03 ; P=0.012\right)$. Mean $F F$ for the whole population was $0.30 \pm 0.01$. Independent determinants of $\mathrm{FF}$ (after logarithmic transformation) were age $\left(R^{2}=0.16 ; P<0.001\right)$, gender $\left(R^{2}=0.027 ; P=0.018\right), B M I\left(R^{2}=0.042 ; P=0.003\right)$, and $A T 1 R$ C allele $\left(R^{2}=0.03 ; P=0.012\right)$.

\section{ATIRA1166C polymorphism}

As shown in Table 6.3, ERPF in CC patients $\left(338 \pm 17 \mathrm{~mL} / \mathrm{min} / 1.73 \mathrm{~m}^{2}\right)$ was significantly lower compared to AA patients $\left(400 \pm 11 \mathrm{~mL} / \mathrm{min} / 1.73 \mathrm{~m}^{2} ; P<0.05\right)$. The association of the AT1R C allele with ERPF remained significant after adjustment for age, gender, and BMI. No significant interaction between the AT1R $\mathrm{C}$ allele and the major determinant of ERPF, age, was present (Figure 6.1). Also no significant interactions between the AT1R C allele and gender or BMI on ERPF were found. GFR was significantly lower in CC patients $\left(105 \pm 4 \mathrm{~mL} / \mathrm{min} / 1.73 \mathrm{~m}^{2}\right)$ compared to AA patients $\left(111 \pm 2 \mathrm{~mL} / \mathrm{min} / 1.73 \mathrm{~m}^{2} ; P<0.05\right)$. The association of the AT1R C allele with GFR also remained significant after adjustment for age, gender, and BMI, again without a significant interaction between the AT1R C allele and age, gender, or BMI on GFR. Finally, FF was significantly higher in CC patients $(0.32 \pm 0.01)$ compared to AA patients $(0.30 \pm 0.01 ; P<0.05)$ with the association of the AT1R C allele with FF remaining significant after adjustment for age, gender, and BMI. No significant interaction between the AT1R C allele and age, gender, or $\mathrm{BMI}$ on FF was present. Angll concentrations in $\mathrm{AC}$ patients $(21.9 \pm 2.9 \mathrm{pmol} / \mathrm{L})$ were significantly higher compared to those in AA patients $(19.2 \pm 5.4 \mathrm{pmol} / \mathrm{L} ; P<0.05$; Table 6.3), but comparable to those in CC patients $(18.4 \pm 4.6 \mathrm{pmol} / \mathrm{L} ; P=0.09 ;$ Table 6.3). Aldosterone in $A A(0.32 \pm 0.03 \mathrm{nmol} / \mathrm{L})$ and $C C(0.25 \pm 0.03 \mathrm{nmol} / \mathrm{L})$ were both signifcantly lower compared to $A C$ patients $(0.37 \pm 0.03 \mathrm{nmol} / \mathrm{L} ; P<0.05$ vs. $A A$ and CC; Table 6.3). No significant differences between genotype groups were found for APRC and ACE (Table 6.3).

\section{ACE I/D polymorphism}

No differences in renal hemodynamics, APRC, and Angll were found between the genotype groups (Table 6.4). Aldosterone in DD patients $(0.37 \pm 0.04 \mathrm{nmol} / \mathrm{L})$ was slightly higher compared to II patients $(0.30 \pm 0.05 \mathrm{nmol} / \mathrm{L} ; P=0.08)$ and ID patients $(0.31 \pm 0.03 \mathrm{nmol} / \mathrm{L} ; P=0.06$; Table 6.3$)$. As would be expected, ACE levels in DD ( $19 \pm 1 \mathrm{U} / \mathrm{L} ; P<0.05$ vs. II and ID) and ID (16 $\pm 1 \mathrm{U} / \mathrm{L} ; P<0.05$ vs. II and $D D)$ patients were significantly higher compared to those in II patients ( $11 \pm 1 \mathrm{U} / \mathrm{L}$; Table 6.4). 
Table 6.3. Renal hemodynamics and hormonal characteristics with respect to AT1R A1166C polymorphism.

\begin{tabular}{|c|c|c|c|}
\hline & AA & $A C$ & CC \\
\hline Urinary $\mathrm{Na}^{*}, \mathrm{mmol} / 24 \mathrm{hr}$ & $80 \pm 5$ & $80 \pm 8$ & $62 \pm 9$ \\
\hline ERPF, $\mathrm{mL} / \mathrm{min} / 1.73 \mathrm{~m}^{2}$ & $400 \pm 11$ & $376 \pm 15$ & $337 \pm 17^{*}$ \\
\hline GFR, $\mathrm{mL} / \mathrm{min} / 1.73 \mathrm{~m}^{2}$ & $111 \pm 2$ & $111 \pm 3$ & $105 \pm 4^{+}$ \\
\hline FF & $0.30 \pm 0.01$ & $0.30 \pm 0.01$ & $0.32 \pm 0.01 t$ \\
\hline RVR, dynes $\cdot \mathrm{sec}^{\mathrm{cm}} \mathrm{cm}^{-5}$ & $13484 \pm 626$ & $13049 \pm 920$ & $15082 \pm 767$ \\
\hline APRC, $m U / L$ & $20.1 \pm 1.6$ & $22.3 \pm 2.3$ & $17.6 \pm 2.0$ \\
\hline Angll, pmol/L & $19.2 \pm 5.4$ & $21.9 \pm 2.9^{*}$ & $18.4 \pm 4.6$ \\
\hline Aldosterone, $\mathrm{nmol} / \mathrm{L}$ & $0.32 \pm 0.03$ & $0.37 \pm 0.03^{*}$ & $0.25 \pm 0.03^{\prime \prime}$ \\
\hline Aldosterone/APRC ratio & $0.022 \pm 0.003$ & $0.024 \pm 0.004$ & $0.016 \pm 0.002$ \\
\hline $\mathrm{ACE}, \mathrm{U} / \mathrm{L}$ & $18 \pm 1$ & $15 \pm 1$ & $18 \pm 1$ \\
\hline
\end{tabular}

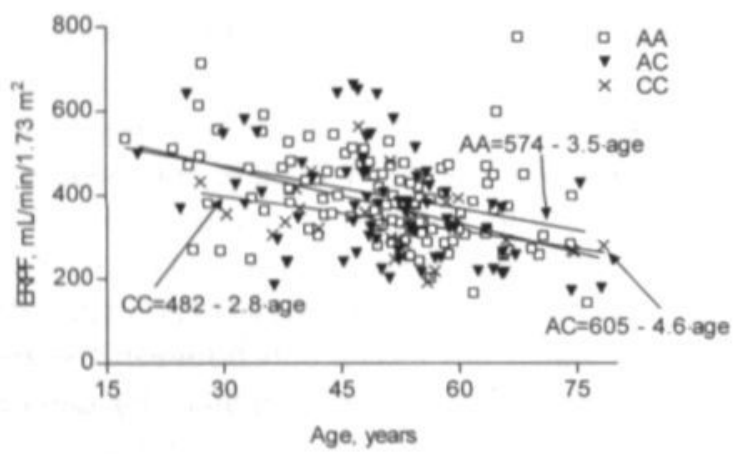

Figure 6.1. Relationship between ERPF and age with respect to AT1R A1166C polymorphism.

Table 6.4. Renal hemodynamics and hormonal characteristics with respect to ACE I/D polymorphism.

\begin{tabular}{|c|c|c|c|}
\hline 1 & AA & $A C$ & cC \\
\hline Urinary $\mathrm{Na}^{+}, \mathrm{mmol} / 24 \mathrm{hr}$ & $78 \pm 8$ & $75 \pm 6$ & $81 \pm 8$ \\
\hline ERPF, $\mathrm{mL} / \mathrm{min} / 1.73 \mathrm{~m}^{2}$ & $401 \pm 25$ & $383 \pm 11$ & $378 \pm 15$ \\
\hline GFR, $\mathrm{mL} / \mathrm{min} / 1.73 \mathrm{~m}^{2}$ & $114 \pm 5$ & $109 \pm 2$ & $109 \pm 3$ \\
\hline FF & $0.31 \pm 0.02$ & $0.30 \pm 0.01$ & $0.31 \pm 0.01$ \\
\hline RVR, dynes $\cdot \mathrm{sec}^{\mathrm{cm}} \mathrm{cm}^{\mathrm{s}}$ & $12837 \pm 1078$ & $14021 \pm 665$ & $14037 \pm 663$ \\
\hline APRC, $m U / L$ & $21.1 \pm 3.2$ & $19.7 \pm 1.5$ & $20.9 \pm 2.2$ \\
\hline Angll, $\mathrm{pmol} / \mathrm{L}$ & $13.9 \pm 3.7$ & $19.7 \pm 2.9$ & $21.7 \pm 5.6$ \\
\hline Aldosterone, $\mathrm{nmol} / \mathrm{L}$ & $0.30 \pm 0.05$ & $0.31 \pm 0.03$ & $0.37 \pm 0.04$ \\
\hline Aldosterone/APRC ratio & $0.023 \pm 0.007$ & $0.020 \pm 0.002$ & $0.024 \pm 0.003$ \\
\hline ACE, U/L & $11 \pm 1$ & $16 \pm 1^{\circ}$ & $19 \pm 1^{* 1}$ \\
\hline
\end{tabular}




\section{Interaction between ATIRA1166C and ACE I/D polymorphism}

Table 6.5 shows the interaction of the AT1R C and ACE D alleles on ERPF and GFR. No interaction of both risk alleles on ERPF $(P=0.918)$ and GFR $(P=0.824)$ was found.

Table 6.5. Interaction of AT1R A1 166C and ACE I/D polymorphisms on ERPF and GFR.

\begin{tabular}{|c|c|c|c|c|}
\hline \multirow[b]{2}{*}{ ACE I/D } & & \multicolumn{3}{|c|}{ AT1R A1166C } \\
\hline & & AA & $A C$ & CC \\
\hline \multirow[t]{2}{*}{ II } & ERPF & $436 \pm 37$ & $393 \pm 44$ & $305 \pm 20$ \\
\hline & GFR & $113 \pm 8$ & $115 \pm 8$ & $114 \pm 15$ \\
\hline \multirow[t]{2}{*}{ ID } & ERP & $389 \pm 14$ & $393 \pm 22$ & $347 \pm 22$ \\
\hline & GFR & $110 \pm 3$ & $113 \pm 5$ & $102 \pm 4$ \\
\hline \multirow[t]{2}{*}{ DD } & ERPF & $405 \pm 21$ & $347 \pm 24$ & $327 \pm 31$ \\
\hline & GFR & $112 \pm 5$ & $108 \pm 4$ & $112 \pm 10$ \\
\hline
\end{tabular}

\section{Discussion}

This study investigated renal hemodynamics and hormonal characteristics with respect to the AT1R A1166C and ACE I/D polymorphisms. The results show that the AT1R C allele is independently associated with reduced ERPF and GFR, and increased FF. No significant interactions between the AT1R C allele and known determinants of renal function (age, gender, BMI, blood pressure) were present. On the other hand, no differences in renal hemodynamics with respect to the ACE I/D polymorphism were found. Lastly, interactions of the AT1R C and ACE D alleles which have previously been reported could not be confirmed for the phenotypes studied here.

As far as we know this is the first, large sample size study that investigated renal hemodynamics, using clearance techniques, with respect to both the AT1R $A 1166 C$ and ACE I/D polymorphisms. The gold standard in renal function assessment still are clearance studies of inulin to estimate GFR and PAH (or analogue) to estimate RPF.

One study found that the average time from the onset of renal disease to endstage renal failure in patients with the AT1R C allele was significantly shorter than in those with the AA genotype (6.3 vs. 13 years)..$^{9}$ In line with our data, Miller et al. showed in a small study of 66 healthy patients (of which 7 had the CC genotype) that the combined AC/CC genotype group had a lower GFR and ERPF, and an increased FF and RVR compared to AA subjects. ${ }^{26}$ However, a comparable study by Hilgers et al. in male normotensives or mildly hypertensives could not confirm this. ${ }^{27}$ These two studies both investigated normotensives on a high salt diet, whereas we studied hypertensives on a low salt diet. As the frequency of the $C$ 
allele is higher in hypertensives ${ }^{28}$ we were able to collect more CC patients. Both Miller et al. and Hilgers et al. chose to combine AC and CC subjects in one group. This however, is incorrect as the inheritance is recessive. ${ }^{5}$ This could be a possible explanation for the negative finding of Hilgers et al. The decreased ERPF and GFR in the study of Miller et al. that was found in subjects on a high salt diet, a finding that we could confirm, ${ }^{5}$ refutes a (major) confounding effect of salt intake on the association of the AT1R A1166C polymorphism with impaired renal function. Urinary sodium excretion was not different between the AT1R genotype groups and adding this variable in the regression model did not change the positive association of the AT1R C allele with ERPF.

Our findings of a negative association of the ACE I/D polymorphism with renal function is corroborated by two other studies. One study in a general population showed that overall renal function, estimated by means of measured and calculated creatinine clearance, was not significantly different between the different ACE I/D genotypes. ${ }^{29}$ Further subgroup analyses revealed that the risk for mild renal dysfunction $\left(<60 \mathrm{~mL} / \mathrm{min} / 1.73 \mathrm{~m}^{2}\right)$ was increased in $D$ allele carriers, but only when the $\alpha$-adducin Trp allele was present. As creatinine clearance is a fallible index of GFR, ${ }^{30}$ especially in the lower ranges, the significance of these findings is debatable. A second study used radioisotopes for measuring ERPF and GFR and could also not find a positive association of the ACE I/D polymorphism with renal function. ${ }^{31}$ If anything, the single gene effects on renal function of the ACE D allele seem to be minor.

By constricting the efferent arteriole of the glomerulus, Angll increases glomerular pressure to maintain GFR. As a result, ERPF decreases while FF increases. Our observation of a reduced ERPF and GFR and increased FF in AT1R C allele carriers fits well in the hypothesis of increased Angll sensitivity that we and others showed earlier. ${ }^{5,6,32-34}$ Besides increased Angll sensitivity in the acute situation, ${ }^{5,6}$ we recently showed that the AT1R A1166C polymorphism was associated with blunted blood pressure responses to losartan-based treatment in a 12 week trial.? Others showed increased vascular responsiveness of coronary and internal mammarian arteries to different stimuli in patients carrying the $C$ allele. ${ }^{32-34}$ Thus, we now have growing evidence that the C allele of the AT1R A1166C polymorphism is indeed associated with increased Angll sensitivity. Furthermore, our data suggest that the genetic effect of the $C$ allelle is a recessive one since $A C$ carriers behave rather similarly as AA subjects.

Regression analysis showed that apart from known determinants of renal function (age, gender, BMI, and blood pressure), the AT1R C allele is an independent factor determining ERPF, GFR and FF. Also after adjusting for these covariates the associations remained. Of these covariates, age is still the major factor determining renal function. The effect of the ATIR C allele on renal function is comparable with gender, BMI and blood pressure. Since in our regression model these determinants together only explained about $20 \%$ of the variation in renal 
function, there must be other influences on the kidney that still have to be elucidated. More studies are needed to unravel other genetic factors involved in renal function regulation but like in other complex traits (e.g. blood pressure) one major gene effect is not to be expected.

Although the slope of the regression line of the relationship between ERPF and age in CC patients compared to AA and AC patients seemed to be less steep, no significant interaction between the $C$ allele and age was present. We suspect that CC subjects already have impaired renal function at birth, but that the agedependent decline is not accelerated by this allele. Taking this a step further, one could even hypothesize that due to the increased Angll sensitivity, this polymorphism leads to impaired intra-uterine renal development and, therefore, that these subjects start their lives with impaired renal reserve. On the other hand, however, it cannot be ruled out that subjects with a lower GFR experience a more stable renal function in the long term as compared with those with a higher GFR (and probably higher glomerular pressure). Of course, other studies are necessary to explore these possibilities in greater detail.

Earlier studies reported that the AT1R A1166C and ACE I/D polymorphisms work synergistically on blood pressure variation and the risk for myocardial infarction, ${ }^{15,16}$ and for this reason we were interested in the interaction of both polymorphisms on renal function. However, we could not confirm such an interaction, just as we failed to do so with respect to blood pressure. ${ }^{35}$

It remains elusive, why the C allele of the AT1R A1166C polymorphism is associated with increased sensitivity to Angll and, in the end, an increased incidence of cardiovascular disease. 16,28,36-44 $\mathrm{As} \mathrm{we}^{6}$ and others ${ }^{45}$ did not find differences in the number of platelet AT1R binding sites $\left(B_{\max }\right)$ and Angll affinity $\left(K_{D}\right)$, differences probably cannot be explained by the number and function of the AT1R. On the other hand, one should realize that the platelet model is just a surrogate model for the RAS in the systemic circulation, as well as in the kidneys and adrenals. With a low number of AT1Rs $45-47$ per platelet (about 4 to 6) the limitations of this model in showing prominent differences in AT1R number and function are clear. Because this polymorphism is located in the uncoding $3^{\prime}$-region of the AT1R gene it could be in linkage disequilibrium with a coding mutation nearby. However, Poirier et al. rescanned the AT1R gene, but did not find new variants which could affect the regulation of the gene in response to Angll.48 Furthermore, the binding of AUF1, a protein that affects AT1R mRNA stability through binding to AU-rich regions of the uncoding 3 '-untranslated region of the mRNA, is not affected by this polymorphism. ${ }^{49}$

In conclusion, the present study shows that the C allele of the AT1R A1166C polymorphism is associated with reduced ERPF and GFR, and increased FF. As the presence of the AT1R C allele and age are both independent factors determining ERPF, it is conceivable that CC subjects are prone to develop hypertension at an earlier stage than those carrying one or two A alleles. 


\section{References}

1. Bauer $\mathrm{JH}$, Brooks CS, Burch RN. Renal function and hemodynamic studies in low- and normalrenin essential hypertension. Arch Intern Med 1982;142:1317-23.

2. London GM, Safar ME, Sassard JE, Levenson JA, Simon AC. Renal and systemic hemodynamics in sustained essential hypertension. Hypertension 1984;6:743-54.

3. Hollenberg NK, Adams DF. The renal circulation in hypertensive disease. Am J Med 1976;60: 773-84.

4. Ljungman S. Renal function, sodium excretion and the renin-angiotensin-aldosterone system in relation to blood pressure. An epidemiological and physiological study. Acta Med Scand Suppl 1982;663:108.

5. Spiering W, Kroon AA, Fuss-Lejeune MM, Daemen MJ, de Leeuw PW. Angiotensin II sensitivity is associated with the angiotensin II type 1 receptor $A(1166) C$ polymorphism in essential hypertensives on a high sodium diet. Hypertension 2000;36:411-6.

6. Spiering W, Kroon AA, Fuss-Lejeune MJ, de Leeuw PW. Genetic contribution to the acute effects of angiotensin II type 1 receptor blockade. Submitted 2004.

7. Spiering W, Kroon AA, de Leeuw PW. Genetic contribution to the chronic effects of angiotensin II type 1 receptor blockade. Submitted 2004.

8. Fradin S, Goulet-Salmon B, Chantepie M, Grandhomme F, Morello R, Jauzac P, Reznik Y. Relationship between polymorphisms in the renin-angiotensin system and nephropathy in type 2 diabetic patients. Diabetes Metab 2002;28:27-32.

9. Buraczynska M, Ksiazek P, Zaluska W, Spasiewicz D, Nowicka T, Ksiazek A. Angiotensin II type 1 receptor gene polymorphism in end-stage renal disease. Nephron 2002;92:51-5.

10. Coll E, Campos B, Gonzalez-Nunez D, Botey A, Poch E. Association between the A1166C polymorphism of the angiotensin II receptor type 1 and progression of chronic renal insufficiency. J Nephrol 2003;16:357-64.

11. Marre M, Bernadet P, Gallois Y, Savagner F, Guyene TT, Hallab M, Cambien F, Passa P, AlhencGelas F. Relationships between angiotensin I converting enzyme gene polymorphism, plasma levels, and diabetic retinal and renal complications. Diabetes 1994;43:384-8.

12. Kario K, Kanai N, Nishiuma S, Fujii T, Saito K, Matsuo T, Matsuo M, Shimada K. Hypertensive nephropathy and the gene for angiotensin-converting enzyme. Arterioscler Thromb Vasc Biol 1997;17:252-6.

13. Harden PN, Geddes C, Rowe PA, Mcllroy JH, Boulton-Jones M, Rodger RS, Junor BJ, Briggs JD, Connell JM, Jardine AG. Polymorphisms in angiotensin-converting-enzyme gene and progression of IgA nephropathy. Lancet 1995:345:1540-2.

14. McLaughlin KJ, Harden PN, Ueda S, Boulton-Jones JM, Connell JM, Jardine AG. The role of genetic polymorphisms of angiotensin-converting enzyme in the progression of renal diseases. Hypertension 1996;28:912-5.

15. Alvarez R, Reguero JR, Batalla A, Iglesias-Cubero G, Cortina A, Alvarez V, Coto E. Angiotensinconverting enzyme and angiotensin II receptor 1 polymorphisms: association with early coronary disease. Cardiovasc Res 1998;40:375-9.

16. Tiret L, Bonnardeaux A, Poirier O, Ricard S, Marques-Vidal P, Evans A, Arveiler D, Luc G, Kee F, Ducimetiere P, et al. Synergistic effects of angiotensin-converting enzyme and angiotensin-II type 1 receptor gene polymorphisms on risk of myocardial infarction. Lancet 1994;344:910-3.

17. 1999 World Health Organization-International Society of Hypertension Guidelines for the Management of Hypertension. Guidelines Subcommittee. J Hypertens 1999;17:151-83.

18. Rigat B, Hubert C, Corvol P, Soubrier F. PCR detection of the insertion/deletion polymorphism of the human angiotensin converting enzyme gene (DCP1) (dipeptidyl carboxypeptidase 1). Nucleic Acids Res 1992:20:1433.

19. Shanmugam V, Sell KW, Saha BK. Mistyping ACE heterozygotes. PCR Methods App/ 1993;3:120-1. 
20. Cole BR, Giangiacomo J, Ingelfinger JR, Robson AM. Measurement of renal function without urine collection. A critical evaluation of the constant-infusion technic for determination of inulin and para-aminohippurate. N Engl J Med 1972;287:1109-14.

21. Simon D, Hartmann DJ, Badouaille G, Caillot G, Guyenne TT, Corvol P, Pau B, Marchand J. Two-site direct immunoassay specific for active renin. Clin Chem 1992;38:1959-62.

22. Nussberger J, Brunner DB, Waeber B, Brunner HR. True versus immunoreactive angiotensin II in human plasma. Hypertension 1985;7:11-7.

23. Kubasik NP, Warren K, Sine HE. Evaluation of a new commercial radioassay kit for aldosterone using an iodinated tracer. Clin Biochem 1979;12:59-61.

24. Brun C. A rapid method for the determination of para-aminohippuric acid in kidney function tests. J Lab Clin Med 1951;37:955-8.

25. Hosmer DW, Lemeshow S. Interpretation of the fitted logistic regression model. In: Applied logistic regression. 2nd ed. New York: Wiley-Interscience; 2000:47-90.

26. Miller JA, Thai K, Scholey JW. Angiotensin II type 1 receptor gene polymorphism predicts response to losartan and angiotensin II. Kidney Int 1999;56:2173-80.

27. Hilgers KF, Langenfeld MR, Schlaich M, Veelken R, Schmieder RE. 1166 A/C polymorphism of the angiotensin II type 1 receptor gene and the response to short-term infusion of angiotensin II. Circulation 1999;100:1394-9.

28. Bonnardeaux A, Davies E, Jeunemaitre X, Fery I, Charru A, Clauser E, Tiret L, Cambien F, Corvol P, Soubrier F. Angiotensin II type 1 receptor gene polymorphisms in human essential hypertension. Hypertension 1994;24:63-9.

29. Wang JG, Staessen JA, Tizzoni L, Brand E, Birkenhager WH, Fagard R, Herrmann SM, Bianchi G. Renal function in relation to three candidate genes. Am J Kidney Dis 2001;38:1158-68.

30. Levey AS, Bosch JP, Lewis JB, Greene T, Rogers N, Roth D. A more accurate method to estimate glomerular filtration rate from serum creatinine: a new prediction equation. Modification of Diet in Renal Disease Study Group. Ann Intern Med 1999;130:461-70.

31. Fernandez-Llama P, Poch E, Oriola J, Botey A, Coll E, Darnell A, Rivera F, Revert L. Angiotensin converting enzyme gene $\mathrm{I} / \mathrm{D}$ polymorphism in essential hypertension and nephroangiosclerosis. Kidney Int 1998;53:1743-7.

32. Amant C, Hamon M, Bauters C, Richard F, Helbecque N, McFadden EP, Escudero X, Lablanche JM, Amouyel P, Bertrand ME. The angiotensin II type 1 receptor gene polymorphism is associated with coronary artery vasoconstriction. J Am Coll Cardiol 1997;29:486-90.

33. Henrion D, Amant C, Benessiano J, Philip I, Plantefeve G, Chatel D, Hwas U, Desmont JM, Durand G, Amouyel P, Levy BI. Angiotensin II type 1 receptor gene polymorphism is associated with an increased vascular reactivity in the human mammary artery in vitro. J Vasc Res 1998;35:356-62.

34. van Geel PP, Pinto YM, Voors AA, Buikema H, Oosterga M, Crijns HJ, van Gilst WH. Angiotensin II type 1 receptor $A 1166 C$ gene polymorphism is associated with an increased response to angiotensin II in human arteries. Hypertension 2000;35:717-21.

35. Henskens LH, Spiering W, Stoffers HE, Soomers FL, Vlietinck RF, de Leeuw PW, Kroon AA. Effects of ACE I/D and AT1R-A1166C polymorphisms on blood pressure in a healthy normotensive primary care population: first results of the Hippocates study. J Hypertens 2003;21:81-6.

36. Benetos A, Topouchian J, Ricard S, Gautier S, Bonnardeaux A, Asmar R, Poirier O, Soubrier F, Safar M, Cambien F. Influence of angiotensin II type 1 receptor polymorphism on aortic stiffness in never-treated hypertensive patients. Hypertension 1995;26:44-7.

37. Hingorani AD, Jia H, Stevens PA, Hopper R, Dickerson JE, Brown MJ. Renin-angiotensin system gene polymorphisms influence blood pressure and the response to angiotensin converting enzyme inhibition. J Hypertens 1995;13:1602-9.

38. Nakauchi Y, Suehiro T, Yamamoto M, Yasuoka N, Arii K, Kumon Y, Hamashige N, Hashimoto K. Significance of angiotensin I-converting enzyme and angiotensin II type 1 receptor gene polymorphisms as risk factors for coronary heart disease. Atherosclerosis 1996;125:161-9.

39. Berge KE, Bakken A, Bohn M, Erikssen J, Berg K. A DNA polymorphism at the angiotensin II type 1 receptor (AT1R) locus and myocardial infarction. Clin Genet 1997;52:71-6.

40. Doria A, Onuma T, Warram JH, Krolewski AS. Synergistic effect of angiotensin II type 1 receptor genotype and poor glycaemic control on risk of nephropathy in IDDM. Diabetologia 1997;40:1293-9. 
41. Wang WY, Zee RY, Morris BJ. Association of angiotensin II type 1 receptor gene polymorphism with essential hypertension. Clin Genet 1997;51:31-4.

42. Osterop AP, Kofflard MJ, Sandkuijl LA, ten Cate FJ, Krams R, Schalekamp MA, Danser AH. AT1 receptor A/C1166 polymorphism contributes to cardiac hypertrophy in subjects with hypertrophic cardiomyopathy. Hypertension 1998;32:825-30.

43. Szombathy T, Szalai C, Katalin B, Palicz T, Romics L, Csaszar A. Association of angiotensin II type 1 receptor polymorphism with resistant essential hypertension. Clin Chim Acta 1998;269:91-100.

44. Kainulainen K, Perola M, Terwilliger J, Kaprio J, Koskenvuo M, Syvanen AC, Vartiainen E, Peltonen L, Kontula K. Evidence for involvement of the type 1 angiotensin II receptor locus in essential hypertension. Hypertension 1999;33:844-9.

45. Paillard F, Chansel D, Brand E, Benetos A, Thomas F, Czekalski S, Ardaillou R, Soubrier F. Genotype-phenotype relationships for the renin-angiotensin-aldosterone system in a normal population. Hypertension 1999;34:423-9.

46. Makarious M, Pawlak M, Campbell LV, Timmermans V, Duggan K, Charlesworth JA, Macdonald GJ. The platelet angiotensin II receptor in type I diabetes: studies in patients with and without nephropathy. Eur J Clin Invest 1993;23:517-21.

47. Mann JF, Sis J, Ritz E. 125I-Angiotensin II binding to human blood cells. J Hypertens 1985;3:131-7.

48. Poirier O, Georges JL, Ricard S, Arveiler D, Ruidavets JB, Luc G, Evans A, Cambien F, Tiret L. New polymorphisms of the angiotensin II type 1 receptor gene and their associations with myocardial infarction and blood pressure: the ECTIM study. Etude Cas-Temoin de I'Infarctus du Myocarde. J Hypertens 1998;16:1443-7.

49. Pende A, Giacche M, Castigliola L, Contini L, Passerone G, Patrone M, Port JD, Lotti G. Characterization of the binding of the RNA-binding protein AUF1 to the human AT(1) receptor mRNA. Biochem Biophys Res Commun 1999;266:609-14. 


\section{Chapter 7}

\section{Angiotensin II sensitivity is associated with the angiotensin II type 1 receptor A1166C polymorphism in essential hypertensives on a high sodium diet}

Wilko Spiering, Abraham A. Kroon, Monique J. Fuss-Lejeune, Mat J. Daemen, Peter W. de Leeuw

Hypertension 2000;36:411-6. 


\section{Abstract}

\section{Background}

Several investigations have shown heterogeneity in the functional responses to angiotensin II (AngII) in patients with essential hypertension. The present study was initiated to evaluate whether the $\mathrm{A} 1166 \mathrm{C}$ polymorphism of the Angll type 1 receptor (AT1R) gene contributes to this variability in Angll responses.

\section{Methods}

After 7 days high sodium diet $(220 \mathrm{mmol} \mathrm{Na} /$ day) we measured in 42 essential hypertensive patients blood pressure, heart rate (HR), effective renal plasma flow (ERPF), glomerular filtration rate (GFR), active plasma renin concentration (APRC), aldosterone, and atrial natriuretic peptide (ANP) before and during Angll infusion (increasing doses of 0.3, 1.0 and $3.0 \mathrm{ng} / \mathrm{kg} / \mathrm{min}$ ). Calculated variables were filtration fraction (FF) and renal vascular resistance (RVR). Patients in the three genotype groups (AA: $n=14 ; A C: n=17 ; C C: n=11$ ) were matched for sex, age, and body mass index.

\section{Results}

At baseline, CC patients had decreased GFR $(P=0.06)$ and aldosterone $(P<0.05)$, and increased ANP $(P<0.05)$ as compared to AA patients. Moreover, responses of ERPF, GFR and RVR to the lowest concentration of Angll $(0.3 \mathrm{ng} / \mathrm{kg} / \mathrm{min})$ were more pronounced in CC patients compared to AA patients (ERPF/GFR: $P<0.05$; RVR: $P=0.07$ ), whereas maximal responses were all comparable between the groups. HR was decreased at all levels of Angll infusion in CC patients, while it did not change in AA or AC patients. There were no differences in responses of APRC, aldosterone, and ANP to Angll between the three groups.

\section{Conclusion}

From these data we conclude that the $C$ allele of the AT1R A1166C polymorphism is associated with increased sensitivity, but not reactivity to Angll. 


\section{Introduction}

One of the striking features of essential hypertension is the heterogeneity of patients' responses to angiotensin II (AngII).' This is not only apparent in situations where the formation or action of endogenous Angll is blocked, but also when exogenous Angll is administered. Besides interindividual differences in responses to Angll, there is marked variability in tissue sensitivity to this peptide. For instance, we and others have shown that the kidney is more sensitive to Angll than the systemic vasculature and that an enhanced responsiveness cannot be explained satisfactorily from differences in plasma levels of Angll.2.3 Ultimately, however, it is the Angll type 1 receptor (AT1R) which translates angiotensin stimulation into a (patho)physiological response. Recently, it was found that the A1166C polymorphism of the AT1R gene is associated with essential hypertension ${ }^{4}$ and myocardial infarction. ${ }^{5}$ The $\mathrm{C}$ allele of this polymorphism even shows a synergistical interaction with the $D$ allele of the angiotensin-converting enzyme (ACE) insertion/deletion polymorphism with respect to the risk of myocardial infarction. ${ }^{6}$ In addition, the $\mathrm{C}$ allele seems to be an independent determinant of aortic stiffness. ${ }^{7}$ Although these studies suggest that the $\mathrm{A} 1166 \mathrm{C}$ AT1R polymorphism contributes to cardiovascular disease, the exact role of this polymorphism in the pathophysiology of hypertension is as yet unclear. Moreover, no unequivocal data exist to show that this polymorphism may account for (part of) the variability in responsiveness to exogenous Angll, especially with regard to renal hemodynamics. Therefore, we conducted a study in which we investigated the possible influence of the A1166C polymorphism of the AT1R on the reactivity to Angll in hypertensive patients. To this end, we measured systemic and renal hemodynamic responses as well as humoral changes during infusion of graded doses of Angll. Studies were performed under conditions of high salt intake, since this augments the responsiveness to exogenous Angll.8,9 Since patients with the CC genotype run an increased risk of cardiovascular complications, we hypothesized that $\mathrm{C}$ allele carriers exhibit an increased responsiveness to Angll.

\section{Methods}

\section{Patients}

A genetic database of hypertensive patients was screened for those with the relatively rare CC genotype of the AT1R A1166C polymorphism. Eleven patients with this genotype were selected. Subsequently, the database was searched for patients with the AA and AC genotype to match with the selected CC patients for 
age, sex, and body mass index (BMI). Secondary hypertension was excluded on the basis of clinical and laboratory evalutation, as well as renal angiography if necessary. All 42 selected patients (14 AA, 17 AC, $11 \mathrm{CC}$ ) gave written informed consent to participate in the study. The study was approved by the Medical Ethics Committee of the University Hospital Maastricht.

\section{Genetic analysis}

DNA was extracted from whole blood with the use of the QIAamp" Blood Kit (Qiagen Inc., Valencia, CA, USA). We adopted the mutagenically separated PCR technique ${ }^{10}$ to determine the genotype of the AT1R A1166C mutation. Briefly, two allele-specific primers and their nonselective complementary strand primer were mixed and used for the PCR amplification in a single reaction. In addition to the base substitution, deliberate differences were introduced into the allele-specific primers. In that way we were able to drastically reduce cross-reactions between two allelic PCRs in a mixed reaction. The following primers were used:

- FP1166A, 5'-CTC TGC AGC ACT TCA CTA CCA AAT GAI CA-3'

- FP1166C, 5'-GAA GGA GCA AGA GAA CAT TCG CAA ATG AGA $\underline{C}-3^{\prime}$

- RP1166, 5'-TGC CGA CGA GCT TCT TGT TAC AGT CTT T-3'

(deliberated differences and base substitutions are underlined). The size of PCR products were $190 \mathrm{bp}$ and $210 \mathrm{bp}$ for the $1166 \mathrm{~A}$ and $1166 \mathrm{C}$ alleles, respectively. These products were resolved on a $3 \%$ agarose gel.

\section{Angll infusion protocol}

Patients were investigated after 7 days of high salt diet ( $220 \mathrm{mmol} \mathrm{Na} /$ day), with a fixed potassium intake of $80 \mathrm{mmol} /$ day. The rationale for a high salt intake is that under these circumstances, the endogenous Angll level is low, and therefore a response to exogenous Ang $\|$ is more pronounced and can be detected better than under low salt conditions." Compliance with the diet was checked by measuring sodium, potassium and creatinine output in 24 hour urine collections obtained during the last day of the dietary period. Antihypertensive medication had been stopped two weeks prior to the start of dietary intervention. Patients refrained from nicotine, alcohol, caffeine and caffeine-like substances from 8:00 PM the evening before the measurements. Experiments started at 8:30 AM after an overnight fast and patients remained supine during the entire session. In both arms an antecubital vein was cannulated with a $20 \mathrm{G}$ cannula. The cannula in the right arm was connected to a 3-way tap for the infusion of Angll and para- 
aminohippurate (PAH)/inulin (for measuring renal hemodynamics), whereas the cannula in the left arm was used for blood sampling. To ensure diuresis, subjects consumed $200 \mathrm{~mL}$ of water every hour until the last blood samples had been drawn. After a two-hour equilibration period, necessary to reach steady state plasma concentrations of $\mathrm{PAH}$ and inulin, stepwise increasing doses $(0.3,1.0$ and $3.0 \mathrm{ng} / \mathrm{kg} / \mathrm{min}$ ) of human Angll (Clinalpha AG, Laufelfingen, Switserland) were administered. Each infusion step was continued for 30 minutes to allow renal clearances to reach a new steady state. Blood pressure and heart rate (HR) were measured at a 3-minute time interval and after each infusion period blood samples were drawn for measurement of PAH, inulin, hematocrit and plasma levels of Angll, active plasma renin concentration (APRC), aldosterone and atrial natriuretic peptide (ANP). Blood samples for measurement of ACE were drawn only at baseline. All samples were stored at $-80^{\circ} \mathrm{C}$ until assay. For each determination, all samples from the same individual were assayed in a single run.

\section{Hemodynamic methods}

Systolic blood pressure (SBP) and diastolic blood pressure (DBP) and HR were measured by a semi-automatic oscillometric device (Dinamap Vital Signs Monitor 1846, Critikon, Tampa, FL, USA). Renal hemodynamics, i.e. effective renal plasma flow (ERPF) and glomerular filtration rate (GFR) were measured as the clearance of PAH (Merck Sharp \& Dohme, West Point, PA, USA) and inulin (Inutest, Laevosan Gesellschaft, Linz, Austria) respectively, using the continuous infusion method. ${ }^{12}$ Both variables were corrected for body surface area and expressed as $\mathrm{mL} / \mathrm{min} / 1.73 \mathrm{~m}^{2}$. Effective renal blood flow (ERBF) was calculated using the formula: ERPF/(1-hematocrit). Filtration fraction (FF) was calculated as GFR/ERPF. Renal vascular resistance (RVR) was calculated according to the formula: (mean blood pressure/ERBF) $\cdot 80,000$ and expressed in dynes $\cdot \mathrm{sec} \cdot \mathrm{cm}^{-5}$.

\section{Assay methods}

APRC was measured by a two-site direct immunoassay (Nichols Institute Diagnostics, San Juan Capistrano, CA, USA). ${ }^{13}$ For measuring Angll, blood samples were collected in tubes containing an inhibitor solution to prevent in vitro generation and degradation of this peptide, ${ }^{14}$ and spun immediately in a cooled centrifuge. Subsequently, the plasma was quickly frozen in liquid nitrogen. Hereafter, Angll was determined by ${ }^{125}$ I radioimmunoassay (RIA) following ethanol extraction (Nichols Institute Diagnostics, San Juan Capistrano, CA, USA). Aldosterone was assayed by means of a solid-phase protein binding RIA (Diagnostic Products Corporation, Los Angeles, CA, USA). ${ }^{15}$ ANP was measured by a 125 I RIA (DiaSorin Inc., Stillwater, MN, USA). ACE, PAH and inulin levels were measured by means of a spectrophotometer.12,16 Intra- and intercoefficients of 
variation of all assays were $<10 \%$. All samples from the same individual were assayed in a single run.

\section{Statistical analysis}

Sample size was estimated on the basis of the variability of the assay methods as derived from earlier studies. Of all measurements, assessment of ERPF has been shown to be the one with the highest standard deviation (in our hands $6.4 \%$ ). A difference in ERPF $>10 \%$ can be detected in this study with a power of 0.8 . Results are expressed as means \pm standard error of the mean (SEM). Because of small samples sizes $(n<20)$ non-parametric tests were used. To compare data between groups (AA, AC, and CC) a two step approach was used. First, overall differences between groups were evaluated by means of Kruskall-Wallis analysis of variance. When these analyses revealed a significant effect of genotype, data were further tested by pairwise comparisons using the Mann-Whitney $U$ test. To compare the effect of Angll infusion within groups, data were analysed by the Friedman test. Furthermore, results were analysed according to a recessive $C$ allele model (AA/AC patients versus CC patients) and to a dominant $C$ allele model (AA patients versus AC/CC patients). A P-value of less than 0.05 was considered to be statistically significant. Statistical analyses were performed using SPSS 11.0 for Windows (SPSS Inc., Chicago, IL, USA).

\section{Results}

\section{Baseline characteristics}

The baseline characteristics of the three genotype groups are summarized in Table 7.1. There were no significant differences in age, BMI, and 24 hour urinary sodium excretion $\left(U_{\mathrm{Na}} \mathrm{V}\right)$ between the groups. Systolic blood pressure (SBP) was higher in $A C$ patients compared to $A A$ patients $(P<0.05)$. HR was lower in $C C$ patients compared to AA patients $(P<0.05)$. GFR in CC patients was slightly lower compared to $A A$ patients $(P=0.06)$. Also, plasma aldosterone was lower in $C C$ patients both when compared to AA and when compared to AC patients $(P<0.05)$. Plasma ANP was significantly higher in CC patients compared to AA patients $(P<0.05)$. RVR, ERPF, ERBF, FF, APRC, Angll and ACE were comparable in the three groups. 
Table 7.1. Baseline characteristics.

\begin{tabular}{|c|c|c|c|}
\hline Parameter & AA & AC & CC \\
\hline Number (male/female) & $14(8 / 6)$ & $17(9 / 8)$ & $11(5 / 6)$ \\
\hline Age, years & $45 \pm 3$ & $49 \pm 3$ & $48 \pm 4$ \\
\hline $\mathrm{BML}, \mathrm{kg} / \mathrm{m}^{2}$ & $27.0 \pm 0.9$ & $26.7 \pm 1.1$ & $25.4 \pm 1.1$ \\
\hline SBP, $m m H g$ & $150 \pm 8$ & $172 \pm 7^{*}$ & $155 \pm 7$ \\
\hline $\mathrm{DBP}, \mathrm{mmHg}$ & $90 \pm 5$ & $94 \pm 4$ & $89 \pm 3$ \\
\hline Heart rate, beats/min & $68 \pm 3$ & $66 \pm 3$ & $60 \pm 3^{*}$ \\
\hline$U_{n a} V, m m o l / 24 h r$ & $214 \pm 22$ & $218 \pm 19$ & $236 \pm 26$ \\
\hline ERPF, $\mathrm{mL} / \mathrm{min} / 1.73 \mathrm{~m}^{2}$ & $415 \pm 23$ & $407 \pm 22$ & $391 \pm 36$ \\
\hline GFR, $\mathrm{mL} / \mathrm{min} / 1.73 \mathrm{~m}^{2}$ & $128 \pm 5$ & $125 \pm 6$ & $114 \pm 5$ \\
\hline FF & $0.32 \pm 0.01$ & $0.31 \pm 0.01$ & $0.31 \pm 0.02$ \\
\hline RVR, dynes-sec-cm ${ }^{s}$ & $13694 \pm 1258$ & $15272 \pm 1324$ & $14946 \pm 1369$ \\
\hline APRC, $m U / 2$ & $16.7 \pm 3.7$ & $10.9 \pm 1.2$ & $10.5 \pm 1.4$ \\
\hline Angll, pmol/2 & $16.3 \pm 2.7$ & $12.6 \pm 1.5$ & $14.2 \pm 3.0$ \\
\hline Aldosterone, $\mathrm{nmol} / \mathrm{L}$ & $0.25 \pm 0.06$ & $0.21 \pm 0.03$ & $0.11 \pm 0.02^{* 1}$ \\
\hline$A C E, U /$ & $17.2 \pm 1.2$ & $14.6 \pm 0.9$ & $17.0 \pm 1.2$ \\
\hline ANP, ng/L & $42.1 \pm 8.3$ & $58.6 \pm 7.4$ & $82.2 \pm 13.1^{* *}$ \\
\hline \multicolumn{4}{|c|}{$\begin{array}{l}\text { BML: body mass index; SBP: systolic blood pressure; DBP: diastolic blood pressure; Und: urinary } \\
\text { sodium excretion; ERPF: effective renal plasma flow; ERBF: effective renal blood flow; GFR: glomerular } \\
\text { filtration rate; FF: filtration fraction; RVR: renal vascular resistance; APRC: active plasma renin } \\
\text { concentration; Angll: angiotensin II; ACE: angiotensin-converting enzyme; ANP: atrial natriuretic } \\
\text { peptide; }{ }^{*} P<0.05 \text { vs. AA; }{ }^{+P}<0.05 \text { vs. AC. }\end{array}$} \\
\hline
\end{tabular}

\section{Responses to Angll}

Plasma Angll levels were comparable for all genotype groups during the different infusion doses of Angll. A significant increase during Angll infusion within all groups was found for SBP, diastolic blood pressure (DBP), RVR, Angll, aldosterone, and ANP, whereas a significant decrease during Angll infusion within all groups was found for ERPF, ERBF, and APRC. No differences were found between the genotype groups for both SBP and DBP at any dose of Angll. During infusion of all doses of Angll, HR showed a decrease in CC patients, while it did not change in AA and $A C$ patients (Figure 7.1). (Borderline) significant differences in $\mathrm{HR}$ were found between $A C$ and CC patients at 0.3 and $1.0 \mathrm{ng} / \mathrm{kg} / \mathrm{min}$, and between AA and CC at 0.3 and $3.0 \mathrm{ng} / \mathrm{kg} / \mathrm{min}$. At the lowest dose of Angll, GFR showed a small increase in AA patients, in contrast to a small decrease in CC patients $(P<0.05$; Figure 7.2). No differences between the genotype groups were found at the higher doses. ERPF in AA and AC patients did not change at the lowest dose, whereas CC patients showed a marked decrease which was significantly different from the response in AA patients $(P<0.05$; Figure 7.3$)$. No differences between the genotype groups were found at the higher doses. The increase in RVR during the lowest dose was more pronounced also in CC patients compared to AA patients, although not significantly ( $P=0.07$; Figure 7.4 ). Again no differences between the genotype groups were found at the higher doses. There were no differences between the 
genotype groups with respect to changes in FF, APRC, aldosterone, and ANP during the three doses of Angll.

\section{Genetic model}

Comparing a recessive $C$ allele model (AA/AC patients versus $C C$ patients) with a dominant $C$ allele model (AA patients versus $A C / C C$ patients) showed that the differences as described above remained only significant in the recessive model.

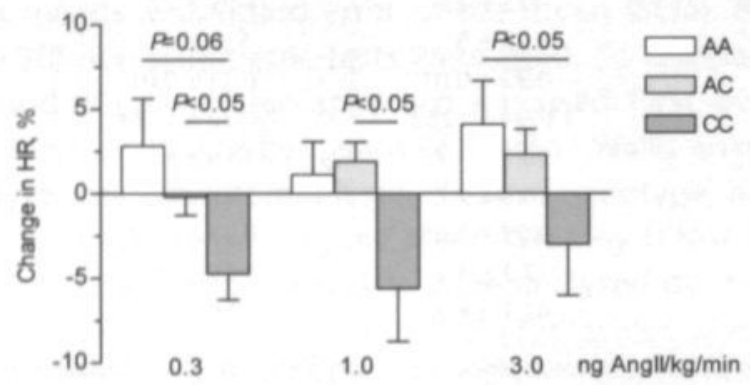

Figure 7.1. Responses of HR to increasing doses of continuously infused Angll.

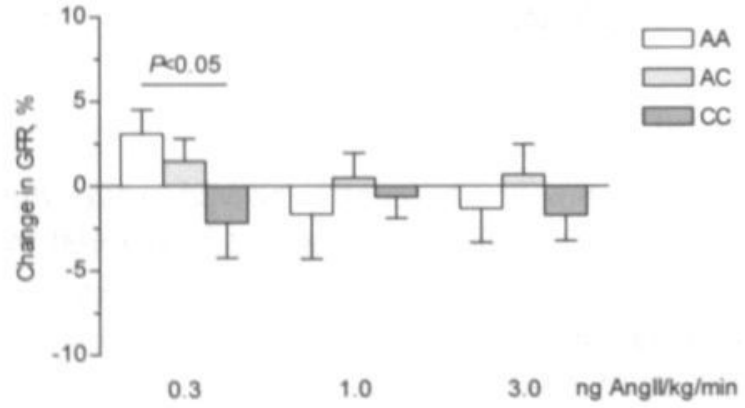

Figure 7.2. Responses of GFR to increasing doses of continuously infused Angll.

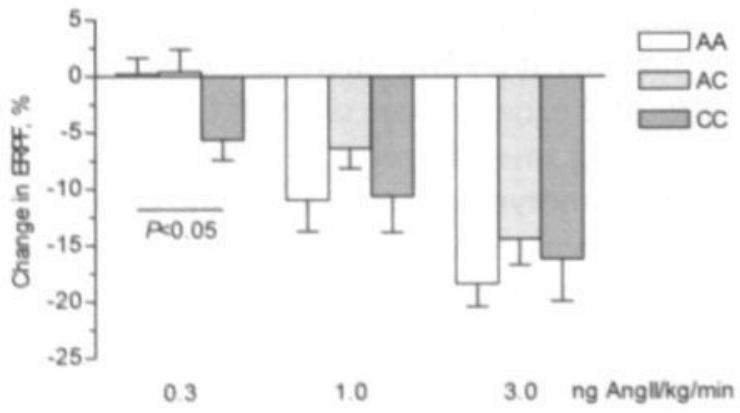

Figure 7.3. Responses of ERPF to increasing doses of continuously infused Angll. 


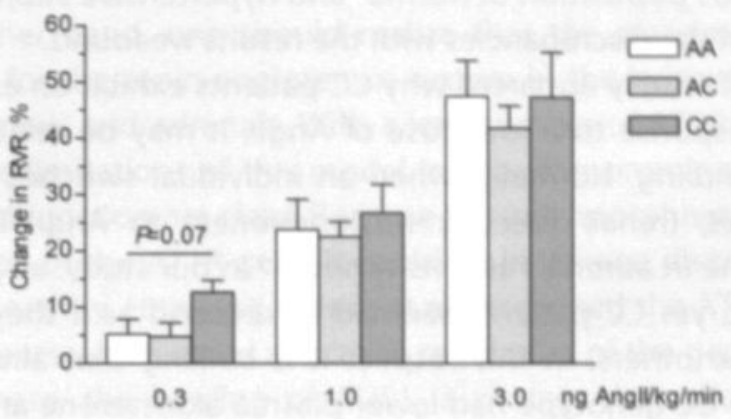

Figure 7.4. Responses of RVR to increasing doses of continuously infused Angll.

\section{Discussion}

This study investigated the potential role of the AT1R A1166C polymorphism in the renal hemodynamic and humoral responses to Angll in essential hypertensive patients during high sodium diet. Our data show that patients with the CC genotype display an exaggerated response of GFR, ERPF and RVR to Angll at a low dose of $0.3 \mathrm{ng} / \mathrm{kg} / \mathrm{min}$, but not at the higher doses employed. In addition, we found that CC patients, in contrast to the others, respond to Angll with an overall decrease in HR. Thus, except for the changes in HR, phenotypic differences between the groups were observed only at the lowest dose when plasma levels of Angll remain within the physiological range. Because responses to Angll during the supraphysiological doses of 1.0 and $3.0 \mathrm{ng} / \mathrm{kg} / \mathrm{min}$ were comparable between the genotype groups, our data indicate that sensitivity, but not reactivity to Angll is increased in CC patients. These findings are in line with observations by others showing increased vascular responsiveness of coronary and internal mammarian arteries, to different stimuli in patients carrying the $C$ allele. ${ }^{17,18}$

We did not find any differences between the genotype groups with respect to their humoral responses to Angll. This is in agreement with the data of Giacche et al. who measured the aldosterone response to Angll in Caucasian hypertensives after a low salt diet and found no differences between the genotype groups. ${ }^{19}$ Unfortunately, they only infused $3.0 \mathrm{ng} / \mathrm{kg} / \mathrm{min}$ and they $\mathrm{did}$ not study their patients after a high salt diet, when the effects of exogenous Angll are likely to be more pronounced.8,9

Recently, after we had completed our investigation, a study like ours was published in which no differences in response to Angll between the 3 genotypes were found. ${ }^{20}$ However, the authors of that study used a higher initial dose of Angll: $0.5 \mathrm{ng} / \mathrm{kg} / \mathrm{min}$. This dose may already be too high to find the increased sensitivity to Angll. Furthermore, the data they presented were based on 15 min infusions, which could be too short to attain a steady state effect of Angll. Finally, 
the heterogeneous population of normo- and hypertensive subjects in that study could also explain the discrepancies with the results we found.

Although it is not readily apparent why CC patients exhibit an exaggerated renal hemodynamic response to a low dose of Angll, it may be related to an altered renal sodium handling. Normally, when an individual switches from a low to a high sodium diet, (renal) vascular responsiveness to Angll increases with a concurrent decline in adrenal responsiveness. ${ }^{8,9}$ In our study, all patients adhered to the same diet, yet CC patients seemed to respond as if they were more salt repleted than the others. In this respect it is striking that already at baseline, patients with the $\mathrm{CC}$ genotype had lower plasma aldosterone and higher plasma ANP levels as compared to the AA genotype. Although we did not measure body fluid volumes, the latter combination strongly suggests that, at least after one week of high sodium intake, CC patients are relatively hypervolemic. Since we did not study our patients at low salt intake, we do not know whether this relative hypervolemia is an intrinsic abnormality of CC patients or that it becomes evident only at a high salt intake. Whatever the case may be, we can only speculate why CC patients apparently fail to adjust their (circulating) volume in response to a high salt diet. As tubular reabsorption of sodium is partly regulated by Angll, it is possible that the responses of renal tubular cells to Angll are enhanced as well in patients with the CC genotype. Indeed, the fact that CC patients had comparable Angll levels as the other genotype groups, but tended to have a lower GFR and ERPF and a higher RVR even before the Angll infusion was started, suggests that these patients may also be hyperresponsive to endogenous Angll.

A remarkable finding in our data concerns HR which not only was significantly lower in CC patients as compared to AA patients before the infusion, but also slowed down at all levels of Angll infusion in CC patients while it did not change appreciably in the others. All these differences occurred in the face of comparable blood pressures. Therefore, it seems as if baroreceptor sensitivity is enhanced in CC patients which would be in line with our 'hypervolemia hypothesis'. Indeed, if we assume that circulating volume is increased in CC patients, then a baroreceptor-mediated decline in HR would be one mechanism to prevent too much of a rise in blood pressure.

Although several of our data suggest an 'allele dose effect', further analysis in which combinations of genotypes were compared (AA versus $A C / C C$ and $A A / A C$ versus $(C)$, points towards a recessive effect of the $C$ allele. This indicates that it is highly probable that the significant results found in CC patients have to be explained by the genotype of the AT1R A1166C polymorphism rather than by chance.

It remains elusive, why the $C$ allele of the AT1R A1166C polymorphism is associated with increased sensitivity to Angll and, in the end, an increased incidence of cardiovascular disease. ${ }^{47,21-27}$ As we ${ }^{28}$ and others ${ }^{29}$ did not find differences in the number of platelet AT1R binding sites $\left(B_{\max }\right)$ and Angll affinity 
$\left(K_{0}\right)$, differences probably cannot be explained by the number and function of the AT1R. On the other hand, one should realize that the platelet model is just a surrogate model for the renin-angiotensin system in the systemic circulation, as well as in the kidneys and adrenals. With a low number of AT1Rs ${ }^{29-31}$ per platelet (about 4 to 6) the limitations of this model in showing prominent differences in AT1R number and function are clear. Because this polymorphism is located in the uncoding $3^{\prime}$-region of the AT1R gene it could be in linkage disequilibrium with a coding mutation nearby. However, Poirier et al. rescanned the AT1R gene, but did not find new variants which could affect the regulation of the gene in response to Angll. ${ }^{32}$ Furthermore, the binding of AUF1, a protein that affects ATIR mRNA stability through binding to AU-rich regions of the uncoding 3 '-untranslated region of the mRNA, is not affected by this polymorphism..$^{33}$

In conclusion, we have found that the genotype of the AT1R A1166C polymorphism is yet another factor that needs to be taken into account when assessing the effects of Angll on the kidney. Increased sensitivity to Angll may well be associated with a tendency for volume expansion and hence volumedependent hypertension. 


\section{References}

1. Shoback DM, Williams GH, Moore TJ, Dluhy RG, Podolsky S, Hollenberg NK. Defect in the sodiummodulated tissue responsiveness to angiotensin II in essential hypertension. J Clin Invest 1983;72:2115-24.

2. de Leeuw PW, van Es PN, Looman M, Birkenhager WH. Renal response to converting enzyme blockade. J Hypertens 1985;3 Suppl 3:S295-6.

3. Krekels MM, Spiering W, Schaper NC, Houben AJ, de Leeuw PW. Dissociation between the renal effects of angiotensin I and II in sodium-restricted normal subjects. Cardiovasc Res 1998;38: 215-20.

4. Bonnardeaux A, Davies E, Jeunemaitre X, Fery I, Charru A, Clauser E, Tiret L, Cambien F, Corvol P, Soubrier F. Angiotensin II type 1 receptor gene polymorphisms in human essential hypertension. Hypertension 1994:24:63-9.

5. Berge KE, Bakken A, Bohn M, Erikssen J, Berg K. A DNA polymorphism at the angiotensin II type 1 receptor (AT1R) locus and myocardial infarction. Clin Genet 1997;52:71-6.

6. Tiret L, Bonnardeaux A, Poirier O, Ricard S, Marques-Vidal P, Evans A, Arveiler D, Luc G, Kee F, Ducimetiere $P$, et al. Synergistic effects of angiotensin-converting enzyme and angiotensin-II type 1 receptor gene polymorphisms on risk of myocardial infarction. Lancet 1994;344:910-3.

7. Benetos A, Topouchian J, Ricard S, Gautier S, Bonnardeaux A, Asmar R, Poirier O, Soubrier F, Safar $\mathrm{M}$, Cambien $\mathrm{F}$. Influence of angiotensin II type 1 receptor polymorphism on aortic stiffness in never-treated hypertensive patients. Hypertension 1995;26:44-7.

8. Oelkers W, Brown JJ, Fraser R, Lever AF, Morton JJ, Robertson JI. Sensitization of the adrenal cortex to angiotensin II in sodium-deplete man. Circ Res 1974;40:69-77.

9. Hollenberg NK, Chenitz WR, Adams DF, Williams GH. Reciprocal influence of salt intake on adrenal glomerulosa and renal vascular responses to angiotensin II in normal man. J Clin Invest 1974:54:34-42.

10. Rust S, Funke $H$, Assmann G. Mutagenically separated PCR (MS-PCR): a highly specific one step procedure for easy mutation detection. Nucleic Acids Res 1993;21:3623-9.

11. Thurston $\mathrm{H}$, Laragh JH. Prior receptor occupancy as a determinant of the pressor activity of infused angiotensin II in the rat. Circ Res 1975;36:113-7.

12. Cole BR, Giangiacomo J, Ingelfinger JR, Robson AM. Measurement of renal function without urine collection. A critical evaluation of the constant-infusion technic for determination of inulin and para-aminohippurate. NEngl J Med 1972;287:1109-14.

13. Simon D, Hartmann DJ, Badouaille G, Caillot G, Guyenne TT, Corvol P, Pau B, Marchand J. Two-site direct immunoassay specific for active renin. Clin Chem 1992;38:1959-62.

14. Nussberger J, Brunner DB, Waeber B, Brunner HR. True versus immunoreactive angiotensin II in human plasma. Hypertension 1985;7:11-7.

15. Kubasik NP, Warren K, Sine HE. Evaluation of a new commercial radioassay kit for aldosterone using an iodinated tracer. Clin Biochem 1979;12:59-61.

16. Brun C. A rapid method for the determination of para-aminohippuric acid in kidney function tests. J Lab Clin Med 1951:37:955-8.

17. Amant C, Hamon M, Bauters C, Richard F, Helbecque N, McFadden EP, Escudero X, Lablanche JM, Amouyel P, Bertrand ME. The angiotensin II type 1 receptor gene polymorphism is associated with coronary artery vasoconstriction. J Am Coll Cardiol 1997;29:486-90.

18. Henrion D, Amant C, Benessiano J, Philip I, Plantefeve G, Chatel D, Hwas U, Desmont JM, Durand G, Amouyel P, Levy BI. Angiotensin II type 1 receptor gene polymorphism is associated with an increased vascular reactivity in the human mammary artery in vitro. J Vasc Res 1998;35:356-62.

19. Giacche M, Vuagnat A. Williams GH, Corvol P, Jeunemaitre X, Pascoe L. The type 1 angiotensin II receptor gene (ATIR) is not involved in the genetic variability of aldosterone response to All infusion (abstract). Am J Hypertens 1998;11:42A. 
20. Hilgers KF, Langenfeld MR, Schlaich M, Veelken R. Schmieder RE. 1166 AVC polymorphism of the angiotensin II type 1 receptor gene and the response to short-term infusion of angiotensin II. Circulation 1999;100:1394-9.

21. Hingorani AD, Jia H, Stevens PA, Hopper R, Dickerson JE, Brown MJ. Renin-angiotensin system gene polymorphisms influence blood pressure and the response to angiotensin converting enzyme inhibition. J Hypertens 1995;13:1602-9.

22. Nakauchi $Y$, Suehiro T, Yamamoto $M$, Yasuoka N, Arii $K$, Kumon $Y$, Hamashige N, Hashimoto $K$. Significance of angiotensin I-converting enzyme and angiotensin II type 1 receptor gene polymorphisms as risk factors for coronary heart disease. Atherosclerosis 1996;125:161-9.

23. Doria A, Onuma T, Warram JH, Krolewski AS. Synergistic effect of angiotensin II type 1 receptor genotype and poor glycaemic control on risk of nephropathy in IDDM. Diabetologia 1997:40:1293-9.

24. Wang WY, Zee RY, Morris BJ. Association of angiotensin II type 1 receptor gene polymorphism with essential hypertension. Clin Genet 1997;51:31-4.

25. Osterop AP, Kofflard MJ, SandkuijI LA, ten Cate FJ, Krams R, Schalekamp MA, Danser AH. ATI receptor A/C1166 polymorphism contributes to cardiac hypertrophy in subjects with hypertrophic cardiomyopathy. Hypertension 1998;32:825-30.

26. Szombathy T, Szalai C, Katalin B, Palicz T, Romics L, Csaszar A. Association of angiotensin II type 1 receptor polymorphism with resistant essential hypertension. Clin Chim Acta 1998;269:91-100.

27. Kainulainen $\mathrm{K}$, Perola M, Terwilliger J, Kaprio J, Koskenvuo M, Syvanen AC, Vartiainen E, Peltonen L. Kontula K. Evidence for involvement of the type 1 angiotensin II receptor locus in essential hypertension. Hypertension 1999;33:844-9.

28. Spiering W, Kroon AA, Fuss-Lejeune MJ, de Leeuw PW. Genetic contribution to the acute effects of angiotensin II type 1 receptor blockade. Submitted 2003.

29. Paillard F, Chansel D, Brand E, Benetos A, Thomas F, Czekalski S, Ardaillou R, Soubrier F. Genotype-phenotype relationships for the renin-angiotensin-aldosterone system in a normal population. Hypertension 1999;34:423-9.

30. Makarious M, Pawlak M, Campbell LV, Timmermans V, Duggan K, Charlesworth JA, Macdonald GJ. The platelet angiotensin II receptor in type I diabetes: studies in patients with and without nephropathy. Eur J Clin Invest 1993;23:517-21.

31. Mann JF, Sis J, Ritz E. 125I-Angiotensin II binding to human blood cells. J Hypertens 1985;3:131-7.

32. Poirier O, Georges JL, Ricard S, Arveiler D, Ruidavets JB, Luc G, Evans A, Cambien F, Tiret L. New polymorphisms of the angiotensin II type 1 receptor gene and their associations with myocardial infarction and blood pressure: the ECTIM study. Etude Cas-Temoin de l'Infarctus du Myocarde. J Hypertens 1998;16:1443-7.

33. Pende A, Giacche M, Castigliola L, Contini L, Passerone G, Patrone M, Port JD, Lotti G. Characterization of the binding of the RNA-binding protein AUF1 to the human AT(1) receptor mRNA. Biochem Biophys Res Commun 1999;266:609-14. 


\section{Chapter 8}

\section{Genetic contribution to the acute effects of angiotensin II type 1 receptor blockade}

Wilko Spiering, Abraham A. Kroon, Monique J. Fuss-Lejeune, Paul M. Schiffers, Peter W. de Leeuw 


\section{Abstract}

\section{Background}

Clinical observations point towards heterogeneity in patients' responses to antihypertensive drugs. In all likelihood, this is at least in part genetically determined. As our earlier work showed that angiotensin II (AngII) sensitivity is associated with the A1166C polymorphism of the Angll type 1 receptor (AT1R) gene, we conducted the present study in which the responses to acute AT1R blockade were studied.

\section{Methods}

After both 7 days of low ( $55 \mathrm{mmol} \mathrm{Na} /$ day) and high ( $220 \mathrm{mmol} \mathrm{Na} /$ day) sodium diet, the systemic and renal hemodynamic as well as humoral effects of acute AT1R blockade with EXP3174 (active metabolite of losartan) were studied in 29 essential hypertensive patients genotyped for the AT1R A1166C polymorphism (15 AA and $14 \mathrm{CC}$ ). By means of plateletbinding studies the baseline $A T 1 R$ density $\left(B_{\max }\right)$ and affinity $\left(K_{D}\right)$ was tested.

\section{Results}

During low and high salt diet, baseline $B_{\max }$ and $K_{D}$ were comparable between both genotype groups. At baseline, during low salt diet, CC patients had significantly lower glomerular filtration rate and nearly significantly lower effective renal plasma flow (ERPF) compared to AA patients. Blood pressure responses to EXP3174 during high salt were significantly blunted in CC patients compared to AA patients (mean arterial pressure: $1.8 \%$ vs. $7.5 \%)$. During low salt the increase in ERPF (12.9\% vs. $16.1 \%)$, as well as the decrease in filtration fraction $(9.0 \%$ vs. $14.0 \%)$ and renal vascular resistance $(7.5 \%$ vs. $15.1 \%)$ were blunted in CC patients compared to AA patients. Humoral effects were not different between the groups.

\section{Conclusion}

This study shows that the systemic and renal hemodynamic responses to acute AT1R blockade are at least in part genetically determined. 


\section{Introduction}

One of the striking features of essential hypertension is the heterogeneity of patients' responses to antihypertensive drugs. Recent data indicate that this is, at least partly, genetically determined and that genetic polymorphisms in effector systems may predict the responsiveness to pharmacological agents. ${ }^{1,2}$ An outstanding example where this supposition could be tested is the interaction between the polymorphisms of the angiotensin II (Angll) type 1 receptor (AT1R) and the response to AT1R blockade. The gene coding for the ATIR has a polymorphism (A1166C) in the 3'-untranslated region, which was found to be associated with myocardial infarction, ${ }^{3}$ hypertension, ${ }^{4.5}$ pregnancy-induced hypertension, ${ }^{6}$ lacunar infarction, ${ }^{7}$ and faster deterioration of renal function. ${ }^{8}$ We recently found that Angll sensitivity is also associated with this polymorphism, ${ }^{9}$ with $C$ allele carriers showing an increased renovascular sensitivity to Angll. Whether responsiveness to AT1R blockade is also different in relation to this polymorphism is not well known. In one study, Miller et al. found blunted humoral and renal hemodynamic responses in AA subjects compared to $A C / C C$ subjects after a single oral dose of losartan. ${ }^{10}$ However, since the acute effects of AT1R blockade were not assessed by intravenous administration of the antagonist, differences in biological availability could have contributed at least partially to the variation in response. Moreover, only 7 CC subjects were studied who were pooled with the AC patients for analysis. This prompted us to conduct a study on the systemic and renal hemodynamic as well as humoral effects of intravenously infused EXP3174 (the active metabolite of losartan) in hypertensive subjects with either the AA or the CC genotype. By selecting patients who were homozygous for either the wild type or the mutant receptor gene, we aimed to maximize the contrast between groups. For this reason, we also refrained from including a heterozygous group of patients. Based on our earlier finding of increased Angll sensitivity in CC subjects, we anticipated that $C$ allele carriers would exhibit a potentiated response as compared to AA patients.

\section{Methods}

\section{Patients}

A genetic database of hypertensive patients from the Hypertension Research Unit of the University Hospital Maastricht was screened for those genotyped for the AT1R A1166C polymorphism. Patients entered the study if they fulfilled all the inclusion criteria: age between 18 and 80 years, Caucasian, hypertension according to World Health Organization-International Society of Hypertension 
criteria"1, able to stop antihypertensive medication for 4 weeks. Exclusion criteria were secondary hypertension, congestive heart failure (New York Heart Association classes II through IV), hepatic ( $\geq$ Child-Pugh B) or renal insufficiency (creatinine clearance $<60 \mathrm{~mL} / \mathrm{min}$ ). Detailed evaluation of hormones and endocrine metabolites was conducted if indicated. In case of clinical suspicion of a renal artery stenosis, renal angiography was performed. Twenty-nine hypertensive patients (15 AA and $14 \mathrm{CC}$ ) were selected matched for age, sex and body mass index (BMI). All selected patients gave written informed consent to participate in the study. The study was approved by the Medical Ethics Committee of the University Hospital Maastricht.

\section{Genetic analysis}

DNA was extracted from whole blood with the use of the QIAamp" Blood Kit (Qiagen Inc., Valencia, CA, USA). The AT1R A1166C polymorphism was genotyped with means of mutagenically separated PCR, as described earlier. ${ }^{9}$

\section{EXP3174 infusion protocol}

All patients started with a low salt diet ( $55 \mathrm{mmol} \mathrm{Na}^{+} /$day), subsequently followed by a high salt diet $(220 \mathrm{mmol} \mathrm{Na} /$ day), both with a fixed potassium intake of 80 $\mathrm{mmol} /$ day. Compliance with the diets was checked by measuring sodium, potassium and creatinine output in two 24 hour urine collections obtained during the last 2 days of the dietary period. Infusion experiments took place on the last day of each salt diet. Antihypertensive medication had been stopped two weeks prior to the start of the low salt diet and was continued during both salt diets. Patients refrained from nicotine, alcohol, caffeine and caffeine-like substances from 8:00 PM the evening before the measurements. Experiments started at 8:30 AM after an overnight fast and patients remained supine during the entire session. In both arms an antecubital vein was cannulated with a $20 \mathrm{G}$ cannula. The cannula in the right arm was connected to a 3-way tap for the infusion of EXP3174 and para-aminohippurate (PAH)/inulin (for measuring renal hemodynamics), whereas the cannula in the left arm was used for blood sampling. To ensure diuresis, subjects consumed $200 \mathrm{~mL}$ of water every hour until the last blood samples had been drawn. After a two-hour equilibration period, necessary to reach steady state plasma concentrations of PAH and inulin, stepwise increasing doses (1.0, 3.0 and $10.0 \mu \mathrm{g} / \mathrm{kg} / \mathrm{min}$ ) of EXP3174 (active metabolite of losartan; generous gift of Merck Sharp \& Dohme, West Point, PA, USA) were administered. Each infusion step was continued for 30 minutes to allow renal clearances to reach a new steady state. Blood pressure and heart rate (HR) were measured at a 3-minute time interval and after each infusion period blood samples were drawn for measurement of PAH, inulin, hematocrit and plasma levels of Angll, active plasma renin concentration (APRC) and aldosterone. Blood samples for measurement of angiotensin- 
converting enzyme (ACE) were drawn only at baseline. All samples were stored at $80^{\circ} \mathrm{C}$ until assay.

\section{Hemodynamic methods}

Systolic blood pressure (SBP), diastolic blood pressure (DBP), mean blood pressure (MBP) and HR were measured by a semi-automatic oscillometric device (Dinamap Vital Signs Monitor 1846, Critikon, Tampa, FL, USA). Pulse pressure (PP) was calculated as the difference between SBP and DBP. Renal hemodynamics, i.e. effective renal plasma flow (ERPF) and glomerular filtration rate (GFR) were measured as the clearance of PAH (Merck Sharp \& Dohme, West Point, PA, USA) and inulin (Inutest, Laevosan Gesellschaft, Linz, Austria) respectively, using the continuous infusion method. ${ }^{12}$ Both variables were corrected for body surface area and expressed as $\mathrm{mL} / \mathrm{min} / 1.73 \mathrm{~m}^{2}$. Effective renal blood flow (ERBF) was calculated using the formula: ERPF/(1-hematocrit). Filtration fraction (FF) was calculated as GFR/ERPF. Renal vascular resistance (RVR) was calculated according to the formula: (MBP/ERBF) 80,000 and expressed in dynes. $\mathrm{sec} \cdot \mathrm{cm}^{-5}$.

\section{Assay methods}

Active plasma renin concentration (APRC) was measured by a two-site direct immunoassay (Nichols Institute Diagnostics, San Juan Capistrano, CA, USA). ${ }^{13}$ For measuring Angll, blood samples were collected in tubes containing an inhibitor solution to prevent in vitro generation and degradation of this peptide, ${ }^{14}$ and spun immediately in a cooled centrifuge. Subsequently, the plasma was quickly frozen in liquid nitrogen. Hereafter, Angll was determined by ${ }^{125} 1$ radioimmunoassay (RIA) following extraction from plasma. Aldosterone was assayed by means of a solidphase protein binding RIA (Diagnostic Products Corporation, Los Angeles, CA, USA). ${ }^{15}$ ACE, PAH and inulin levels were measured spectrophotometrically. ${ }^{12,16}$ Intra- and interassaycoefficients of variation of all assays were $<10 \%$. All samples from the same individual were assayed in a single run.

\section{Platelet-binding studies}

Platelet-rich plasma was obtained from $20 \mathrm{~mL}$ of venous blood (collected in a sodiumcitrate containing glass tube) by centrifugation at $100 \mathrm{~g}$ for 15 minutes at room temperature. It was then washed with 20 volumes of cold Tris-buffered saline (Tris- $\mathrm{HCl} 50 \mathrm{mmol} / \mathrm{L}, \mathrm{NaCl} 100 \mathrm{mmol} / \mathrm{L}, \mathrm{Na}_{2}$ EDTA 5 mmol/L, 0.05\% BSA, pH 7.4) and centrifuged at $1000 \mathrm{~g}$ for 15 minutes at $4^{\circ} \mathrm{C}$. After repeating washings and centrifugations once more, platelets were resuspended in assay buffer. The suspension platelet number was determined automatically in a Coulter counter and the volume was adjusted to give a final platelet number of $10 \% / \mu \mathrm{L}$. Incubations were performed in a total volume of $250 \mu \mathrm{L}$ that included $100 \mu \mathrm{L}$ of 
platelet suspension. Saturation equilibrium binding studies were performed in the presence of increasing concentrations of 125 -labeled Angll $(0.040-1.000 \mathrm{nmol} / \mathrm{L}$; Amersham, Buckinghamshire, UK). Nonspecific binding was ascertained in the presence of $10 \mu \mathrm{mol} / \mathrm{L}$ of unlabeled Angll. Incubation was performed for 90 minutes at $25^{\circ} \mathrm{C}$ in a shaking warm water bath. At the end of the incubation period, $4 \mathrm{~mL}$ of ice-cold assay buffer was added to each tube and the platelets were separated from the buffer by vacuum-filtration over GF/C Whatman filters (Whatman, Maidstone, UK). Radioactivity of the GF/C filter was measured in a LKBWallac gamma counter. The results of the saturation binding assays were analyzed by Scatchard transformation of the data to calculate the $K_{\mathrm{D}}$ and the number of sites $B_{\max }$.

\section{Statistical analysis}

Sample size was estimated on the basis of the variability of the assay methods as derived from earlier studies. Of all measurements, assessment of ERPF has been shown to be the one with the highest standard deviation (in our hands $6.4 \%$ ). A difference in ERPF $>13 \%$ can be detected in this study with a power of 0.8 . Results are expressed as means \pm standard error of the mean (SEM). To avoid the problem of repeated measures, we used maximum responses (increase or decrease) during EXP3174 infusion of each patient for statistical analysis. Because of small sample sizes $(n<20)$ non-parametric tests were used. A P-value of less than 0.05 was considered to be statistically significant. Statistical analyses were performed using SPSS 11.0 for Windows (SPSS Inc., Chicago, IL, USA).

\section{Results}

\section{Baseline characteristics}

Baseline characteristics of the two genotype groups are summarized in Tables 8.1-3. There were no significant differences in gender, age, body mass index (BMI) and serum ACE concentration. During low salt diet CC patients showed a lower GFR $(P<0.05)$ and slightly lower ERPF $(P=0.08)$ compared to AA patients. Although compliance with the diet was not optimal, the expected shift in sodium excretion when going from the low to the high salt diet was found in each patient. The number of platelet $A T 1 R$ binding sites $\left(B_{\max }\right)$ and Angll affinity $\left(K_{D}\right)$ were comparable for both genotype groups during both low and high salt. 
Table 8.1. Baseline characteristics.

\begin{tabular}{|c|c|c|}
\hline Variable & AA & $\mathrm{CC}$ \\
\hline Number (male/female) & $15(8 / 7)$ & $14(8 / 6)$ \\
\hline Age, years & $52 \pm 3$ & $55 \pm 2$ \\
\hline BMl, $\mathrm{kg} / \mathrm{m}^{2}$ & $27.2 \pm 1.2$ & $28.5 \pm 1.3$ \\
\hline ACE, U/L & $15 \pm 1$ & $15 \pm 2$ \\
\hline
\end{tabular}

Table 8.2. Baseline systemic, renal hemodynamic and humoral characteristics during low salt.

\begin{tabular}{|c|c|c|}
\hline Variable & AA & $\mathrm{CC}$ \\
\hline $\mathrm{U}_{\mathrm{Na}} \mathrm{V}, \mathrm{mmol} / 24 \mathrm{hr}$ & $83 \pm 12$ & $81 \pm 13$ \\
\hline $\mathrm{MBP}, \mathrm{mmHg}$ & $124 \pm 4$ & $122 \pm 5$ \\
\hline ERPF, $m L / m i n / 1.73 m^{2}$ & $373 \pm 24$ & $307 \pm 27$ \\
\hline $\mathrm{GFR}, \mathrm{mL} / \mathrm{min} / 1.73 \mathrm{~m}^{2}$ & $114 \pm 7$ & $94 \pm 5^{*}$ \\
\hline FF & $0.31 \pm 0.02$ & $0.33 \pm 0.02$ \\
\hline RVR, dynes-sec. $\mathrm{cm}^{-5}$ & $16400 \pm 1267$ & $17756 \pm 1741$ \\
\hline $\mathrm{APRC}, m U / L$ & $14.7 \pm 2.3$ & $15.8 \pm 2.3$ \\
\hline Angll, pmol/L & $8.4 \pm 2.1$ & $6.5 \pm 0.9$ \\
\hline Aldosterone, $\mathrm{nmol} / \mathrm{L}$ & $0.21 \pm 0.03$ & $0.26 \pm 0.03$ \\
\hline B $\max$ fmol/10 platelets & $5.86 \pm 1.36$ & $4.27 \pm 0.57$ \\
\hline$K_{\mathrm{D}}, \mathrm{pmol} / \mathrm{L}$ & $672.0 \pm 211.5$ & $615.9 \pm 172.7$ \\
\hline
\end{tabular}

Table 8.3. Baseline systemic, renal hemodynamic and humoral characteristics during high salt.

\begin{tabular}{|c|c|c|}
\hline Variable & AA & CC \\
\hline $\mathrm{U}_{\mathrm{NaV}}, \mathrm{mmol} / 24 \mathrm{hr}$ & $147 \pm 14$ & $172 \pm 15$ \\
\hline $\mathrm{MBP}, \mathrm{mmHg}$ & $129 \pm 5$ & $120 \pm 3$ \\
\hline ERPF, $\mathrm{mL} / \mathrm{min} / 1.73 \mathrm{~m}^{2}$ & $370 \pm 33$ & $299 \pm 25$ \\
\hline GFR, $\mathrm{mL} / \mathrm{min} / 1.73 \mathrm{~m}^{2}$ & $114 \pm 7$ & $98 \pm 7$ \\
\hline FF & $0.33 \pm 0.02$ & $0.34 \pm 0.02$ \\
\hline RVR, dynes $\cdot \mathrm{sec} \cdot \mathrm{cm}^{-5}$ & $17810 \pm 2138$ & $17901 \pm 1392$ \\
\hline $\mathrm{APRC}, m U / L$ & $12.7 \pm 2.3$ & $12.0 \pm 1.7$ \\
\hline Angll, pmol/L & $5.2 \pm 1.2$ & $5.6 \pm 1.1$ \\
\hline Aldosterone, $\mathrm{nmol} / \mathrm{L}$ & $0.19 \pm 0.04$ & $0.19 \pm 0.03$ \\
\hline $\mathrm{B}_{\max }, \mathrm{fmol} / 10^{9}$ platelets & $6.40 \pm 1.25$ & $5.67 \pm 1.48$ \\
\hline$K_{\mathrm{D}}, \mathrm{pmol} / \mathrm{L}$ & $632.0 \pm 231.6$ & $565.6 \pm 147.5$ \\
\hline
\end{tabular}

$\mathrm{U}_{\mathrm{Na}} \mathrm{V}$ : urinary sodium excretion; MBP: mean blood pressure; ERPF: effective renal plasma flow; GFR: glomerular filtration rate; FF: filtration fraction; RVR: renal vascular resistance; APRC: active plasma renin concentration; Angll: angiotensin II; $B_{\max }$ maximum number of specific binding sites; $K_{\mathrm{D}}$ : equilibrium dissociation constant. 


\section{Low salt}

There were no significant differences in responses for SBP (Figure 8.1), DBP (Figure 8.2), MBP and PP between the groups. CC patients showed a small, but significant increase $(5 \mathrm{bpm}(7.9 \%))$ in $\mathrm{HR}(P<0.05$ vs. AA response; Figure 8.3$)$. The absolute increase in ERPF was $61 \mathrm{~mL} / \mathrm{min} / 1.73 \mathrm{~m}^{2}$ in AA subjects, compared to only 29 $\mathrm{mL} / \mathrm{min} / 1.73 \mathrm{~m}^{2}$ in CC patients $(P<0.01)$. After correcting for the lower ERPF at baseline in CC patients, the blunted increase in ERPF in these patients was $12.9 \%$ compared to $16.1 \%$ in AA patients ( $P=0.08$; Figure 8.4 ). GFR showed no significant change during EXP3174 infusion, but FF decreased by $14.0 \%$ in AA patients and by $9.0 \%$ in CC patients $(P=0.05)$. RVR fell by $15.1 \%$ in AA patients compared to $7.5 \%$ in $C C$ patients ( $P=0.06$ vs. AA response). APRC and Angll rose, and aldosterone fell to a comparable degree in both groups. The time (i.e. dose of EXP3174) at which maximum responses were found were comparable between both groups, and were on average between 60 and 90 minutes for all variables.

\section{High salt}

Significant differences for blood pressure responses between the genotype groups were found. On average SBP fell by $12 \mathrm{mmHg}(6.6 \%)$ in the AA patients, compared to only $2 \mathrm{mmHg}(1.3 \%)$ in the CC patients $(P<0.01$; Figure 8.1$)$. For DBP these figures were 7 and $2 \mathrm{mmHg}(6.7$ and $2.4 \%)$, respectively $(P<0.05$; Figure 8.2) and for MBP 10 and $2 \mathrm{mmHg}(7.5$ and $1.8 \%)(P<0.05)$. PP did not respond differently between the genotype groups. HR increased in CC patients by $4 \mathrm{bpm}$ versus 2 bpm in AA patients ( 3.9 versus $7.0 \%)(P=0.06$; Figure 8.3$)$. The increments in ERPF (Figure 8.4), GFR, APRC and Angll, as well as the decreases in FF, RVR and aldosterone were not significantly different between the genotype groups. As during low salt, the time at which maximum responses were found were comparable between both groups, and were on average between 60 and 90 minutes for all variables.

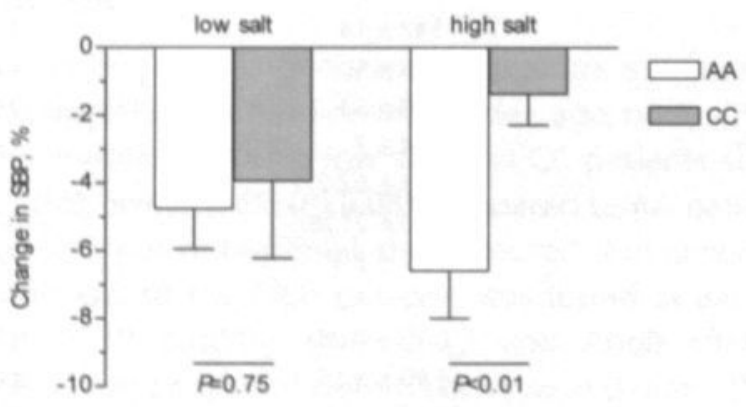

Figure 8.1. Maximum percentage change of SBP to infusion of EXP3174. 


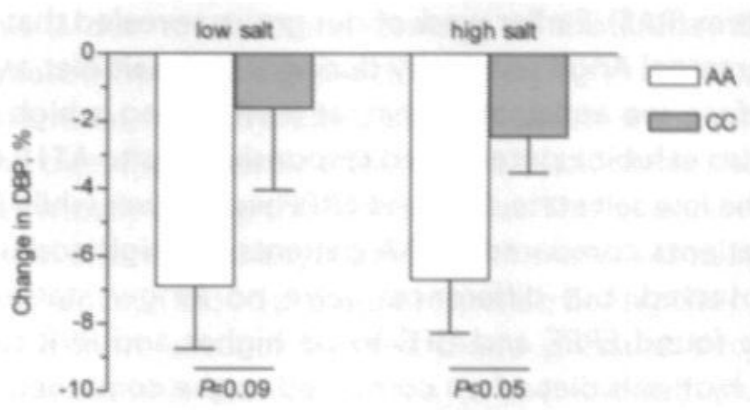

Figure 8.2. Maximum percentage change of DBP to infusion of EXP3174.

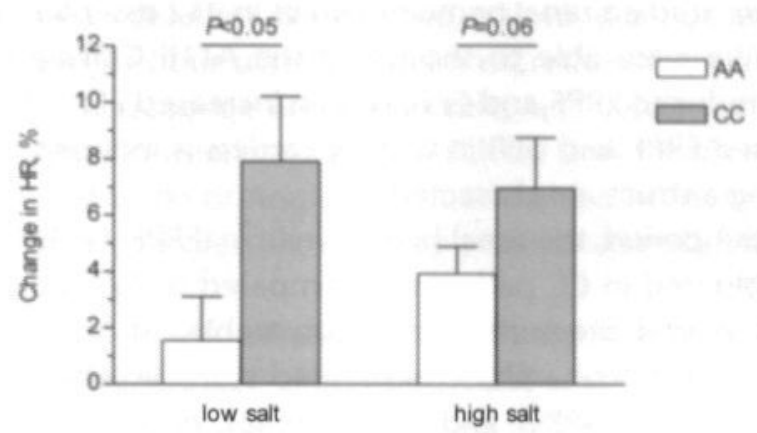

Figure 8.3. Maximum percentage change of HR to infusion of EXP3174.

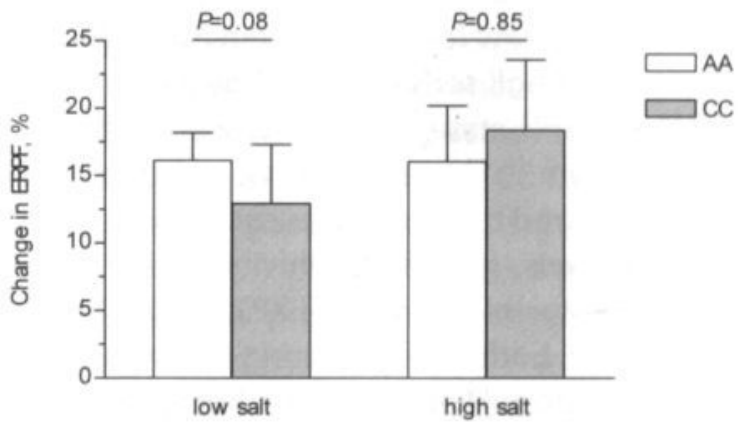

Figure 8.4. Maximum percentage change of ERPF to infusion of EXP3174.

\section{Discussion}

This study investigated the systemic and renal hemodynamic as well as humoral responses to acute AT1R blockade with the active metabolite of losartan (EXP3174) in relation to the AT1R A1166C polymorphism in essential hypertensives. Patients were examined during both a low and high sodium diet in order to allow evaluation of responses at different levels of activity of the renin- 
angiotensin system (RAS). Earlier work of our group revealed that CC patients have an increased intrarenal Angll sensitivity during a high salt diet as compared to AA patients. ${ }^{9}$ Therefore, we anticipated that, at least during a high salt diet, C allele carriers would also exhibit a potentiated responsiveness to AT1R blockade.

At baseline, in the low salt state, GFR and ERPF were lower while RVR tended to be higher in CC patients compared to AA patients. At high sodium intake, similar trends were observed, but differences were no longer statistically significant. Miller et al. also found ERPF and GFR to be higher and RVR to be lower in AA subjects during high salt diet when compared to the combined group of $A C$ and CC individuals. ${ }^{10}$ However, a comparable study of Hilgers et al. in male normo- or mildly hypertensives could not confirm this. ${ }^{17}$ We recently completed a large study in which we studied renal hemodynamics in 212 essential hypertensives on a low salt diet. We were able to show that the AT1R C allele is independently associated with reduced ERPF and GFR, and an increased FF. ${ }^{18}$ These data indicate that the decreased ERPF and GFR in C allele carriers is independent from sodium status, suggesting a structural characteristic.

During the low salt period, the renal hemodynamic (ERPF, FF, RVR) effects of AT1R blockade were blunted in CC patients as compared to AA patients, whereas the systemic effects (blood pressure) were comparable. At high salt the opposite (comparable renal hemodynamics and blunted systemic effects) was found. The humoral effects (Angll, APRC and aldosterone) of AT1R blockade were as expected, but showed no relationship with genotype during either diet. The blunted renal hemodynamic effects in CC patients during sodium restriction are a major finding of this study. At low levels of sodium intake higher circulating levels of Angll, increased adrenal Angll sensitivity and decreased renal Angll sensitivity are to be expected. ${ }^{19,20}$ In this state, the renovascular effects of AT1R blockade should be at their maximum. ${ }^{21}$ The fact that CC subjects show blunted effects upon AT1R blockade compared to AA subjects could theoretically be explained by higher circulating Angll levels, greater sensitivity or affinity of the receptor for Angll, or suboptimal receptor blockade by EXP3174 in these subjects. As Angll levels were comparable for both groups during all EXP3174 infusion steps, the latter two possibilities are more likely. In our earlier work on Angll infusions, ${ }^{9}$ we speculated that CC patients on a high sodium diet behave as if they are relatively volume-overloaded in comparison to AA subjects. The present study which examined the role of endogenous rather than exogenous Angll, corroborates that notion if we assume that CC patients also had increased sensitivity or affinity for intrarenal Angll at low salt intake. This could not only explain why basal renal hemodynamics were significantly lower in CC patients than in AA patients on low salt diet, but also why EXP3174 was not able to elicit a 'full' response in CC subjects. Our findings at low salt could mean a functional 'overadaptation' to sodium restriction, i.e. to retain as much sodium as possible. A second explanation 
could be that this is due to structural damage of the kidney by longstanding exposition to increased intrarenal Angll activity.

In contrast to the renal hemodynamic effects, which were most pronounced during the low salt diet, the systemic effects of AT1R blockade showed genotyperelated differences mostly during the high salt diet. This underscores the fact that Angll has differential effects on the systemic and the renal vasculature. The finding of a significant difference in blood pressure response during the high salt diet was mainly caused by a more distinct blunted blood pressure decrease in the CC genotype group during this diet compared to the low salt diet, as the blood pressure response in AA patients was comparable at both salt diets. It seems reasonable to assume that the blood pressure findings will be more distinct if a better sodium-replete situation is obtained, as we did not succeed to study patients with a mean 24 hour urinary sodium excretion of about $220 \mathrm{mmol} / \mathrm{day}$. The differences in HR response are remarkable, but consistent with our earlier findings from the Angll infusion studies in which CC patients showed a decrease in HR following administration of Angll. ${ }^{9}$ Whether the rise in HR is the cause of the blunted decrease in blood pressure or an epiphenomenon cannot be concluded from these data.

Miller et al. also found genetic differences in the response to AT1R blockade, but the opposite of what we found: $C$ allele carriers ( $A C$ and $C C$ !) were the only ones to show an effect of AT1R blockade, i.e. a decrease in MBP and increase in GFR. ${ }^{10}$ As their study is fundamentally different from ours, we can only speculate about this discrepancy. Firstly, when acute effects of AT1R blockade are being studied it is more appropriate to do this with an intravenous drug, rather than with an oral prodrug. Since Miller and coworkers did not measure Angll levels after losartan administration, we cannot be sure that they achieved the same amount of AT1R blockade in the two genotype groups. Secondly, CC subjects were not studied as a separate group but they were pooled with AC subjects. In fact, this combined group existed of 29 AC and only 7 CC subjects. As the mode of inheritance of the AT1R A1166C polymorphism is probably recessive, ${ }^{9}$ the characteristics in this pooled group are mainly caused by the A allele. Thirdly, only responses on blood pressure and GFR were found, not on ERPF. Finally, their data were obtained only during a high-salt diet. To the best of our knowledge no other studies are available that examined renal function in the low salt state in relation to the AT1R A1166C polymorphism.

In line with other observations, 22 we found that aldosterone concentrations decreased after losartan administration. However, we did not find any difference between the genotype groups with respect to this effect. This finding supports other studies that could not find differences in the genotype groups when Angll was infused.9,17 One could hypothesize, therefore, that the adrenal AT1R to some extent is genetically different from the the renal AT1R. 
It remains elusive, why the $C$ allele of the AT1R A1166C polymorphism is associated with increased sensitivity to Angll and, in the end, an increased incidence of cardiovascular disease. ${ }^{3-5,23-30}$ As we and others ${ }^{31}$ did not find differences in the number of platelet AT1R binding sites $\left(B_{\max }\right)$ and Angll affinity $\left(K_{\mathrm{D}}\right)$, differences probably cannot be explained by the number and function of the AT1R. On the other hand, one should realize that the platelet model is just a surrogate model for the RAS in the systemic circulation, as well as in the kidneys and adrenals. With a low number of AT1Rs ${ }^{31-33}$ per platelet (about 4 to 6) the limitations of this model in showing prominent differences in AT1R number and function are clear. Because this polymorphism is located in the uncoding 3 '-region of the AT1R gene it could be in linkage disequilibrium with a coding mutation nearby. However, Poirier et al. rescanned the AT1R gene, but did not find new variants which could affect the regulation of the gene in response to Angll. ${ }^{34}$ Furthermore, the binding of AUF1, a protein that affects AT1R mRNA stability through binding to AU-rich regions of the uncoding 3'-untranslated region of the mRNA, is not affected by this polymorphism..$^{35}$

In this study only acute effects of AT1R blockade were studied. In a prospective study in which ambulatory blood pressures were measured in AA and CC patients that were treated with losartan-based therapy, we were able to confirm the finding of a blunted blood pressure response in CC patients. ${ }^{36}$ One could hypothesize that a group of approximately $10 \%$ of the essential hypertensive patients (i.e. CC subjects) can be selected that should preferably not be treated with AT1R antagonists.

In conclusion, we have found that in patients with the CC genotype of the AT1R A1166C polymorphism renal function is impaired and systemic and renal hemodynamic effects of AT1R blockade effects are blunted, compared to patients with the AA genotype. In line with earlier studies this again confirms the concept of increased Angll sensitivity in patients carrying the C allele of the AT1R A1166C polymorphism. 


\section{References}

1. Cusi D, Barlassina C, Azzani T, Casari G, Citterio L, Devoto M, Glorioso N, Lanzani C, Manunta P, Righetti M, Rivera R, Stella P, Troffa C, Zagato L, Bianchi G. Polymorphisms of alpha-adducin and salt sensitivity in patients with essential hypertension. Lancet 1997;349:1353-7.

2. Turner ST, Schwartz GL, Chapman AB, Boerwinkle E. C825T polymorphism of the G protein beta(3)-subunit and antihypertensive response to a thiazide diuretic. Hypertension 2001;37: 739-43.

3. Tiret L, Bonnardeaux A, Poirier O, Ricard S, Marques-Vidal P, Evans A, Arveiler D, Luc G, Kee F, Ducimetiere $P$, et al. Synergistic effects of angiotensin-converting enzyme and angiotensin-11 type 1 receptor gene polymorphisms on risk of myocardial infarction. Lancet 1994:344:910-3.

4. Bonnardeaux A, Davies E, Jeunemaitre X, Fery I, Charru A, Clauser E, Tiret L, Cambien F, Corvol P, Soubrier F. Angiotensin II type 1 receptor gene polymorphisms in human essential hypertension. Hypertension 1994;24:63-9.

5. Wang WY, Zee RY, Morris BJ. Association of angiotensin II type 1 receptor gene polymorphism with essential hypertension. Clin Genet 1997:51:31-4.

6. Nalogowska-Glosnicka K, Lacka BI, Zychma MJ, Grzeszczak W, Zukowska-Szczechowska E, Poreba R, Michalski B, Kniazewski B, Rzempoluch J. Angiotensin II type 1 receptor gene A1166C polymorphism is associated with the increased risk of pregnancy-induced hypertension. Med SCi Monit 2000;6:523-9.

7. Takami S, Imai Y, Katsuya T, Ohkubo T, Tsuji I, Nagai K, Satoh H, Hisamichi S, Higaki J, Ogihara T. Gene polymorphism of the renin-angiotensin system associates with risk for lacunar infarction. The Ohasama study. Am J Hypertens 2000;13:121-7.

8. Buraczynska M, Ksiazek P, Zaluska W, Spasiewicz D, Nowicka T, Ksiazek A. Angiotensin II type 1 receptor gene polymorphism in end-stage renal disease. Nephron 2002;92:51-5.

9. Spiering W, Kroon AA, Fuss-Lejeune MM, Daemen MJ, de Leeuw PW. Angiotensin II sensitivity is associated with the angiotensin II type 1 receptor $A(1166) C$ polymorphism in essential hypertensives on a high sodium diet. Hypertension 2000;36:411-6.

10. Miller JA, Thai K, Scholey JW. Angiotensin II type 1 receptor gene polymorphism predicts response to losartan and angiotensin II. Kidney Int 1999;56:2173-80.

11. 1999 World Health Organization-International Society of Hypertension Guidelines for the Management of Hypertension. Guidelines Subcommittee. J Hypertens 1999;17:151-83.

12. Cole BR, Giangiacomo J, Ingelfinger JR, Robson AM. Measurement of renal function without urine collection. A critical evaluation of the constant-infusion technic for determination of inulin and para-aminohippurate. NEngl J Med 1972;287:1109-14.

13. Simon D, Hartmann DJ, Badouaille G, Caillot G, Guyenne TT, Corvol P, Pau B, Marchand J. Two-site direct immunoassay specific for active renin. Clin Chem 1992;38:1959-62.

14. Nussberger J, Brunner DB, Waeber B, Brunner HR. True versus immunoreactive angiotensin II in human plasma. Hypertension 1985;7:11-7.

15. Kubasik NP, Warren K, Sine HE. Evaluation of a new commercial radioassay kit for aldosterone using an iodinated tracer. Clin Biochem 1979;12:59-61.

16. Brun C. A rapid method for the determination of para-aminohippuric acid in kidney function tests. J Lab Clin Med 1951;37:955-8.

17. Hilgers KF, Langenfeld MR, Schlaich M, Veelken R, Schmieder RE. 1166 A/C polymorphism of the angiotensin II type 1 receptor gene and the response to short-term infusion of angiotensin II. Circulation 1999;100:1394-9.

18. Spiering W, Kroon AA, de Leeuw PW. Impact of the angiotensin II type 1 receptor A1166C polymorphism on renal hemodynamics in essential hypertension. Submitted 2003.

19. Hollenberg NK, Chenitz WR, Adams DF, Williams GH. Reciprocal influence of salt intake on adrenal glomerulosa and renal vascular responses to angiotensin II in normal man. J Clin Invest $1974 ; 54: 34-42$. 
20. Shoback DM, Williams GH, Moore TJ, Dluhy RG, Podolsky S, Hollenberg NK. Defect in the sodiummodulated tissue responsiveness to angiotensin II in essential hypertension. J Clin Invest 1983;72:2115-24.

21. Price DA, De'Oliveira JM, Fisher ND, Hollenberg NK. Renal hemodynamic response to an angiotensin II antagonist, eprosartan, in healthy men. Hypertension 1997;30:240-6.

22. Gandhi SK, Ryder DH, Brown NJ. Losartan blocks aldosterone and renal vascular responses to angiotensin II in humans. Hypertension 1996;28:961-6.

23. Benetos A, Topouchian J, Ricard S, Gautier S, Bonnardeaux A, Asmar R, Poirier O, Soubrier F, Safar $\mathrm{M}$, Cambien $\mathrm{F}$. Influence of angiotensin II type 1 receptor polymorphism on aortic stiffness in never-treated hypertensive patients. Hypertension 1995;26:44-7.

24. Hingorani AD, Jia H, Stevens PA, Hopper R, Dickerson JE, Brown MJ. Renin-angiotensin system gene polymorphisms influence blood pressure and the response to angiotensin converting enzyme inhibition. J Hypertens 1995;13:1602-9.

25. Nakauchi $Y$, Suehiro T, Yamamoto $M$, Yasuoka N, Arii K, Kumon Y, Hamashige N, Hashimoto K. Significance of angiotensin I-converting enzyme and angiotensin II type 1 receptor gene polymorphisms as risk factors for coronary heart disease. Atherosclerosis 1996;125:161-9.

26. Berge KE, Bakken A, Bohn M, Erikssen J, Berg K. A DNA polymorphism at the angiotensin II type 1 receptor (AT1R) locus and myocardial infarction. Clin Genet 1997;52:71-6.

27. Doria A, Onuma T, Warram JH, Krolewski AS. Synergistic effect of angiotensin II type 1 receptor genotype and poor glycaemic control on risk of nephropathy in IDDM. Diabetologia 1997;40:1293-9.

28. Osterop AP, Kofflard MJ, Sandkuijl LA, ten Cate FJ, Krams R, Schalekamp MA, Danser AH. AT1 receptor A/C1166 polymorphism contributes to cardiac hypertrophy in subjects with hypertrophic cardiomyopathy. Hypertension 1998;32:825-30.

29. Szombathy T, Szalai C, Katalin B, Palicz T, Romics L, Csaszar A. Association of angiotensin II type 1 receptor polymorphism with resistant essential hypertension. Clin Chim Acta 1998;269:91-100.

30. Kainulainen K, Perola M, Terwilliger J, Kaprio J, Koskenvuo M, Syvanen AC, Vartiainen E, Peltonen L. Kontula K. Evidence for involvement of the type 1 angiotensin II receptor locus in essential hypertension. Hypertension 1999;33:844-9.

31. Paillard F, Chansel D, Brand E, Benetos A, Thomas F, Czekalski S, Ardaillou R, Soubrier F. Genotype-phenotype relationships for the renin-angiotensin-aldosterone system in a normal population. Hypertension 1999;34:423-9.

32. Makarious M, Pawlak M, Campbell LV, Timmermans V, Duggan K, Charlesworth JA, Macdonald GJ. The platelet angiotensin II receptor in type I diabetes: studies in patients with and without nephropathy. Eur J Clin Invest 1993;23:517-21.

33. Mann JF, Sis J, Ritz E. 1251-Angiotensin II binding to human blood cells. J Hypertens 1985;3:131-7.

34. Poirier O, Georges JL, Ricard S, Arveiler D, Ruidavets JB, Luc G, Evans A, Cambien F, Tiret L. New polymorphisms of the angiotensin II type 1 receptor gene and their associations with myocardial infarction and blood pressure: the ECTIM study. Etude Cas-Temoin de l'Infarctus du Myocarde. J Hypertens 1998;16:1443-7.

35. Pende A, Giacche M, Castigliola L, Contini L, Passerone G, Patrone M, Port JD, Lotti G. Characterization of the binding of the RNA-binding protein AUF1 to the human AT(1) receptor mRNA. Biochem Biophys Res Commun 1999;266:609-14.

36. Spiering W, Kroon AA, de Leeuw PW. Genetic contribution to the chronic effects of angiotensin II type 1 receptor blockade. Submitted 2003. 


\section{Chapter 9}

\section{Genetic contribution to the chronic effects of angiotensin II type 1 receptor blockade}

Wilko Spiering, Léon H. Henskens, Abraham A. Kroon, Henri E. Stoffers, Peter W. de Leeuw 


\section{Abstract}

\section{Background}

Clinical observations point towards heterogeneity in patients' responses to antihypertensive drugs. In all likelihood, this is at least in part genetically determined. We earlier showed that in patients with the CC genotype of the angiotensin II (Angll) type 1 receptor (AT1R) A1166C polymorphism blunted renal and systemic hemodynamic effects can be found during acute blockade of the AT1R. The present study was conducted to investigate whether blood pressure responses in CC carriers are also blunted during chronic AT1R blockade.

\section{Methods}

After 3 weeks withdrawal of antihypertensive drugs, a 12-week losartan-based treatment was started in 31 essential hypertensive patients genotyped for the AT1R A1166C polymorphism (16 AA and $15 \mathrm{CC}$ ). Office (week $0,2,4,6,8,12$ ) and ambulatory (week 0, 6, 12) blood pressures were measured. The losartan dosage was increased and/or hydrochlorothiazide was added when office blood pressures did not reach 140/90 $\mathrm{mmHg}$.

\section{Results}

All 31 patients finished the trial. Both genotype groups needed comparable treatment changes during the trial to reach desired blood pressure goals. No differences in office blood pressures were found between the two genotype groups. At week 12 a significant blunted reduction in systolic (AA: $19.7 \pm 2.6 \%$; CC: $14.1 \pm 1.4 \% ; P<0.05$ ) and diastolic (AA: $17.6 \pm 2.4 \%$; $C$ : $11.1 \pm 1.7 \% ; P<0.05)$ ambulatory daytime blood pressures were found in $C C$ patients compared to AA patients. Nighttime and 24 hour blood pressures showed the same tendency, but were not significantly different.

\section{Conclusion}

This study shows that the blood pressure responses to chronic AT1R blockade are at least in part genetically determined. 


\section{Introduction}

One of the striking features of essential hypertension is the heterogeneity of patients' responses to antihypertensive drugs. Recent data indicate that this is, at least partly, genetically determined and that genetic polymorphisms in effector systems may predict the responsiveness to pharmacological agents. ${ }^{1,2}$ An outstanding example where this supposition could be tested is the interaction between the polymorphisms of the angiotensin II (AngII) type 1 receptor (AT1R) and the response to AT1R blockade. The gene coding for the ATIR has a polymorphism (A1166C) in the 3 '-untranslated region, which was found to be associated with myocardial infarction, ${ }^{3}$ hypertension, ${ }^{4.5}$ pregnancy-induced hypertension, ${ }^{6}$ lacunar infarction, ${ }^{7}$ and faster deterioration of renal function. ${ }^{8}$ We showed that Angll sensitivity is also associated with this polymorphism, with C allele carriers showing an increased renovascular sensitivity to Angll. ${ }^{9}$ Very recently, we found that $\mathrm{CC}$ subjects on a low salt diet have a blunted response of blood pressure, effective renal plasma flow, filtration fraction and renal vascular resistance to acute AT1R blockade as compared to AA patients, whereas at high salt, this was only true for blood pressure. ${ }^{10}$ Whether these findings in the acute situation are clinically relevant in terms of blunted blood pressure reduction with chronic AT1R blockade in CC patients still remains unanswered. This prompted us to conduct a study on the blood pressure reductions with losartan in hypertensive patients with either the AA or the CC genotype. By selecting patients who were homozygous for either the wild type or the mutant receptor gene, we aimed to maximize the contrast between groups. As the clinical relevance was the main incentive to conduct this study, we measured blood pressure both by means of sphygmomanometry and by means of 24 hour ambulatory blood pressure measurements ( $A B P M)$. Based on our earlier findings we hypothesized that $C$ allele carriers would exhibit a blunted response as compared to AA patients.

\section{Methods}

\section{Study population}

A genetic database of hypertensive patients from the Hypertension Research Unit of the University Hospital Maastricht and from a general practice participating in the Hippocrates Study " was screened for those genotyped for the AT1R A1166C polymorphism. Patients entered the study if they fulfilled all the inclusion criteria: either the AA (wildtype) or CC (mutant) genotype of the AT1R A1166C polymorphism, age between 18 and 80 years, Caucasian, untreated blood pressure between 140 and $210 \mathrm{mmHg}$ systolic and/or 90 and $110 \mathrm{mmHg}$ diastolic, 
able to stop antihypertensive medication for 3 weeks. Exclusion criteria were diabetes, secondary hypertension, congestive heart failure (New York Heart Association classes II through IV), hepatic ( $\geq$ Child-Pugh B) or renal insufficiency (creatinine clearance $<60 \mathrm{~mL} / \mathrm{min}$ ). Thirty-one hypertensive patients (16 AA and 15 CC) were selected matched for age, sex and body mass index (BMI). All patients followed a washout period of their antihypertensive treatment for at least 3 weeks, at the end of which a 24 hour ABPM was executed. Hereafter, treatment with losartan for 12 weeks was started. Patients were instructed to use a liberal salt diet during the whole study. All selected patients gave written informed consent to participate in the study. The study was approved by the Medical Ethics Committee of the University Hospital Maastricht.

\section{Blood pressure measurements}

Office blood pressure measurements were obtained during the visits at week 0,2 , $4,6,8$ and 12 of the study. Using a sphygmomanometer, three measurements were performed at 2-minutes intervals after 10 minutes of rest in the sitting position. All patients were seen by one of our group (L.H.H.). For analysis the mean of these 3 office measurements were used. Hypertension was defined as systolic blood pressure (SBP) $\geq 140 \mathrm{mmHg}$ and/or diastolic blood pressure (DBP) $\geq 90$ $\mathrm{mmHg}$ according to the European Society of Hypertension-European Society of Cardiology 2003 Guidelines on Hypertension. ${ }^{12}$ Ambulatory blood pressure readings were performed at week 0,6 and 12 of the trial using the SpaceLabs 90217 device (SpaceLabs ${ }^{\mathrm{T}} \mathrm{M}$, Redmond, WA, USA). Patients were monitored during normal daily activity and recordings were obtained every 15 minutes during daytime (7:00 AM to 11:00 PM) and every 30 minutes during nighttime (11:00 PM to 7:00 AM). Blood pressure data were transferred into a personal computer and analysed by the dabl" ABPM program (ECF Medical Ltd., Dublin, Ireland) for the following derivatives: time weighted mean blood pressure, load, leese, blood pressure variability (standard deviation of mean blood pressure, coefficient of variation, root mean square of successive deviations), number of load events, number of leese events, maximum load duration, and maximum leese duration. All these variables were calculated for the initial hour, daytime (defined as the period from 9:00 AM to 9:00 PM less the initial hour), and nighttime (defined as the period from 1:00 AM to 6:00 AM). Mean, load, and leese were also determined for the entire 24 hour period. Lastly, the percentage dipping was calculated. All analyses were applied to SBP, DBP, mean blood pressure (MBP), pulse pressure $(\mathrm{PP})$, and heart rate (HR), but only when data were valid (i.e. when $M B P>0$ and $\mathrm{SBP}>\mathrm{MBP}>\mathrm{DBP}$ ). For definition of these variables see appendix. 


\section{Drug administration}

Treatment with losartan $50 \mathrm{mg}$ per day was initiated at baseline. At week 2, 4, 6 and 8 medication could be adjusted if office blood pressure did not reach the following goals: SBP $\leq 140 \mathrm{mmHg}$ and DBP $\leq 90 \mathrm{mmHg}$. Adjustments were executed stepwise: step 2: losartan $100 \mathrm{mg}$ per day; step 3: losartan $100 \mathrm{mg}$ per day and hydrochlorothiazide $25 \mathrm{mg}$ per day; step 4: losartan $100 \mathrm{mg}$ per day and hydrochlorothiazide $50 \mathrm{mg}$ per day. Serum creatinine levels were measured at week 0 and 4 to rule out a possible decreased kidney function. Patients with levels exceeding $150 \mu \mathrm{mol} / \mathrm{L}$ at week 4 were excluded from the trial.

\section{Genetic analysis}

DNA was extracted from whole blood with the use of the QIAamp* Blood Kit (Qiagen Inc., Valencia, CA, USA). The AT1R A1166C polymorphism was genotyped with means of mutagenically separated PCR, as described earlier. ${ }^{9}$

\section{Statistical analysis}

Comparisons of means and proportions between the two genotype groups were performed using the Mann-Whitney $U$ and Chi-Square test, respectively. Comparisons of drug effects within the groups during time were made using Wilcoxon Signed Ranks test or Friedman test when applicable. The study had a power of 0.8 to detect a difference in mean ambulatory 24 hour blood pressure of $\geq 7 \%$ between groups. Results are expressed as means \pm standard error of the mean (SEM). A P-value of less than 0.05 was considered to be statistically significant. Statistical analyses were performed using SPSS 11.0 for Windows (SPSS Inc., Chicago, IL, USA).

\section{Results}

\section{Baseline characteristics}

Baseline characteristics of the two genotype groups are summarized in Table 9.1. There were no significant differences in gender, age, BMI, waist/hip ratio, number of smokers, office and ambulatory blood pressures, HR, and plasma creatinine. 
Table 9.1. Baseline characteristics of the study population.

\begin{tabular}{|c|c|c|}
\hline & AA & cc \\
\hline Number, $n(\%)$ & $16(51.6)$ & $15(48.4)$ \\
\hline Males/females, $\boldsymbol{n}$ & $12 / 4$ & $8 / 7$ \\
\hline Age, years & $57 \pm 3$ & $59 \pm 2$ \\
\hline $\mathrm{BMI}, \mathrm{kg} / \mathrm{m}^{2}$ & $26.2 \pm 0.8$ & $27.9 \pm 0.9$ \\
\hline Waist/hip ratio & $0.90 \pm 0.03$ & $0.91 \pm 0.03$ \\
\hline Smoking yes/no, $n$ & $4 / 12$ & $4 / 11$ \\
\hline Office SBP, $m m H g$ & $176 \pm 6$ & $170 \pm 6$ \\
\hline Office DBP, $m m H g$ & $102 \pm 4$ & $104 \pm 2$ \\
\hline Office HR, beats/min & $76 \pm 3$ & $80 \pm 2$ \\
\hline Daytime SBP, $\mathrm{mmHg}$ & $168 \pm 5$ & $158 \pm 3$ \\
\hline Daytime DBP, $\mathrm{mmHg}$ & $103 \pm 3$ & $98 \pm 3$ \\
\hline Nighttime SBP, $m m \mathrm{Hg}$ & $143 \pm 4$ & $138 \pm 4$ \\
\hline Nighttime DBP, $m m H g$ & $85 \pm 3$ & $82 \pm 2$ \\
\hline 24 hour SBP, $\mathrm{mmHg}$ & $163 \pm 5$ & $154 \pm 3$ \\
\hline 24 hour DBP, $\mathrm{mmHg}$ & $99 \pm 3$ & $94 \pm 2$ \\
\hline Creatinine, $\mu \mathrm{mol} / \mathrm{L}$ & $101 \pm 7$ & $91 \pm 6$ \\
\hline
\end{tabular}

n: number; BMI: body mass index; SBP: systolic blood pressure; DBP: diastolic blood pressure; HR: heart rate.

\section{Treatment regimens}

All 31 patients completed the 12 weeks of the trial. Treatment changes during the trial were comparable between the groups (Table 9.2). The effective antihypertensive regimen was reached at week 8 in all patients.

Table 9.2. Patient numbers with respect to treatment modalities during the trial.

\begin{tabular}{|c|c|c|c|c|c|c|c|c|c|}
\hline \multirow[b]{2}{*}{ Week } & \multicolumn{2}{|c|}{ LOS $50 \mathrm{mg}$} & \multicolumn{2}{|c|}{ LOS $100 \mathrm{mg}$} & \multicolumn{2}{|c|}{$\begin{array}{l}\text { LOS } 100 \mathrm{mg} \\
\text { HCTZ } 25 \mathrm{mg}\end{array}$} & \multicolumn{2}{|c|}{$\begin{array}{l}\text { LOS } 100 \mathrm{mg} \\
\text { HCTZ } 50 \mathrm{mg}\end{array}$} & \multirow[b]{2}{*}{ Total } \\
\hline & AA & $\mathrm{CC}$ & AA & $\mathrm{CC}$ & AA & CC & AA & $\mathrm{CC}$ & \\
\hline 0 & 16 & 15 & & & & & & & 31 \\
\hline 2 & 1 & 2 & 15 & 13 & & & & & 31 \\
\hline 4 & 1 & 2 & 1 & 2 & 14 & 11 & & & 31 \\
\hline 6 & 1 & 2 & 1 & 2 & 5 & 4 & 9 & 7 & 31 \\
\hline 8 & 1 & 2 & 1 & 2 & 4 & 3 & 10 & 8 & 31 \\
\hline 12 & 1 & 2 & 1 & 2 & 4 & 3 & 10 & 8 & 31 \\
\hline
\end{tabular}

LOS: losartan; HCTZ: hydrochlorothiazide.

\section{Office blood pressure measurements}

As shown in Figure 9.1, comparable decreases from week 0 to week 12 for both office SBP (AA: from $176 \pm 6 \mathrm{mmHg}$ to $140 \pm 5 \mathrm{mmHg}$, mean decrease: $20.1 \pm 2.5 \%$, $P<0.0001$; CC: from $170 \pm 6 \mathrm{mmHg}$ to $136 \pm 3 \mathrm{mmHg}$, mean decrease: $19.4 \pm 2.0 \%$, 
$P<0.0001$ ) and office DBP (AA: from $102 \pm 4 \mathrm{mmHg}$ to $85 \pm 2 \mathrm{mmHg}$, mean decrease: $16.1 \pm 2.3 \%, P<0.0001$; CC: from $104 \pm 2 \mathrm{mmHg}$ to $86 \pm 2 \mathrm{mmHg}$, mean decrease: $16.1 \pm 2.4 \%, P<0.0001)$ were found. Office $H R$ did not change significantly during the 12 weeks in both genotype groups (AA: from $76 \pm 3 \mathrm{bpm}$ to $76 \pm 3 \mathrm{bpm}$; CC: from $80 \pm 2 \mathrm{mmHg}$ to $77 \pm 2 \mathrm{mmHg}$ ).

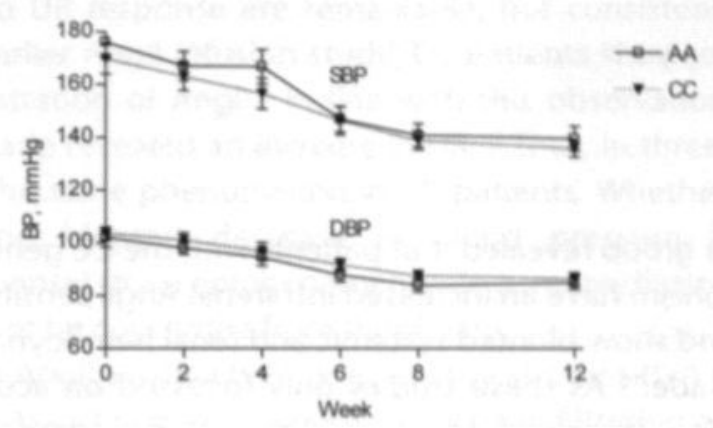

Figure 9.1. Office SBP and DBP.

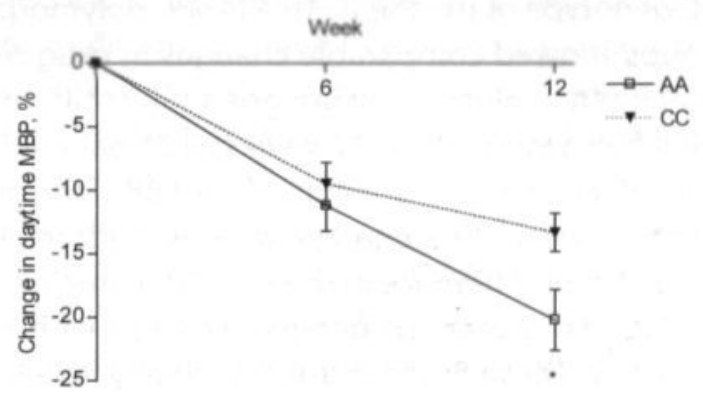

Figure 9.2. Change in daytime MBP. ${ }^{*} P<0.05$ vs. AA.

\section{Ambulatory blood pressure measurements}

At week 6 both genotype groups showed comparable decreases in daytime SBP (AA: $14.6 \pm 2.0 \%$; CC: $10.3 \pm 1.6 \% ; P=0.10$ ), DBP (AA: $10.2 \pm 2.0 \%$; CC: $8.1 \pm 1.8 \% ; P=0.44$ ) and MBP (AA: $11.2 \pm 2.0 \%$; CC: $9.5 \pm 1.7 \% ; P=0.52$ ) compared to week 0 . Decreases in nighttime and 24 hour blood pressures from week 6 to week 0 were also comparable between both genotype groups. Compared to AA patients CC patients showed significantly blunted decreases from week 0 to week 12 in daytime SBP (AA: 19.7 $\pm 2.6 \%$; CC: $14.1 \pm 1.4 \%$; $P<0.05$ ), DBP (AA: $17.6 \pm 2.4 \%$; CC: $11.1 \pm 1.7 \% ; P<0.05$ ) and MBP (AA: $20.2 \pm 2.4 \%$; CC: $13.3 \pm 1.5 \% ; P<0.05$; Figure 9.2). No differences at week 12 between the genotype groups were found during nighttime and during 24 hours. At week 12, CC patients showed a small but significant increase in daytime HR (from $77 \pm 3$ beats/min to $81 \pm 3$ beats/min, 
$P<0.05$ vs. week 0 ), whereas AA patients showed no significant change (from $78 \pm 3$ beats $/ \mathrm{min}$ to $78 \pm 3$ beats $/ \mathrm{min}, P=0.96$ ). Changes in blood pressures and HR from week 6 to week 12 were not significantly different between the genotype groups. Pulse pressure, load, leese, blood pressure variability, number of load and leese events, maximum load and leese duration, and percentage dipping were not significantly different between the genotype groups during the 12 weeks of the study.

\section{Discussion}

Earlier work of our group revealed that patients with the CC genotype of the AT1R A1166C polymorphism have an increased intrarenal Angll sensitivity as compared to AA patients, ${ }^{9}$ and show blunted systemic and renal hemodynamic responses to acute AT1R blockade. ${ }^{10}$ As these studies only focussed on acute hemodynamic effects, the question remained if these findings can be extrapolated to the daily clinical situation. This prompted us to evaluate the blood pressure responses to chronic AT1R blockade with losartan during a trial of 12 weeks duration in patients with the AA and CC genotype of the the AT1R A1166C polymorphism.

Both genotype groups showed comparable changes in drug regimen during the 12 weeks of the trial if office blood pressure goals (SBP $\leq 140 \mathrm{mmHg}$ and $\mathrm{DBP} \leq 90$ $\mathrm{mmHg}$ ) were not reached. During these 12 weeks all 31 patients (16 AA and $15 \mathrm{CC}$ ) showed a significant decrease $(\approx 15-20 \%)$ in office SBP and DBP, which was not significantly different between the genotype groups. With respect to ambulatory blood pressures a significant difference in the fall of daytime blood pressures (SBP, $\mathrm{DBP}$, and $\mathrm{MBP}$ ) was found between the genotype groups with a blunted response in CC patients at week 12. These findings are completely in line with our study on the effects of acute AT1R blockade. The discrepancy in this trial between office and ambulatory blood pressure findings once again illustrates the superiority of ABPM, even though office blood pressure measurements in this study were obtained according to a standard protocol by one investigator.

One could argue that the blood pressure differences found may not solely be ascribed to diminished responsiveness to AT1R blockade in CC patients. Adding hydrochlorothiazide, however, activates the renin-angiotensin system (RAS) and therefore potentiates the blood pressure lowering effects of losartan. As, in our theory, CC patients have an increased sensitivity to Angll, further activating the RAS (by means of a diuretic) does not improve the blood pressure lowering effects of losartan in these subjects, in contrast to AA patients where losartan treatment will be further potentiated. As the treatment regimens used during the 12 weeks were nearly identical in both groups, and since known confounders (e.g. renal function, smoking, etc.) of the blood pressure response were similar in both 
groups, we can safely conclude that the blunted response in CC patients to losartan-based treatment is related to the genetic mutation of these subjects.

As we only tested losartan, we cannot rule out that our findings are a specific drug effect rather than a class effect. It would be interesting, therefore, to repeat this study with other AT1R antagonists which produce more extensive blockade of the AT1R.

The differences in HR response are remarkable, but consistent with our earlier findings. In our earlier Angll infusion study, CC patients showed a decrease in HR following administration of Angll. ${ }^{9}$ In line with this observation, our study with acute AT1R blockade revealed an increase in HR. ${ }^{10}$ Thus, in three separate studies we have shown the same phenomenon in CC patients. Whether the rise in HR is the cause of the blunted decrease in blood pressure (i.e. exaggerated baroreceptor response) or an epiphenomenon (e.g. more diastolic left ventricular dysfunction) cannot be concluded from these data.

Besides increased Angll sensitivity,, 910 we recently showed that the AT1R A1166C polymorphism is associated with lower glomerular filtration rate and effective renal plasma flow, and increased filtration fraction. ${ }^{15}$ This indirectly suggests that the $C$ allele is associated with (longterm) increased sensitivity to, or activity of, Angll. Others showed increased vascular responsiveness of coronary and internal mammarian arteries to different stimuli in patients carrying the $C$ allele. ${ }^{16-18}$ Thus, inere is grovving eviuence that the 2 aneie inueed is associated witn incieased Angll sensitivity with respect to the AT1R A1166C polymorphism. It remains elusive, why the $C$ allele of the AT1R A1166C polymorphism is associated with increased sensitivity to Angll and, in the end, an increased incidence of cardiovascular disease..$^{3-5,19-26}$ As we ${ }^{10}$ and others ${ }^{27}$ did not find differences in the number of platelet AT1R binding sites $\left(B_{\max }\right)$ and Angll affinity $\left(K_{D}\right)$, differences probably cannot be explained by the number and function of the AT1R. On the other hand, one should realize that the platelet model is just a surrogate model for the RAS in the systemic circulation, as well as in the kidneys and adrenals. With a low number of AT1Rs ${ }^{27-29}$ per platelet (about 4 to 6 ) the limitations of this model in showing prominent differences in AT1R number and function are clear. Because this polymorphism is located in the uncoding 3'-region of the AT1R gene it could be in linkage disequilibrium with a coding mutation nearby. However, Poirier et al. rescanned the AT1R gene, but did not find new variants which could affect the regulation of the gene in response to Angll. ${ }^{30}$ Furthermore, the binding of AUF1, a protein that affects AT1R mRNA stability through binding to AU-rich regions of the uncoding 3 '-untranslated region of the $m R N A$, is not affected by this polymorphism. ${ }^{31}$

As this 'chronic' study lasted only 12 weeks, more extended studies are needed to find out if the blunted decrease in blood pressure lasts for longer time periods. It is possible that with time compensatory mechanisms fade out the differences. When, however, the blunted response in CC patients is sustained, one could 
hypothesize that a group of approximately $10 \%$ of the essential hypertensive patients (i.e. CC subjects) can be selected in which antihypertensive treatment should preferably not be initiated with AT1R antagonists.

In conclusion, we have found that in patients with the CC genotype of the AT1R A1166C polymorphism ambulatory blood pressure responses to losartan-based treatment are blunted, compared to patients with the AA genotype. In line with earlier studies this again confirms the concept of increased Angll sensitivity in patients carrying the $C$ allele of the AT1R A1166C polymorphism. 


\section{Appendix}

Time weighted mean blood pressure:

ABPMs consist of samples taken over 24 hours. However they are not always taken at regular intervals (e.g. a patient might accidentally or deliberately take an extra reading or a reading might be missed). To calculate the relevant mean over a certain timeframe this must be taken into account. Each reading therefore represents a timeframe from halfway from its preceding reading to halfway to its succeeding reading. As for the first and last readings of each timeperiod this will give errors, the software program uses a frequency of one reading every 30 minutes $(0.556 \mathrm{kHz})$ to also calculate these timeframes. Missed readings are dealt with by allowing compensation for singletons. The maximum weight for one side (to preceding or succeeding reading) is therefore the period.

Load:

Area of the curve above an upper limit of normality (daytime: 135/90, nighttime: 120/70) expressed as a percentage of the area of the curve above an average of normality (daytime: 122/78, nighttime: 105/60) where values below the upper limit are regarded as being at that limit.

\section{Leese:}

Area of the curve below a lower limit of normality (daytime: 110/66, nighttime: 90/50) expressed as a percentage of the area of the curve below an average of normality (daytime: 122/78, nighttime: 105/60) where values above the lower limit are regarded as being at that limit.

Number of load events:

Distinct occasions when curve goes above normal.

Number of leese events:

Distinct occasions when curve goes below normal.

Maximum load duration:

Longest period when curve is continuously above normal.

Maximum leese duration:

Longest period when curve is continuously below normal.

Percentage dipping:

(daytime value less nighttime value)/(daytime value)·100. 


\section{References}

1. Cusi D, Barlassina C, Azzani T, Casari G, Citterio L, Devoto M, Glorioso N, Lanzani C, Manunta P, Righetti M, Rivera R, Stella P, Troffa C, Zagato L, Bianchi G. Polymorphisms of alpha-adducin and salt sensitivity in patients with essential hypertension. Lancet 1997;349:1353-7.

2. Turner ST, Schwartz GL, Chapman AB, Boerwinkle E. C825T polymorphism of the G protein beta(3)-subunit and antihypertensive response to a thiazide diuretic. Hypertension 2001;37: 739-43.

3. Tiret L, Bonnardeaux A, Poirier O, Ricard S, Marques-Vidal P, Evans A, Arveiler D, Luc G, Kee F, Ducimetiere $P$, et al. Synergistic effects of angiotensin-converting enzyme and angiotensin-II type 1 receptor gene polymorphisms on risk of myocardial infarction. Lancet 1994;344:910-3.

4. Bonnardeaux A, Davies E, Jeunemaitre X, Fery I, Charru A, Clauser E, Tiret L, Cambien F, Corvol P, Soubrier $F$. Angiotensin II type 1 receptor gene polymorphisms in human essential hypertension. Hypertension 1994;24:63-9.

5. Wang WY, Zee RY, Morris BJ. Association of angiotensin II type 1 receptor gene polymorphism with essential hypertension. Clin Genet 1997;51:31-4.

6. Nalogowska-Glosnicka K, Lacka BI, Zychma MJ, Grzeszczak W, Zukowska-Szczechowska E, Poreba R, Michalski B, Kniazewski B, Rzempoluch J. Angiotensin II type 1 receptor gene A1166C polymorphism is associated with the increased risk of pregnancy-induced hypertension. Med Sci Monit 2000;6:523-9.

7. Takami S, Imai Y, Katsuya T, Ohkubo T, Tsuji I, Nagai K, Satoh H, Hisamichi S, Higaki J, Ogihara T. Gene polymorphism of the renin-angiotensin system associates with risk for lacunar infarction. The Ohasama study. Am J Hypertens 2000;13:121-7.

8. Buraczynska M, Ksiazek P, Zaluska W, Spasiewicz D, Nowicka T, Ksiazek A. Angiotensin II type 1 receptor gene polymorphism in end-stage renal disease. Nephron 2002;92:51-5.

9. Spiering W, Kroon AA, Fuss-Lejeune MM, Daemen MJ, de Leeuw PW. Angiotensin II sensitivity is associated with the angiotensin II type 1 receptor $A(1166) C$ polymorphism in essential hypertensives on a high sodium diet. Hypertension 2000;36:411-6.

10. Spiering W, Kroon AA, Fuss-Lejeune MJ, de Leeuw PW. Genetic contribution to the acute effects of angiotensin II type 1 receptor blockade. Submitted 2003.

11. Henskens LH, Spiering W, Stoffers HE, Soomers FL, Vlietinck RF, de Leeuw PW, Kroon AA. Effects of ACE I/D and AT1R-A1166C polymorphisms on blood pressure in a healthy normotensive primary care population: first results of the Hippocates study. J Hypertens 2003;21:81-6.

12. 2003 European Society of Hypertension-European Society of Cardiology guidelines for the management of arterial hypertension. J Hypertens 2003;21:1011-53.

13. Rigat B, Hubert C, Corvol P, Soubrier F. PCR detection of the insertion/deletion polymorphism of the human angiotensin converting enzyme gene (DCP1) (dipeptidyl carboxypeptidase 1). Nucleic Acids Res 1992;20:1433.

14. Shanmugam V, Sell KW, Saha BK. Mistyping ACE heterozygotes. PCR Methods App/ 1993;3:120-1.

15. Spiering W, Kroon AA, de Leeuw PW. Impact of the angiotensin II type 1 receptor A1166C polymorphism on renal hemodynamics in essential hypertension. Submitted 2003.

16. Amant C, Hamon M, Bauters C, Richard F, Helbecque N, McFadden EP, Escudero X, Lablanche JM, Amouyel P, Bertrand ME. The angiotensin II type 1 receptor gene polymorphism is associated with coronary artery vasoconstriction. J Am Coll Cardiol 1997;29:486-90.

17. Henrion D, Amant C, Benessiano J, Philip I, Plantefeve G, Chatel D, Hwas U, Desmont JM, Durand G, Amouyel P, Levy BI. Angiotensin II type 1 receptor gene polymorphism is associated with an increased vascular reactivity in the human mammary artery in vitro. J Vasc Res 1998;35:356-62.

18. van Geel PP, Pinto YM, Voors AA, Buikema H, Oosterga M, Crijns HJ, van Gilst WH. Angiotensin II type 1 receptor $A 1166 \mathrm{C}$ gene polymorphism is associated with an increased response to angiotensin II in human arteries. Hypertension 2000;35:717-21. 
19. Benetos A, Topouchian J, Ricard S, Gautier S, Bonnardeaux A, Asmar R, Poirier O, Soubrier F, Safar $\mathrm{M}$, Cambien $\mathrm{F}$. Influence of angiotensin II type 1 receptor polymorphism on aortic stiffness in never-treated hypertensive patients. Hypertension 1995;26:44-7.

20. Hingorani AD, Jia H, Stevens PA, Hopper R. Dickerson JE, Brown M. Renin-angiotensin system gene polymorphisms influence blood pressure and the response to angiotensin converting enzyme inhibition. J Hypertens 1995;13:1602-9.

21. Nakauchi $Y$, Suehiro T, Yamamoto M, Yasuoka N, Arii K, Kumon Y, Hamashige N, Hashimoto K. Significance of angiotensin I-converting enzyme and angiotensin II type 1 receptor gene polymorphisms as risk factors for coronary heart disease. Atherosclerosis 1996;125:161-9.

22. Berge KE, Bakken A, Bohn M, Erikssen J, Berg K. A DNA polymorphism at the angiotensin II type 1 receptor (AT1R) locus and myocardial infarction. Clin Genet 1997;52:71-6.

23. Doria A, Onuma T, Warram JH, Krolewski AS. Synergistic effect of angiotensin II type 1 receptor genotype and poor glycaemic control on risk of nephropathy in IDDM. Diabetologia 1997;40:1293-9.

24. Osterop AP, Kofflard MJ, Sandkuijl LA, ten Cate FJ, Krams R, Schalekamp MA, Danser AH. ATI receptor A/C1166 polymorphism contributes to cardiac hypertrophy in subjects with hypertrophic cardiomyopathy. Hypertension 1998;32:825-30.

25. Szombathy T, Szalai C, Katalin B, Palicz T, Romics L, Csaszar A. Association of angiotensin II type 1 receptor polymorphism with resistant essential hypertension. Clin Chim Acta 1998;269:91-100.

26. Kainulainen K, Perola M, Terwilliger J, Kaprio J, Koskenvuo M, Syvanen AC, Vartiainen E, Peltonen L, Kontula K. Evidence for involvement of the type 1 angiotensin II receptor locus in essential hypertension. Hypertension 1999:33:844-9.

27. Paillard F, Chansel D, Brand E, Benetos A, Thomas F, Czekalski S, Ardaillou R, Soubrier F. Genotype-phenotype relationships for the renin-angiotensin-aldosterone system in a normal population. Hypertension 1999;34:423-9.

28. Makarious M, Pawlak M, Campbell LV, Timmermans V, Duggan K, Charlesworth JA, Macdonald GJ. The platelet angiotensin II receptor in type I diabetes: studies in patients with and without nephropathy. Eur J Clin Invest 1993;23:517-21.

29. Mann JF, Sis J, Ritz E. 125I-Angiotensin II binding to human blood cells. J Hypertens 1985;3:131-7.

30. Poirier O, Georges JL, Ricard S, Arveiler D, Ruidavets JB, Luc G, Evans A, Cambien F, Tiret L. New polymorphisms of the angiotensin II type 1 receptor gene and their associations with myocardial infarction and blood pressure: the ECTIM study. Etude Cas-Temoin de I'Infarctus du Myocarde. J Hypertens 1998;16:1443-7.

31. Pende A, Giacche M, Castigliola L, Contini L, Passerone G, Patrone M, Port JD, Lotti G. Characterization of the binding of the RNA-binding protein AUF1 to the human AT(1) receptor mRNA. Biochem Biophys Res Commun 1999;266:609-14. 


\section{Chapter 10}

\section{General discussion}




\section{Introduction}

Hypertension is a rather symptomless disorder with a growing incidence, especially in the developed and developing world. Acting as the most important risk factor worldwide for mortality, it in fact is a silent killer.' The majority of patients with hypertension ( $\approx 95 \%$ ) suffer from primary or essential hypertension, meaning that we do not know the exact cause of their hypertension. What we do know, is that this multifactorial disorder is caused by heterogeneous genetic and environmental factors. Accumulating evidence shows that the kidney plays a central role in the pathophysiology of essential hypertension. The reninangiotensin system (RAS) is its most important regulator system that modulates both renal hemodynamics, i.e. glomerular filtration rate and renal blood flow, as well as tubular function. The importance of this system in the pathophysiology of essential hypertension is nicely illustrated by genetic linkage studies, showing that some of the genes (angiotensinogen (AGT), angiotensin-converting enzyme (ACE), and angiotensin II type 1 receptor (AT1R)) encoding the different proteins of the RAS, are potential candidate genes in essential hypertension. Angll is the effector hormone of this system and genes involved in its generation and effect seem to play a prominent role in the genetics of essential hypertension.

\section{Genetic aspects of hypertension}

Chapter 2 provides an overview of the genetic aspects of both monogenic and essential hypertension. As twin and adoption studies in the past already indicated, the genetic heritability in blood pressure resemblances is substantial: between 25 $65 \%$. Pickering and Platt debated in the 1960 s the distribution of blood pressure in the population. While Pickering argued that blood pressure like other traits such as height or weight is continuously distributed, Platt believed that the distribution was bimodal. Nowadays, the polygenic model of Pickering has been widely accepted as the best model explaining the blood pressure distribution. The major gene that should explain the bimodal distribution of blood pressure in Platt's model seems not to exist; instead, the evidence is growing that multiple genes are involved each having a modest effect on blood pressure. Although the genetic component of blood pressure heritability is substantial, environmental factors cannot be ruled out. The actual blood pressure of a subject is the resultant of a very complex play between many genetic, environmental and interacting factors. To understand the contemporary epidemic outbreak of hypertension in the developed and developing world, some evolutionary aspects of blood pressure regulation need to be emphasized. Several studies indicate that our entire world 
population is belonging to a small sub-Saharan African founding population that replaced all other hominoids. This implies that there is substantial sharing of alleles, including those responsible for common diseases. It has been hypothesized that until the industrialization, that dramatically changed our way of living with regard to physical activity and dietary patterns, there was no evolutionary selection pressure to adapt our genes. Due to the irregular availability of food, short periods of feast alternated with relatively longer periods of hunger. These circumstances selected thrifty genes in our African founders. The thrifty-genotype hypothesis implies that the genetic basis of contemporary modern diseases such as obesity, hypertension and diabetes mellitus is not to be found in recent mutations or genetic defects, but rather lies in the conservation of the ancestral version of the relevant genes.

Three different approaches for the study of genetics in hypertension are practiced: studies on rare genetic syndromes, linkage studies and association studies. In the last years, most progress in the study of genetic aspects of hypertension has been made by meticulously studying the several monogenic or Mendelian forms of hypertension. Almost all syndromes (glucocorticoid-remediable aldosteronism, apparent mineralocorticoid excess, hypertension exacerbated in pregnancy, Liddle syndrome, pseudohypoaldosteronism type II) have been clarified at the molecular level. Not surprisingly, in all these syndromes the molecular defect is causing an increased sodium and volume reabsorption, thereby again illustrating the importance of the kidney in the pathophysiology of hypertension. Only one monogenic syndrome, hypertension with brachydactyly, still has to be clarified.

Although the genes involved in these syndromes typically impart very large effects on blood pressure, the genes involved in essential hypertension mostly show modest effects. The extensive search for these genes revealed linkages with quantitative trait loci on almost all chromosomes. Especially chromosomes 2, 3, and 7 repeatedly showed evidence for linkage with hypertension. Candidate genes that showed significant linkage are AGT, $\alpha$-adducin, ACE, and AT1R. The M235T polymorphism in AGT, insertion/deletion (I/D) polymorphism in ACE, and A1166C polymorphism in AT1R frequently showed positive associations with hypertension, although opposite associations have been reported as well.

Finally, this chapter gives an overview of the RAS as we know it today. Briefly, by cleaving AGT renin generates angiotensin I (Angl), which is then converted by ACE to Angll. This effector hormone Angll, by stimulating the AT1R, produces amongst others vasoconstriction, sodium retention, and stimulation of cellular proliferation. It is now becoming more clear that besides the circulating RAS, tissue RAS is at least as important in Angll generation. Furthermore, new angiotensins (AngIII and AngIV) and new receptors (AT2R and AT4R) have been discovered, although the exact functions of these new team players are not yet completely understood. 


\section{RAS polymorphisms and blood pressure}

Taking the obvervations into account described above, we decided to focus on the role of the ACE I/D and AT1R A1166C polymorphisms in modulating the effects of Angll on the kidney and, indirectly, blood pressure.

In chapter $\mathbf{3}$ the results are described of a study in healthy normotensives in which we investigated the associations of the ACE I/D and AT1R A1166C polymorphisms with blood pressure. The rationale of this study was that most data with regard to the potential hypertensive effect of genetic polymorphisms, alone or in combination, have been obtained in selected populations, which are potentially confounded by referral bias. Furthermore, in most studies dealing with the effect of genetic polymorphisms on blood pressure, results may have been influenced by pre-existing cardiovascular morbidity and antihypertensive treatment. Therefore, the present study aimed to assess the effect of the two aforementioned polymorphisms and their interaction on blood pressure in healthy normotensive subjects who were drawn from a primary care practice. This cross-sectional study included 198 healthy subjects. To minimize blood pressure variability just one investigator measured blood pressure in a standardized way. It was found that the ACE D allele was associated with increased systolic blood pressure (SBP) and diastolic blood pressure (DBP). SBP (but not DBP) was highest in the CC genotype group of the AT1R A1166C polymorphism. No synergistic effect of the ACE D and AT1R C alleles on blood pressure was found. This study thus confirmed an association of the ACE I/D and AT1R A1166C polymorphisms with blood pressure, although a synergistic effect of both polymorphisms on blood pressure does not seem to be present.

In chapter 4 we addressed the same issue as discussed in chapter 3, but now we focused at a highly selected hypertensive population. We hypothesized that data concerning the associations of the ACE I/D and AT1R A1166C polymorphisms with hypertension are conflicting because most studies investigated the qualitative phenotype (hypertension), rather than the quantitative phenotype (the level of blood pressure). Furthermore, most studies have focused on office blood pressures only. We therefore studied both office and 24 blood pressure profiles in 348 hypertensive patients. Office blood pressure did not differ between the various ACE or AT1R genotype groups. However, ambulatory blood pressure (systolic, diastolic, and mean) and blood pressure load were increased in ACE D allele carriers. The AT1R A1166C polymorphism showed no consistent association with blood pressure or blood pressure load. We concluded that frequent measuring of blood pressure by means of ABPM is crucial to find an association of the ACE D allele with various aspects of blood pressure.

Are chapter 3 and 4 examples of two of the many association studies that we saw the last decade in the genetic research in hypertension? We think not, but let us 
first set out the problems that are seen in genetic association studies in complex diseases like essential hypertension.

The first results of new associations usually show positive findings with impressive figures. For instance, the initial data with respect to the association between the ACE I/D polymorphism and myocardial infarction showed odds ratios $>3.0$ (with wide confidence intervals) ${ }^{2}$, whereas a meta-analysis later indicated that it is probably more around $1.5 .^{3}$ Findings in these mostly small studies were often not replicated in larger, better designed studies. This has led to considerable scepticism against association studies. This, in our view, is only partly justifiable. Of course, studies need to be adequately powered to find positive (or negative) associations. In fact, a power calculation published in the manuscripts should help the reader interpret the results. Larger studies that followed at a later stage, mostly rejected earlier reported positive findings. 4.5 These mega-studies, with sometimes $>10,000$ patients included, have one big disadvantage: due to their sizes they only are able to study associations with end-points (death, myocardial infarction, etc.). However, in the complex diseases that are studied it is somewhat illogical to study these 'distal phenotypes'. Many interacting factors between gene and end-point cloud the true genetic effects. Thus, our message is rather to study associations between genetic polymorphisms and intermediate phenotypes (e.g. renal plasma flow, immediate responses to pharmacological agents, etc.) in adequately powered studies. In such studies, large sample sizes usually are not necessary.

The functional aspect of a gene variant is perhaps the most important issue, and certainly the most underappreciated one, of association studies. The question is whether or not a certain polymorphism a) may alter the transcription, translation, composition or function of the gene product, or the regulation of these processes, and b) may do so in a manner that could plausibly be related to the phenotype (i.e. the disease or symptom) that it is associated with. Gambaro et al. have highlighted the example of the ACE I/D polymorphism which has been associated with dozens of the most complex phenotypes imaginable, whereas only a few studies have investigated whether or not the polymorphism is related to altered conversion of Angl to Angll. ${ }^{6}$ As genotyping nowadays is quite easy and cheap to execute, there is a real risk that many association studies will be performed which explore genotype frequencies in data sets (available from earlier studies) with multiple insufficiently defined phenotypes. The chance of finding spurious associations is substantial when many phenotypes are included in such studies. Thus, an association study should only be performed when a clear a priori hypothesis has been formulated.

Although it looks trivial, more attention should be paid to the type of phenotype that will be studied, as well as the quality of phenotyping. The many association studies in essential hypertension deal with either hypertension as a phenotype, which is a dichotomous variable, or blood pressure as a phenotype, which is a 
continuous trait. As probably many genes influence blood pressure over the whole continuum, it seems wise to use only blood pressure as the phenotype to study. With respect to the quality of phenotyping, most studies used office blood pressure measurements. Although easy to perform, there is no doubt anymore that this way of measuring blood pressure has some major shortcomings compared to e.g. ambulatory blood pressure measurements: substantial intra- and interobserver variability, digit preference and observer bias, and the possible white-coat effect. ${ }^{7}$ In a complex disease like essential hypertension the genetic heritability is rather low, ${ }^{8}$ meaning that differences between the wild-type and mutant allele, if associated, will only be a few $\mathrm{mmHg}$. So, investigators studying the association of a certain polymorphism with hypertension should decide to a) study large populations with rather easy-to-perform phenotyping of moderate quality (e.g. office blood pressure measurements by just a few investigators), or b) study smaller populations with high quality phenotyping (e.g. ambulatory blood pressure measurements). The sizes of the populations studied depend on statistical power calculations.

The association of the ACE I/D polymorphism with hypertension varies between different populations. The general idea is that a positive association with a certain phenotype should be reproducible in a different ethnic population (i.e. on a different genetic background) to confirm that the genotype-phenotype relationship really exists. However, we should realize that a certain polymorphism can be associated with a particular phenotype in one ethnic population but not in another. It is not likely that hypertension is a disorder to which the same genes contribute in every population. Analogous to this is the finding that people from recent African descent (Afro-Americans, Carribbeans) more often show a saltsensitive type of hypertension, compared to Caucasians. Different genes may predispose to the phenotype of hypertension in different populations. The key point is that the finding of an association between genotype and phenotype is generally strengthened if the association under investigation can be reproduced in a second sample with a different ethnic background, but that it is not necessarily weakened if the association cannot be confirmed.

Sharma and Jeunemaitre recently proposed clear, stringent criteria for highquality positive and negative association studies that, when adhered to, will greatly enhance the quality of future studies. ${ }^{9}$ The association studies as described in chapter 3 and 4 had clear a priori hypotheses, were well-powered for their study goals, used office blood pressure measurements by one investigator in the normotensive study group and ambulatory blood pressure measurements in the hypertensive study groups, and focused at a quantitative rather than a qualitative trait.

So what to decide about the association of the ACE I/D polymorphism and blood pressure? In general, we may conclude that studies in different populations give divergent results. The clearest association of the ACE I/D polymorphism with 
blood pressure is repeatedly found in African populations or those of recent African descent. In Caucasian and to a lesser extent Asian populations the association is weaker, and predominantly present in males, as our study also showed.

\section{ACE I/D polymorphism and Angll generation}

Although there is now substantial evidence available for a positive association of the ACE I/D polymorphism with blood pressure and, mainly, atherosclerotic complications, it is still unknown whether higher circulating ACE levels in D allele carriers of the ACE I/D polymorphism lead to enhanced formation of Angll. Therefore, we conducted an in vitro study, described in chapter 5, in which the plasmatic conversion of Angl over time in relation to the ACE I/D polymorphism was investigated. The results show that the ACE DD genotype, at least at low plasma concentrations of Angl, is associated with a slower conversion of this peptide, compared to the II and ID genotype groups. Adding an extra amount of Angl to the plasma, however, abolishes the differences between the genotype groups.

We know from phylogenic molecular biology that the absence (i.e. 'deletion') of the Alu element in the human genome is the ancestral state, whereas the presence (i.e. 'insertion') of the Alu element at a particular chromosomal site reflects a single, unique event in human evolution. Once inserted at specific chromosomal locations most Alu elements do not appear to be subject to loss or rearrangement, making them stable genetic markers. ${ }^{10}$ This means that the ACE DD genotype, with the highest serum ACE levels, represents the ancestral situation. As chimpanzee, the last hominoid that diverged from man, are lacking the Alu element the insertion in the ACE gene occurred at most about 7 million years ago." This finding fits well with the fact that people from (recent) African descent have the highest frequency of $D$ alleles, ${ }^{12}$ wheras Asian people (that are most distinct from our African ancestors) have the lowest frequency. ${ }^{13}$

We can only speculate why during evolution of man serum ACE levels had to be lowered. Originally, the RAS is a volume-regulating, rather than a pressureregulating system. Therefore, one could hypothesize that in the ancestral situation thrifty genes were necessary to retain volume and salt in times where continous supply of these essentials was not possible. A slower Angl-II conversion, as we saw in DD subjects, fits in this theoretical framework because slower Angl-II conversion provides for longer duration of salt-retaining effects via Angll and aldosterone. These volume- and salt-retaining mechanisms may have resulted in somewhat higher blood pressures. But as we concluded before, the blood pressure increasing effects of the DD genotype are just minor. During evolution the volume-dependency became less important due to cultivation of man which 
guaranteed a more continous supply of volume and salt. In this way pressureregulating systems probably became more important and the RAS had to be set to a lower level. One way of doing so could have been to reduce serum (and tissue?) ACE levels. In a salt-rich environment as we are faced with today, disposal of sodium becomes much more important than retention of this electrolyte. In this theory, one could envisage that under conditions where sodium intake greatly exceeds the physiological needs or where the renal excretory capacity of the kidney is impaired, other mechanisms have to be recruited to get rid of the surplus. This could be, for instance, a rise in pressure. Thus, salt-sensitivity of blood pressure may not be a disorder in its own right but rather an adaptive phenomenon, necessary to maintain sodium balance. In this theory, salt-related increases in pressure would be more likely to occur in II subjects because they are probably operating at a lower setpoint. In the literature, there is indeed some evidence that salt sensitivity is associated with the ACE I allele. ${ }^{14,15}$

As our study focused only on circulating ACE, we do not know whether the Angl-II conversion by vascular- and tissue-ACE is also slower in DD subjects. Theoretically, it could even be that a higher circulating ACE compensates for decreased vascularand/or tissue Angl-II conversion.

\section{RAS polymorphisms and renal function}

As described earlier, the RAS plays a prominent role in the regulation of renal function. In chapter 6, we describe our study of renal function in 212 well characterized essential hypertensives with respect to the ACE I/D and AT1R A1166C polymorphisms. The results show that the AT1R C allele is independently associated with reduced effective renal plasma flow (ERPF) and glomerular filtration rate (GFR), and increased filtration fraction (FF). No significant interactions between the AT1R C allele and known determinants of renal function (age, gender, body mass index, blood pressure) were present. On the other hand, no differences in renal hemodynamics with respect to the ACE I/D polymorphism were found. Lastly, interactions of the AT1R C and ACE D alleles such as the ones which have previously been reported could not be confirmed for the phenotypes studied here. Thus, our findings show that the AT1R C allele is a new, unknown, independent determinant of renal function.

\section{AT1R A1166C polymorphism and Angll sensitivity}

As the results of chapter 6 indicate that the Angll related effects are more prominent in AT1R C allele carriers, we then decided to test the hypothesis that this polymorphism is associated with increased Angll sensitivity. To this end we 
studied renal hemodynamic and humoral responses to Angll in essential hypertensive patients during a high sodium diet, as in these circumstances the effects of exogeneous Angll are most prominent. Our data, described in chapter 7, show that patients with the AT1R CC genotype display an exaggerated response of GFR, ERPF and renal vascular resistance to Angll at a low dose of 0.3 $\mathrm{ng} / \mathrm{kg} / \mathrm{min}$, but not at the higher doses employed. In addition, we found that CC patients, in contrast to the others, respond to Angll with an overall decrease in heart rate. Thus, except for the changes in heart rate, phenotypic differences between the groups were observed only at the lowest dose when plasma levels of Angll remain within the physiological range. Because responses to Angll during the supraphysiological doses of 1.0 and $3.0 \mathrm{ng} / \mathrm{kg} / \mathrm{min}$ were comparable between the genotype groups, our data indicate that sensitivity, but not reactivity to Angll is increased in CC patients. These findings are in line with observations by others showing increased vascular responsiveness of coronary and internal mammarian arteries, to different stimuli in patients carrying the $C$ allele.

In the following studies, described in chapters 8 and 9, we were interested whether the increased Angll sensitivity in AT1R C allele carriers also has clinical implications with respect to pharmacotherapy. In chapter $\mathbf{8}$ we describe a study in which we investigated the systemic and renal hemodynamic, as well as humoral responses to acute AT1R blockade with the active metabolite of losartan (EXP3174) in relation to the AT1R A1166C polymorphism in essential hypertensives. Patients were examined during both a low and high sodium diet in order to allow evaluation of responses at different levels of activity of the RAS. We found that blood pressure responses to EXP3174 during low and high salt diet were significantly blunted in CC patients compared to AA patients. During low salt both the increase in ERPF and the decrease in FF were significantly blunted as well in CC patients compared to AA patients. These findings indicate that, at least in the acute setting, AT1R blockade is less efficient in AT1R CC patients.

The data presented in chapter 8 raised the question whether these findings can be extrapolated to the daily clinical situation. This prompted us to evaluate the blood pressure responses to chronic AT1R blockade with losartan-based therapy during a trial of 12 weeks duration in patients with the AA and CC genotype of the A1166C polymorphism. The results, laid down in chapter 9, showed that comparable changes in drug regimen were needed to reach office blood pressure goals (SBP $\leq 140 \mathrm{mmHg}$ and DBP $\leq 90 \mathrm{mmHg}$ ). During these 12 weeks all patients showed a significant decrease $(\approx 15-20 \%)$ in office SBP and DBP, which was not significantly different between the genotype groups. With respect to ambulatory blood pressures a significant difference in the fall of daytime blood pressures (SBP, DBP, and mean blood pressure) was found between the genotype groups with a blunted response in CC patients at week 12 . These findings are completely in line with our study on the effects of acute AT1R blockade. 
The results presented in chapter 8 and 9 show a blunted effect of AT1R blockade by losartan in AT1R C allele carriers. This finding is supported by a study of Diez et al. ${ }^{16}$ They showed that left ventricular chamber stiffness remained unchanged in AT1R C allele carriers after 1 year treatment with losartan, whereas it decreased in AA hypertensives.

Evidence is now accumulating that the $C$ allele of the AT1R A1166C polymorphism is an independent cardiovascular risk factor. ${ }^{17-19}$ But it still remains unclear how this epidemiological finding can be explained in a pathophysiological way. As Angll is the effector hormone of the RAS one could hypothesize that higher plasma Angll, increased sensitivity for Angll by the AT1R, or increased density of the AT1R are possible explanations. Then, how are one (or more) of these functional alterations linked with this genetic noncoding mutation? Is the A1166C polymorphism in linkage disequilibrium with a coding mutation nearby or in the promoter? We will discuss each of these possibilities.

We (chapter 8 ) and others ${ }^{20}$ showed that plasma Angll levels are not significantly different between the genotype groups. Whether this is the same at the tissue level is unknown. As is seen often in negative feedback systems (chronic) increases of one component will lead to decreases of its controlling components, thereby ultimately resetting the system. In our study, as described in chapter 8 , no differences as well in renin levels between AA and CC patients could be found. This is confirmed in the study of Miller et al. ${ }^{20}$ So, from these data we should conclude that the enhanced Angll related effects in C allele carriers cannot be explained by increased plasma levels of one of the RAS components.

As we showed in chapter 7 the AT1R A1166C polymorphism is associated with increased Angll sensitivity, but not reactivity. This was predominantly found in the renal vascular bed, although the decrease in heart rate suggests that a partly systemic response is present as well. Others showed increased vascular responsiveness of coronary and internal mammarian arteries to different vasoconstrictor stimuli, including Angll, in patients carrying the C allele. ${ }^{21-23}$ One study demonstrated an increased vascular sensitivity of isolated mesenteric arteries of $C$ allele carriers to prostaglandin $\mathrm{F}$ (2alpha), but not to angiotensins. ${ }^{24}$ Hilgers et al. did not find differences in Angll response with respect to the AT1R A1166C polymorphism. ${ }^{25}$ The discrepancies of this study with our findings could be explained by the short-term infusion of relatively high Angll doses ( 0.5 and 1.0 $\mathrm{ng} / \mathrm{kg} / \mathrm{min}$ for 15 minutes). As this evidence clearly indicates that increased Angll sensitivity is associated with the AT1R A1166C polymorphism, the exact pathophysiological mechanism remains unclear. Is the AT1R itself more sensitive for its agonist, or are the number of AT1Rs upregulated in C allele carriers? To answer these questions AT1R binding studies are useful.

Although, it is difficult to study in vivo AT1R density, ex vivo platelet binding studies are an accepted model. ${ }^{26-28}$ As we describe in chapter 8 , and confirmed by Paillard et al., ${ }^{29}$ no differences in the number of platelet AT1R binding sites ( $\left.B_{\max }\right)$ 
between AA and CC patients are present. These findings are compatible with the equal plasma levels of Angll that are found, as described above. Indirect evidence further indicates that the number of AT1Rs indeed is not upregulated in carriers with the CC genotype, as the increased responsiveness to Angll is not masked by the increase in AT1Rs due to ACE inhibition. ${ }^{23}$ This is of interest because it provides the hypothesis that CC patients may still increase their response to Angll, even under circumstances that by themselves cause increased Angll responsiveness. As these data suggest that not the number of AT1Rs is increased in C allele carriers, we hypothesize that the explanation lies in an increased Angll sensitivity of the AT1R itself. However, the same platelet AT1R binding studies as described above, could not show differences in Angll affinity $\left(K_{D}\right)$ of the AT1R. Although we should conclude from the platelet binding data that the number and function of the AT1R is comparable between the genotype groups, one should realize that this model is just a surrogate model for the systemic RAS, as well as for the local RAS in the kidneys and adrenals. The AT1R probably is not an important receptor for the platelet, as is illustrated by the low number of AT1Rs ${ }^{29-31}$ per platelet (about 4 to 6). So, although this is the best tool we have to estimate in vivo AT1R density and Angll affinity we should be careful by extrapolating findings to the systemic and local RAS. Our AT1R blockade data (chapters 8 and 9) further support the hypothesis of an increased agonist responsiveness of the AT1R in C allele carriers. The AT1R antagonist losartan is less effective in blocking the receptor due to the increased agonist-ligand interaction in C allele carriers compared to A allele carriers.

The AT1R A1166C polymorphism is located in the 3'-untranslated region (3'-UTR) of the gene. In this part of a gene mRNA stability is regulated. It is hypothesized that these regions play a role in changing gene expression in cardiovascular pathophysiology. ${ }^{32}$ The binding of AUF1, a protein that affects AT1R mRNA stability through binding to AU-rich regions of the $3^{\prime}-U T R$, is not affected by this polymorphism. ${ }^{33}$ Newly identified polymorphisms in the AT1R gene that might explain the associations found with the $C$ allele are particularly worthwhile for further characterization when 3 conditions are met: linkage disequilibrium with the AT1R A1166C polymorphism, a similar or stronger interaction with the disease, and location in a region that would suggest a functional role. As the promoter of a gene is important in gene function regulation, several studies searched for new polymorphisms in the promoter of the AT1R gene. Several new polymorphisms have been found, mostly in linkage disequilibrium with each other, but not with the A1166C polymorphism in the $3^{\prime}-$ UTR. $^{34,35}$ One study showed a weak linkage disequilibrium between the mutant $A$ allele of the G-2228A promoter polymorphism and the mutant $\mathrm{C}$ allele of the $\mathrm{A} 1166 \mathrm{C}$ polymorphism. ${ }^{36}$ However, in this study no association of any of the alleles with hypertension could be found. To conclude, the noncoding AT1R A1166C polymorphism is an independent cardiovascular risk factor. (In)direct evidence indicates that increased levels of 
renin and Angll or upregulated AT1Rs in C allele carriers are probably not the pathophysiological explanation. The more logical explanation is a functionally altered AT1R, leading to an increased Angll responsiveness. However, the hard evidence is still lacking. At the molecular level, no new coding polymorphisms have been found yet that are in complete linkage disequilibrium with the $\mathrm{A} 1166 \mathrm{C}$ polymorphism, nor is the mutant $C$ allele of this polymorphism associated with an altered AT1R mRNA stability.

\section{Perspectives for future research}

Although essential hypertension is the most important risk factor worldwide for mortality, our knowledge of its pathophysiology is just poor. The genetic component in essential hypertension is substantial, and so are probably the number of genes that are involved. Association studies will be needed for discovering new potential candidate genes. Each of these genes have small effects (just a few $\mathrm{mmHg}$ ) on blood pressure in the general population, making the quality criteria of the study designs very important. If studies adhere to these stringent criteria, their results, both positive and negative (!), are useful for our understanding of the pathophysiology of essential hypertension. Nowadays, most association studies focus on one or just a few polymorphisms with respect to hypertension. Future association studies will focus on the combination of multiple polymorphisms. These studies need inclusion of thousands of subjects. As discussed above, the quality of phenotyping in such large studies is potentially at risk. The quality and quantity of genotyping is already improving at high speed with the introduction of micro-array facilities. The information that will be gained in this way (multiple genotypes of multiple phenotypes in thousands of patients) will be enormous and hard to decipher. This work will be the field of bioinformatics, a new scientific branch that will show a rapid grow in the next coming years. As large studies are needed for future association studies, international cooperation between research groups seems a logic development. This, however, may introduce a decrease in homogeneity of the study population, and therefore may lead to false negative conclusions. Associations of polymorphisms with blood pressure are not, as we have recently learned, present in all different populations. So, as nowadays essential hypertension is not exclusively a risk factor for mortality in the Western world, genetic studies in other populations are also important as well. The last decade association studies mainly focussed at the distal phenotype hypertension or blood pressure. Future studies will focus more at intermediate phenotypes as RAS activity, sympathetic nerve activity, endothelial function, etc. As these are more proximal phenotypes, smaller study populations can be used. 
Besides bioinformatics, some other rather new sciences will be 'booming' the coming years and will be important for a complete understanding of the (patho)physiology from gene to blood pressure. Genes are translated to proteins, which eventually will cause an effect, eg. rise in blood pressure. This is the field of proteomics: identifying and quantifying these proteins, and determine their localization, modifications, interactions, activities, and, ultimately, their function. Understanding the exact route from genotype to phenotype creates potential levels of pharmacological intervention, thereby modifying the phenotype. Lastly, the area of pharmacogenetics, in which the responses to pharmacotherapy with respect to genetic determinants are studied, will learn us more about the interindividual differences in blood pressure responses to antihypertensives.

The first steps in understanding the complex mechanisms that are involved in blood pressure regulation have been made. Many more more steps will follow the coming years. 


\section{References}

1. Ezzati M, Lopez AD, Rodgers A, Vander Hoorn S, Murray CI. Selected major risk factors and global and regional burden of disease. Lancet 2002;360:1347-60.

2. Tiret L, Bonnardeaux A, Poirier O, Ricard S, Marques-Vidal P, Evans A, Arveiler D, Luc G, Kee F, Ducimetiere P, et al. Synergistic effects of angiotensin-converting enzyme and angiotensin-II type 1 receptor gene polymorphisms on risk of myocardial infarction. Lancet 1994;344:910-3.

3. Staessen JA, Wang JG, Ginocchio G, Petrov V, Saavedra AP, Soubrier F, Vlietinck R, Fagard R. The deletion/insertion polymorphism of the angiotensin converting enzyme gene and cardiovascular-renal risk. J Hypertens 1997;15:1579-92.

4. Agerholm-Larsen B, Nordestgaard BG, Steffensen R, Sorensen T, Jensen G, Tybjaerg-Hansen A. ACE gene polymorphism: ischemic heart disease and longevity in 10,150 individuals. A casereferent and retrospective cohort study based on the Copenhagen City Heart Study. Circulation 1997;95:2358-67.

5. Keavney B, McKenzie C, Parish S, Palmer A, Clark S, Youngman L, Delepine M, Lathrop M, Peto R, Collins R. Large-scale test of hypothesised associations between the angiotensin-convertingenzyme insertion/deletion polymorphism and myocardial infarction in about 5000 cases and 6000 controls. International Studies of Infarct Survival (ISIS) Collaborators. Lancet 2000;355:434-42.

6. Gambaro G, Anglani F, D'Angelo A. Association studies of genetic polymorphisms and complex disease. Lancet 2000;355:308-11.

7. Staessen JA, Wang J, Bianchi G, Birkenhager WH. Essential hypertension. Lancet 2003;361: 1629-41.

8. Lander ES, Schork NJ. Genetic dissection of complex traits. Science 1994;265:2037-48.

9. Sharma AM, Jeunemaitre $X$. The future of genetic association studies in hypertension: improving the signal-to-noise ratio. $J$ Hypertens 2000;18:811-4.

10. Batzer MA, Stoneking M, Alegria-Hartman M, Bazan H, Kass DH, Shaikh TH, Novick GE, loannou PA, Scheer WD, Herrera RJ, et al. African origin of human-specific polymorphic Alu insertions. Proc Natl Acad SciU S A 1994;91:12288-92.

11. Sibley CG, Ahlquist JE. The phylogeny of the hominoid primates, as indicated by DNA-DNA hybridization. J Mol Evol 1984;20:2-15.

12. Rotimi C, Puras A, Cooper R, McFarlane-Anderson N, Forrester T, Ogunbiyi O, Morrison L, Ward R. Polymorphisms of renin-angiotensin genes among Nigerians, Jamaicans, and African Americans. Hypertension 1996;27:558-63.

13. Harrap SB, Tzourio C, Cambien F, Poirier O, Raoux S, Chalmers J, Chapman N, Colman S, Leguennec S, MacMahon S, Neal B, Ohkubo T, Woodward M. The ACE gene I/D polymorphism is not associated with the blood pressure and cardiovascular benefits of ACE inhibition. Hypertension 2003;42:297-303.

14. Poch E, Gonzalez D, Giner V, Bragulat E, Coca A, de La Sierra A. Molecular basis of salt sensitivity in human hypertension. Evaluation of renin-angiotensin-aldosterone system gene polymorphisms. Hypertension 2001;38:1204-9.

15. Hiraga $H$, Oshima T, Watanabe $M$, Ishida $M$, Ishida $T$, Shingu $T$, Kambe $M$, Matsuura $H$, Kajiyama G. Angiotensin I-converting enzyme gene polymorphism and salt sensitivity in essential hypertension. Hypertension 1996;27:569-72.

16. Diez J, Laviades C, Orbe J, Zalba G, Lopez B, Gonzalez A, Mayor G, Paramo JA, Beloqui O. The A 1166C polymorphism of the AT1 receptor gene is associated with collagen type I synthesis and myocardial stiffness in hypertensives. J Hypertens 2003;21:2085-92.

17. Ye S, Dhillon S, Seear R, Dunleavey L, Day LB, Bannister W, Day IN, Simpson I. Epistatic interaction between variations in the angiotensin I converting enzyme and angiotensin II type 1 receptor genes in relation to extent of coronary atherosclerosis. Heart 2003;89:1195-9. 
18. Coll E, Campos B, Gonzalez-Nunez D, Botey A, Poch E. Association between the A1166C polymorphism of the angiotensin II receptor type 1 and progression of chronic renal insufficiency. J Nephrol 2003;16:357-64.

19. Jones A, Dhamrait SS, Payne JR, Hawe E, Li P, Toor IS, Luong L, Wootton PT, Miller GJ, Humphries SE, Montgomery HE. Genetic variants of angiotensin II receptors and cardiovascular risk in hypertension. Hypertension 2003;42:500-6.

20. Miller JA, Thai K, Scholey JW. Angiotensin II type 1 receptor gene polymorphism predicts response to losartan and angiotensin II. Kidney Int 1999;56:2173-80.

21. Amant C, Hamon M, Bauters C, Richard F, Helbecque N, McFadden EP, Escudero X, Lablanche JM, Amouyel P, Bertrand ME. The angiotensin II type 1 receptor gene polymorphism is associated with coronary artery vasoconstriction. JAm Coll Cardiol 1997;29:486-90.

22. Henrion D, Amant C, Benessiano J, Philip I, Plantefeve G, Chatel D, Hwas U, Desmont JM, Durand G, Amouyel P, Levy BI. Angiotensin II type 1 receptor gene polymorphism is associated with an increased vascular reactivity in the human mammary artery in vitro. JVasc Res 1998;35:356-62.

23. van Geel PP, Pinto YM, Voors AA, Buikema H, Oosterga M, Crijns HJ, van Gilst WH. Angiotensin II type 1 receptor $A 1166 C$ gene polymorphism is associated with an increased response to angiotensin II in human arteries. Hypertension 2000;35:717-21.

24. Steeds RP, Toole LO, Channer KS, Morice AH. Human vascular reactivity and polymorphisms of the angiotensin-converting enzyme and the angiotensin type 1 receptor genes. $J$ Vasc Res 1999;36:445-55; discussion 535-8.

25. Hilgers KF, Langenfeld MR, Schlaich M, Veelken R, Schmieder RE. 1166 A/C polymorphism of the angiotensin II type 1 receptor gene and the response to short-term infusion of angiotensin II. Circulation 1999;100:1394-9.

26. Ding YA, Kenyon CJ, Semple PF. Receptors for angiotensin II on platelets from man. Clin Sci (Lond) 1984;66:725-31.

27. Duggan J, Kilfeather S, O'Brien E, O'Malley K, Nussberger J. Effects of aging and hypertension on plasma angiotensin II and platelet angiotensin II receptor density. Am J Hypertens 1992;5:687-93.

28. Pouliot L, Forest JC, Moutquin JM, Coulombe N, Masse J. Platelet angiotensin II binding sites and early detection of preeclampsia. Obstet Gynecol 1998;91:591-5.

29. Paillard F, Chansel D, Brand E, Benetos A, Thomas F, Czekalski S, Ardaillou R, Soubrier F. Genotype-phenotype relationships for the renin-angiotensin-aldosterone system in a normal population. Hypertension 1999;34:423-9.

30. Makarious M, Pawlak M, Campbell LV, Timmermans V, Duggan K, Charlesworth JA, Macdonald GJ. The platelet angiotensin II receptor in type I diabetes: studies in patients with and without nephropathy. Eur J Clin Invest 1993;23:517-21.

31. Mann JF, Sis J, Ritz E. 125I-Angiotensin II binding to human blood cells. J Hypertens 1985;3:131-7.

32. Misquitta CM, lyer VR, Werstiuk ES, Grover AK. The role of 3'-untranslated region (3'-UTR) mediated mRNA stability in cardiovascular pathophysiology. Mol Cell Biochem 2001;224:53-67.

33. Pende A, Giacche M, Castigliola L, Contini L, Passerone G, Patrone M, Port JD, Lotti G. Characterization of the binding of the RNA-binding protein AUF1 to the human AT(1) receptor mRNA. Biochem Biophys Res Commun 1999;266:609-14.

34. Poirier O, Georges JL, Ricard S, Arveiler D, Ruidavets JB, Luc G, Evans A, Cambien F, Tiret L. New polymorphisms of the angiotensin II type 1 receptor gene and their associations with myocardial infarction and blood pressure: the ECTIM study. Etude Cas-Temoin de I'Infarctus du Myocarde. J Hypertens 1998;16:1443-7.

35. Erdmann J, Riedel K, Rohde K, Folgmann I, Wienker T, Fleck E, Regitz-Zagrosek V. Characterization of polymorphisms in the promoter of the human angiotensin II subtype 1 (AT1) receptor gene. Ann Hum Genet 1999;63:369-74.

36. Zhang X, Erdmann J, Regitz-Zagrosek V, Kurzinger S, Hense HW, Schunkert H. Evaluation of three polymorphisms in the promoter region of the angiotensin II type I receptor gene. $J$ Hypertens 2000;18:267-72. 
Summary 


\section{Summary}

Essential hypertension is a common disorder, which affects $25-30 \%$ of the adult population, and up to $60-70 \%$ of those beyond the seventh decade of life. Although seemingly symptomless it is in fact a silent killer, because it is by far the most important risk factor worldwide for total mortality. Although the clinical implications of hypertension are substantial our understanding of the disorder is strikingly low. The majority of patients with hypertension $(\approx 95 \%)$ suffers from primary or essential hypertension, which is an euphemism for not knowing the exact cause of the increased pressure. It is widely believed that essential hypertension is a multifactorial disorder caused by heterogeneous genetic and environmental factors.

Accumulating evidence shows that the kidney plays a central role in the pathophysiology of essential hypertension. The renin-angiotensin system (RAS) is the principal hormonal system that modulates both renal hemodynamics, i.e. glomerular filtration rate and renal blood flow, as well as tubular function. Angiotensin II (AngII) is the effector hormone of this system and genes involved in its generation and effect (angiotensinogen (AGT), angiotensin-converting enzyme (ACE), and angiotensin II type 1 receptor (AT1R)) seem to play a prominent role in the genetics of essential hypertension. The mutant $D$ allele of the ACE insertion/deletion (I/D) polymorphism is associated with higher circulating serum ACE levels and therefore, at least in theory, generates more Angll causing higher blood pressures and an increased incidence of cardiovascular disorders. On the other hand, the mutant $C$ allele of the AT1R A1166C polymorphism is associated with a higher incidence of cardiovascular abnormalities and there is data to show that the interaction of Angll with the AT1R is altered due to this polymorphism. Taking these observations into account, our research has focused on the role of these polymorphisms in modulating the effects of Angll on the kidney and, indirectly, blood pressure.

\section{Genetic aspects of hypertension}

Chapter 2 provides an overview of the genetic aspects of both monogenic and essential hypertension. As twin and adoption studies in the past already indicated, the genetic heritability in blood pressure resemblances is substantial: between 25$65 \%$. The evidence is growing that multiple genes are involved each having a modest effect on blood pressure. Although the genetic component of blood pressure heritability is substantial, environmental factors cannot be ruled out. The actual blood pressure of a subject is the resultant of a very complex play between many genetic, environmental and interacting factors. 
Whereas in earlier times hypertension was rarely seen, we are now faced with an epidemic outbreak in the developed and developing world. The thrifty-genotype hypothesis implies that the genetic basis of contemporary modern diseases such as obesity, hypertension and diabetes mellitus is not to be found in recent mutations or genetic defects, but rather lies in the conservation of the ancestral version of the relevant genes. These genes in our contemporary environment of high salt and carbohydrates intake explains the increasing incidence of these diseases.

In the last years, most progress in the study of genetic aspects of hypertension has been made by meticulously studying the several monogenic or Mendelian forms of hypertension. Almost all these monogenic syndromes have been clarified at the molecular level. Not surprisingly, in all these syndromes the molecular defect is causing an increased sodium and volume reabsorption, thereby again illustrating the importance of the kidney in the pathophysiology of hypertension. Although the genes involved in these syndromes typically impart very large effects on blood pressure, the genes involved in essential hypertension mostly show modest effects. The extensive search for these genes revealed linkages with quantitative trait loci on almost all chromosomes. Candidate genes that showed significant linkage are AGT, $\alpha$-adducin, ACE, and AT1R. The M235T polymorphism in AGT, insertion/deletion (I/D) polymorphism in ACE, and $A 1166 C$ polymorphism in AT1R frequently showed positive associations with hypertension, although opposite associations have been reported as well.

\section{RAS polymorphisms and blood pressure}

Taking the obvervations into account described above, we decided to focus on the role of the ACE I/D and AT1R A1166C polymorphisms in modulating the effects of Angll on the kidney and, indirectly, blood pressure.

In chapter $\mathbf{3}$ the results are described of a study in healthy normotensives who were drawn from a primary care practice, in which we investigated the associations of the ACE I/D and AT1R A1166C polymorphisms with blood pressure. It was found that the ACE D allele was associated with increased systolic blood pressure (SBP) and diastolic blood pressure (DBP). SBP (but not DBP) was highest in the CC genotype group of the AT1R A1166C polymorphism. No synergistic effect of the ACE D and ATIR C alleles on blood pressure was found. In chapter 4 we addressed the same issue as discussed in chapter 3 , but now we focused at a highly selected hypertensive population. We hypothesized that data concerning the associations of the ACE I/D and AT1R A1166C polymorphisms with hypertension are conflicting because most studies investigated the qualitative phenotype (hypertension), rather than the quantitative phenotype (the level of blood pressure). Furthermore, most studies have focused on office blood pressures only. We therefore studied both office and 24 blood pressure profiles in 348 hypertensive patients. Office blood pressure did not differ between the 
various ACE or AT1R genotype groups. However, ambulatory blood pressure (systolic, diastolic, and mean) and blood pressure load were increased in ACE D allele carriers. The AT1R A1166C polymorphism showed no consistent association with blood pressure or blood pressure load. We concluded that frequent measuring of blood pressure by means of ambulatory blood pressure measurement is crucial to find an association of the ACE D allele with various aspects of blood pressure.

\section{ACE I/D polymorphism and Angll generation}

Although there is now substantial evidence available for a positive association of the ACE I/D polymorphism with blood pressure and, mainly, atherosclerotic complications, it is still unknown whether higher circulating ACE levels in D allele carriers of the ACE I/D polymorphism lead to enhanced formation of Angll. Therefore, we conducted an in vitro study, described in chapter 5, in which the plasmatic conversion of Angl over time in relation to the ACE I/D polymorphism was investigated. The results show that following the immediate conversion of Angl, a secondary phase of slow conversion is demonstrable. While the initial phase does not differ between the three genotype groups, the slow conversion of Angl does, with the lowest conversion occurring in DD patients. The difference can be overcome at higher prevailing concentrations of Angl.

\section{RAS polymorphisms and renal function}

As described earlier, the RAS plays a prominent role in the regulation of renal function. In chapter 6, we describe our study of renal function in 212 well characterized essential hypertensives with respect to the ACE I/D and AT1R $A 1166 C$ polymorphisms. The results show that the AT1R $C$ allele is independently associated with reduced effective renal plasma flow and glomerular filtration rate, and increased filtration fraction. No significant interactions between the AT1R C allele and known determinants of renal function (age, gender, body mass index, blood pressure) were present. On the other hand, no differences in renal hemodynamics with respect to the ACE I/D polymorphism were found. Lastly, interactions of the AT1R C and ACE D alleles such as the ones which have previously been reported could not be confirmed for the phenotypes studied here. Thus, our findings show that the AT1R C allele is a new, unknown, independent determinant of renal function.

\section{AT1R A1166C polymorphism and Angll sensitivity}

As the results of chapter 6 indicate that the Angll related effects are more prominent in AT1R C allele carriers, we then decided to test the hypothesis that this polymorphism is associated with increased Angll sensitivity. Our data, 
described in chapter 7 , show that the $C$ allele of the AT1R A1166C polymorphism is associated with increased sensitivity, but not reactivity to Angll. In the following studies, described in chapters $\mathbf{8}$ and $\mathbf{9}$, we were interested whether the increased Angll sensitivity in AT1R C allele carriers also has clinical implications with respect to pharmacotherapy. We were able to show a blunted effect of both acute (chapter 8) and chronic (chapter 9) AT1R blockade by losartan in AT1R C allele carriers.

Evidence is now accumulating that the $C$ allele of the AT1R A1166C polymorphism is an independent cardiovascular risk factor. It still remains unclear how this epidemiological finding can be explained in a pathophysiological way. We showed that both plasma renin and Angll levels are not significantly different between the genotype groups. Indirect evidence from platelet binding studies indicated that also number of AT1R binding sites, or an increased Angll sensitivity of the AT1R itself are not plausible explanations.

In chapter $\mathbf{1 0}$ the results of the studies mentioned above are discussed in light of the current literature. Lastly, we discuss the perspectives for future reseach in the field of genetics of hypertension. 
Samenvatting 


\section{Samenvatting}

Essentiële hypertensie (=verhoogde bloeddruk) is een veel voorkomende aandoening, welke bij $25-30 \%$ van de volwassen populatie voorkomt, en zelfs bij $60-70 \%$ van de mensen ouder dan 70 jaar. Alhoewel het een symptoomloze aandoening lijkt te zijn, is het in feite een stille moordenaar, omdat het wereldwijd verreweg de belangrijkste risicofactor is voor totale mortaliteit. Ondanks de klinische implicaties van hypertensie, is ons begrip van deze ziekte opvallend gering. In het merendeel van de patiënten met hypertensie $(\approx 95 \%)$ is sprake van primaire of essentiële hypertensie, wat een eufemisme is voor het niet kennen van de exacte oorzaak. Het wordt algemeen aangenomen dat essentiële hypertensie een multifactoriële aandoening is, veroorzaakt door heterogene genetische en omgevingsfactoren.

$\mathrm{Er}$ is toenemend bewijs dat de nieren een centrale rol spelen in de pathofysiologie van essentiële hypertensie. Het renine-angiotensine systeem (RAS) is het hormonale systeem dat zowel de renale hemodynamiek (glomerulaire filtratiesnelheid en renale doorbloeding), als de tubulaire functie beïnvloedt. Angiotensine II (AngII) is het effector-hormoon van dit systeem en de genen welke betrokken zijn bij zowel de produktie als effecten van dit hormoon (angiotensinogeen (AGT), 'angiotensin-converting enzyme' (ACE), angiotensine ॥ type 1 receptor (AT1R)), lijken een prominente rol te spelen in de genetische aspecten van essentiële hypertensie. Het mutante D-allel van het ACE insertie/deletie (I/D) polymorfisme vertoont een associatie met hogere circulerende serum ACE-waarden en kan derhalve, althans theoretisch, leiden tot een grotere productie van Angll, hetgeen op den duur hogere bloeddrukken en een toegenomen incidentie van cardiovasculaire aandoeningen tot gevolg heeft. Daarnaast is er het mutante C-allel van het AT1R A1166C polymorfisme, hetgeen ook geassocieerd is met een toegenomen incidentie van cardiovasculaire afwijkingen. Het is vooralsnog onduidelijk of de interactie van Angll met de AT1R veranderd is door dit polymorfisme. Dit hiaat in onze kennis vormde de aanleiding voor ons onderzoek: wat is de rol van deze polymorfismen in het moduleren van de effecten van Angll op de nier en, indirect, de bloeddruk.

\section{Genetische aspecten van hypertensie}

Hoofdstuk 2 bevat een overzicht van de genetische aspecten van zowel monogene als essentiële hypertensie. Uit vroegere tweeling-en adoptie-studies is gebleken dat de genetische overerving van bloeddrukovereenkomsten substantieel is: ongeveer $25-65 \%$. Er is toenemend bewijs dat multipele genen hierbij betrokken zijn, met elk slechts een gering effect op de bloeddruk. Hoewel de genetische component bij de overerving van bloeddruk aanzienlijk is, spelen 
omgevingsfactoren ook een grote rol. De eigenlijke bloeddruk van een persoon is de resultante van een complex spel tussen vele genetische, omgevings- en andere factoren. Waar hypertensie in vroegere tijden zelden werd gezien, worden we nu geconfronteerd met een epidemie in zowel de westerse als de ontwikkelingslanden. De 'thrifty-genotype' (=zuinig genotype) hypothese houdt in dat de genetische basis van hedendaagse moderne ziekten, zoals obesitas, hypertensie en diabetes mellitus niet verklaard kan worden door recente mutaties of genetische defecten, maar door de 'conservering' van zogenaamde betrokken oergenen. Verondersteld wordt dat deze genen in onze hedendaagse omgeving met een hoge inname van zout en koolhydraten de oorzaak zijn van een toenemende incidentie van deze ziekten. De afgelopen jaren is de meeste vooruitgang in de studie van genetische aspecten van hypertensie geboekt door het nauwgezet bestuderen van monogene of Mendeliaanse vormen van hypertensie. Bijna alle bekende monogene syndromen zijn inmiddels tot op moleculair niveau opgehelderd. Niet onverwacht, veroorzaken al deze moleculaire defecten een toegenomen zout- en volumereabsorptie, daarbij nogmaals het belang van de nier in de pathofysiologie van hypertensie onderstrepend. Hoewel de genen betrokken bij deze monogene syndromen erg grote effecten op de bloeddruk uitoefenen, hebben de genen die betrokken zijn bij essentiële hypertensie een meestal veel geringer effect. De uitgebreide zoektocht naar deze genen liet koppelingen zien met zogenaamde 'quantitative trait loci' (=genetische locus waarvan wordt aangenomen dat het continu verdeelde kenmerken zoals bloeddruk, cholesterol, etc. bepaald) op bijna alle chromosomen. Kandidaatgenen welke een significante koppeling hebben laten zien met hypertensie zijn AGT, $\alpha$ adducine, ACE, en AT1R. Het M235T polymorfisme bij AGT, insertie/deletie (I/D) polymorfisme bij ACE, en A1166C polymorfisme bij AT1R hebben herhaaldelijk positieve associaties met hypertensie laten zien, alhoewel negatieve associaties ook gerapporteerd zijn.

\section{RAS polymorfismen en bloeddruk}

De waarnemingen, zoals hierboven beschreven, inachtnemend, besloten wij ons te richten op de rol van de ACE I/D en AT1R A1166C polymorfismen in het moduleren van de effecten van Angll op de nier en, indirect, de bloeddruk.

In hoofdstuk 3 worden de resultaten beschreven van een studie in gezonde normotensieven, gerekruteerd uit een huisartsenpraktijk, waarin we de associaties van de ACE I/D en AT1R A 1 166C polymorfismen met bloeddruk onderzochten. Wij vonden dat het ACE D-allel samenhing met een verhoogde systolische en diastolische bloeddruk. Systolische bloeddruk (maar niet diastolische bloeddruk) was het hoogste in de CC-genotype groep van het AT1R A 1166C polymorfisme. Er werd geen synergistisch effect van de ACE D- en AT1R C-allelen op de bloeddruk gevonden. In hoofdstuk $\mathbf{4}$ keken we naar hetzelfde vraagstuk als besproken in hoofdstuk 3, maar nu in een sterk geselecteerde hypertensieve populatie. Wij 
veronderstelden dat onderzoeksresultaten betreffende de associaties van de ACE I/D en AT1R A1166C polymorfismen met hypertensie zo tegenstrijdig zijn, omdat de meeste studies het kwalitatieve fenotype (hypertensie), in plaats van het kwantitatieve fenotype (de hoogte van de bloeddruk) onderzochten. Verder keken de meeste studies naar alleen spreekkamerbloeddrukken. Wij onderzochten derhalve zowel spreekkamer- als 24-uurs ambulante bloeddrukmetingen in 348 hypertensieven. Spreekkamerbloeddrukken verschilden niet tussen de verschillende ACE of AT1R genotype-groepen. Ambulante bloeddrukken (systolisch, diastolisch, en gemiddelde) en bloeddruk-'load' (=percentage van bloeddrukwaarden boven een normaal gemiddelde) waren daarentegen verhoogd in ACE D-allel dragers. Het AT1R A1166C polymorfisme liet geen consistente associatie met bloeddruk of bloeddruk-'load' zien. Wij concludeerden dat herhaaldelijk meten van de bloeddruk, zoals met ambulante 24-uurs metingen, cruciaal is om een associatie van het ACE D-allel met verschillende bloeddrukaspecten te vinden.

\section{ACE I/D polymorfisme en Angll-vorming}

Alhoewel er thans meer bewijs aanwezig is voor een positief verband tussen het ACE I/D polymorfisme en de bloeddruk of atherosclerotische complicaties, is het nog steeds onbekend of hogere circulerende ACE-waarden in D-allel dragers van het ACE I/D polymorfisme tot een toegenomen vorming van Angll leiden. Wij hebben daarom een in vitro studie verricht, beschreven in hoofdstuk 5, waarin de plasma-conversie van Angl gedurende de tijd in relatie tot het ACE I/D polymorfisme bestudeerd werd. De resultaten laten zien dat na een eerste, snelle conversie van Angl, een tweede fase van langzame conversie optreedt. Terwijl de eerste, snelle, fase niet verschillend is tussen de drie genotype-groepen, is de tweede, langzame conversie van Angl dat wel, met de traagste conversie in DDpatiënten. Het verschil kan opgeheven worden door hogere Angl-concentraties aan het begin van de conversie.

\section{RAS polymorfismen en nierfunctie}

Zoals eerder beschreven, speelt het RAS een prominente rol in de regulatie van de nierfunctie. In hoofdstuk 6 beschrijven wij een studie waarin wij gekeken hebben naar de nierfunctie in 212 goed gekarakteriseerde essentieel hypertensieven in relatie tot de ACE I/D en AT1R A1166C polymorfismen. De resultaten laten zien dat het AT1R C-allel onafhankelijk geassocieerd is met een afgenomen doorbloeding en filtratiesnelheid, en een toegenomen filtratiefractie. Er waren geen significante interacties tussen het AT1R C-allel en bekende determinanten van nierfunctie (leeftijd, geslacht, Quetelet-index, bloeddruk). Daarentegen konden geen verschillen in renale hemodynamiek gevonden worden met betrekking tot het ACE I/D polymorfisme. Tenslotte konden geen interacties tussen de AT1R C- en 
ACE D-allelen, zoals die eerder beschreven zijn, gevonden worden voor de fenotypes welke hier bestudeerd zijn. Onze bevindingen laten dus zien dat het AT1R C-allel een nieuwe, nog onbekende, onafhankelijke determinant van de nierfunctie bij hypertensie is.

\section{AT1R A1166C polymorfisme en Angll-gevoeligheid}

Aangezien de resultaten van hoofdstuk 6 lieten zien dat de Angll-gerelateerde effecten prominenter zijn in AT1R C-allel dragers, besloten wij de hypothese te testen dat dit polymorfisme geassocieerd is met een toegenomen Angllgevoeligheid. Onze gegevens, beschreven in hoofdstuk 7, laten zien dat het Callel van het AT1R A1166C polymorfisme geassocieerd is met een toegenomen gevoeligheid, maar niet reactiviteit, voor Angll. In de studies hierna, beschreven in hoofdstukken $\mathbf{8}$ en $\mathbf{9}$, waren wij geïnteresseerd of de toegenomen gevoeligheid voor Angll in AT1R C-allel dragers ook klinische implicaties heeft met betrekking tot farmacotherapie. Wij zagen een afgenomen vermogen in AT1R C-allel dragers de AT1R te blokkeren met losartan, in zowel de acute (hoofdstuk 8 ) als chronische situatie (hoofdstuk 9).

Het bewijs stapelt zich nu op dat het C-allel van de AT1R A1166C polymorfisme een onafhankelijke cardiovasculaire risicofactor is. Het blijft echter nog steeds onduidelijk hoe deze epidemiologische bevinding vanuit pathofysiologisch oogpunt verklaard kan worden. Wij konden aantonen dat zowel plasma-renine en Angll niet significant verschillen tussen de genotype-groepen. Indirect bewijs uit bloedplaatjesbindingstudies toont aan dat ook het aantal AT1R-bindingsplaatsen, of een toegenomen Angll-gevoeligheid van de AT1R zelf, geen plausibele verklaringen zijn.

In hoofdstuk 10 worden de resultaten van de studies zoals hierboven besproken bediscussiëerd in het licht van de huidige literatuur. Tenslotte bediscussiëren wij de perspectieven voor toekomstig onderzoek in het veld van de genetica van hypertensie. 
Dankwoord 


\section{Dankwoord}

En dan het dankwoord. Wetende dat dit het best gelezen onderdeel van het proefschrift zal worden, vergroot dit de druk om niemand te vergeten. Op het moment van schrijven van het dankwoord, heb ik in gedachten alle mensen laten passeren die me al die jaren geholpen hebben. Ik realiseer me nu des te meer dat een promotie-onderzoek echt teamwerk is, wat met de hulp van velen tot stand komt.

Beste Luc Snoeckx, ik begin mijn dankwoord bij jou. Als tweedejaars student kwamen Jos Webers en ik (na een zorgvuldige consultatie van ook andere capaciteitsgroepen) tot de conclusie dat jij de beste persoon was om ons de beginselen van het wetenschappelijk onderzoek bij te brengen. Een artikel en een studentenprijs waren het resultaat. Jouw enthousiasme, maar ook je didactisch talent, hebben toen bij mij de vonk doen overslaan en me laten inzien dat onderzoek leuk en verslavend kan zijn. Dank voor al je tijd en moeite die je in ons gestoken hebt.

Promoveren is niet alleen een paar artikelen schrijven en bundelen in een boekje. Het is ook een opleiding tot wetenschappelijk onderzoeker. Ik mag me gelukkig prijzen dat ik, gesteund door mijn (co)promotor, mijn periode in Maastricht niet alleen met het onderzoek direct gerelateerd aan mijn boekje bezig heb hoeven zijn. Door het mee helpen opzetten van andere onderzoeken, het Cardiovasculair Genotyperingslab en het Cardim-databestand heb ik de diverse facetten van het doen van wetenschappelijk onderzoek kunnen meemaken.

Mijn promotieonderzoek begon met het genotyperen van monsters in het laboratorium van de pathologie onder leiding van Mat Daemen. Beste Mat, aanvankelijk was je nauw betrokken bij het onderzoek, je had het immers samen met Peter opgezet, later liet je me meer en meer los toen je merkte dat één en ander goed op de rails stond. Dank voor je betrokkenheid en aansturing in het begin. Dank ook aan Monique Verluyten die me alle principes van het genotyperen bijbracht en aan de analisten Loes van Eijk en Petra Aarts die veel monsters verwerkt hebben.

Frank Soomers en Jelle Stoffers: klein zijn we begonnen met 2 prikdagen in jullie huisartsenpraktijk in Kerkrade. Dit was het begin van de Kerkrade Risk Study, later omgedoopt tot de Socrates-studie. Goed om te zien dat dit nu is uitgebouwd tot een groot onderzoek waarin op diverse manieren door diverse capaciteitsgroepen gekeken wordt naar de cardiovasculaire aandoeningen in jullie praktijk. Ik ben blij dat de vruchten van dit onderzoek hebben geleid tot een eerste artikel zoals beschreven in hoofdstuk 3 van dit proefschrift. Verder was een aantal van jullie patiënten bereid tot meerdere onderzoeken in Maastricht, die over het algemeen 
veel van hen vroegen. Dank voor jullie hulp hen te selecteren en te vragen om medewerking.

Ik heb mij vrijwel al die jaren wel omringd geweten door één of meerdere studenten die mij geholpen hebben. Allen veel dank daarvoor! Harriet Vreugdenhil: jij was de eerste student en hebt mij mede de principes van werken in een DNA-lab bijgebracht. Het verdere genotyperen is mede gedaan door Vanessa van Empel, Remy Bemelmans en Lisa Tans. Drie studenten hebben veel tijd en moeite gestoken in een onderzoekslijn samen met de Cardiologie: Mireille Emans, Bianca Bendermacher en Ruben de Boer. Ondanks dat de onderzoeken waar jullie mede aan geholpen hebben niet in dit boekje zijn terug te lezen, is jullie inzet zeker niet voor niets geweest. lk heb in ieder geval erg prettig met jullie samengewerkt. Pascal Franssen heeft veel werk verzet in het kader van de ABPMstudie in Rotterdam. Iris Zwaan, de resultaten van je wetenschapsstage hebben mede geleid tot die beschreven in hoofdstuk 4. Dank voor je inzet. En dan Léon Henskens (met een accent aigu boven de e!). Jij was de constante factor de laatste jaren. Je zorgvuldigheid en tomeloze inzet leidden ertoe dat ik, controlfreak als ik soms kan zijn, blind aan jou dingen kon overlaten. Het onderzoek beschreven in hoofdstuk 9 is wel het beste voorbeeld: nagenoeg zelfstandig door jou gedaan. Grote klasse! Alleen jouw voorkeur voor de componistenfamilie Strauss staat diagonaal tegenover die van mij, maar daar valt mee te leven. Ik ben daarom blij dat je eén van mijn paranymfen wilt zijn. $l k$ wens je alle succes toe in je eigen onderzoek.

Diverse onderzoeken heb ik gedaan in samenwerking met collega-onderzoekers. Een onderzoek met de groep van Louis Peeters en Marc Spaanderman van de Gynaecologie en Obstetrie leidde tot interessante bevindingen over de rol van RAS-polymorfismen bij pre-eclampsie. Helaas is het ons (nog) niet gelukt de rest van de wereld te overtuigen van deze bevindingen. Ook werden er onderzoeken met de cardiologie opgezet. Ik heb prettig samengewerkt met de cardiologen Pieter Doevendans, Ebo de Muinck en Frits Bär. In het kader van de ABPM-studie werd samenwerking aangegaan met Ad Dees, internist, uit het Ikazia Ziekenhuis in Rotterdam. Dank voor de aangeleverde patiënten. De goede samenwerking met Nijmegen, middels de persoon van Bart Veldman, leverde interessante bevindingen betreffende het ecNOS-polymorfisme én een artikel op. Ook heb ik prettig samengewerkt met de groep van Rick Grobbee en Yvonne van der Schouw uit Utrecht. Professor Redon: thank you for your willingness to share some of your DNA-samples with us.

Toen de aantallen van te genotyperen monsters in de duizenden gingen lopen werd het tijd om een eigen lab hiervoor te gaan opzetten. De analisten Michael Geurts en later ook Daniëlle Bisschops hebben dit belangrijke werk keurig gedaan. Hetzelfde lab herbergde het lab Klinische Farmacologie waar Jet Bost nauwgezet honderden monsters angiotensine I en II heeft bepaald. Alles onder leiding van Paul Schiffers. Jullie allen bedankt! 
Het opzetten van een groot databestand waarin alle data van onze onderzoeksgroep gekoppeld werden was een andere grote uitdaging. Het uiteindelijke Cardim (cardiovascular database internal medicine) is met name door onze data-typiste Stella Brand een succes geworden. Stella, ook jij wordt gekenmerkt door een tomeloze inzet en ijver, maar bovenal nauwkeurigheid. En als je denkt dat ergens een foutje gemaakt is, neem je 'gewoon' weer de hele dataset door. Ook kon ik bij herhaling aankomen met weer een nieuwe deadline die gisteren reeds verlopen was. Veel van de data in dit proefschrift zijn mede door jouw werk onttrokken uit stoffige klappers en succesvol gekoppeld aan de nieuwste verkregen data. Heel veel dank daarvoor.

De infusiestudies werden verricht op het Circulatielaboratorium door Monique Fuss. Monique, jij zag me als studentje komen, nu alweer 10 jaar geleden. Weer zo één die komt en gaat' dacht je misschien, maar ik bleef hangen. Jouw jarenlange ervaring met vooral klaringsstudies waren een belangrijke constante factor. Wat ik altijd in jou gewaardeerd heb is dat je duidelijk laat merken als je het ergens niet mee eens bent. Een eigenschap die ik zeer kan waarderen. Waar je ook bij herhaling duidelijk in was, is mijn toekomst. Volgens jou is er goud te verdienen met een commercieel cardiovasculair kliniekje net over de grens op Duits grondgebied. Als mede-aandeelhouder zag je dit wel zitten. Ik vrees voor je dat ik dit nog even wil uitstellen.

Mijn collega-onderzoekers Esther Beeks, Kim van der Zander, Thomas Wierema, Marieke van Onna, Sergio Rodríguez, Marrigje Nabuurs en Claudia de Haan dank ik voor de prettige en gezellige samenwerking. Een aantal is reeds gepromoveerd, van de rest komen de boekjes op korte termijn af. Esther: wij hebben veel kamers door de gebouwen heen gedeeld en doordat een aantal onderzoeken in elkaar overliepen veel samengewerkt. Frustraties deelden we ook gezamenlijk, maar gelukkig: gedeelde smart is halve smart. Ik wens je veel succes met je laatste loodjes. Claudia: jij zag jezelf niet zo als collega-onderzoeker ('oh dat onderzoek, ik zie wel'), maar was de drijvende kracht achter het Circulatielab. Je bent een fantastische regelaar en dacht altijd actief mee hoe mijn onderzoeken ingepast en uitgevoerd konden worden op het Circulatielab. Ook buiten het werk is er een vriendschappelijk contact ontstaan. Ik waardeer het dat je je organisatorische talenten tot het einde toe hebt willen gebruiken door mijn paranymf te zijn.

De overige collega's van het lab, Dorien Bleeker en Boy Houben, dank ik voor het verrichten van diverse hand- en spandiensten. Monique Lahaye, dank voor de secretariële ondersteuning.

Tiny Wouters: geroemd in al vele dankwoorden. Nu ik zelf met je heb samengewerkt kan ik de lofzang alleen maar bevestigen. Je bent een noeste werker en offerde veel vrije tijd (zelfs vakantie!) ten behoeve van de layout van mijn proefschrift op. Een prettige bijkomstigheid is dat je net zo'n perfectionist bent als ik en dat maakt samenwerken prettig! Veel dank. 
Dank ook aan leden van de beoordelingscommissie onder voorzitterschap van Prof.dr. Struijker Boudier. Met name ook dank aan de externe leden van de commissie, Prof.dr. Navis en Prof.dr. Danser, beiden met een indrukwekkende staat van dienst in het onderzoeksveld van genetische polymorfismen van het renine-angiotensine systeem. Met Prof.dr. Vlietinck en Prof.dr. Daemen heb ik al prettig mogen samenwerken. Ik ben blij dat $\mathrm{u}$ beiden zitting hebt willen nemen in de commissie.

Dan mijn copromotor en promotor. Bram Kroon, als copromotor was je direct betrokken en verantwoordelijk voor het onderzoek. Onze gezamenlijke toevoeging aan de onderzoeksgroep van Peter was het begin van het genetisch onderzoek binnen deze groep. Samen hebben we veel verschillende onderzoekslijnen op- en uitgebouwd. Ik ben blij dat je me de ruimte gaf dingen op te zetten, maar me er tevens op wees dat het proefschrift niet te veel ondergesneeuwd mocht worden. Ik heb prettig met je samengewerkt en kijk uit naar mijn komende opleiding binnen het aandachtsgebied Vasculaire Geneeskunde. Peter de Leeuw, jij bent de beste promotor die een promovendus zich kan wensen. Je bent meer dan de promotor die op afstand de voortgang van het onderzoek volgt. Je bent betrokken, enthousiast en laagdrempelig. Altijd als ik gefrustreerd raakte door bepaalde onderzoeksuitkomsten of door de zoveelste 'onterechte' afwijzing van een artikel wist jij door een paar simpele, geniale vourscenterrum ut udta eens zo te anaiyseren br eeen en andèr 'zo te tórmuieren' mij weer hoop te geven. Met veel plezier kijk ik terug naar de twee schrijfweken die we in je buitenverblijf in de Ardèche hebben doorgebracht: de perfecte balans tussen ideaal klimaat, wetenschappelijke produktie, de 'cuisine ardéchoise' en af en toe een goede greep uit je wijnkelder.

Uiteraard ook een dankwoord voor mijn ouders: jullie hebben me altijd alle kansen geboden om me te ontwikkelen. Dat dit boekje uiteindelijk tot stand is gekomen is mede jullie resultaat. Ik hoop dat we nog lang in goede gezondheid met elkaar mogen doorbrengen.

Lieve Helga, aan jou draag ik dit boekwerk op. Als iemand mijn oprechte dank verdiend ben jij het wel. Al die jaren met een partner grotendeels werkend op afstand van huis, deadline na deadline, en veel gezamenlijke vrije tijd die opgeofferd werd ten behoeve van het proefschrift: jij hebt het allemaal doorstaan. Fantastisch en bewijzend dat onze band sterk is. Na deze moeilijke jaren gaan we het straks zeker rustiger krijgen met Ruben en ons aanstaand kindje.

Lieve Ruben, jij bent het mooiste wat me in mijn leven is overkomen en nog elke dag overkomt, mijn achilleshiel. Jouw aanwezigheid maakt al het andere relatief. Ik zie uit naar al de dingen die we samen nog gaan beleven. Als eerste binnenkort een broertje..., of een zusje! 
List of publications 


\section{List of publications}

Cornelussen R, Spiering W, Webers JHG, De Bruin LG, Reneman RS, Van der Vusse GJ, Snoeckx LHEH. Heat-shock improves the ischemia tolerance of hypertrophied rat hearts. Am J Physiol 1994;267:H1941-7.

Spiering W, Christiaans MHL, de Leeuw PW, van Hooff JP. Influence of ACE inhibition on haemoglobin and haematocrit in essential hypertensive patients. Nephrol Dial Transplant 1995;10:1254.

Spiering W, van Es PN, de Leeuw PW. Comparison of impedance cardiography and dye dilution method for measuring cardiac output. Heart 1998;79:437-41.

Spiering W, Kroon AA, Vreugdenhil HAE, Geraedts JPM, Daemen MJAP, de Leeuw PW. Samenhang tussen genetische polymorfismen en ziekte geillustreerd aan het renine-angiotensine-aldosteronsysteem en cardiovasculaire aandoeningen. Ned Tijdschr Geneeskd 1998;142:1445-50.

Krekels MME, Spiering W, Schaper NC, Houben AJHM, de Leeuw PW. Dissociation between the renal effects of angiotensin I and II in sodium-restricted normal subjects. Cardiovasc Res 1998;38:215-20.

Spiering W, Kroon AA, Fuss-Lejeune MM, Daemen MJ, de Leeuw PW. Angiotensin II sensitivity is associated with the angiotensin $\|$ type 1 receptor $A^{1166} \mathrm{C}$ polymorphism in essential hypertensives on a high sodium diet. Hypertension 2000;36:411-6.

Doevendans PA, Jukema W, Spiering W, Defesche JC, Kastelein JJ. Molecular genetics and gene expression in atherosclerosis. Int J Cardiol 2001;80:161-72.

Kroon AA, Spiering W, de Leeuw PW. Genetics in hypertension. In: Doevendans PA, Wilde AAM, eds. Cardiovascular genetics for clinicians. Dordrecht: Kluwer Academic Publishers; 2001:35-49.

Veldman BA, Spiering W, Doevendans PA, Vervoort G, Kroon AA, de Leeuw PW, Smits P. The Glu298Asp polymorphism of the NOS 3 gene as a determinant of the baseline production of nitric oxide. J Hypertens 2002;20:2023-7. 
Henskens LH, Spiering W, Stoffers HE, Soomers FL, Vlietinck RF, de Leeuw PW, Kroon AA. Effects of ACE I/D and AT1R-A1166C polymorphisms on blood pressure in a healthy normotensive primary care population: first results of the Hippocates study. J Hypertens 2003;21:81-6.

Spiering W, de Leeuw PW. Genetische aspecten van hypertensie. In: Birkenhäger WH, de Leeuw PW, eds. Handboek hypertensie. Utrecht: De Tijdstroom; 2003: 145-55.

Spiering W, Kroon AA, de Leeuw PW. Genetics in hypertension. To be published in Sem Vasc Med.

Spiering W, Rodríguez Hernández SA, Kroon AA, Zwaan IM, de Leeuw PW. Genetic influences on twenty-four hour blood pressure profiles in a hypertensive population. Submitted.

Spiering W, Schiffers PM, Kroon AA, de Leeuw PW. Slow angiotensin-converting enzyme-related conversion of angiotensin I in plasma of hypertensive patients: relationship with the angiotensin-converting enzyme insertion/deletion polymorphism. Submitted.

Spiering W, Kroon AA, de Leeuw PW. Genetic aspects of renal function in essential hypertension. Submitted.

Spiering W, Kroon AA, Fuss-Lejeune MJ, Schiffers PM, de Leeuw PW. Genetic contribution to the acute effects of angiotensin II type 1 receptor blockade. Submitted.

Spiering W, Henskens LH, Kroon AA, Stoffers HE, de Leeuw PW. Genetic contribution to the chronic effects of angiotensin II type 1 receptor blockade. Submitted. 
Curriculum vitae 


\section{Curriculum vitae}

Wilko Spiering werd op 23 oktober 1971 in Arnhem geboren. In 1990 behaalde hij het WWO diploma aan het Christelijk Lyceum te Arnhem. Datzelfde jaar werd gestart met de studie geneeskunde aan de Rijksuniversiteit Limburg te Maastricht, waar hij in 1995 het doctoraalexamen (met genoegen) en in 1997 het artsexamen (met genoegen) behaalde. Tijdens de studie werden studentassistentschappen gelopen op de afdelingen Fysiologie (Prof.dr. L.H.E.H. Snoeckx) en Interne Geneeskunde (Prof.dr. J.P. van Hooff en Prof.dr. P.W. de Leeuw). Van 1997 tot 2000 was hij Assistent In Opleiding (AIO) aan de vakgroep Interne Geneeskunde, Cardiovascular Research Institute Maastricht (CARIM), Universiteit Maastricht onder leiding van Dr. A.A. Kroon en Prof.dr. P.W. de Leeuw. Van 2000 tot 2001 was hij medisch coördinator van het onderzoeksproject Hypertensie en Cognitie van de vakgroepen Interne Geneeskunde en Neuropsychologie van het Academisch Ziekenhuis Maastricht (Prof.dr. P.W. de Leeuw en Dr. M.P.J. van Boxtel). In april 2001 werd begonnen met de opleiding Interne Geneeskunde in het Academisch Ziekenhuis Maastricht (opleider Prof.dr. H.F.P. Hillen). Sinds 1 oktober 2003 wordt zijn opleiding voortgezet in het Catharina-ziekenhuis Eindhoven (opleider Dr. B. Bravenboer). Per 1 april 2005 zal hij starten met het aandachtsgebied Vasculaire Geneeskunde. Hij is getrouwd met Helga Fokkema en samen hebben zij 1 zoon: Ruben. 


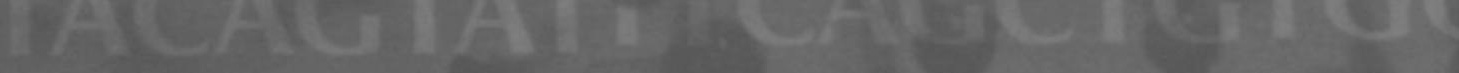

